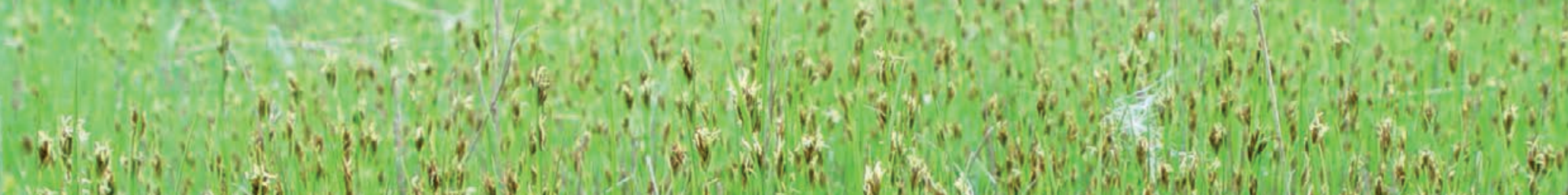

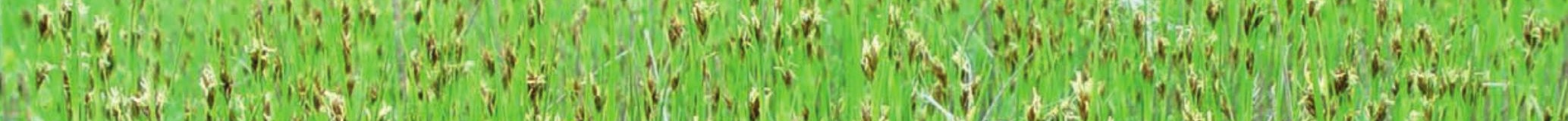

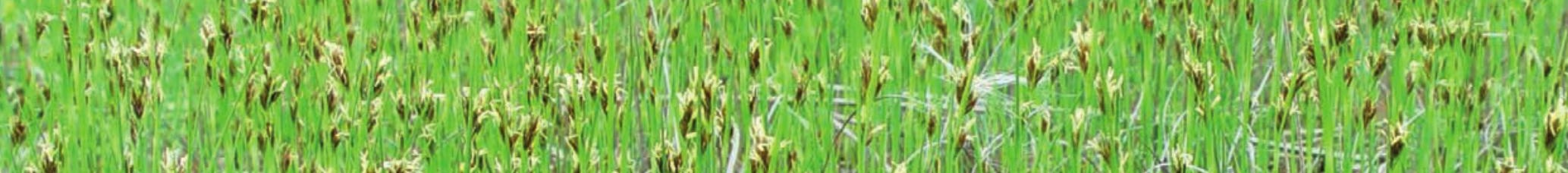

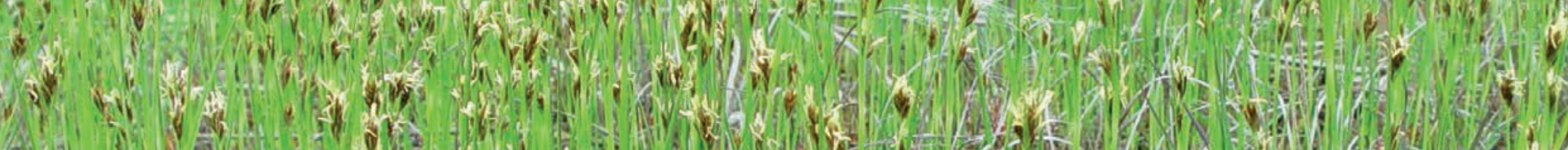
ave 5. E.
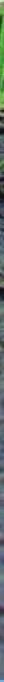

\title{
Relaties tussen de hoeveelheid stikstofdepositie en de kwaliteit van habitattypen
}

G.W.W. Wamelink, P.W. Goedhart, H.D. Roelofsen, R. Bobbink, M. Posch, H.F. van Dobben \& Data providers 



\section{Relaties tussen de hoeveelheid stikstofdepositie en de kwaliteit van habitattypen}

G.W.W. Wamelink ${ }^{1}$, P.W. Goedhart ${ }^{2}$, H.D. Roelofsen ${ }^{1}$, R. Bobbink ${ }^{3}$, M. Posch ${ }^{4}$, H.F. van Dobben ${ }^{1}$ \& Data providers $^{5}$

1 Wageningen Environmental Research, Wageningen University \& Research, Wageningen, The Netherlands

2 Biometris, Wageningen University \& Research, Wageningen, The Netherlands

3 B-WARE Research Centre, Radboud University, Nijmegen, The Netherlands

4 International Institute for Applied Systems Analysis, Pollution Management Research Group, Laxenburg, Austria

5 Dataproviders http://euroveg.org/eva-database en Bijlage 1

Dit onderzoek is uitgevoerd door Wageningen Environmental Research en gesubsidieerd door het ministerie van Landbouw, Natuur en Voedselkwaliteit, in het kader van het Beleidsondersteunend onderzoekthema 'Ecologische basiskwaliteit Land' (projectnummer BO-43-021.01-022).

Wageningen Environmental Research

Wageningen, mei 2021

Gereviewd door:

Prof Dr. W. de Vries

Ir. F. van der Zee

Ir. T. Hermans

Akkoord voor publicatie:

Dr. J.C. de Jong, Biodiversiteit \& Beleid
Rapport 3089

ISSN 1566-7197

ISBN 978-94-6395-836-3 
Wamelink, G.W.W., P.W. Goedhart, H.D. Roelofsen, R. Bobbink, H.F. van Dobben \& Data providers, 2021. Relaties tussen de hoeveelheid stikstofdepositie en de kwaliteit van habitattypen. Wageningen, Wageningen Environmental Research, Rapport 3089. 152 blz.; 67 fig.; 15 tab.; 55 ref.

Stikstofdepositie beïnvloedt in hoge mate de kwaliteit van habitattypen. Om te bepalen vanaf welke stikstofdepositie de kwaliteit van de habitattypen significant afneemt, zijn kritische depositiewaarden opgesteld. Om te bepalen in welke mate de kwaliteit afneemt bij stikstofdeposities hoger dan de kritische depositiewaarde, zijn er in dit onderzoek dosis-effectrelaties opgesteld. Dat is enerzijds gedaan op basis van empirische gradiëntstudies en anderzijds is verkend in hoeverre dat ook kan op basis van statistische relaties tussen het voorkomen van kwalificerende soorten van habitattypen en stikstofdepositie, waarbij ook is gekeken naar de respons van verdringingssoorten. Het aantal dosiseffectrelaties op basis van empirische studies is beperkt door gebrek aan data, maar wel zeer veelbelovend. Op basis van statistische relaties kon voor 60 van de 61 habitat(sub)typen een responscurve worden geschat. In vergelijking met de empirische relaties komen de statistische relaties voor een deel goed overeen en voor een klein deel slecht.

Nitrogen deposition is influencing the quality of Habitat types. To assess at what deposition level the quality is influenced significantly critical loads have been estimated. To estimate the extent of the quality loss we estimated doses-response curves for nitrogen deposition per habitat type. This was done by collecting field data from empirical gradient studies and by estimating response curves for habitat types based on response curves of qualifying species per habitat type. The latter also includes a study to the response of so-called displacement species. The number of empirical studies is very limited but the results from the view that are available are very promising. Statistical relations could be estimated for 60 out of 61 nitrogen deposition sensitive habitat types occurring in the Netherlands. Comparison between the empirical and statistical relations showed that they showed very similar responses for part of the habitat types and no relation for a minor part of the types.

Trefwoorden: stikstof, habitattype, ammoniak, stikstofoxiden, biodiversiteit, responscurven, gradiënt studies

Dit rapport is gratis te downloaden van https://doi.org/10.18174/547752 of op www.wur.nl/environmental-research (ga naar 'Wageningen Environmental Research' in de grijze balk onderaan). Wageningen Environmental Research verstrekt geen gedrukte exemplaren van rapporten.

(C) 2021 Wageningen Environmental Research (instituut binnen de rechtspersoon Stichting Wageningen Research), Postbus 47, 6700 AA Wageningen, T 03174807 00, www.wur.nl/environmental-research. Wageningen Environmental Research is onderdeel van Wageningen University \& Research.

- Overname, verveelvoudiging of openbaarmaking van deze uitgave is toegestaan mits met duidelijke bronvermelding.

- Overname, verveelvoudiging of openbaarmaking is niet toegestaan voor commerciële doeleinden en/of geldelijk gewin.

- Overname, verveelvoudiging of openbaarmaking is niet toegestaan voor die gedeelten van deze uitgave waarvan duidelijk is dat de auteursrechten liggen bij derden en/of zijn voorbehouden.

Wageningen Environmental Research aanvaardt geen aansprakelijkheid voor eventuele schade voortvloeiend uit het gebruik van de resultaten van dit onderzoek of de toepassing van de adviezen.

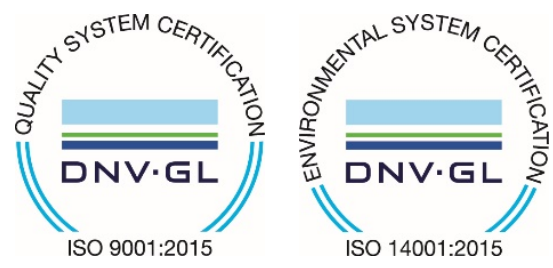

Wageningen Environmental Research werkt sinds 2003 met een ISO 9001 gecertificeerd kwaliteitsmanagementsysteem. In 2006 heeft Wageningen Environmental Research een milieuzorgsysteem geïmplementeerd, gecertificeerd volgens de norm ISO 14001.

Wageningen Environmental Research geeft via ISO 26000 invulling aan haar maatschappelijke verantwoordelijkheid.

Wageningen Environmental Research Rapport 3089 | ISSN 1566-7197

Foto omslag: Wieger Wamelink 


\section{Inhoud}

$\begin{array}{ll}\text { Verantwoording } & 5\end{array}$

$\begin{array}{ll}\text { Samenvatting } & 7\end{array}$

$\begin{array}{ll}\text { Aanleiding en probleemstelling } & 11\end{array}$

A Empirisch bepaalde relaties tussen de hoeveelheid stikstofdepositie en $\begin{array}{ll}\text { de kwaliteit van habitattypen } & 15\end{array}$

$\begin{array}{lll}\text { A.1 Inleiding } & 15\end{array}$

$\begin{array}{lll}\text { A. } 2 \text { Methodiek } & 16\end{array}$

$\begin{array}{lll}\text { A.3 Resultaten } & 17\end{array}$

$\begin{array}{lll}\text { A.3.1 Droge duingraslanden (Grijze duinen) } & 17\end{array}$

$\begin{array}{lll}\text { A.3.2 Droge heiden } & 19\end{array}$

A.3.3 Intermezzo: het belang van waarnemingen bij zeer lage
stikstofdepositie

$\begin{array}{lll}\text { A.3.4 Kalkgraslanden } & 22\end{array}$

A.3.5 Heischrale graslanden $\quad 25$

A.3.6 Montane graslanden $\quad 26$

$\begin{array}{ll}\text { A.3.7 Hoogvenen } & 29\end{array}$

$\begin{array}{lll}\text { A.3.8 Atlantische eikenbossen } & 31\end{array}$

A.4 Discussie en conclusies $\quad 32$

B Een verkenning van de statistische relatie tussen de hoeveelheid stikstofdepositie en de kwaliteit van habitattypen $\quad 35$

B.1 Inleiding $\quad 35$

B.2 Responscurven voor habitattypen op basis van kwalificerende soorten 36

B.2.1 Materiaal en methoden voor het afleiden van responscurven 36

B.2.2 Resultaten responscurven op basis van kwalificerende soorten 56

B.2.3 Discussie 73

B.3 Responscurven voor habitattypen op basis van verdringingssoorten $\quad 82$

B.3.1 Materiaal en methoden $\quad 82$

B.3.2 Resultaten responscurven op basis van verdringingssoorten 84

B.3.3 Discussie 99

B.4 Betrouwbaarheid van de geschatte responscurven 99

$\begin{array}{lll}\text { B.4.1 Data } & 99\end{array}$

B.4.2 Methodiek: Koppeling van soorten aan habitattypen, EUNIS-

typen en structuurtypen 100

C Integratie van empirische en statistische relaties $\quad 102$

$\begin{array}{lll}\text { C.1 Inleiding } & 102\end{array}$

$\begin{array}{ll}\text { C.2 Methode } & 102\end{array}$

$\begin{array}{lll}\text { C.3 Resultaten } & 103\end{array}$

C.4 Beoordeling van de integratie 113

$\begin{array}{ll}\text { Literatuur } & 117\end{array}$

Bijlage 1 Data Leveranciers uit de EVA-database 120

Bijlage 2 Indeling van habitattypen in structuurtypen en ruwheid 122

Bijlage 3 Koppeling van EUNIS-typen aan structuurtypen en ruwheid 124

Bijlage 4 EUNIS-typen waarvoor de vertaling naar structuurtype niet eenduidig is 
Bijlage 7 Onderbouwing van gemaakte keuzes bij het bepalen van de responscurven voor habitattypen

Bijlage 8 Responscurven voor habitattypen en onderliggende kwalificerende soorten per set van covariabelen

Bijlage 9 Python-programma en procesrapport voor het koppelen van EVA-database met covariabelen

Bijlage 10 Genstat-programma voor het schatten van responscurven 


\section{Verantwoording}

Rapport: 3089

Projectnummer: 5200045270-DOREN 2019

Wageningen Environmental Research (WENR) hecht grote waarde aan de kwaliteit van zijn eindproducten. Een review van de rapporten op wetenschappelijke kwaliteit door een referent maakt standaard onderdeel uit van ons kwaliteitsbeleid.

Akkoord Referent die het rapport heeft beoordeeld,

functie: Hoogleraar \& senior onderzoeker

naam: $\quad$ Prof. Dr. W. de Vries

datum: 11-05-2021

functie: Senior onderzoeker

naam: Ir. F. van der Zee

datum: $\quad$ 12-05-2021

functie: Senior onderzoeker

naam: Ir. T. Hermans

datum: 21-05-2021

Akkoord teamleider voor de inhoud,

naam: Dr. J.C. de Jong, Biodiversiteit \& Beleid

datum: 22-05-2021 


\section{Samenvatting}

Stikstofdepositie is een belangrijke oorzaak achter twee van de grotere zogenaamde 'ver'-thema's die de Nederlandse biodiversiteit bedreigen: vermesting (eutrofiëring) en verzuring. Tot nu toe is de aandacht sterk gericht geweest op het bepalen van het niveau waarboven schadelijke effecten gaan optreden: de kritische depositiewaarden (KDW's). Er is geen overzicht gepubliceerd van de mate van effect in relatie tot de mate van overschrijding van die KDW's. Er is behoefte aan het nader kwantificeren van de relatie tussen stikstofdepositie en de kwaliteit van habitattypen. Op basis van een dergelijke relatie kan een inschatting gemaakt worden of een bepaalde toe- of afname in de stikstofdepositie een groot of een klein (potentieel) effect heeft op de kwaliteit van habitattypen.

In dit rapport worden twee manieren gepresenteerd om de dosis-effectrelaties voor habitattypen te bepalen. Deze twee manieren zijn gepresenteerd in de delen A en B.

In Deel $A$ is gebruikgemaakt van empirische gradiëntstudies, waarin gebieden met eenzelfde habitattype maar een verschillende stikstofdepositie direct met elkaar worden vergeleken. Daarbij is de kwaliteit afgezet tegen een gradiënt van stikstofdepositie. De gegevens zijn afkomstig uit onderzoek dat is uitgevoerd in meerdere Europese landen. Het aantal studies is echter beperkt (7 typen).

Er bleken analyses mogelijk voor vijf hoofdgroepen van ecosystemen: kustvegetaties, heiden, graslanden, venen en bossen. De volgende conclusies konden worden getrokken:

- In alle gradiëntstudies werd een negatieve correlatie gevonden tussen soortenrijkdom en/of soortensamenstelling van de vegetatie en stikstofdepositie.

- In hoeverre stikstofdepositie specifiek voor kenmerkende soorten van habitattypen een bedreiging vormt, is in de gradiëntstudies vaak niet of op een indirecte wijze onderzocht. In alle studies is het effect op de totale soortenrijkdom bepaald. Dat levert meestal, maar niet altijd, een negatief verband op. Vooral bij van nature al relatief soortenarme typen is het verband niet (of minder) duidelijk. Het duidelijkst is het effect bij de soorten die juist het afhankelijkst zijn van de omstandigheden die karakteristiek zijn voor het betreffende habitattype. Door alleen te kijken naar de totale soortenrijkdom worden de relevantste effecten van stikstofdepositie dus gemaskeerd, namelijk de vervanging van kenmerkende soorten door algemene soorten die zijn aangepast aan stikstofrijke omstandigheden.

- De effecten van stikstofdepositie zijn sterker bij de heischrale graslanden (H6230), die voorkomen op zwak gebufferde bodems, dan bij kalkgraslanden (H6210), die door de bufferende werking van de kalkrijke bodem vrijwel niet gevoelig zijn voor bodemverzuring.

- Bij meerdere habitattypen blijkt al direct boven de KDW een scherpe terugval plaats te vinden in kwaliteit. In enkele gevallen kon dat alleen maar worden aangetoond doordat ook locaties waren bestudeerd met zeer lage stikstofdepositie (2-5 kg N/ha/jr).

In Deel B is verkend in hoeverre dosis-effectrelaties voor habitattypen kunnen worden bepaald op basis van statistische relaties tussen het voorkomen van kwalificerende soorten van habitattypen en stikstofdepositie, waarbij ook is gekeken naar de respons van verdringingssoorten.

Om een relatie te leggen tussen de kwaliteit van habitattypen en stikstofdepositie, zijn voor dit onderzoek soorten geselecteerd die kenmerkend (diagnostisch) zijn voor de plantengemeenschappen met een goede kwaliteit van een bepaald habitat(sub)type en die het verschil aangeven met plantengemeenschappen die niet behoren tot de goede kwaliteit van het habitat(sub)type. Onderdeel van deze 'kwalificerende soorten' zijn ook de typische soorten die reeds formeel voor de habitattypen zijn geselecteerd. De responscurven per kwalificerende soort, te weten de kans op voorkomen van een soort in relatie tot de stikstofdepositie, zijn geschat op basis van het wel of niet voorkomen van soorten in vegetatieopnamen uit de 'European Vegetation Archive' (EVA) database. Daarbij zijn alleen opnamen gebruikt uit de Atlantische zone en omringende gebieden. Deze inperking voorkomt dat 
opnamen met totaal andere klimatologische of abiotische omstandigheden de respons meebepalen. Tevens zijn alleen opnamen beneden de $500 \mathrm{~m}$ hoogte gebruikt om zo veel mogelijk aan te sluiten op de Nederlandse situatie. Aan elke opname is de gemiddelde temperatuur, regenval én een geaggregeerd bodemtype (World Reference Base for Soil Resources) toegekend. De stikstofdepositie $\left(\mathrm{NO}_{\mathrm{x}}+\mathrm{NH}_{\mathrm{y}}\right)$ van een opname is gebaseerd op een nieuw ontwikkelde rekenmethode waarbij gebruik is gemaakt van resultaten van het EMEP-model (European Monitoring and Evaluation Programme). Op basis van deze gegevens is voor elke soort in een habitattype een responscurve voor stikstofdepositie geschat, waarbij gecorrigeerd wordt voor de covariabelen temperatuur, neerslag en bodemtype. Daarbij zijn alleen opnamen gebruikt in het geschatte verspreidingsgebied van de soort, dat bestaat uit de samengevoegde cirkels met een straal van $25 \mathrm{~km}$ rond opnamen waar de soort voorkomt. Deze set van opnamen is verder ingeperkt door alleen opnamen te kiezen die behoren tot het structuurtype dat toegekend is aan het habitattype. Hiermee is bijvoorbeeld voorkomen dat opnamen in bossen worden meegenomen voor het berekenen van de kans op het voorkomen van een graslandsoort.

De responscurve voor een habitattype in Nederland is berekend als het gemiddelde van genormaliseerde responscurven van de bij het habitattype behorende kwalificerende soorten op basis van een gelijk oppervlak voor elke soort onder de responscurve. De normalisatie geeft de soorten een gelijk gewicht en voorkomt dat het gemiddelde gedomineerd wordt door de meer algemene soorten met een grotere kans op voorkomen.

Voor 60 van de 61 onderzochte habitattypen konden responscurven worden geschat. Per responscurve is een voorlopig oordeel gegeven over de plausibiliteit, aangegeven als goed, matig en slecht. Bij een groot aantal typen was het oordeel goed, maar bij verscheidene typen was het oordeel matig of slecht om nu al te kunnen spreken van een over-all betrouwbare methode om dosis-effectrelaties mee te kunnen bepalen. Er is nader onderzoek nodig om te bepalen welke mogelijke (systematische) fouten er zijn opgetreden in de bewerking van de gegevens.

In aanvulling op de responscurven voor de kans op voorkomen van kwalificerende soorten zijn ook responscurven afgeleid voor de bedekkingsgraad van (potentiële) verdringingssoorten: plantensoorten die reageren op stikstofdepositie door zodanig sterk toe te nemen in bedekking dat andere soorten (met name kwalificerende soorten) daardoor worden verdrongen en (dreigen te) verdwijnen. In dit onderdeel is per responscurve een oordeel gegeven over de plausibiliteit, aangegeven als goed, matig en slecht, waarbij er een gemengd beeld aanwezig is. Het is nodig om nader onderzoek te doen, zodat in de toekomst voldoende betrouwbare uitspraken gedaan kunnen worden over de toename van verdringingssoorten in alle habitattypen waarin het proces van verdringing (zoals vergrassing en verruiging) zich voordoet.

Op basis van de vergelijking van de responscurven voor habitattypen met (1) responscurven uit empirische veldstudies en (2) de berekende KDW van de Nederlandse habitattypen, werden 37 van de 60 afgeleide responscurven voldoende betrouwbaar geacht om nader te duiden wat er gebeurt rond en voorbij de KDW. 8 curven zijn als matig beoordeeld en voor 15 habitattypen is de responscurve niet bruikbaar. Nader onderzoek naar verbeteringen van alle responscurven en verdere verzameling van veldgegevens is noodzakelijk om meer inzicht en betrouwbaarheid te krijgen in de relatie tussen stikstofdepositie en de kwaliteit van habitattypen.

In Deel C zijn de responscurven uit Deel B gevalideerd met de empirische relaties uit Deel A. Voor de meeste typen, maar niet voor alle, is er een goede overeenkomst. Dat geeft aanleiding om, ondanks de geconstateerde problemen in de verkenning van Deel $B$, in vervolgonderzoek nader te onderzoeken hoe dosis-effectrelaties kunnen worden bepaald op basis van statistische relaties. Want hoe betrouwbaar de uitkomsten van empirische gradiëntstudies ook zijn, het aantal habitattypen waarvoor die studies zijn uitgevoerd is te beperkt om daarmee uitspraken te doen over álle stikstofgevoelige habitattypen, zo bleek uit Deel A. Een verbetering van de methode zoals nu verkend in Deel B zou voor zo'n noodzakelijke verbreding kunnen zorgen. 


\section{Begrippen en definities}

\section{Empirische KDW}

Kritische Depositie Waarde die is opgesteld op basis van veldwaarnemingen, zoals stikstofadditieexperimenten.

\section{EUNIS}

European Nature Information System. Een vegetatieclassificatiesysteem op Europese schaal.

\section{Gemodelleerde KDW}

Kritische Depositie Waarde die is afgeleid met behulp van een rekenmodel dat kwantitatieve beschrijvingen bevat van processen in bodem en vegetatie die een rol spelen bij het tot stand komen van het effect van stikstof (Van Dobben et al., 2012).

\section{Habitattype}

Natuurlijk of halfnatuurlijk ecosysteem dat van communautair belang is en daarom op Bijlage 1 van de Habitatrichtlijn staat. Elk habitattype is in een profiel gedefinieerd (Anonymus, 2014) op basis van met name plantengemeenschappen (vegetatietypen). De kwaliteit ervan bestaat, naast die plantengemeenschappen, o.a. uit typische plantensoorten. Habitattypen kunnen uit meerdere subtypen bestaan.

\section{Kritische Depositie Waarde (KDW)}

De grens waarboven het risico bestaat dat de kwaliteit van de habitat significant wordt aangetast als gevolg van de verzurende en/of vermestende invloed van atmosferische stikstofdepositie (Van Dobben et al., 2012).

\section{Kwalificerende soorten}

Soorten die diagnostisch zijn voor de plantengemeenschappen met een goede kwaliteit van een bepaald habitat(sub)type en die dus het verschil aangeven met plantengemeenschappen die niet behoren tot de goede kwaliteit van het habitat(sub)type). Deze soorten zijn geselecteerd aan de hand van een bepaald niveau van trouw en presentie. Dit kunnen zowel algemene als zeldzame soorten zijn. Ook alle typische soorten zijn hiertoe gerekend.

\section{Landcodes}

Voor een aantal resultaten wordt gebruikgemaakt van onderstaande landcodes: Nederland (NLD), Denemarken (DNK), Frankrijk (FRA), Duitsland (DEU), Groot-Brittannië (GBR), Ierland (IRL), Zweden (SWE), België (BEL), Oostenrijk (AUT), Spanje (ESP), Zwitserland (CHE), Finland (FIN), Noorwegen (NOR), Luxemburg (LUX), Portugal (PRT), Liechtenstein (LIE).

\section{Responscurve}

Een curve die de relatie tussen twee variabelen legt. In dit onderzoek de stikstofdepositie (verklarende variabele) gerelateerd aan óf de (genormaliseerde) kans op voorkomen van een soort (voor kwalificerende soorten) óf het percentage bedekking van een soort (voor verdringingssoorten).

\section{Selectiegebied}

Geografische gebied waaruit vegetatieopnamen zijn geselecteerd voor dit onderzoek.

\section{Stikstofdepositie}

De hoeveelheid stikstofhoudende verbindingen $\left(\mathrm{NO}_{x}\right.$ en $\left.\mathrm{NH}_{\mathrm{y}}\right)$ die vanuit de atmosfeer neerslaan op vegetatie, bodem en oppervlaktewater, in de vorm van droge depositie (stof) of natte depositie (neerslag). In dit onderzoek is gewerkt met de totale stikstofdepositie: de som van $\mathrm{NO}_{x}$ en $\mathrm{NH}_{\mathrm{y}}$ uit natte en droge depositie.

\section{Structuurtype of vegetatiestructuurtype}

Type gekenmerkt door een combinatie van een bepaalde vegetatiestructuur en een bepaald vocht- en zoutgehalte van de bodem. De typen zijn voor dit onderzoek gedefinieerd en vertaald naar EUNIStypen en habitattypen. 
Typische soorten

Soorten die mede de kwaliteit bepalen van habitattypen (Anonymus, 2014).

Verdringingssoort

Plantensoort die reageert op stikstofdepositie door zodanig sterk toe te nemen in bedekking dat andere soorten (met name kwalificerende soorten) daardoor worden verdrongen en (dreigen te) verdwijnen. Een verdringingssoort kan een type-eigen soort zijn, dus zelf een kwalificerende soort, of een type-vreemde soort (in het laatste geval is er dus eerst vestiging nodig voordat van toename in bedekking sprake kan zijn). Voor dit rapport zijn verdringingssoorten geselecteerd uit de soortgroepen vaatplanten (inclusief bomen), mossen en korstmossen. 


\section{Aanleiding en probleemstelling}

Stikstofdepositie is een belangrijke oorzaak achter twee van de grotere zogenaamde 'ver'-thema's die de Nederlandse biodiversiteit bedreigen: vermesting (eutrofiëring) en verzuring. Tot nu toe is de aandacht sterk gericht geweest op het bepalen van het niveau waarboven schadelijke effecten gaan optreden: de kritische depositiewaarden (KDW's). Er is nog geen overzicht gepubliceerd van de mate van effect in relatie tot de mate van overschrijding van die KDW's. Er is behoefte aan het nader kwantificeren van de relatie tussen stikstofdepositie en de kwaliteit van habitattypen. Op basis van een dergelijke relatie kan een inschatting gemaakt worden of een bepaalde toe- of afname in de stikstofdepositie een groot of een klein (potentieel) effect heeft op de kwaliteit van habitattypen.

Om inzichtelijk te maken vanaf welk niveau van depositie negatieve effecten op habitattypen optreden, zijn de kritische depositiewaarden voor stikstof opgesteld. Op Europees niveau zijn deze gepubliceerd in Bobbink \& Hettelingh (2011) en voor Nederland in Van Dobben et al. (2012), een actualisatie van Van Dobben \& Hinsberg (2008). In Van Dobben et al. (2012) wordt de KDW gedefinieerd als: "de grens waarboven het risico bestaat dat de kwaliteit van het habitat significant wordt aangetast als gevolg van de verzurende en/of vermestende invloed van atmosferische stikstofdepositie." De in Nederland gebruikte KDW's zijn gebaseerd op een combinatie van empirische studies en modelstudies. De relatie tussen stikstofdepositie en het al dan niet duurzaam voorkomen van vegetatietypen en habitattypen, die ten grondslag ligt aan het bepalen van kritische depositiewaarden, is onder andere bevestigd door Wilkinson et al. (2016), Payne et al. (2020) en Clark et al. (2019).

Vanwege de wens om meer inzicht te krijgen in het effect van verschillende depositieniveaus op habitattypen (niet alleen het niveau van de KDW), is het nodig om dosis-effectrelaties te bepalen in de vorm van zogenoemde responscurven. Deze beschrijven op een kwantitatieve manier de relatie tussen de hoeveelheid stikstofdepositie en de kwaliteit van habitattypen voor de hele range van stikstofdepositie. Om die dosis-effectrelaties te kunnen bepalen, is het nodig om gegevens te hebben over enerzijds de verschillende niveaus van stikstofdepositie en anderzijds over de kwaliteit van de natuur. Het is belangrijk om de kwaliteit duidelijk te definiëren, zodat inzichtelijk wordt wat precies wordt bedoeld met een afname of aantasting van kwaliteit. Omdat deze studie haar aanleiding vindt in het beschermen van habitattypen (Bijlage II van de Habitatrichtlijn), wordt hier uitgegaan van de kwaliteit zoals bedoeld in het Profielendocument (Anonymus, 2014), die wat betreft de vegetatie is gebaseerd op de Vegetatie van Nederland (Schaminée et al., 1995). Indirect gaat het daardoor om het voorkomen van de kwalificerende plantensoorten van die vegetatietypen in relatie tot de hoeveelheid stikstofdepositie.

Responscurven zijn op verschillende manieren te genereren. Dat kan ten eerste op basis van velddata en (laboratorium)experimenten. Op basis van langdurige stikstofadditie-experimenten in schone gebieden met trappen van stikstoftoediening (van laag tot hoog) zijn relaties op te stellen tussen soortenrijkdom en stikstofdoses. Een goed experiment voor de hele gradiënt in stikstofdepositie kan daarom alleen worden opgezet in door stikstof (nagenoeg) niet-beïnvloede situaties. Hierbij worden elk jaar verschillende hoeveelheden stikstof als depositie toegediend, waarna de effecten op de vegetatie (en bodem) worden onderzocht. Deze experimenten moeten langdurig plaatsvinden en zijn daarom kostbaar. De veldsituatie kan ook gesimuleerd worden onder gecontroleerde omstandigheden in het laboratorium. Dit heeft als voordeel dat geen achtergronddepositie plaatsvindt, maar als nadeel dat (in de regel) laboratoriumexperimenten relatief kortlopend zijn, waardoor langetermijneffecten niet goed kunnen worden vastgesteld. Daarnaast komen laboratoriumomstandigheden minder goed overeen met veldomstandigheden.

Een tweede mogelijkheid is het gebruikmaken van modelberekeningen, zoals is gebeurd bij het preciseren en aanvullen van de empirische KDW's in Van Dobben et al. (2012). 
Een derde mogelijkheid is het gebruikmaken van gradiëntstudies, waarin gebieden met eenzelfde habitattype, maar met een verschillende stikstofdepositie direct met elkaar worden vergeleken. Daarbij wordt de kwaliteit dus afgezet tegen een gradiënt van stikstofdepositie. Een bekend voorbeeld van zo'n gradiëntstudie is Stevens et al. (2010). Het beschikbaar komen van meerdere gradiëntstudies vormde een van de aanleidingen om dit rapport op te stellen. Een inventarisatie van gradiëntstudies is opgenomen in Deel A van dit rapport.

Een vierde mogelijkheid is het in beeld brengen van statistische relaties tussen het voorkomen van soorten van habitattypen enerzijds en de hoeveelheid stikstofdepositie anderzijds. Het verschil met de gradiëntstudies is dat niet gekeken wordt naar aantasting van een habitattype, maar dat gekeken wordt naar het voorkomen van de bij het habitattype behorende kwalificerende soorten. Dat heeft als voordeel dat gebruikgemaakt kan worden van de totale set aan relevante soorten en daarmee kan (in potentie) een responscurve worden opgesteld voor alle habitattypen, niet alleen voor de habitattypen waarvan gradiëntstudies bekend zijn. Kostbare veldexperimenten zijn dan niet nodig. Deze benadering kent ook nadelen. Er wordt namelijk op een indirecte wijze, via de samenstellende kwalificerende soorten, een uitspraak gedaan over habitattypen. Tevens geldt dat het voorkomen van soorten door veel verschillende factoren wordt bepaald, niet alleen door stikstofdepositie. Bij het opsporen van het specifieke effect van stikstofdepositie zal dus de ene factor onderscheiden moeten worden van andere factoren. Deze statistische benadering is verkend in Deel B van dit onderzoek. Dít deel is slechts een verkenning van de mogelijkheden.

Bij het schetsen van de verschillende onderzoeksmogelijkheden ligt de focus op kwaliteitsafname in de vorm van het verdwijnen van (kwalificerende) soorten. Een van de aanleidingen van dit onderzoek was echter ook de wens om meer zicht te krijgen op verruiging: het verdringen van kwetsbare soorten door concurrentiekrachtige soorten. Er zijn namelijk ook soorten die profiteren van stikstofdepositie. Zij gaan harder groeien, worden hoger en groter en concurreren zo andere soorten weg. In dit onderzoek wordt hiervoor de term verdringingssoort gebruikt. In Deel B wordt hier aandacht aan besteed. Het belang hiervan is dat verruiging eerder kan optreden dan dat de kwetsbare soorten daadwerkelijk verdwijnen. Het toenemen van verdringingssoorten kan dus indiceren voor negatieve veranderingen in een vegetatie, soms zonder dat dit al te zien is aan de afname van kwetsbare soorten.

Zoals hierboven al is aangestipt, wordt het zoeken naar verbanden tussen natuurkwaliteit en stikstofdepositie belemmerd door het feit dat in veel onderzoeken en bij veel van de beschikbare datasets sprake is van interferentie met andere (mogelijke) oorzaken van voor- of achteruitgang van habitattypen en hun kwalificerende soorten. De belangrijkste andere factoren zijn:

- Een belangrijke beperking is dat niet bekend is hoe de historische depositie zich precies heeft ontwikkeld in de loop van (soms vele) decennia. De tijdsduur van de KDW-overschrijding en de variaties daarin zijn belangrijke factoren in het vermestings- en verzuringsproces. De historische ontwikkeling is relevant, omdat stikstof zich in de bodem ophoopt en effecten uit het verleden niet zomaar teniet worden gedaan. De beschikbare gegevens betreffen veelal een momentopname of betreffen in het gunstigste geval een serie waarnemingen van meerdere jaren tot enkele decennia.

- Verzuring en vermesting kunnen ook door andere stoffen dan stikstof worden veroorzaakt. Verzuring treedt ook op door zwavel (de huidige zuurgraad is dus mede bepaald door zwaveldepositie, die in het verleden veel hoger was dan nu). Eutrofiëring treedt ook op door bijvoorbeeld fosfor of kalium (Van Dobben et al., 2017). In oppervlaktewater of grondwater gevoede habitattypen wordt stikstof ook via het water aangevoerd.

- De kwaliteit van habitattypen kan ook aangetast worden door bijvoorbeeld verdroging, versnippering en klimaatverandering.

- Aan de positieve kant speelt het beheer van de habitattypen een belangrijke rol. Instandhoudingsbeheer (met name vegetatie- en waterhuishoudkundig beheer) is erop gericht de bestaande natuurkwaliteit te handhaven. Daarbij kan stikstof uit het systeem worden verwijderd, met name door maaien en afvoeren, maar dit is niet het primaire doel. Bij het vaststellen van de $\mathrm{KDW}$ is daar overigens al rekening mee gehouden. Bij herstelbeheer is het primaire doel het herstellen van habitattypen of ten minste het tegengaan van verslechtering als gevolg van een of meer bedreigende factoren. Bij effectief herstelbeheer worden de negatieve gevolgen van stikstof zodanig opgevangen dat ze niet (of beperkt) zichtbaar zijn. Dat betekent dat een (vrij) goede 
natuurkwaliteit nog kan blijven voortbestaan bij soms ernstige overschrijding van de KDW. Hierdoor worden de effecten van stikstofdepositie gemaskeerd. Overigens kan aanvullend of geïntensiveerd beheer ook een keerzijde hebben. Het verwijderen van de opgebouwde stikstofvoorraad in de vegetatie of in de bodem kan tot gevolg hebben dat een deel van de soorten verdwijnt omdat ze niet tegen deze ingreep kunnen, de zaadbank uitgeput raakt of omdat er negatieve neveneffecten optreden ten aanzien van de mineralenbalans. Beide gevolgen van herstelbeheer (zowel de positieve als de negatieve) zijn niet te onderscheiden in de voorhanden zijnde gegevens.

\section{Projectdoelstelling en werkwijze}

Dit rapport is het resultaat van het project 'Dosis-effectrelaties stikstof'. Het doel van de studie is het bepalen van het effect van stikstofdepositie op de vegetatiekwaliteit van in Nederland voorkomende habitattypen (inclusief typische plantensoorten van die habitattypen). Om dit te bereiken, zijn drie deelonderzoeken uitgevoerd:

A. Het inventariseren van empirische relaties op basis van beschikbare veldgegevens uit stikstofgradiëntstudies over (de soortenrijkdom van) vegetatietypen die relevant zijn voor in Nederland voorkomende habitattypen.

B. Het afleiden van responscurven voor alle in Nederland voorkomende habitattypen waarvoor een KDW bekend is, op basis van de aanwezigheid van kwalificerende soorten én de bedekking van verdringingssoorten in vegetatieopnamen en de bijbehorende depositiegegevens.

C. Het valideren van de afgeleide responscurven voor de habitattypen uit Deel $B$ met de empirische relaties uit Deel $A$.

In deelonderzoek A worden de resultaten uit de beschikbare, deels buitenlandse, studies zodanig gepresenteerd dat er conclusies uit getrokken kunnen worden voor de in Nederland voorkomende habitattypen. Gezien het beschikbare materiaal kan dat in het algemeen niet op het niveau van afzonderlijke habitattypen, maar wel op het niveau van groepen vergelijkbare habitattypen.

In deelonderzoek B zijn de responscurven per habitattype door experts beoordeeld op plausibiliteit op basis van de vorm van de curve onder en boven de bekende KDW's. Op die manier is beoordeeld in hoeverre het met deze methode mogelijk is om het effect van stikstof te onderscheiden van allerlei andere factoren.

In deelonderzoek $C$ zijn de resultaten van deel $B$ vergeleken met die van deel A, voor zover het habitattypen betreft die voldoende overeenkomen met de (groepen van) habitattypen die in deel $A$ worden behandeld.

Dit onderzoek is gesubsidieerd door het Ministerie van Landbouw, Natuur en Voedselkwaliteit (LNV). In het onderzoek participeerden Wageningen Environmental Research (WEnR) van Wageningen University \& Research (WUR) en onderzoeksbureau B-Ware. Het onderzoek van B-Ware betreft Deel A. Het onderzoek van WENR betreft Deel B. Aan deel C hebben beide partners bijgedragen. Op verzoek van subsidieverstrekker heeft de Taakgroep Ecologische Onderbouwing (TEO) gefungeerd als begeleidingscommissie. De auteurs hebben ook dankbaar gebruikgemaakt van specifieke kennis van afzonderlijke TEO-leden. De inhoud van het rapport komt geheel voor rekening van de auteurs.

Alle data en programmatuur zijn vrij beschikbaar en toegevoegd aan dit rapport, op een belangrijke uitzondering na. De gebruikte vegetatieopnamen uit de EVA-database zijn niet vrij verkrijgbaar. Gebruik van de data is mogelijk nadat een aanvraag voor toestemming is gedaan via http://euroveg.org/eva-database. 


\section{Afbakening}

In dit project is de relatie tussen stikstofdepositie en de kwaliteit van habitattypen onderzocht. De kritische depositiewaarden dienen als vergelijking. Er zijn in dit onderzoek geen nieuwe kritische depositiewaarden afgeleid.

Het onderzoek beperkt zich tot de in Nederland voorkomende habitattypen en zijn strikt genomen ook alleen bruikbaar in Nederland.

Alleen habitattypen met een vastgestelde kritische depositiewaarde zijn onderzocht.

De effecten van stikstofdepositie op bodem- en waterkwaliteit zijn geen onderdeel van deze studie, hoewel de effecten op de vegetatiekwaliteit wel grotendeels via het verzurende en vermestende effect op bodem en water verlopen. Ook de effecten op diersoorten die typisch zijn voor habitattypen zijn geen onderdeel van dit onderzoek.

In dit onderzoek is gewerkt met de gemiddelde depositie per jaar en niet met de geaccumuleerde depositie.

\section{Leeswijzer}

Het rapport bestaat uit drie delen. In deel A wordt beschreven hoe de empirische veldmetingen zijn verzameld en worden de resultaten daarvan besproken en bediscussieerd. In deel B wordt het schatten van de statistisch bepaalde responscurven beschreven en besproken. In dit deel worden ook de verdringingssoorten bediscussieerd. In deel $C$ worden de responscurven uit deel $B$ gevalideerd met de empirische veldmetingen uit Deel $A$. Deel $C$ sluit af met een samenvattende discussie en conclusies. 


\section{A Empirisch bepaalde relaties tussen de hoeveelheid stikstofdepositie en de kwaliteit van habitattypen}

Roland Bobbink ${ }^{1}$

\section{A.1 Inleiding}

Habitattypen worden op Europees niveau beschermd, met name vanwege hun betekenis voor het duurzame behoud van biodiversiteit. Die biodiversiteit is in de habitattypen vertegenwoordigd door de samenstellende plantengemeenschappen (of vegetatietypen) en de typische planten- en diersoorten. Welke dat per habitattype zijn, staat in de zogenoemde profielen (Anonymus, 2014).

Plantengemeenschappen zijn gedefinieerd in Schaminée et al. (1995). Op Europese schaal wordt echter met verschillende vegetatiekundige indelingen gewerkt en de beschikbare studies zijn niet altijd precies toegesneden op de Nederlandse definiëring van een goede kwaliteit van habitattypen. Dat neemt niet weg dat er wel degelijk gebruikgemaakt kan worden van de resultaten van buitenlandse studies, omdat die een voldoende duidelijk beeld geven van de effecten van stikstof op de kwaliteit van de vegetatie.

In dit onderdeel is het verband tussen dosis en effect geanalyseerd voor verschillende (groepen van) vegetatietypen aan de hand van de uitkomsten van zogenoemde 'gradiëntstudies'. In Europa is in de laatste 10-15 jaar een toenemend aantal van deze gradiëntstudies beschikbaar gekomen, waarin een verband wordt gelegd tussen de atmosferische stikstofdepositie en bepaalde kenmerken (bijvoorbeeld soortenrijkdom) van een vegetatietype. Voor het gebruik van gradiëntstudies in dit rapport is het belangrijk dat er zowel is gemeten in gebieden met een depositieniveau dat onder de kritische depositiewaarde ligt als in gebieden met hogere depositieniveaus, oftewel de hele stikstofgradiënt die voor Nederland relevant is, waarbij het uiteraard essentieel is dat er een betrouwbare waarde is verkregen voor de betreffende stikstofdepositie ter plekke.

Voor het in beeld brengen van de effecten van stikstofdepositie op habitatkwaliteit, is het belangrijk dat in een gradiëntstudie in ieder geval de soortenrijkdom is gemeten in de vorm van het aantal plantensoorten per proefvlak. In de algemene inleiding in dit rapport is aangegeven dat binnen een habitat bepaalde soorten juist kunnen profiteren van stikstof en daarmee zelfs de meer kwetsbare soorten kunnen verdringen. Ook kunnen zich soorten gaan vestigen die niet karakteristiek zijn voor het habitattype, waardoor als gevolg van stikstofdepositie een vegetatie met een goede kwaliteit over gaat in een vegetatie met een matige kwaliteit en uiteindelijk in een vegetatie die niet meer voor het habitattype kwalificeert. Door alleen het totale aantal soorten te meten, wordt het effect van stikstofdepositie op de soorten die feitelijk de kwaliteit bepalen, gemaskeerd. In een deel van de gradiëntstudies wordt dit probleem min of meer ondervangen door (ook) het effect op de karakteristieke (diagnostische) soorten van het habitat te bepalen of op soorten die gebonden zijn aan de nutriëntenarme situaties die kenmerkend zijn voor het betreffende habitat.

Voor dit rapport is alleen gebruikgemaakt van gradiëntstudies waarin vegetaties zijn onderzocht die voldoende vergelijkbaar zijn met die van Nederlandse habitattypen en die in een min of meer vergelijkbare klimaatzone liggen. Dat laatste betekent dat met name die studies relevant zijn die zijn uitgevoerd in Europese landen binnen de Atlantische klimaatzone of op de overgang naar de continentale of boreale klimaatzone, waarbij de vereiste gradiënt in stikstofdepositie met een grote bandbreedte aanwezig is.

\footnotetext{
1 Alle foto's in dit deel van het rapport zijn van de hand van de auteur. Alleen Figuur 1 en Figuur 19 zijn respectievelijk van Friso van der Zee en Edu Dorland.
} 


\section{A.2 Methodiek}

In eerste instantie is door gericht zoeken binnen de bestaande literatuur een overzicht samengesteld van gepubliceerde gradiëntstudies met gegevens uit het in de vorige paragraaf genoemde deel van Europa, waarin het verband tussen soortenrijkdom en soortensamenstelling van de vegetatie en de aanwezige stikstofdepositie is gekwantificeerd. Vervolgens zijn alle eerste auteurs van de betreffende publicaties benaderd met het verzoek om hun gepubliceerde gegevens te gebruiken voor dit rapport. Van alle auteurs is toestemming verkregen en hun gepubliceerde basisgegevens zijn daarna toegestuurd in digitale vorm. Bovendien zijn basisgegevens verkregen van twee studies die nog in de fase van publicatie zitten.

De ervaring heeft geleerd dat in bestaande gradiëntstudies de precieze vorm van de responscurve niet met zekerheid is vast te stellen. Via verschillende statistische technieken kunnen verschillende significante curven worden berekend voor het verband tussen soortenrijkdom en stikstofdepositie, zoals lineair, negatief-kwadratisch, S-vormig (sigmoïd) of via splines. Vaak zijn de verschillen tussen de verklaarde varianties van de verschillende curven dermate klein dat meerdere gefitte lijnen als relatie kunnen worden gekozen, met een ongeveer even grote mate van significantie. Oftewel: dát er een significant verband bestaat tussen toenemende stikstofdepositie en afnemende soortenrijkdom is duidelijk, maar hoe de lijnen in detail lopen, is niet met zekerheid te zeggen. Om

schijnnauwkeurigheid in de uitkomsten te vermijden, is in dit project daarom een eenvoudige methode gebruikt om het globale verband tussen stikstofdepositie en soortenrijkdom direct zichtbaar weer te geven. Dit is gebeurd door de waarnemingen samen te vatten in klassen van stikstofdepositie, en wel zodanig dat de klassengrootte $5 \mathrm{~kg} \mathrm{~N}$ (357 mol) per ha per jaar omvat. De $\mathrm{x}$-as in de figuren bestaat dus steeds uit de klassen 5-10, 10-15 kg/ha/j. etc. Vervolgens zijn de gemiddelde waarden per klasse en het tweezijdige 95\%-betrouwbaarheidsinterval berekend en weergegeven in figuren, waarin de assen bestaan uit de verschillende depositieklassen en het bijbehorende soortenaantal. Op deze wijze is het verband, zonder de spreiding van alle punten in beeld te brengen, direct zichtbaar, zonder dat de suggestie wordt gewekt dat één gefitte lijn de beste is.

De gepresenteerde gegevens betreffen niet alleen de totale soortenrijkdom van de vegetatie, maar vaak ook een onderverdeling in vaatplanten, mossen en soms korstmossen of een onderverdeling in soorten die wel en die niet gebonden zijn aan de nutriëntenarme situaties die kenmerkend zijn voor het betreffende habitat. Ook werden soms afzonderlijke resultaten gepresenteerd voor de karakteristieke soorten van het betreffende vegetatietype. Per onderzoek wordt dit nader toegelicht.

De uitkomsten zijn in de volgende paragrafen weergegeven in volgorde van oplopend habitattypenummer. Het gaat daarbij om droge duingraslanden, droge heiden, kalkgraslanden, heischrale graslanden, montane graslanden, hoogvenen en Atlantische eikenbossen. 


\section{A.3 Resultaten}

\section{A.3.1 Droge duingraslanden (Grijze duinen)}

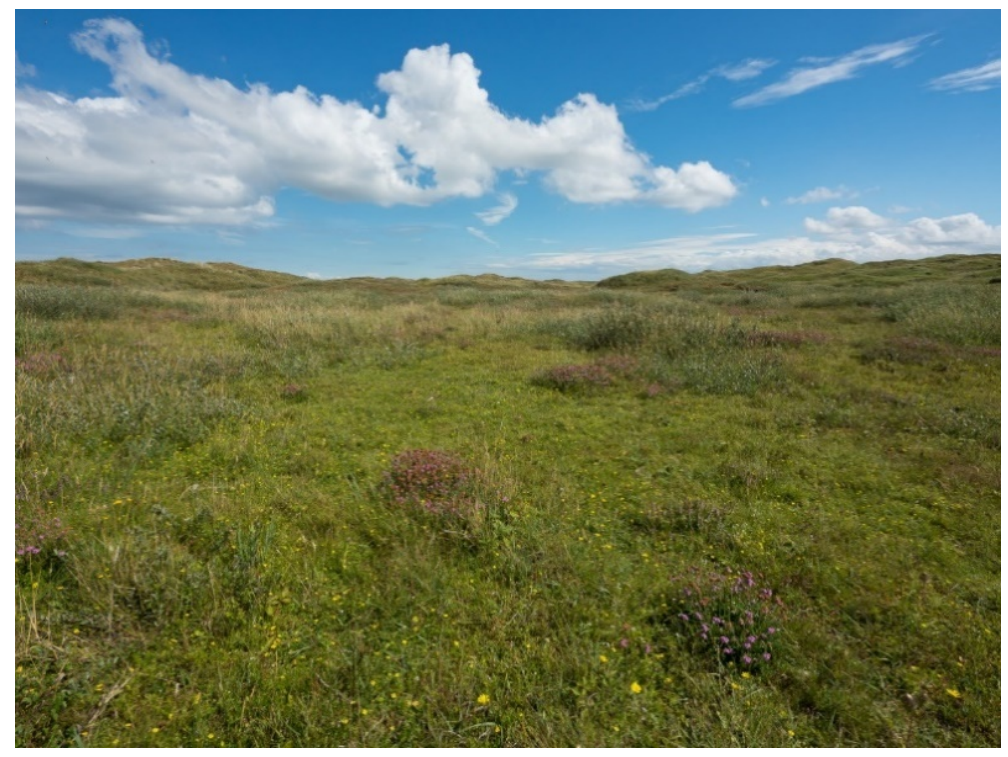

Figuur 1 Droog duingrasland

Droge duingraslanden (EUNIS B1.4 \& habitattype H2130 - Grijze duinen, Figuur 1) zijn veelal zeer soortenrijke graslanden van droge, kalkarme tot kalkrijke kustduinen met een empirische KDW van 8-15 kg N/ha/j.

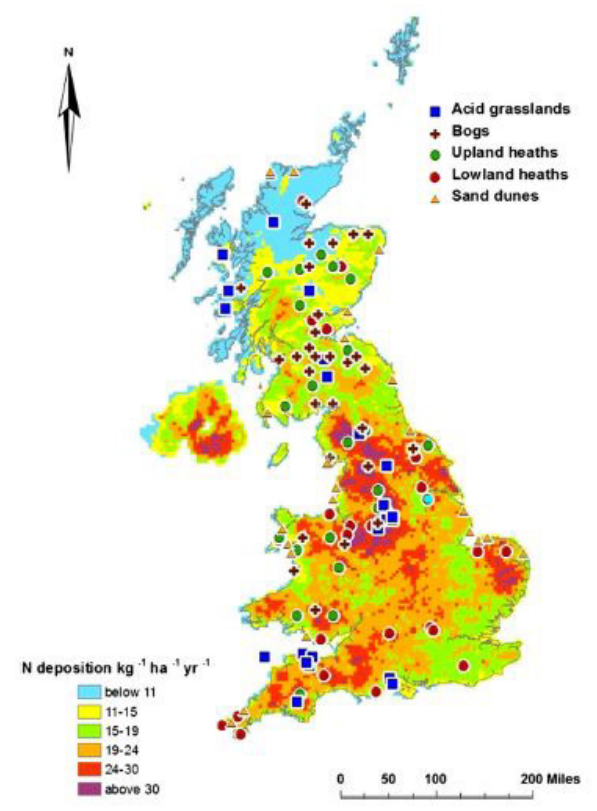

Figuur 2 Overzicht van de bestudeerde locaties verspreid over Groot-Brittannië, met als achtergrond de stikstofdepositiekaart (gemiddelde van 2004-2006; CBED). De driehoekjes zijn de locaties met droge duingraslanden ('sand dunes').

In het Verenigd Koninkrijk is een stikstofgradiëntstudie uitgevoerd in droge duingraslanden (Field et al., 2014) waarvan de data beschikbaar zijn gesteld door dr. Chris Field en dr. Laurence Jones. In 2009 zijn vegetatiebeschrijvingen gemaakt van 24 locaties, verspreid over Engeland, Wales en Schotland. Hierbij zijn de gemiddelde gegevens van de vijf $2 \times 2 m$-proefvlakken per locatie gebruikt, in 
totaal dus 120 proefvlakken. Zowel de bedekking als het voorkomen van alle waargenomen vaatplanten, mossen (exclusief levermossen) en korstmossen is in dit onderzoek vastgelegd. Daarbij is niet vermeld of een soort karakteristiek is voor duingraslanden. De gemiddelde stikstofdepositie (2004-2006) per locatie werd verkregen uit de 5x5km-modellering voor het Verenigd Koninkrijk volgens het Concentration Based Estimated Deposition-model (CBED; Levy et al., 2020) (Figuur 2). De bandbreedte van de gradiënt in stikstofdepositie liep van 5,4 tot $16,8 \mathrm{~kg} \mathrm{~N} / \mathrm{ha} / \mathrm{j}$.

Het totaal aantal plantensoorten in de onderzochte duingraslanden nam in deze studie duidelijk af met toenemende stikstofdepositie, waarbij dit effect sterker zichtbaar is bij mossen (halvering van het aantal soorten per proefvlak) dan bij kruiden. Het effect is vanaf klasse $10-15 \mathrm{~kg} \mathrm{~N} / \mathrm{ha} / \mathrm{j}$. te zien (Figuur 3), zowel voor mossen als voor kruiden, wat overeenkomt met de huidige empirische KDWbandbreedte van 8-15 kg/ha/j. voor dit habitattype (Bobbink \& Hettelingh, 2011). De afname zet zich voort bij hogere depositiewaarden (bij kruiden relatief sterker dan bij mossen).

Helaas was de bandbreedte van de beschikbare gradiënt in $\mathrm{N}$-depositie vrij smal: boven de $16,8 \mathrm{~kg} \mathrm{~N} / \mathrm{ha} / \mathrm{j}$. waren geen locaties beschikbaar, waardoor een eventuele verdere daling in het aantal soorten kruiden of mossen bij hogere stikstofdeposities (in Nederland lopen die in droge duingraslanden nu op tot bijna $23 \mathrm{~kg} / \mathrm{ha} / \mathrm{j}$.) niet kon worden vastgesteld. Het zou de moeite waard zijn om een vervolgonderzoek uit te voeren, waarbij meer locaties met minder dan $5 \mathrm{~kg} \mathrm{~N} / \mathrm{ha} / \mathrm{j}$. depositie, maar vooral ook meer dan $15 \mathrm{~kg} \mathrm{~N} / \mathrm{ha} / \mathrm{j}$. onderzocht worden in een geplande gradiënt.

\section{Soortenaantal (totaal) Duingraslanden}

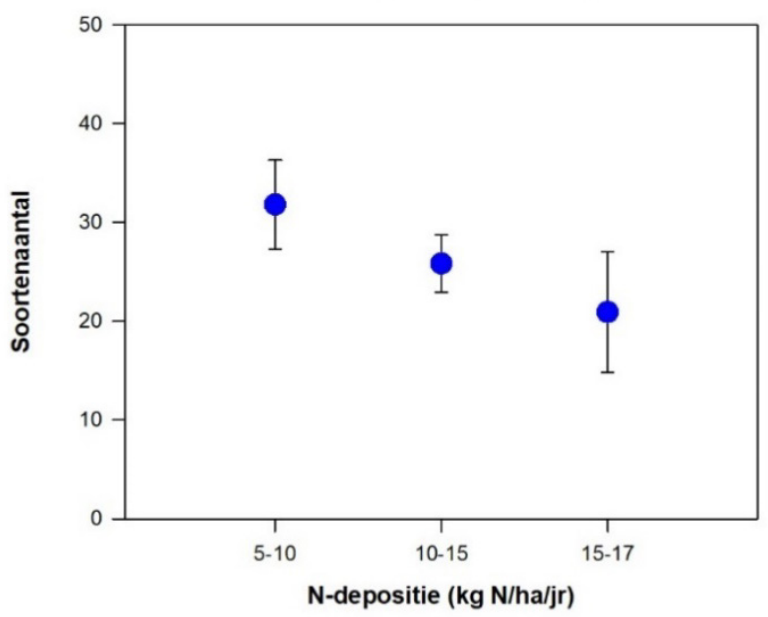

Soortenaantal kruiden (duingraslanden)

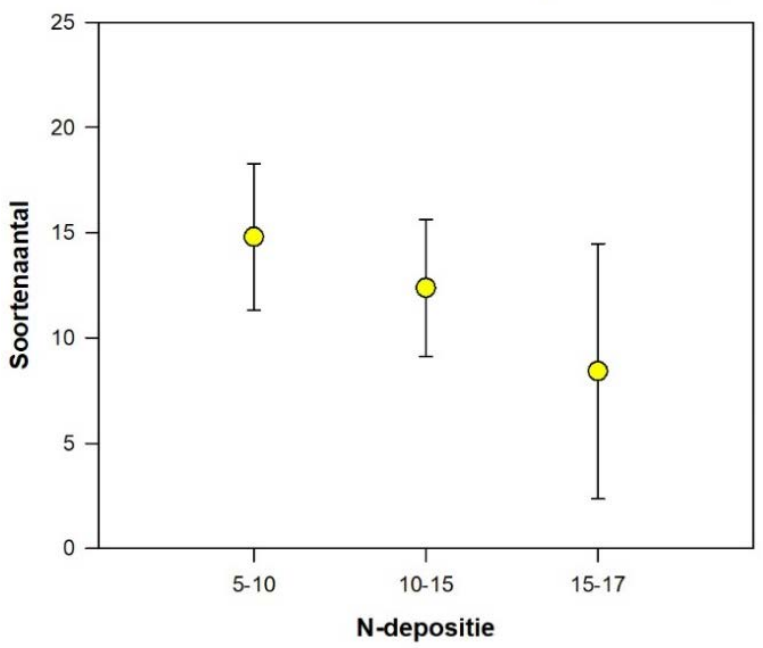

Soortenaantal mossen (duingraslanden)

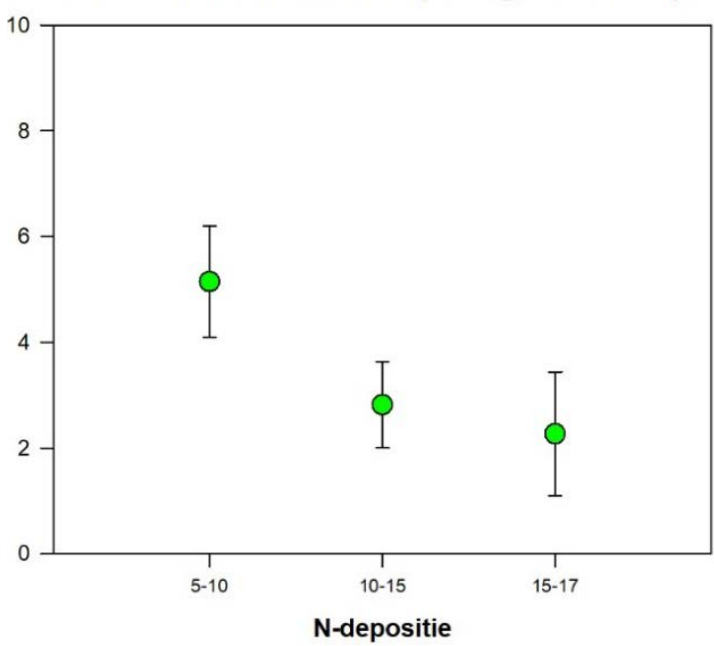

Figuur 3 Totale soortenrijkdom van de vegetatie (blauw) en van het soortenaantal van twee deelverzamelingen, kruiden (geel) en mossen (groen), in droge duingraslanden in het Verenigd Koninkrijk (naar Field et al., 2014). Gemiddelde waarde plus 95\%-betrouwbaarheidsinterval zijn weergegeven. 


\section{A.3.2 Droge heiden}

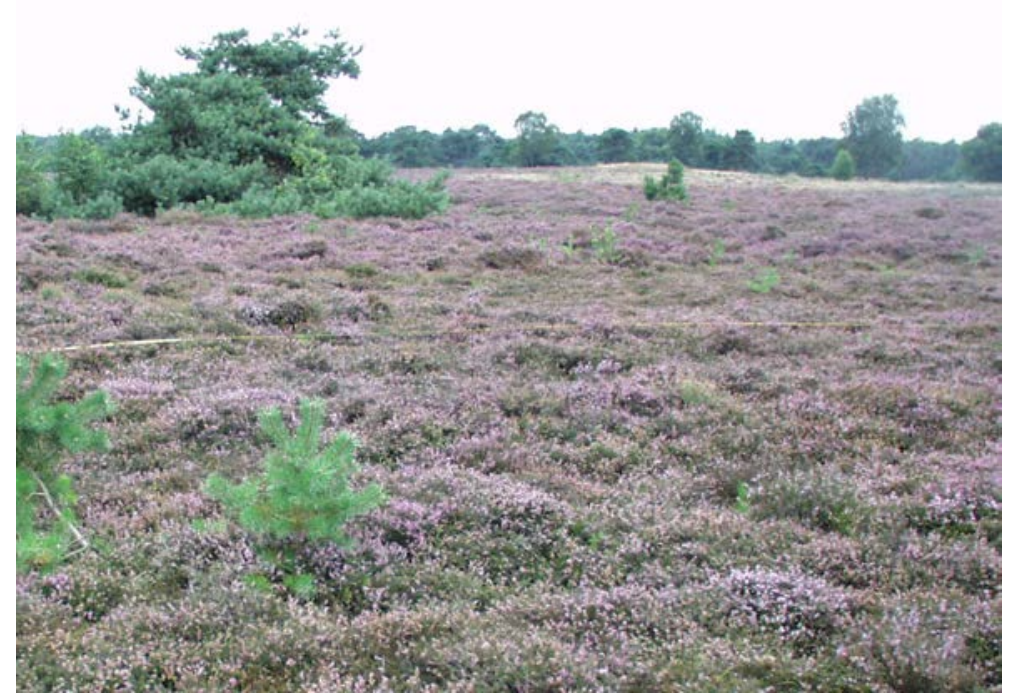

Figur 4 Droge heide met struikhei.

Droge heiden (EUNIS F4.2 \& habitattype H4030 - Droge heiden, Figuur 4) zijn betrekkelijk soortenarme dwergstruikgemeenschappen gedomineerd door struikhei (of blauwe bosbes), met een empirische KDW van $10-20 \mathrm{~kg} \mathrm{~N} / \mathrm{ha} / \mathrm{j}$.

In het Verenigd Koninkrijk is een gradiëntstudie uitgevoerd in door struikhei gedomineerde heiden, zowel in het laagland (EUNIS F4.2; H4030) als in de hooglanden (EUNIS F4.11; H4010 - Vochtige heiden, in een vorm die rijker is aan struikhei dan in Nederland) (Southon et al., 2013; Caporn et al., 2014; Field et al., 2014). De basisgegevens van deze studies zijn beschikbaar gesteld door

prof. dr. Simon Caporn, dr. Chris Field en prof. dr. Sally Power (nu in Australië). Het betrof 27 locaties uit het laagland en 25 locaties uit de hooglanden, verspreid over Engeland, Wales en Schotland (de rondjes in Figuur 2). In 2009 zijn er vegetatiebeschrijvingen gemaakt in vijf 2x2m-proefvlakken per locatie (in totaal 260 proefvlakken), waarna de gemiddelden per locatie zijn gebruikt. Zowel de bedekking als het voorkomen van alle waargenomen vaatplanten, mossen (exclusief levermossen) en korstmossen is in dit onderzoek vastgelegd. Daarbij is niet vermeld of een soort karakteristiek is voor door struikhei gedomineerde heiden. De gemiddelde stikstofdepositie (2004-2006) per locatie werd verkregen uit de $5 \times 5 \mathrm{~km}$-modellering voor het Verenigd Koninkrijk volgens het Concentration Based Estimated Deposition-model (CBED; Levy et al., 2020) (Figuur 5). De bandbreedte van de gradiënt in stikstofdepositie liep van 5,7 tot $32,4 \mathrm{~kg} \mathrm{~N} / \mathrm{ha} / \mathrm{j}$.

In Figuur 5 zijn de resultaten voor alle 52 locaties samengenomen, hoewel in de oorspronkelijke publicatie (Southon et al., 2013) de laagland- en de hooglandlocaties gescheiden zijn geanalyseerd. De samenvoeging is verantwoord vanwege het feit dat de regressielijnen van beide vrijwel gelijklopen. Uit de resultaten blijkt dat het totaalaantal soorten vanaf de klasse $10-15 \mathrm{~kg} \mathrm{~N} / \mathrm{ha} / \mathrm{j}$. slechts weinig daalt. Of er daadwerkelijk sprake is van een sterke daling ten opzichte van de klasse $5-10 \mathrm{~kg} \mathrm{~N} / \mathrm{ha} / \mathrm{j}$. is niet zeker. Weliswaar duiden de gemiddelden daarop, maar door het geringe aantal waarnemingen in de laagste klasse, waarvan één uitbijter met een klein aantal soorten, is niet aan te tonen dat het verband statistisch significant is (zie echter het Intermezzo in paragraaf A.3.3). In Figuur 5 zijn ook deelverzamelingen van soorten weergegeven. Het blijkt dat bij stikstofdeposities boven de $25 \mathrm{~kg} \mathrm{~N} / \mathrm{ha} / \mathrm{j}$. (vrijwel) geen korstmossoorten meer aanwezig waren.

Deze resultaten passen bij het fenomeen dat hierboven al werd benoemd: binnen een habitat kunnen bepaalde soorten juist profiteren van stikstof en daarmee de meer kwetsbare soorten verdringen. Ook kunnen zich soorten gaan vestigen die niet karakteristiek zijn voor het habitattype. Door alleen het totaalaantal soorten te meten, wordt het effect van stikstofdepositie op de soorten die feitelijk de kwaliteit bepalen, gemaskeerd. Bij nadere beschouwing blijken daar duidelijke aanwijzingen voor te zijn in deze studie. Het bleek namelijk dat het bedekkingspercentage van grasachtigen (vooral van 
Deschampsia flexuosa - bochtige smele) hoger was bij een hogere depositie; deze grassen staan dan ook bekend als verdringingssoorten. Ook bij de mossen waren verschuivingen te zien: de bedekking van de mossen Campylopus introflexus (grijs kronkelsteeltje) en Brachythecium rutabulum (gewoon dikkopmos) was positief gecorreleerd met de stikstofdepositie, terwijl de bedekking van de voor (o.a.) heiden kenmerkende mossen Pleurozium schreberi (bronsmos) en Hylocomium splendens (glanzend etagemos) juist negatief gecorreleerd was met de stikstofdepositie. Verder was in de laaglandheide ( $\mathrm{H} 4030$ ) het percentage $\mathrm{N}$ in het strooisel en in de bovengrondse delen van struikhei positief gecorreleerd met stikstofdepositie, terwijl de $\mathrm{C} / \mathrm{N}$-verhouding van de bodem er juist negatief mee gecorreleerd was (Southon et al., 2013; Caporn et al., 2014; Field et al., 2014). Daaruit blijkt dat stikstof zich ophoopt in de bodem en in de heideplanten.
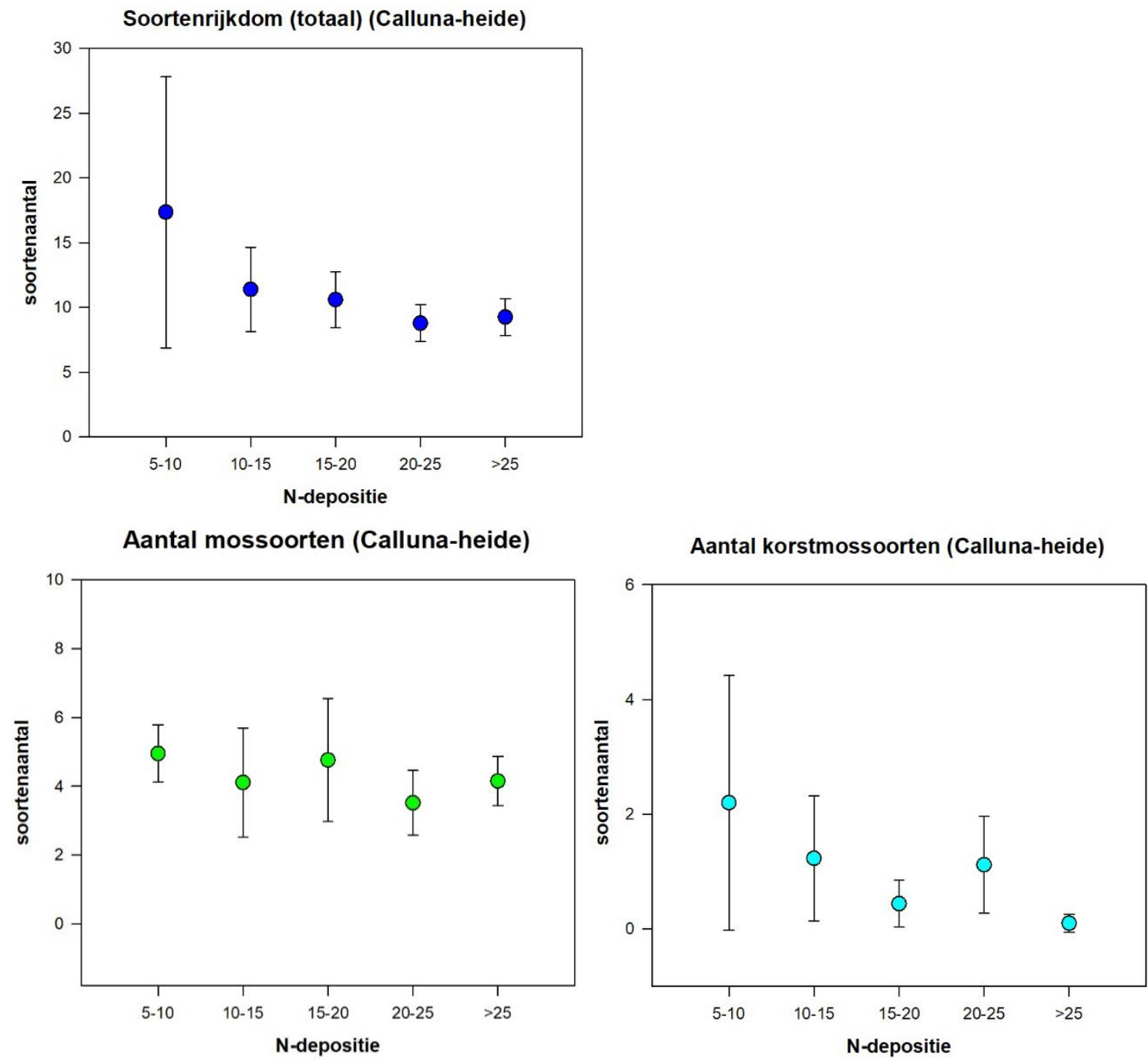

Figuur 5 Totale soortenrijkdom van de vegetatie (blauw) en het aantal soorten mossen (groen) en korstmossen (turkoois) in door struikhei gedomineerde heiden in het Verenigd Koninkrijk (naar Field et al., 2014). Gemiddelde waarde plus 95\%-betrouwbaarheidsinterval zijn weergegeven. 


\section{A.3.3 Intermezzo: het belang van waarnemingen bij zeer lage stikstofdepositie}

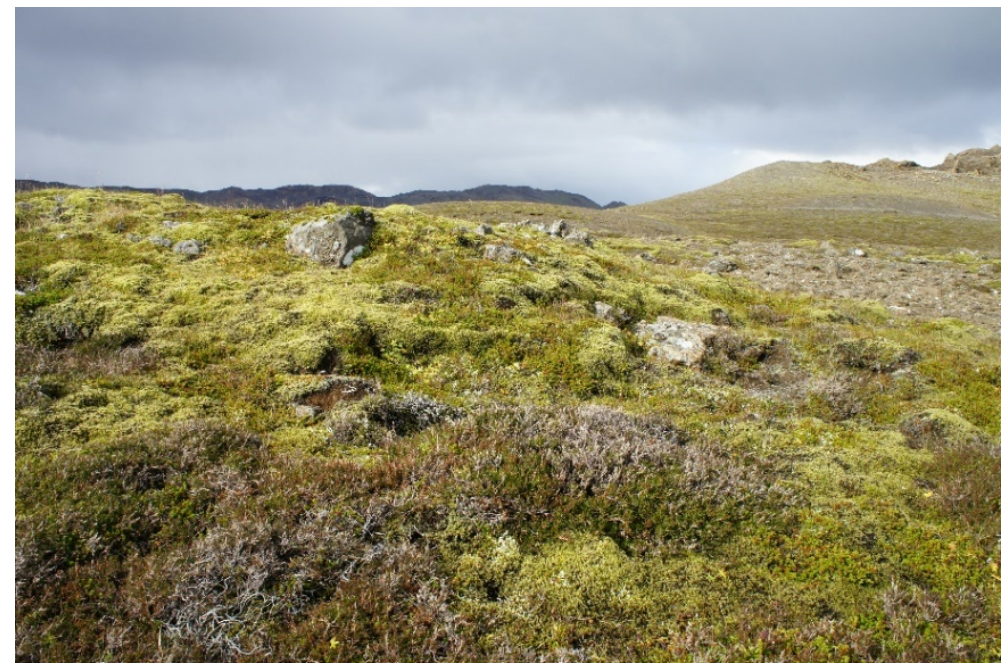

Figuur 6 Alpiene en boreale Racomitrium-heide.

Hoewel het onderzochte vegetatietype niet in Nederland voorkomt, wordt in deze paragraaf toch aandacht besteed aan zogenoemde 'Racomitrium-heide' (EUNIS E4.2; Alpiene en boreale heide (H4060) \& Boreo-Alpien silicool grasland (H6150), Figuur 6). Dit is gedaan om het belang van waarnemingen in gebieden met zeer lage stikstofdepositie aan te tonen. Deze vegetaties worden gedomineerd door mossen (vooral Racomitrium lanuginosum - wollige bisschopsmuts) en korstmossen, al dan niet in combinatie met struikhei of blauwe bosbes. Ze komen voor op bergtoppen in het Verenigd Koninkrijk, maar ook in lagergelegen delen van o.a. Noorwegen en IJsland. In dit vegetatietype werd in 2006 en 2007 een stikstofgradiënt onderzocht (Armitage et al., 2014). Een deel van de basisdata is verkregen via de voor iedereen beschikbare digitale bijlage bij het gepubliceerde artikel. Het onderzoek werd gedaan in het Verenigd Koninkrijk (Wales, Noord-Engeland en Schotland), de Faröer-eilanden en IJsland. Per locatie werd de vegetatiesamenstelling beschreven voor vaatplanten, mossen en korstmossen in 8 tot 16 proefvlakken van $1 \times 1 \mathrm{~m}$. De gemiddelde stikstofdepositie (2004-2006) voor het VK werd verkregen uit de 5x5km-modellering volgens het Concentration Based Estimated Deposition-model (CBED; Levy et al., 2020), terwijl de overige gegevens voor 2006 zijn verkregen op 50x50km-schaal via de EMEP-website (European Monitoring \& Evaluation Programme; http://www.emep.int/). De bandbreedte van de stikstofdepositie liep van 0,6 tot $39,6 \mathrm{~kg} \mathrm{~N} / \mathrm{ha} / \mathrm{j}$. Anders dan in de studie naar de door struikhei gedomineerde heiden, waren er in deze studie wél voldoende waarnemingen in de laagste depositieklasse om statistisch significante uitspraken te doen bij lage depositieniveaus. Aan de andere kant waren er boven de $25 \mathrm{~kg} \mathrm{~N} / \mathrm{ha} / \mathrm{j}$. slechts drie datapunten beschikbaar en daarom zijn deze samengevoegd met die van 20-25 kg N/ha/j. als klasse $>20 \mathrm{~kg} \mathrm{~N} / \mathrm{ha} / \mathrm{j}$ (Figuur 7).

De soortenrijkdom van de vegetatie vertoonde een duidelijk (niet-lineair) negatief verband met de stikstofdepositie: de soortenrijkdom is bij een natuurlijke achtergronddepositie in de klasse onder de $5 \mathrm{~kg} \mathrm{~N} / \mathrm{ha} / \mathrm{j}$. veel hoger dan bij een verhoogde stikstofdepositie. Vanaf de klasse 5-10 kg N/ha/j. bleef de soortenrijkdom constant op een laag niveau. Deze afname van de soortenrijkdom doet zich voor bij zowel dwergstruiken, kruiden als mossen. Ook de bedekking van de korstmossen was boven de $5 \mathrm{~kg} \mathrm{~N} / \mathrm{ha} / \mathrm{j}$. veel lager dan in de onderzochte vegetatie met een heel lage stikstofdepositie. Dat gold ook voor de naamgevende mossoort Racomitrium lanuginosum. Alleen de bedekking van de grasachtigen was positief gecorreleerd met de stikstofdepositie, dus ook bij dit habitat speelt vergrassing (verdringing door grasachtigen) een duidelijke rol.

De gegevens van dit onderzoek laten zien dat het belangrijk is om in gradiëntstudies ook voldoende waarnemingen te hebben uit gebieden met een zeer lage (niet-verhoogde) stikstofdepositie, want alleen daardoor kon het effect van verhoogde depositie op de totale soortenrijkdom worden aangetoond. 
Soortenrijkdom totaal (Racomitrium heide)

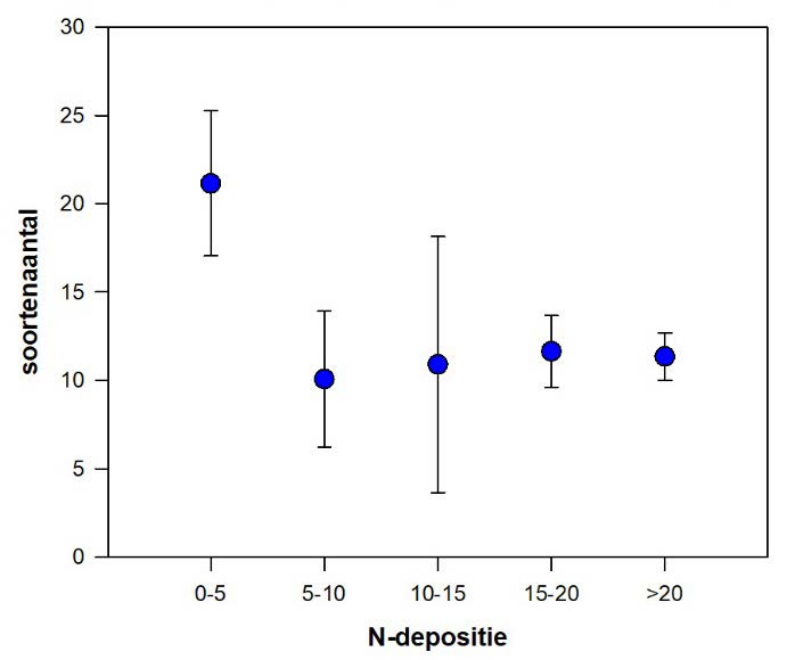

Figuur 7 Totale soortenrijkdom van de vegetatie (vaatplanten, mossen en korstmossen) in Racomitrium-heide in vier landen (naar Armitage et al., 2014). Gemiddelde waarde plus 95\%betrouwbaarheidsinterval is weergegeven.

\section{A.3.4 Kalkgraslanden}

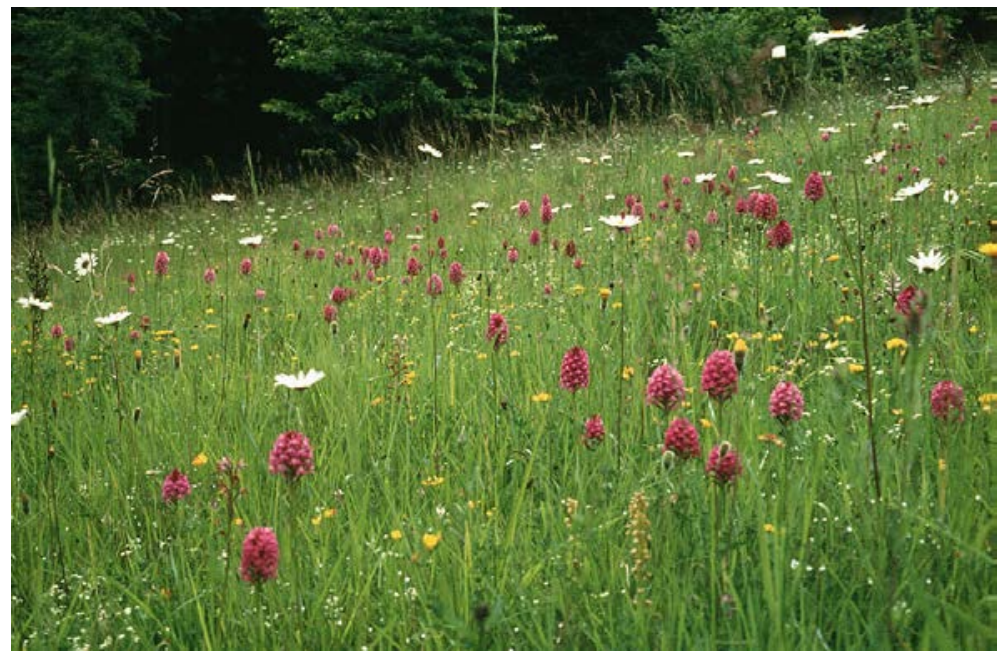

Figuur 8 Kalkgraslanden.

Kalkgraslanden (EUNIS E1.26 \& habitattype H6210 - Kalkgraslanden, Figuur 8) zijn graslanden met een zeer hoge rijkdom aan planten- en diersoorten. Ze komen wijdverbreid in Europa voor op ondiepe, goed gebufferde bodems met kalkgesteente in de ondergrond ( $\mathrm{pH} 7-8$ ). Het zwaartepunt van de matig droge vorm (EUNIS E1.26) ligt in Noordwest-Europa en deze vorm wordt in deze paragraaf behandeld aan de hand van twee gradiëntstudies: één uit het Verenigd Koninkrijk en één uit de hele Atlantische regio. De empirische KDW is 15-25 kg N/ha/j. (Bobbink \& Hettelingh, 2011).

\section{Verenigd Koninkrijk}

In verschillende vormen van kalkgrasland (alle behorend tot de Festuco-Brometalia) is verspreid over Engeland, Schotland en Wales een stikstofgradiënt bestudeerd en gepubliceerd in Van den Berg et al. (2011). De basisdata van deze studie zijn beschikbaar gesteld door dr. Leon van den Berg. Het betrof een onderzoek waarbij de vegetatiegegevens van 121 permanente proefvlakken (grootte van elk proefvlak: $144 \mathrm{~m}^{2}$ ) in natuurgebieden uit de periode 1990-1993 zijn vergeleken met de toen heersende atmosferische stikstofdepositie. De gemiddelde stikstofdepositie per locatie werd verkregen uit de $5 \times 5 \mathrm{~km}$-modellering voor het Verenigd Koninkrijk volgens het Concentration Based Estimated Deposition-model (CBED; Levy et al., 2020). De vegetatiesamenstelling en soortenrijkdom 
(vaatplanten, mossen en korstmossen) werden bepaald via frequentiemetingen in $3650 \times 50 \mathrm{~cm}$ deelproefvlakken verspreid over het proefvlak van $144 \mathrm{~m}^{2}$. De bandbreedte van de gradiënt in stikstofdeposities liep van 7,3 tot 40,7 kg N/ha/j.

Uit de resultaten (Figuur 9) blijkt dat er een groot verschil is tussen het effect van stikstofdepositie op de totale soortenrijkdom en op deelverzamelingen daarvan. Het totaalaantal soorten nam boven de klasse $5-10 \mathrm{~kg} \mathrm{~N} / \mathrm{ha} / \mathrm{j}$ ) af, maar bleef bij toenemende depositie min of meer gelijk. Uit de analyse van de verschillende soortgroepen bleek echter dat het aantal korstmossoorten per proefvlak bij toenemende stikstofdepositie steeds lager werd en dat er boven de $20 \mathrm{~kg} \mathrm{~N} / \mathrm{ha} / \mathrm{j}$, hooguit 1 soort voorkwam en vaak zelfs geen enkele soort (Figuur 9, linksonder). Dit komt overeen met de observatie in Nederlandse kalkgraslanden: alle korstmossoorten die in de jaren vijftig van de vorige eeuw nog voorkwamen, waren in de jaren tachtig verdwenen (During \& Willems, 1986). Ook werd gevonden dat enkele zeer zeldzame, kenmerkende soorten vaatplanten boven de $25 \mathrm{~kg} \mathrm{~N} / \mathrm{ha} / \mathrm{j}$. (bijna) volledig waren verdwenen (Figuur 9, rechtsonder).

Soortenrijkdom (totaal) (kalkgrasland UK)

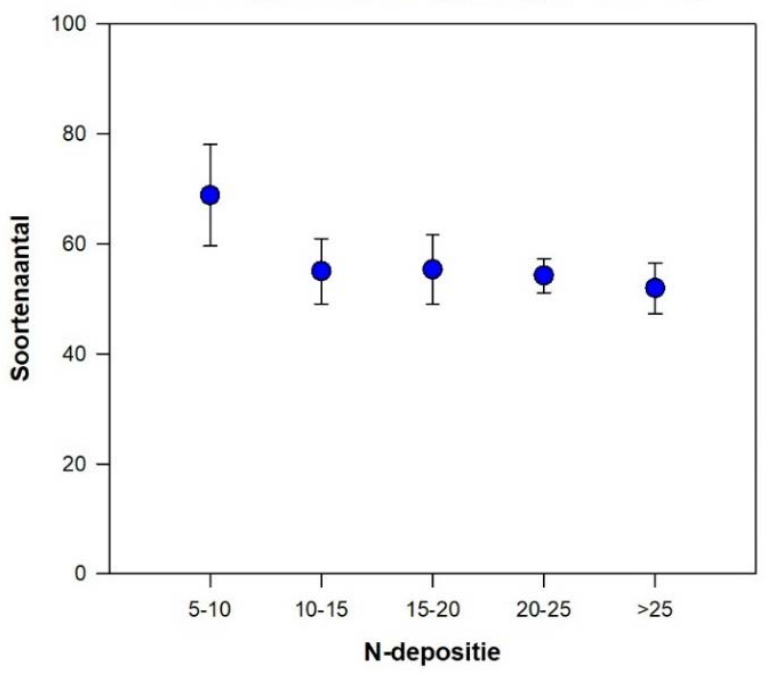

Soortenaantal korstmossen (kalkgrasland UK)

Aantal zeldzame soorten (kalkgrasland UK)
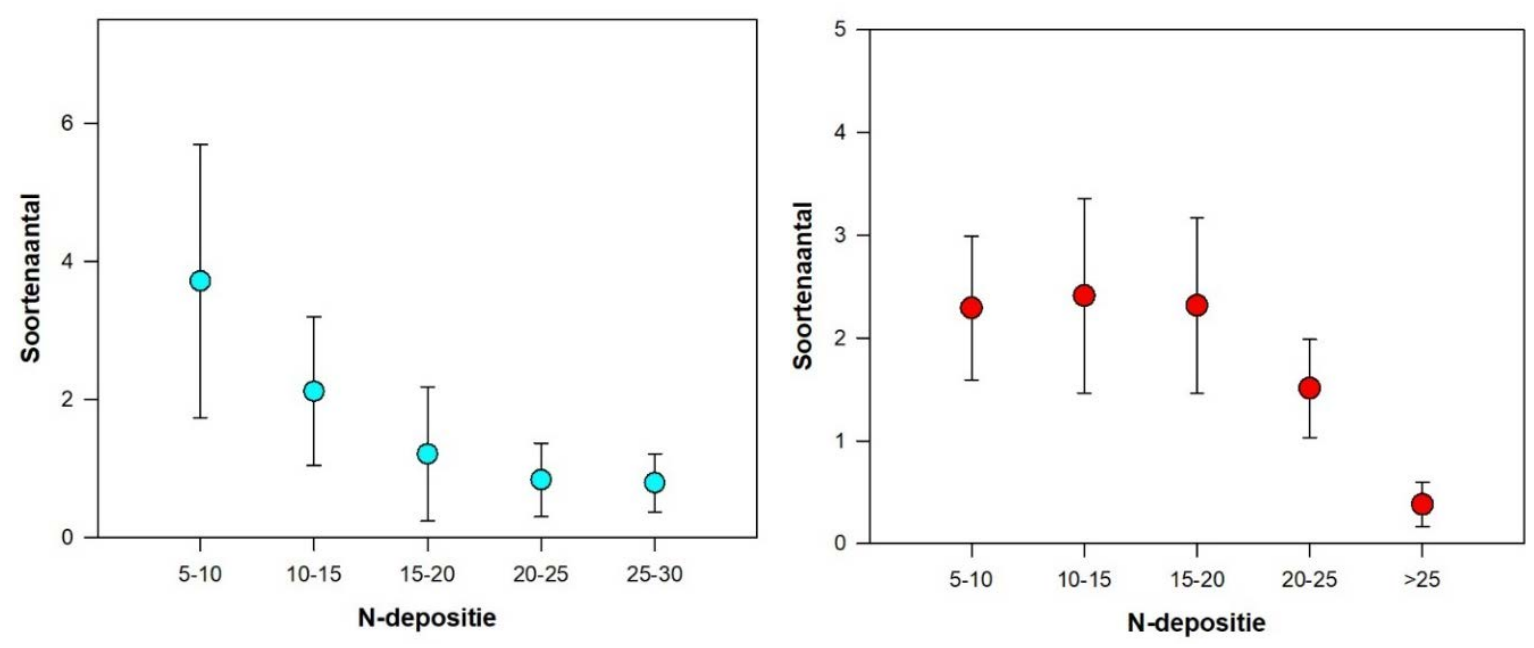

Figuur 9 Totale soortenrijkdom van de vegetatie (blauw), het aantal soorten korstmossen (turkoois) en het aantal zeer zeldzame soorten (rood) in kalkgraslanden in het Verenigd Koninkrijk (Van den Berg et al., 2011). Gemiddelde waarde plus 95\%-betrouwbaarheidsinterval is weergegeven. 


\section{Atlantische regio}

Door het BEGIN-consortium is in 2008 een gradiëntstudie uitgevoerd in matig droge kalkgraslanden (behorend tot het verbond Mesobromion erecti) in de Atlantische regio van Europa. De basisgegevens zijn verstrekt door prof. dr. Didier Allard (Allard et al., in voorbereiding). Per locatie zijn van 5 proefvlakken van $1 \times 1 \mathrm{~m}$ vegetatieopnamen gemaakt (opgenomen met de elfdelige schaal van Domin), waarbij alle soorten vaatplanten en mossen zijn bepaald. Van de korstmossen werd alleen de totale bedekking geschat. De gemiddelde uitkomst per locatie werd gebruikt voor de analyses. Er werden 60 kalkgraslanden onderzocht, verspreid over 5 landen (België, Duitsland, Engeland, Frankrijk en Nederland), gelegen in het centrale deel van de verspreiding van dit type. De gemiddelde stikstofdepositie werd bepaald over 2005-2007 op identieke manier zoals beschreven in Stevens et al., 2010. De bandbreedte van de gradiënt in stikstofdepositie liep van 8 tot $46,5 \mathrm{~kg} \mathrm{~N} / \mathrm{ha} / \mathrm{j}$.

De totale soortenrijkdom van vaatplanten en mossen (per proefvlak) correleerde in deze N-gradiënt, anders dan in de studie uit het Verenigd Koninkrijk, niet met de hoeveelheid stikstofdepositie uit de atmosfeer. Mogelijk ligt zowel het ontbreken van de korstmosdata als ook het gebrek aan locaties met stikstofdepositie onder de $8 \mathrm{~kg} \mathrm{~N} / \mathrm{ha} / \mathrm{j}$. hieraan ten grondslag, want juist hieraan was het effect in het Verenigd Koninkrijk te zien. Echter, in deze dataset is wel degelijk een effect te zien op de voor dit type karakteristieke soorten. Zoals eerder vermeld, kan het effect van stikstofdepositie worden gemaskeerd door het vervangen van karakteristieke soorten door niet-karakteristieke soorten die juist van stikstofdepositie profiteren, waardoor het totaalaantal soorten gelijk blijft. Dat blijkt ook hier het geval, want het aantal soorten per proefvlak dat karakteristiek is voor kalkgraslanden ('Mesobromionsoorten') nam duidelijk af tussen de 10 en 20 kg N/ha/j. (Figuur 10). Daarmee is er dus wel degelijk sprake van een verslechtering van de kwaliteit.

Soortenrijkdom (totaal) kalkgrasland

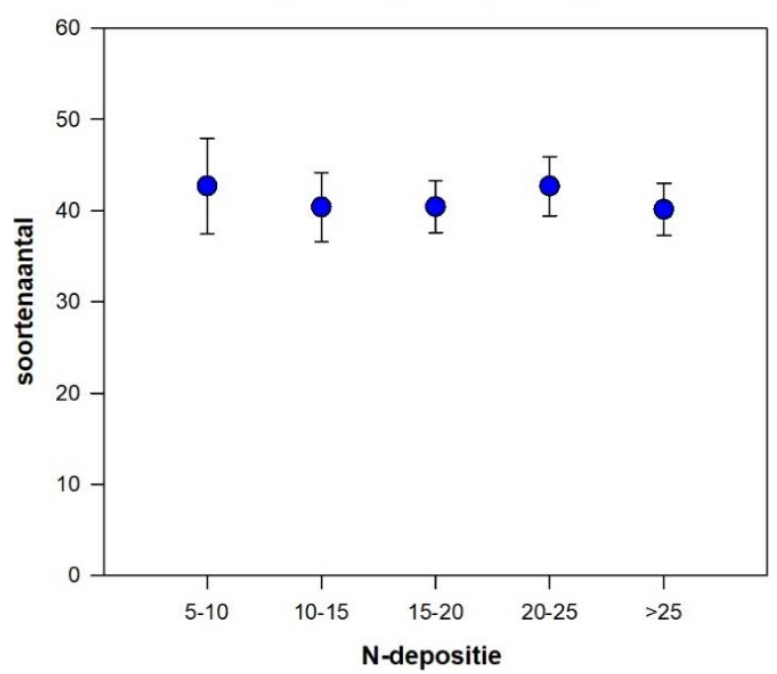

Aantal Mesobromion-soorten

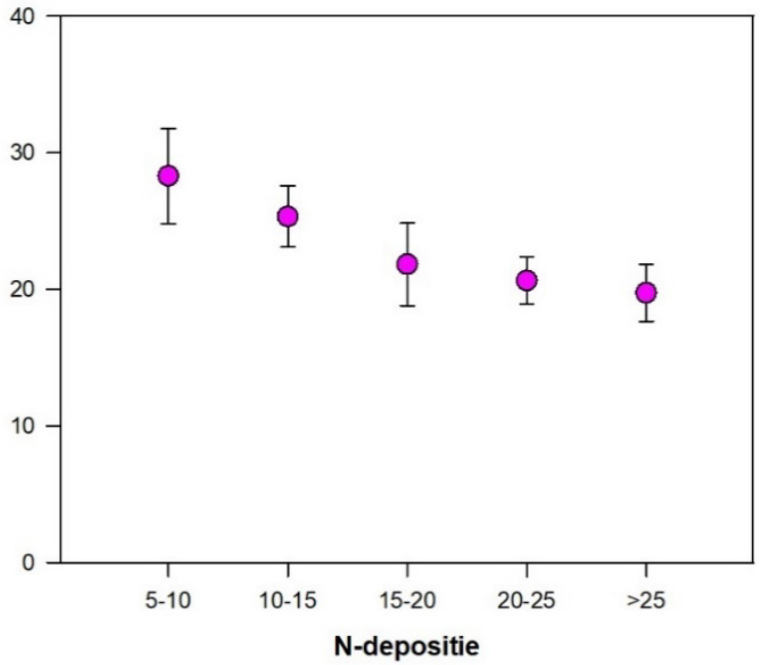

Figuur 10 Soortenrijkdom van de vegetatie (totaal) (blauw) en het aantal kalkgraslandsoorten (Mesobromion) (paars) in kalkgraslanden in vijf West-Europese landen (BEGIN-dataset, Alard et al., in voorbereiding). Gemiddelde waarde plus $95 \%$-betrouwbaarheidsinterval is weergegeven.

De resultaten van beide studies geven aanleiding om te veronderstellen dat de hierboven genoemde bandbreedte van de empirische kritische depositiewaarden van $15-25 \mathrm{~kg} \mathrm{~N} / \mathrm{ha} / \mathrm{j}$. te hoog is, omdat effecten op kenmerkende soorten en op korstmossen al bij lagere waarden optreden. 


\section{A.3.5 Heischrale graslanden}

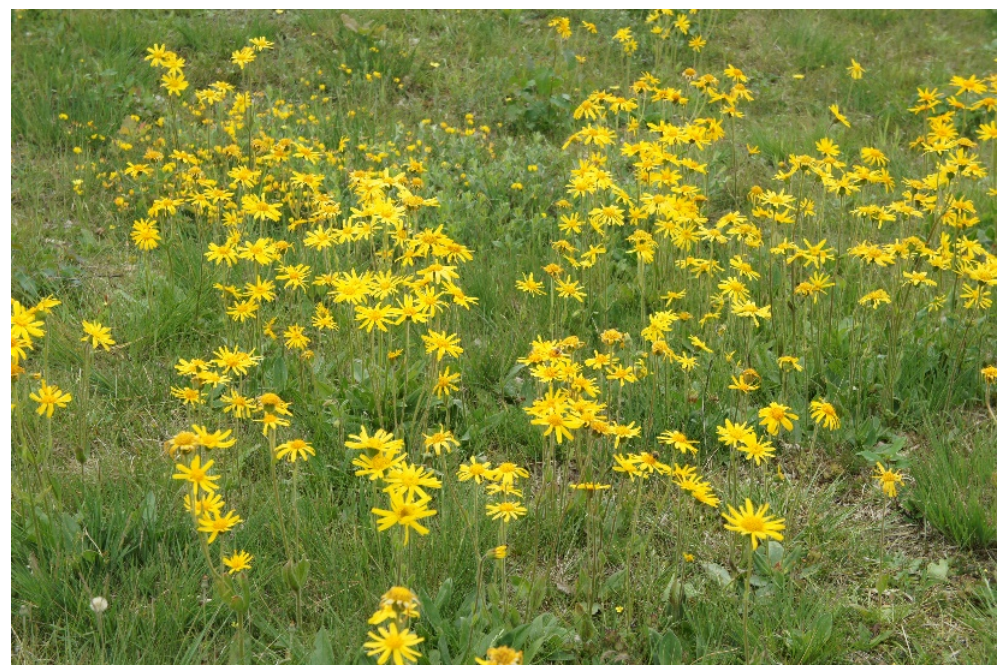

Figuur 11 Heischrale graslanden.

Heischrale graslanden (EUNIS E1.71 en E3.52 \& habitattype H6230 - Heischrale graslanden) zijn graslanden met een (vrij) hoge soortenrijkdom op zwak gebufferde, droge tot matig vochtige bodems. De empirische KDW van droge vormen (E1.71) is $10-15 \mathrm{~kg} \mathrm{~N} / \mathrm{ha} / \mathrm{j}$. en van vochtige vormen (E3.52) 10-20 kg N/ha/j. (Bobbink \& Hettelingh, 2011).

Naast het BEGIN-onderzoek in kalkgraslanden werd door hetzelfde consortium onder leiding van dr. Carly Stevens ook een vergelijkbare gradiëntstudie uitgevoerd in droge en matig vochtige heischrale graslanden in de Atlantische klimaatzone (Stevens et al., 2010, 2011a en 2011b; Dorland et al., 2011). Het betrof 153 locaties in 9 landen, bijna altijd in natuurgebieden (of in ieder geval extensief beheerde gebieden) met een maai- of graasbeheer (het laatste vooral in het Verenigd Koninkrijk). Per terrein werden in 2007 (deels in 2002 in het Verenigd Koninkrijk) vijf vegetatieopnamen gemaakt (van ieder $4 \mathrm{~m}^{2}$; met de schaal van Domin), waarbij alle soorten vaatplanten en mossen zijn bepaald. Van de korstmossen werd alleen de totale bedekking geschat. De gemiddelde uitkomst per locatie werd gebruikt voor de analyses. De stikstofdepositie (het gemiddelde van drie jaren voorafgaande aan de opnamen) werd verkregen met gedetailleerde nationale modellen voor het Verenigd Koninkrijk, Nederland en Duitsland, terwijl dit voor de overige landen gebeurde met het op EMEP gebaseerde IDEM (voor details zie: Stevens et al., 2010). De bandbreedte van de gradiënt in stikstofdepositie liep van 5,1 tot $43,5 \mathrm{~kg} \mathrm{~N} / \mathrm{ha} / \mathrm{j}$. Omwille van de vergelijkbaarheid in de onderhavige studie is één locatie in Noorwegen met $2,4 \mathrm{~kg} \mathrm{~N} / \mathrm{ha} / \mathrm{j}$. nu niet in beschouwing genomen, omdat er geen enkele andere locatie met minder dan $5 \mathrm{~kg} \mathrm{~N} / \mathrm{ha} / \mathrm{j}$. als achtergronddepositie was (de laagste klasse in Figuur 12 is dan ook 5-10).

De totale soortenrijkdom nam significant af met toenemende stikstofdepositie. De sterkste afname lijkt op te treden tussen de klassen 15-20 kg N/ha/j. en 20-25 kg N/ha/j. Deze conclusie hangt wel af van de precieze lijn die wordt getrokken door de punten: een lineaire regressielijn is significant, maar een exponentiële afname is significanter (en is weergegeven in de oorspronkelijke publicatie: Stevens et al., 2010). Dorland \& Van Loon (2011) pleiten echter voor een sigmoïde curve (weergegeven in Figuur 4.2 in hun publicatie): die is even significant, maar ecologisch meer voor de hand liggend. Dit sigmoïde verband (met het steilste gedeelte rond de 20) suggereert ook Figuur 12. Ook werd een aparte analyse uitgevoerd voor het aantal kruiden per proefvlak: hierbij werd gevonden dat de sterkste afname van het aantal soorten kruiden al optrad tussen de klassen $10-15 \mathrm{~kg} \mathrm{~N} / \mathrm{ha} / \mathrm{j}$. en 15-20 kg N/ha/j. Het effect bleek ook groter te zijn dan bij het totale aantal soorten: boven de $25 \mathrm{~kg} \mathrm{~N} / \mathrm{ha} / \mathrm{j}$. is het totale aantal soorten bijna gehalveerd, maar het aantal soorten kruiden is méér dan gehalveerd. Deze resultaten bevestigen de huidige empirische KDW-range voor de droge vorm (10-15 kg N/ha/j.). Verder werd er, zoals verwacht in deze verzuringsgevoelige graslanden, een significante negatieve correlatie tussen stikstofdepositie en de zuurgraad van de toplaag van de bodem gevonden, en een lichte positieve correlatie tussen de stikstofdepositie en het N-gehalte in Rhythidiadelphus squarrosus (gewoon haakmos). 

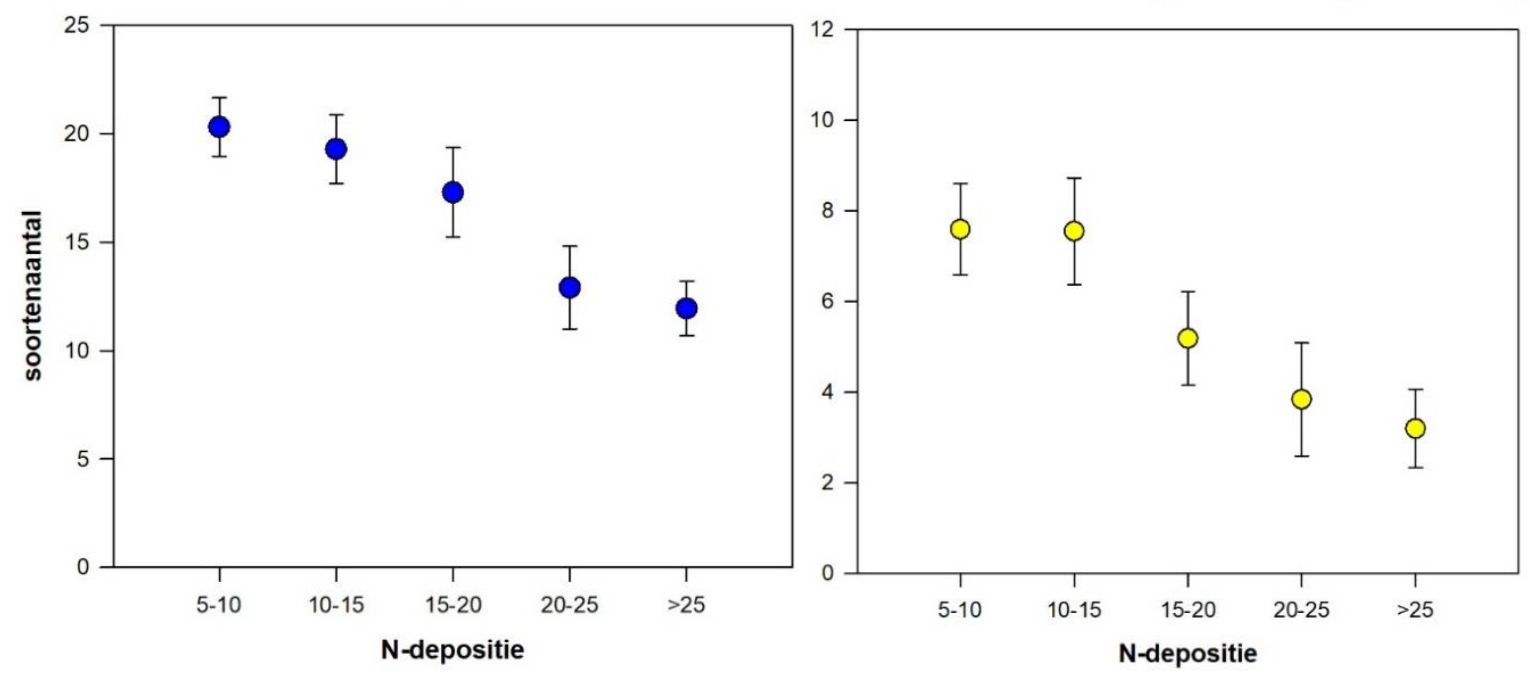

Figuur 12 Totale soortenrijkdom van de vegetatie (blauw) en het aantal soorten kruiden (geel) in heischrale graslanden in West-Europa (BEGIN-dataset, Stevens et al., 2010, 2011a en 2011b). Gemiddelde waarde plus 95\%-betrouwbarheidsinterval zijn weergegeven.

\section{A.3.6 Montane graslanden}

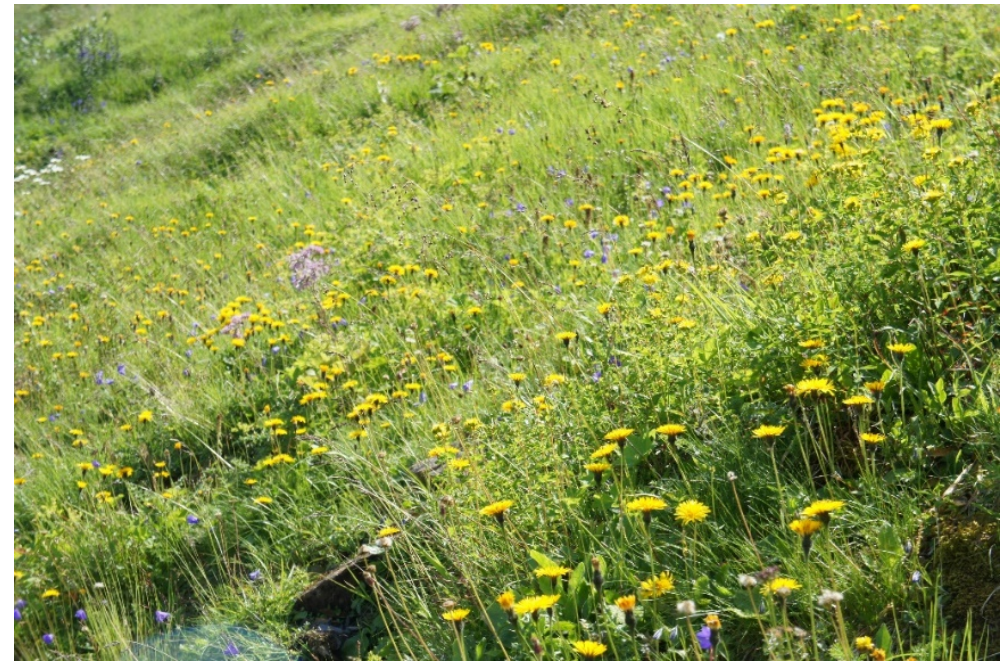

Figuur 13 Montane graslanden.

Montane graslanden (EUNIS E2.3 \& habitattype H6520 - Hooiland in gebergte, Figuur 13) zijn zeer soortenrijke graslanden in de hogere zone van bergstreken, met een empirische KDW van 10-20 kg N/ha/j. Ze komen niet in Nederland voor, maar zijn verwant aan Glanshaver- en vossenstaart-hooilanden (H6510), waarvoor geen gradiëntstudie beschikbaar is.

In deze graslanden is een stikstofgradiënt onderzocht in Zwitserland (Roth et al., 2013; 2017). De basisgegevens werden beschikbaar gesteld door dr. Tobias Roth en dr. Lucas Kohli. Er werden 122 locaties uit het programma 'Biodiversity Monitoring of Switzerland' gebruikt, verspreid over Zwitserland, met cirkelvormige proefvlakken van $10 \mathrm{~m}^{2}$ (Figuur 14). Veel van deze onderzochte graslanden waren in hooilandbeheer, enkele werden alleen begraasd, maar zonder bemesting (bergweiden kunnen bemest worden, maar bemeste montane graslanden zijn niet onderzocht). De vegetatieopnamen werden gemaakt in de periode 2006-2010, waarbij de proefvlakken tweemaal per zomer werden bezocht en waarbij zowel vaatplanten als mossen werden gekwantificeerd. 

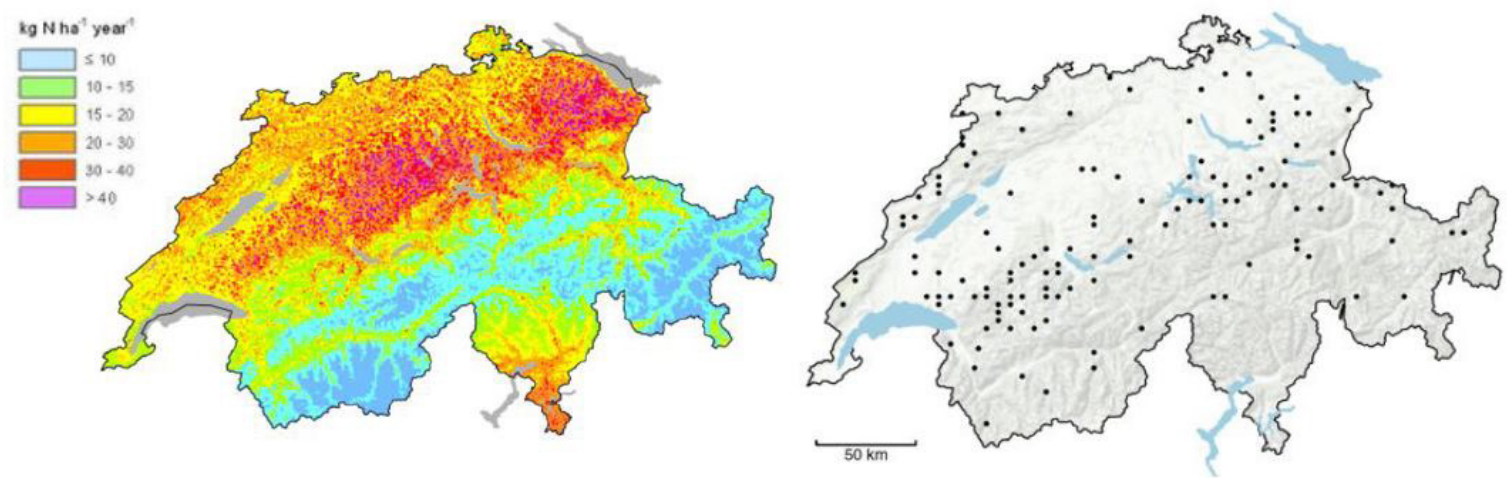

Figuur 14 Stikstofdepositie in Zwitserland (links) en de verdeling van de onderzochte locaties met montane graslanden (rechts) (naar Roth et al., 2013).

De stikstofdepositie werd per locatie bepaald voor het jaar 2007 met het gedetailleerde depositiemodel voor Zwitserland (Rihm \& Kurz, 2001; Kupper et al., 2010), waarbij de range in stikstofdepositie liep van 6,9 tot $31 \mathrm{~kg} \mathrm{~N} / \mathrm{ha} / \mathrm{j}$. Het aantal locaties per klasse van stikstofdepositie was groot, alleen bij 5-10 kg N/ha/j. waren slechts 8 terreinen beschikbaar, waardoor hier het betrouwbaarheidsinterval wat groter is.

Bij de totale soortenrijkdom van de vegetatie lijkt er eerst (onder de empirische KDW) enige toename van het aantal soorten plaats te vinden (hoewel dat strikt genomen geen significante toename is), waarna een daling plaatsvindt boven de klasse 10-15 N/ha/j. (Figuur 15, boven). De verklaring daarvoor kan zijn dat enige toevoeging van stikstof bevorderlijk is voor de vestiging van soorten die afhankelijk zijn van (matig) voedselrijke omstandigheden, terwijl soorten die afhankelijk zijn van voedselarme omstandigheden (nog) niet uit de vegetatie verdwijnen. Deze verklaring wordt ondersteund door de resultaten voor twee deelverzamelingen van soorten, namelijk de soorten die afhankelijk zijn van voedselarme omstandigheden ('oligotrofe soorten') en de soorten die afhankelijk zijn van voedselrijke omstandigheden ('eutrofe soorten'); indifferente soorten zijn hierbij weggelaten (Figuur 15, onder). Daarbij werd duidelijk dat boven de klasse 10-15 kg N/ha/j. het aantal oligotrofe soorten, die zijn aangepast aan de natuurlijke omstandigheden in de bergen en daarom het meest kenmerkend zijn voor montane graslanden, steeds minder werd en boven de $25 \mathrm{~kg} \mathrm{~N} / \mathrm{ha} / \mathrm{j}$. heel laag was (meer dan $85 \%$ lager dan bij deposities onder de $15 \mathrm{~kg} \mathrm{~N} / \mathrm{ha} / \mathrm{j}$.). Het aantal eutrofe soorten, die minder tot niet kenmerkend zijn voor montane graslanden, vertoonde een omgekeerd beeld: laag bij een stikstofdepositie onder de $15 \mathrm{~kg} \mathrm{~N} / \mathrm{ha} / \mathrm{j}$. (circa 10 van de 60 soorten), maar ongeveer dubbel zo hoog bij een $\mathrm{N}$-depositie groter dan $20 \mathrm{~kg} \mathrm{~N}$ ha per jaar. Daardoor veranderde de soortensamenstelling enorm: bij een natuurlijke achtergronddepositie bestaat ruim een derde van de soorten uit kenmerkende, aan voedselarme situaties aangepaste soorten, terwijl boven de $25 \mathrm{~kg} \mathrm{~N} / \mathrm{ha} / \mathrm{j}$. ongeveer de helft van de soorten bestaat uit soorten van voedselrijke omstandigheden (die daarom niet kenmerkend zijn voor montane graslanden) en bijna alle soorten van de eerste groep verdwenen zijn. Deze grote kwaliteitsafname is niet goed af te lezen aan de subtielere veranderingen in totale soortenrijkdom. De uitkomst van de analyse van deze N-gradiënt maakt aannemelijk dat binnen de empirische KDW-range van dit type het daadwerkelijke omslagpunt ongeveer rond de $15 \mathrm{~kg} \mathrm{~N} / \mathrm{ha} / \mathrm{j}$. ligt.

Montane graslanden komen niet in Nederland voor, dus de vraag is wat bovenstaande uitkomsten betekenen voor het meest verwante habitattype, Glanshaver- en vossenstaarthooilanden (H6510). Dat type heeft een empirische KDW van 20-30 N/ha/j., dus aanmerkelijk hoger dan die van montane graslanden. De resultaten voor montane graslanden kunnen dus niet zomaar worden toegepast op H6510. Echter: het fenomeen dat bij de montane graslanden zichtbaar is, blijkt zich in de praktijk ook voor te doen bij H6510, namelijk het verdwijnen van kenmerkende soorten van (in dit geval) matig voedselrijke omstandigheden en de toename van soorten van (zeer) voedselrijke omstandigheden. Zo leidt een te hoge voedselrijkdom bijvoorbeeld tot het vervangen van de Glanshaverassociatie (met kenmerkende soorten) door de Rompgemeenschap van Glanshaver (waaruit de kenmerkende soorten zijn verdwenen). 
Totaal aantal soorten (montane graslanden)

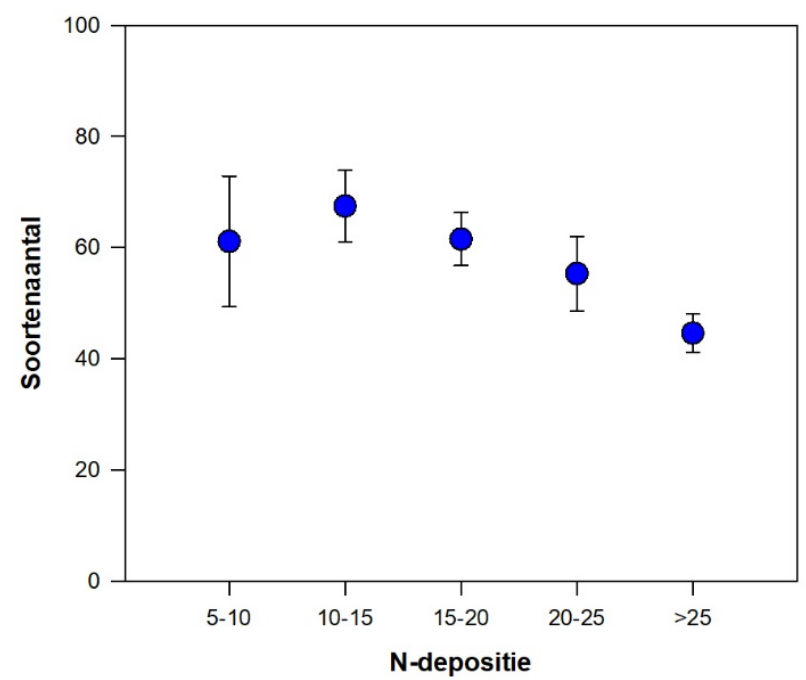

Aantal oligotrofe soorten (montane graslanden)

Aantal eutrofe soorten (montane graslanden)
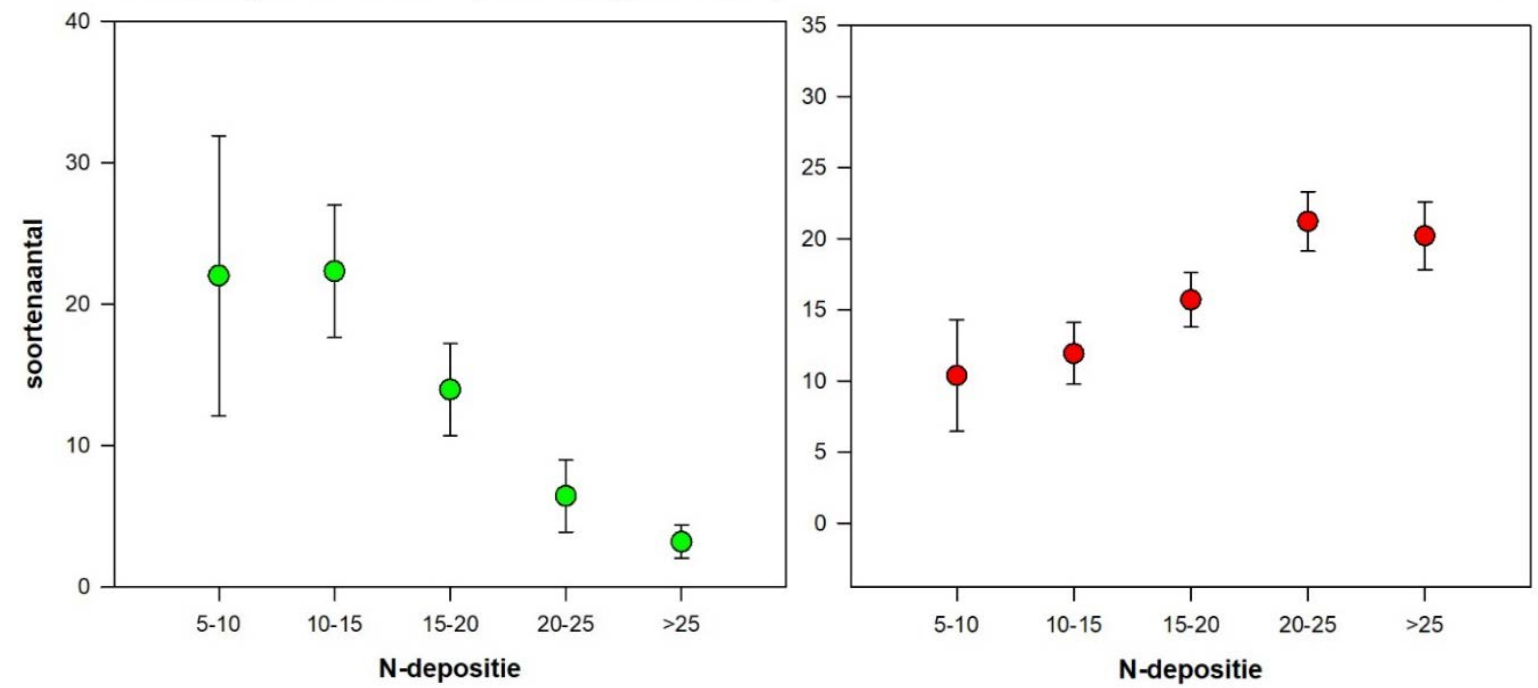

Figuur 15 Totale soortenrijkdom van de vegetatie (blauw), het aantal oligotrofe soorten (Landolt $\mathrm{N}$-getal<3) (groen) en het aantal eutrofe soorten (Landolt N-getal >3) (rood) in montane graslanden in Zwitserland (Roth et al., 2013; 2017). Gemiddelde waarde plus 95\%-betrouwbaarheidsinterval zijn weergegeven. 


\section{A.3.7 Hoogvenen}

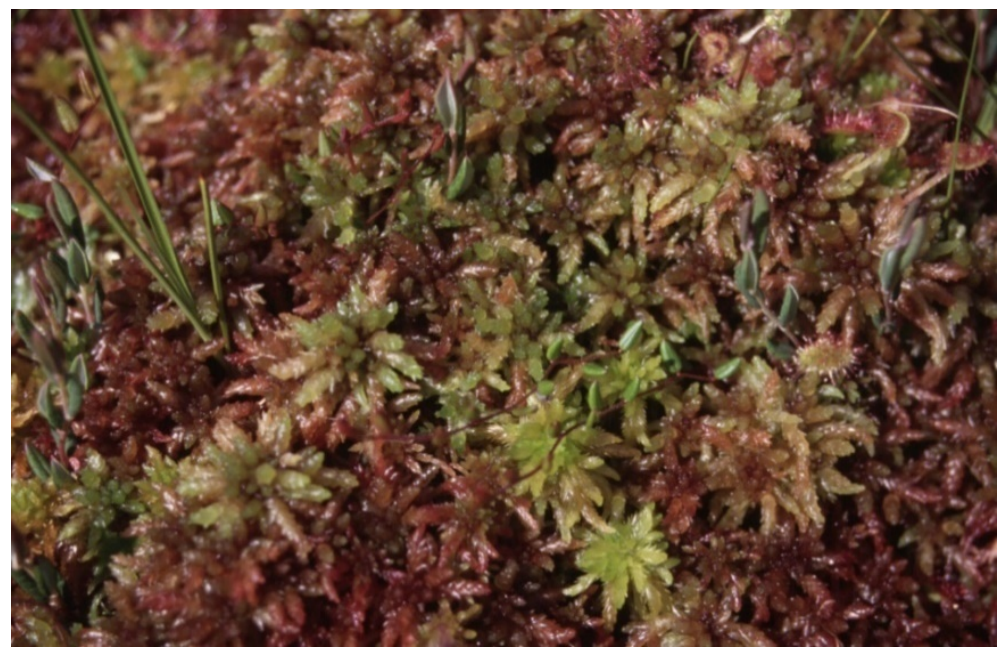

Figuur 16 Hoogvenen worden gedomineerd door veenmossen.

Hoogvenen uit Noordwest-Europa (EUNIS D1 \& habitattype H7110 - Actief hoogveen en H7130 Bedekkingsveen; Figuur 16) zijn relatief soortenarme, door veenmossen gedomineerde landschappen in het laagland (H7110) of op hellingen (H7130), waarbij de toplaag (met de vegetatie) de waterstand reguleert en door afsterving van het plantenmateriaal in de ondergrond veen wordt gevormd. In Nederland komen alleen gewelfde hoogvenen (H7110) voor. De empirische KDW is 5-10 kg N/ha/j. Voor dit type zijn twee gradiëntstudies beschikbaar: één uit het Verenigd Koninkrijk en één uit Noorwegen.

\section{Verenigd Koninkrijk}

De gradiëntstudie in het Verenigd Koninkrijk is vooral in gewelfde hoogvenen uitgevoerd, maar ook in enkele spreihoogvenen (Field et al., 2014). De basisgegevens van deze studie zijn beschikbaar gesteld door dr. Chris Field en dr. Richard Payne. Het betrof 29 locaties verspreid over Engeland, Wales en Schotland (de plusjes in Figuur 2). Er werden in 2009 vegetatiebeschrijvingen gemaakt in vijf 2x2mproefvlakken per locatie, waarvan de gemiddelde gegevens per locatie in de analyse zijn gebruikt. Zowel de bedekking als het voorkomen van vaatplanten, mossen (exclusief levermossen) en korstmossen is onderzocht. De gemiddelde stikstofdepositie (2004-2006) per locatie werd verkregen uit de $5 \times 5 \mathrm{~km}$-modellering voor het Verenigd Koninkrijk volgens het Concentration Based Estimated Deposition-model (CBED; Levy et al., 2020). De bandbreedte van de gradiënt in stikstofdepositie liep van 5,9 tot 30,9 kg N/ha/j. De groep met een stikstofdepositie boven de $25 \mathrm{~kg} \mathrm{~N} / \mathrm{ha} / \mathrm{j}$. omvatte slechts 3 locaties.

In de oorspronkelijke publicatie werd een zwakke, maar net significante negatieve correlatie gevonden tussen de stikstofdepositie en het totaal soortenaantal per proefvlak (Field et al., 2014). Na onderverdeling van de locaties in groepen per klasse van $5 \mathrm{~kg} \mathrm{~N} / \mathrm{ha} / \mathrm{j}$. blijft hier maar weinig van over: er werd geen significant verband aangetoond tussen de soortenrijkdom en verschillende depositieniveaus (Figuur 17), met name omdat de locaties met een depositie in de klasse 10-15 kg N/ha/j. een onverklaarbaar ${ }^{2}$ laag aantal soorten bevatte én omdat de klasse vanaf $25 \mathrm{~kg} \mathrm{~N} / \mathrm{ha} / \mathrm{j}$. slechts 3 locaties omvatte. Wel was de bedekking van grassoorten positief gecorreleerd met de stikstofdepositie. Tevens veranderde de soortensamenstelling met een hogere depositie: er was een toename te zien van Eriophorum vaginatum (eenarig wollegras) en Sphagnum fimbriatum (gewimperd veenmos, een soort van voedselrijkere of verstoorde omstandigheden), maar juist minder Cladonia portentosa (open rendiermos) (Field et al., 2014).

\footnotetext{
2 In de oorspronkelijke publicatie wordt er wel op gewezen dat verdroging een dominantere rol kán spelen bij de afname van soorten dan stikstof. Een verklaring van het lagere aantal soorten in de klasse $10-15 \mathrm{~kg} \mathrm{~N} / \mathrm{ha} / \mathrm{j}$. kan dus zijn dat op de locaties uit die klasse relatief vaak sprake was van verdroging. Het betrekkelijk geringe aantal locaties per klasse maakt de dosis-effectrelatie voor stikstof gevoelig voor dit soort storende factoren ('confounding factors').
} 


\section{Soortenaantal hoogveen UK}

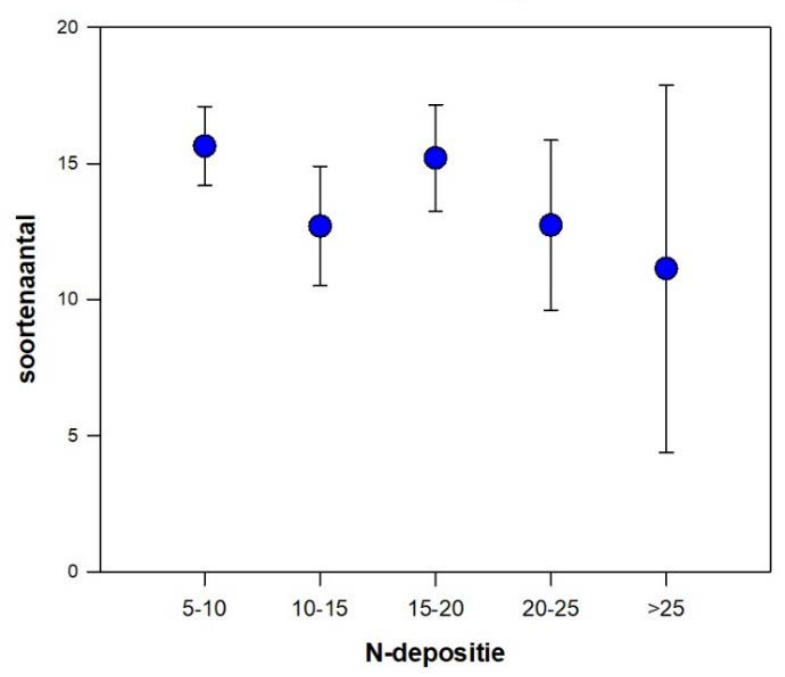

Figuur 17 Totale soortenrijkdom van de vegetatie in hoogvenen in het Verenigd Koninkrijk (naar Field et al., 2014). Gemiddelde waarde plus 95\%-betrouwbaarheidsinterval zijn weergegeven.

\section{Noorwegen}

Ongeveer tegelijk met het onderzoek in het Verenigd Koninkrijk werd ook een stikstofgradiënt onderzocht in Noorwegen (Jokerud, 2012). De basisgegevens van dit onderzoek werden beschikbaar gesteld door dr. Mari Jokerud (Universiteit Bergen/NINA). In het voorjaar van 2021 wordt door haar een manuscript over het onderzoek aangeboden aan een internationaal wetenschappelijk tijdschrift. Het onderzoek werd uitgevoerd in het zuiden en westen van Noorwegen in 2010, waarbij een stratificatie werd toegepast door bij de selectie van locaties slechts één klimaatzone (gematigd oceanisch: gemiddelde zomertemperatuur $10-13{ }^{\circ} \mathrm{C}, 1300-2500 \mathrm{~mm}$ neerslag) te gebruiken, om zo covariatie tussen klimaat en stikstofdepositie te voorkomen. Er werden 20 terreinen met een gewelfd hoogveen geselecteerd, met een soortensamenstelling die sterk overeenkomt met die in goed ontwikkelde delen van Nederlandse hoogvenen. Er werden per locatie 5 vegetatieopnamen (50x50 cm) gemaakt op bulten en 5 op de vlakke delen van het hoogveen (in totaal 100 opnamen). Alle vaatplanten, mossen (inclusief levermossen) en korstmossen werden in het onderzoek betrokken. De stikstofdepositie werd berekend via de Noorse depositiemodellering, waarbij het gemiddelde van 5 jaar voorafgaand aan de monstername werd gebruikt. De bandbreedte van de gradiënt in stikstofdepositie liep van 2,7 tot $17,1 \mathrm{~kg} \mathrm{~N} / \mathrm{ha} / \mathrm{j}$., dus zonder de bandbreedte waarin de Nederlandse hoogvenen zich nu bevinden (vaak 17 tot $30 \mathrm{~kg} \mathrm{~N} / \mathrm{ha} / \mathrm{j}$.). Vanwege het lage aantal locaties met waarden boven de $15 \mathrm{~kg} \mathrm{~N} / \mathrm{ha} / \mathrm{j}$ werden de waarden daarvan samengevoegd met die van 10-15 kg N/ha/j. in de categorie $10-17 \mathrm{~kg} \mathrm{~N} / \mathrm{ha} / \mathrm{j}$.

De resultaten van deze studie laten, door de waarnemingen bij bijna natuurlijke achtergronddepositie, zien wat elders in Europa nauwelijks nog valt vast te stellen. De totale soortenrijkdom van hoogvenen bij een stikstofdepositie boven het (zeer lage) niveau van $5 \mathrm{~kg} \mathrm{~N} / \mathrm{ha} / \mathrm{j}$. is al duidelijk lager dan bij de bijna natuurlijke achtergronddepositie (2,7-5 kg N/ha/j.) (Figuur 18). Bij een nadere analyse van welke soortgroep het meest werd beïnvloed, bleek dat met name het aantal mossoorten sterk afnam door verhoogde stikstofdepositie. Kortom, in deze hoogveenstudie werd, net zoals die in Racomitriumheide, al een afname van de soortenrijkdom zichtbaar bij de klasse 5-10 kg N/ha/j., wat het belang van een gradiënt met zeer lage stikstofdepositie voor een adequaat onderzoek nog eens duidelijk maakt. Verder bevestigt deze studie de empirische KDW van 5-10 kg N/ha/j. 

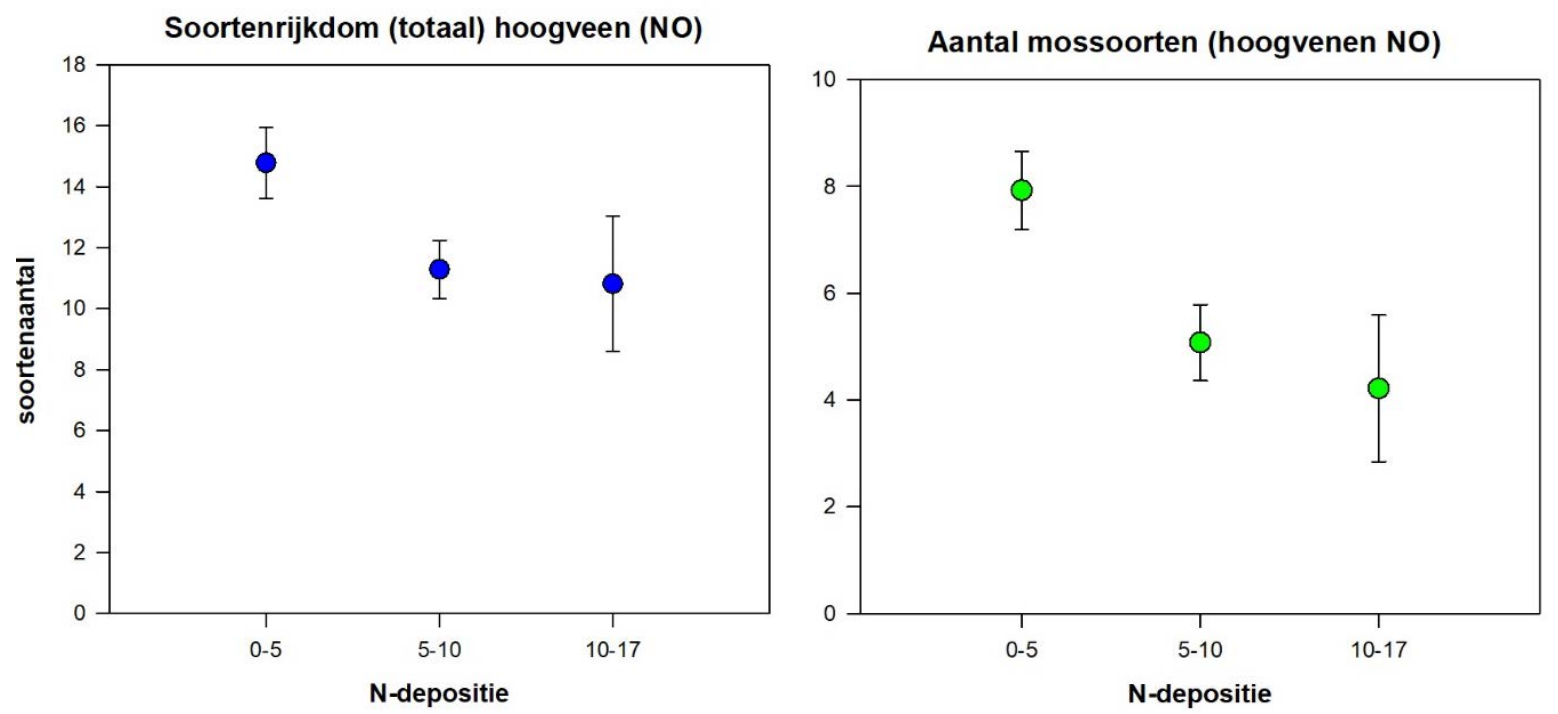

Figuur 18 Totale soortenrijkdom van de vegetatie (blauw) en aantal mossoorten (groen) in hoogvenen in Noorwegen (naar Jokerud, 2012). Gemiddelde waarde plus 95\%betrouwbaarheidsinterval zijn weergegeven.

\section{A.3.8 Atlantische eikenbossen}

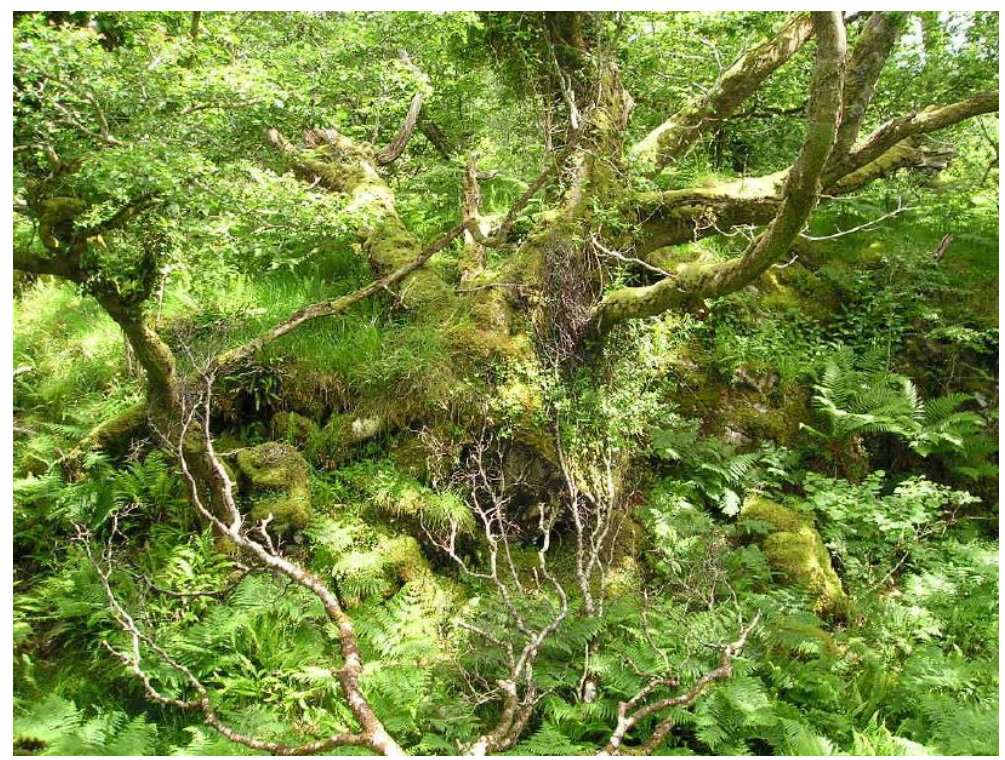

Figuur 19 Atlantische eikenbossen.

Atlantische eikenbossen (EUNIS G1.83 \& habitattype H91A0 - Oude eikenbossen van de Britse eilanden met Ilex- en Blechnum spp.; Figuur 19) zijn door eiken en berken gedomineerde, varen- en (korst)mosrijke bossen die voorkomen op relatief zure bodems in Ierland en het Verenigd Koninkrijk. Ze zijn nauw verwant aan de in Nederland voorkomende Oude eikenbossen (EUNIS G1.81 \& habitattype H9190) en aan een deel van de in Nederland voorkomende Beuken-eikenbossen met hulst (EUNIS G1.82 \& habitattype H9120). De empirische KDW is $10-15 \mathrm{~kg} \mathrm{~N} / \mathrm{ha} / \mathrm{j}$.

De gradiëntstudie in dit type is uitgevoerd in Ierland (Wilkins \& Aherne, 2016). De gegevens van deze studie zijn beschikbaar gesteld door dr. Kayla Wilkins en dr. Julian Aherne. Het betrof 260 vegetatieopnamen $(10 \times 10 \mathrm{~m})$, verspreid over Ierland. Deze vegetatiebeschrijvingen werden op een standaard wijze uitgevoerd onder auspiciën van de Ierse National Park \& Wildlife Service (NPWS) in de periode 2003-2007. Zowel de bedekking als de soortensamenstelling is genoteerd voor vaatplanten en mossen. Helaas is dat niet gebeurd voor korstmossen, hoewel deze bossen bekendstaan om hun korstmosrijkdom en korstmossen extra gevoelig zijn voor stikstofdepositie. De 
stikstofdepositie per locatie werd verkregen van de gedetailleerde $5 \times 5 \mathrm{~km}$-modellering voor stikstofdepositie in Ierland (Henry \& Aherne, 2014). De bandbreedte van de gradiënt in stikstofdepositie liep van 5,4 tot $32,7 \mathrm{~kg} \mathrm{~N} / \mathrm{ha} / \mathrm{j}$. Het aantal opnamen is in vrijwel elke klasse groot en alleen relatief laag $(n=12)$ in de hoogste klasse $(30-33 \mathrm{~kg} \mathrm{~N} / \mathrm{ha} / \mathrm{j}$.).

De totale soortenrijkdom van vaatplanten en mossen van deze eikenbossen werd duidelijk negatief beïnvloed door de hoeveelheid stikstofdepositie: deze waarde is in de klasse $10-15 \mathrm{~kg} \mathrm{~N} / \mathrm{ha} / \mathrm{j}$. al direct $25 \%$ lager dan in de laagste categorie (5-10 kg N/ha/j.), terwijl er daarna nog een geleidelijke daling tot bijna een halvering van het soortenaantal werd gevonden (Figuur 20). De sterke vermindering van het totaal soortenaantal van deze bossen bij al lage stikstofdepositie houdt waarschijnlijk verband met het zeer hoge aantal mossoorten. Voor deze bossen was ook een door de NPWS gehanteerde lijst van in totaal 27 indicatorsoorten beschikbaar, waardoor ook het aantal indicatorsoorten per opname kon worden weergegeven. Het gevonden verband met de stikstofdepositie is duidelijk negatief, hoewel met een minder groot verschil tussen de klassen 5-10 en 10-15 kg N/ha/j. Dat wordt mogelijk verklaard door het feit dat de lijst van (meestal algemene) soorten opgesteld is op basis van opnamen uit de jaren 2003-2007, waarbij al veel opnamelocaties te lijden hadden van overbelasting met stikstof, zodat deze 'positieve indicatoren' in feite niet behoren tot de gevoeligste voor stikstofdepositie.

De auteurs van het artikel komen middels een Threshold Indicator Taxa ANalysis (TITAN) tot de conclusie dat er een omslagpunt in de soortensamenstelling is bij 13,2 kg N/ha/j., wat midden in de bandbreedte van de empirische KDW valt. Maar sommige soorten, zoals Carex sylvatica (boszegge) en Luzula multiflora (veelbloemige veldbies), werden al niet meer gevonden vanaf $10 \mathrm{~kg} \mathrm{~N} / \mathrm{ha} / \mathrm{j}$. Dit maakt aannemelijk dat de KDW voor dit type bossen eerder rond de onderkant van de bandbreedte ligt dan aan de bovenkant.

Dit besproken habitattype komt niet voor in Nederland, maar gezien de genoemde verwantschap zouden de uitkomsten vertaald kunnen worden naar H9120 en H9190.
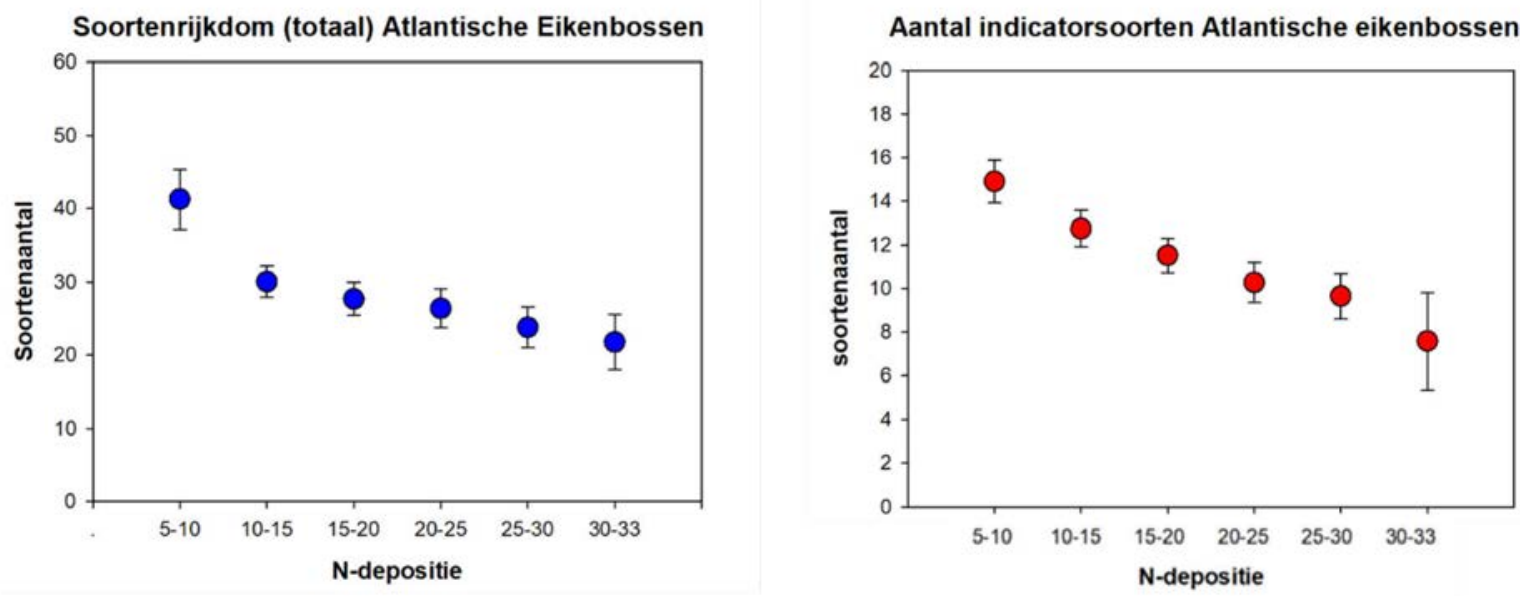

Figuur 20 Totale soortenrijkdom van de vegetatie (blauw) en het aantal indicatorsoorten (rood) in Atlantische eikenbossen in Ierland (naar Wilinks \& Aherne, 2016). Gemiddelde waarde plus 95\%betrouwbaarheidsinterval zijn weergegeven.

\section{A.4 Discussie en conclusies}

In dit onderdeel is via een analyse van gepubliceerde data een overzicht samengesteld van dosiseffectrelaties tussen atmosferische stikstofdepositie en de soortenrijkdom van de vegetatie en zo mogelijk van specifieke plantengroepen. De gegevens zijn gebaseerd op peer-reviewed onderzoek, waarbij de relatie tussen gradiënten in stikstofdepositie en soortenrijkdom is gekwantificeerd en waarbij de gegevens beschikbaar zijn gesteld door de auteurs van de betreffende publicatie (of het ingeleverde manuscript). Hierbij zijn alleen gradiëntstudies gebruikt die (voldoende) relevant zijn voor 
in Nederland voorkomende Natura 2000-habitattypen. Het aantal beschikbare studies was helaas niet groot, maar wel goed verspreid over de EUNIS-hoofdklassen en het Natura 2000-systeem van habitattypen. Er bleken analyses mogelijk voor vijf hoofdgroepen: kustvegetaties, heiden, graslanden, venen en bossen.

Hieronder volgt in het kort een aantal concluderende opmerkingen.

- In alle gradiëntstudies werd een negatieve correlatie gevonden tussen soortenrijkdom en/of -samenstelling van de vegetatie en stikstofdepositie; dit is op een zo gestandaardiseerd mogelijke wijze weergegeven in de figuren voor dit rapport (na analyse van de ontvangen basisgegevens).

- Voor het behoud van biodiversiteit is het belangrijk dat met name de voor habitattypen kenmerkende soorten worden beschermd. In hoeverre stikstofdepositie juist voor deze soorten een bedreiging vormt, is in de gradiëntstudies vaak niet of op een indirecte wijze onderzocht. In alle studies is het effect op de totale soortenrijkdom bepaald. Dat levert meestal, maar niet altijd, een negatief verband op. Vooral bij van nature al relatief soortenarme typen is het verband niet (of minder) duidelijk. Dit resultaat werd eerder gevonden in de metastudie van Soons et al. (2017). Overigens werd in geen van de onderzochte systemen de soortenrijkdom bevorderd door een toenemende $\mathrm{N}$-depositie. Het negatieve effect wordt pas echt duidelijk als naar de meer gevoelige soortgroepen (zoals mossen en korstmossen) wordt gekeken. Het duidelijkst is het effect bij de soorten die juist het afhankelijkst zijn van de omstandigheden die karakteristiek zijn voor het betreffende habitattype. De studie van de montane graslanden toont dat bij uitstek aan. Door alleen te kijken naar de totale soortenrijkdom worden de relevantste effecten van stikstofdepositie dus gemaskeerd, namelijk de vervanging van kenmerkende soorten door algemene soorten die zijn aangepast aan stikstofrijke omstandigheden.

- Het is bekend dat habitattypen op verzuringsgevoelige (zwak gebufferde) bodems een sterkere negatieve reactie laten zien dan habitattypen op gebufferde bodems, omdat de stikstofdepositie bij deze typen niet alleen een eutrofiërend, maar ook een verzurend effect heeft. Dat wordt bevestigd in de hier gepresenteerde studies van twee typen graslanden: de effecten van stikstofdepositie zijn sterker bij de heischrale graslanden (H6230), die voorkomen op zwak gebufferde bodems, dan bij kalkgraslanden (H6210), die door de bufferende werking van de kalkrijke bodem vrijwel niet gevoelig zijn voor bodemverzuring.

- Hoewel de vorm van de responscurve niet voor elk habitattype even eenduidig is, is wel duidelijk geworden dat er grote verschillen bestaan in de dosis-effectrelatie. Waar eerst gedacht werd (naar aanleiding van de resultaten in heischrale graslanden) dat de kwaliteitsverslechtering boven de KDW vrij geleidelijk verloopt, blijkt bij meerdere habitattypen al direct boven de KDW een scherpe terugval plaats te vinden. Bij twee habitattypen (Racomitrium-heiden en hoogvenen) was dat alleen maar aan te tonen doordat ook locaties waren bestudeerd met zeer lage stikstofdepositie (2-5 kg N/ha/j.). Beide studies lieten zien dat al bij een zeer geringe toename van stikstofdepositie (boven de $5 \mathrm{~kg} \mathrm{~N} / \mathrm{ha} / \mathrm{j}$.) een sterke vermindering in soortenrijkdom van de vegetatie kon worden aangetoond. Het betrof met name korstmos- en mossoorten. Dit benadrukt het belang om in gradiëntstudies ook regio's met een (bijna) natuurlijke achtergronddepositie te betrekken.

- Onderzoek naar de relatie tussen gradiënten in stikstofdepositie en biodiversiteit in Natura 2000habitattypen zijn heel nuttig om (lange termijn) verbanden tussen deze factoren aan het licht te brengen. Stratificatie in de meetnetopzet is daarbij relevant, bijvoorbeeld per vegetatietype of habitattype, zoals in de besproken studies ook is gebeurd. Het is voor een optimale analyse essentieel dat de stikstofgradiënt een voldoende bandbreedte heeft met zowel zeer hoge als zeer lage stikstofdepositie. Daarnaast moet in de studie ook rekening worden gehouden met 'confounding factors' die het aanwezige verband tussen stikstofdepositie en habitatkwaliteit verstoren, zoals zwaveldepositie (die net als stikstof tot verzuring leidt) of bijvoorbeeld klimaat. Echter, experimenten met lange termijn-stikstofaddities in gebieden met lage stikstofdepositie blijven essentieel om de causaliteit van de relaties vast te stellen, omdat gradiëntstudies alleen correlatieve verbanden kunnen aantonen. 
De uitkomsten van gradiëntstudies zijn tot op dit moment niet gebruikt om de empirische KDW's van Europa op te stellen (Bobbink \& Hettelingh, 2011), noch bij de interpretatie van de uitkomsten van de gemodelleerde KDW's voor Nederland (zoals gebruikt voor de nadere precisering en aanvulling van empirische KDW's in Van Dobben et al., 2012). Dit betekent dat met de in dit deel gepresenteerde figuren een evaluatie en eventuele aanpassing mogelijk is van de toe nu toe vastgestelde bandbreedte van de empirische KDW's. Een vergelijking tussen de bestaande empirische KDW's en de indicatie voor een waarde die zou kunnen worden afgeleid uit de gepresenteerde figuren, is opgenomen in Tabel 1.

Tabel $1 \quad$ Vergelijking van bestaande KDW's en indicaties op basis van dit deelrapport.

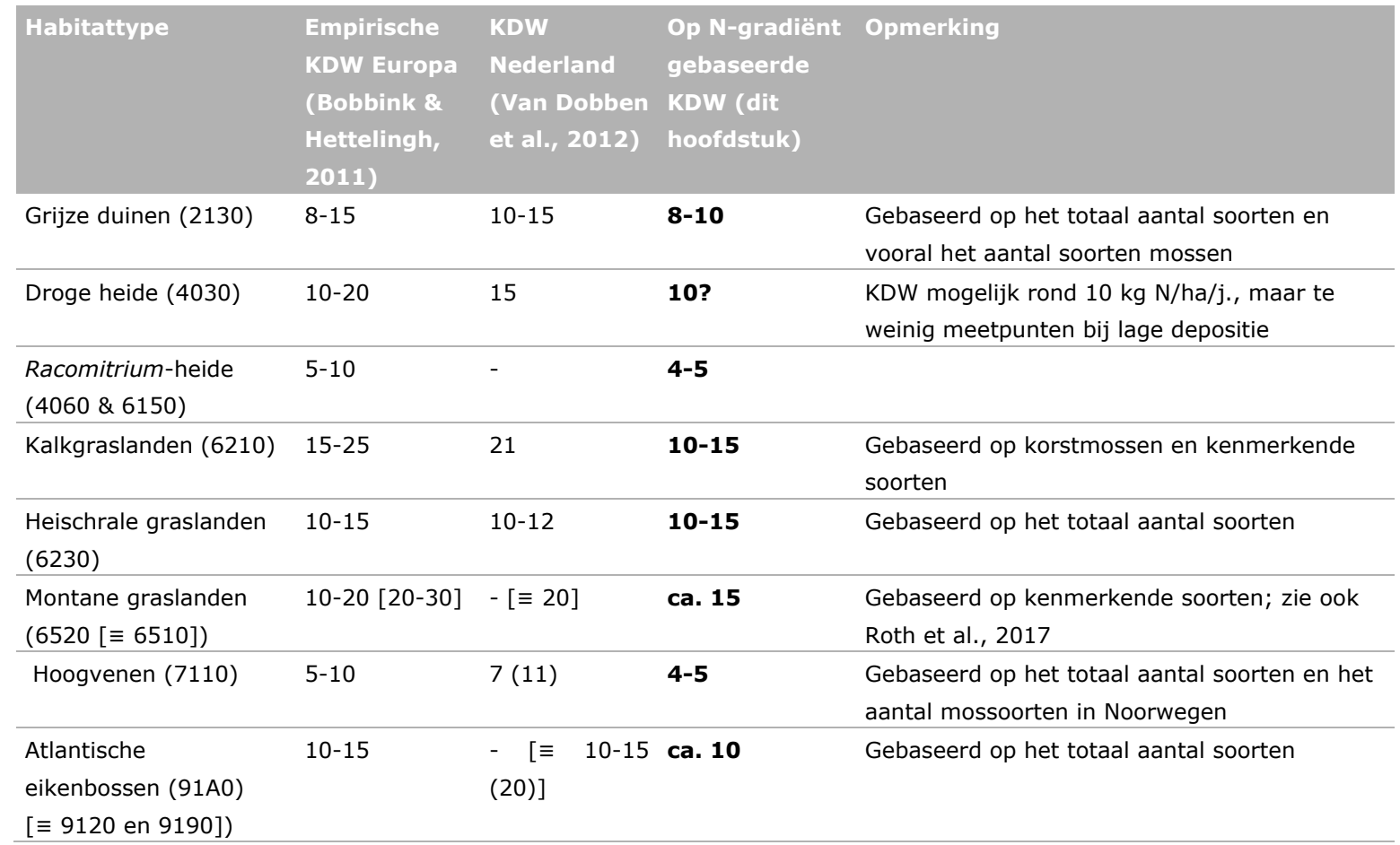

Uit deze vergelijking komt naar voren dat de via de gradiëntmethode ingeschatte (bandbreedte van) KDW's dezelfde ordegrootte hebben als de bestaande (empirische) KDW's. Wel komt meestal de ingeschatte waarde het meest in de buurt van de onderkant van de nu geldende bandbreedte van de empirische KDW. Dit betekent dat de nu geldende KDW's zeker niet aan de hoge kant zijn. Dit rapport had niet tot doel om bestaande KDW's aan te passen. Of de vermelde indicaties zullen worden overgenomen in toekomstige KDW-rapporten, zal moeten blijken. De nu lopende UN/ECE-revisie en -update van de empirische KDW's voor Europa, die eind 2021 gereedkomt, is daarvoor de eerste gelegenheid. 


\title{
B Een verkenning van de statistische relatie tussen de hoeveelheid stikstofdepositie en de kwaliteit van habitattypen
}

\author{
G.W.W. Wamelink, P.W. Goedhart, H.D. Roelofsen, M. Posch \& H.F. van Dobben
}

\section{B.1 Inleiding}

Habitattypen worden op Europees niveau beschermd, met name vanwege hun betekenis voor het duurzame behoud van biodiversiteit. Die biodiversiteit is in de habitattypen vertegenwoordigd door de samenstellende plantengemeenschappen (vegetatietypen) zoals gedefinieerd door Schaminée et al. (1995-1998) en de typische soorten. Welke dat per habitattype zijn, staat in de zogenoemde profielen (Anonymus, 2014). Aan de totale soortensamenstelling op een bepaalde plek is af te lezen om welke plantengemeenschap het gaat. Daarbij wordt gebruikgemaakt van het feit dat soorten in bepaalde vegetatietypen meer voorkomen dan in andere. De mate waarin soorten gebonden zijn aan een vegetatietype wordt 'trouwgraad' genoemd. Het 'meer voorkomen' kan een overwicht in presentie zijn, maar ook een overwicht in bedekking. De soorten waarmee vegetatietypen onderscheiden worden (de diagnostische soorten), zijn dus gebaseerd op hun trouwgraad.

Het doel van dit deel van het onderzoek is om, op basis van vegetatieopnamen, een kwantitatieve relatie te leggen tussen de hoeveelheid stikstofdepositie en de kwaliteit van een habitattype. Deze relatie kan niet rechtstreeks worden gelegd, omdat 1) per vegetatieopname niet is vermeld om welk habitattype het gaat en 2) er geen operationele definitie is van de kwaliteit van een afzonderlijke vegetatieopname. Daarom wordt die relatie op een indirecte manier gelegd, namelijk door gebruik te maken van de in de opnamen aanwezige plantensoorten. Daarbij is het belangrijk dat verschillen in kwaliteit die volgens de profielen van de habitattypen relevant zijn in beeld worden gebracht. Bij typische soorten is dat direct duidelijk: een afname van typische soorten is een afname van habitatkwaliteit. Bij plantengemeenschappen gaat het primair om het behoud van de plantengemeenschappen die volgens het profiel een goede kwaliteit vertegenwoordigen. De soorten die voor die plantengemeenschappen diagnostisch zijn (en dus het verschil aangeven met plantengemeenschappen die niet behoren tot de goede kwaliteit van het habitattype), noemen we in dit rapport 'kwalificerende soorten'. Tot de 'kwalificerende soorten' zijn ook de typische soorten gerekend, omdat die mede de kwaliteit bepalen (de meeste typische soorten zijn tevens diagnostisch voor de samenstellende plantengemeenschappen). Deze set soorten omvat de (planten)biodiversiteit waar het in de bescherming van habitattypen om gaat. ${ }^{3}$

In dit onderzoek is de relatie bepaald op basis van responscurven voor de kans op voorkomen van de bij een habitattype behorende kwalificerende soorten als functie van de stikstofdepositie. Deze responscurven zijn geschat op basis van een Europese database met vegetatieopnamen.

Stikstofdepositie vormt een bedreiging voor een deel van de kwalificerende soorten van stikstofgevoelige habitattypen (zie deel A van dit rapport). In dit deel van het rapport is onderzocht of dat ook zichtbaar te maken is door het schatten van een relatie tussen het voorkomen van kwalificerende soorten en de hoeveelheid stikstofdepositie.

Stikstofdepositie heeft tot gevolg dat, door verzuring en toename van de voedselrijkdom, de abiotische omstandigheden van de groeiplaats van planten veranderen. Dat is voor een deel van de

\footnotetext{
3 De diersoorten zijn voor het doel van dit onderzoek niet goed bruikbaar, omdat die een veel indirectere relatie hebben met stikstof (namelijk: via hun leefgebied).
} 
planten ongunstig en voor een ander deel juist gunstig. Kwalificerende soorten kunnen verdwijnen door ongunstige abiotische omstandigheden, maar kunnen ook verdrongen worden

(weggeconcurreerd) door soorten die juist profiteren van stikstofdepositie. Een bekend voorbeeld is de vergrassing van heide waarbij een beperkt aantal grassoorten dominant wordt, waardoor minder concurrentiekrachtige soorten worden verdrongen. Daarom wordt in dit rapport ook aandacht besteed aan de zogenaamde 'verdringingssoorten'. Er is onderzocht of er een relatie is tussen de bedekking van deze verdringingssoorten en de stikstofdepositie. Daarbij is gekeken naar verdringingssoorten die ook kwalificeren voor het habitattype, de zogenaamde kwalificerende verdringingssoorten, en naar soorten die van buiten het habitattype komen en invasief zijn in het habitattype.

\section{B.2 Responscurven voor habitattypen op basis van kwalificerende soorten}

De respons van een habitattype op stikstofdepositie wordt hier afgeleid uit responscurven voor de bij het habitattype behorende kwalificerende soorten. De kans op voorkomen van een soort in relatie tot de stikstofdepositie wordt geschat op basis van vegetatieopnamen. Hiervoor wordt een logistisch regressiemodel gebruikt, waarbij gecorrigeerd wordt voor temperatuur, neerslag en bodemtype.

De gevolgde stappen worden hieronder in detail beschreven. Bij de keuzes die in deze verkenning zijn gemaakt, is steeds getracht een zo optimaal mogelijk gebruik van de gegevens te maken. De opgave was ten eerste om de 'ruis' te beperken die inherent is aan het werken met een grote hoeveelheid vegetatiegegevens die niet specifiek voor het doel van dit onderzoek zijn verzameld. Ten tweede is duidelijk dat de beschikbare dataset niet ideaal is samengesteld voor dit doel en dit kan 'bias', oftewel een systematische fout veroorzaken. Door het maken van selecties kunnen systematische fouten worden verminderd. In de navolgende paragrafen wordt beschreven hoe daarin keuzes zijn gemaakt.

\section{B.2.1 Materiaal en methoden voor het afleiden van responscurven}

\section{B.2.1.1 Kwalificerende soorten voor de habitattypen}

De lijst van kwalificerende soorten is opgesteld op basis van de principes en de database achter De Vegetatie van Nederland (Schaminée et al., 1995). Daarbij zijn twee criteria gehanteerd: (1) het percentage voorkomen van een soort, of kortweg de presentie, en (2) de trouwgraad van een soort, oftewel de mate waarin een soort gebonden is aan een plantengemeenschap. De trouwgraad kan berekend worden op basis van presentie, 'trouwPresentie', of op basis van de bedekking, 'trouwBedekking'. De laatste is berekend op basis van de gemiddelde bedekking van een soort in een plantengemeenschap. Kwalificerende soorten voldoen aan minimaal een van onderstaande vijf voorwaarden zoals berekend op basis van de database behorend bij De Vegetatie van Nederland (SynBioSys; https://www.synbiosys.alterra.nl/synbiosysnl):

1. presentie $\geq 10 \%$ én trouwPresentie $\geq \quad 7 \%$

2. presentie $\geq 10 \%$ én trouwBedekking $\geq \quad 7 \%$

3. presentie $\geq 4 \%$ én trouwPresentie $\geq \quad 30 \%$

4. presentie $\geq 2 \%$ én trouwPresentie $\geq \quad 85 \%$

5. presentie $\geq 85 \%$

De voorwaarden 1, 2 en 3 zijn gebaseerd op Smits et al. (2016). De voorwaarden 4 en 5 zijn toegevoegd om meer soorten en ontbrekende typische soorten te selecteren. Ook na de toevoeging van de extra regels ontbreken sommige typische soorten; deze zijn handmatig toegevoegd. Omdat de soortenlijst door middel van rekenregels is bepaald, zijn alle habitattypen nagelopen om te beoordelen of de geselecteerde soorten 'kwaliteit-indicerend' zijn, want de methode moet ertoe leiden dat uitspraken kunnen worden gedaan over afname van habitatkwaliteit. Daarbij zijn soorten afgevallen om de volgende redenen:

- Het is een boomsoort (zie beneden);

- De soort komt weliswaar veelvuldig voor in een habitattype, maar de soort is niet trouw;

- De soort is niet kenmerkend voor het type waar het om gaat;

- Het wel of niet voorkomen van de soort heeft geen invloed op de kwaliteit van het habitattype; 
- De soort is indicerend voor verstoring;

- De soort is een samenvoeging van twee of meer soorten, bijvoorbeeld Agrostis canina/vinealis oftewel Moeras-/Zandstruisgras.

Boomsoorten vormen een aparte categorie, omdat ze een lange levensduur hebben en daarom wellicht slechte indicatoren zijn voor de effecten van stikstofdepositie. Daarnaast zijn bomen vaak aangeplant en geven ze daarom niet altijd een goede indicatie van de natuurlijke situatie of hun natuurlijke verspreidingsgebied. Om de eventuele storende invloed van bomen te voorkomen, zijn zij niet meegenomen als kwalificerende soorten, ook niet in de bos-habitattypen. Een uitzondering is gemaakt voor een aantal wilgensoorten, omdat deze niet aangeplant worden, en voor boomsoorten die onderdeel zijn van de natuurlijke successie, bijvoorbeeld in droge heide. Voor de kwalificerende soorten per habitattype: zie Bijlage $8 \mathrm{~B}$.

\section{B.2.1.2 Indeling van habitattypen in structuurtypen}

Veel plantensoorten komen in verschillende habitattypen voor. Een voorbeeld is Kraaihei, die zowel in 'Duinheiden met Kraaihei (vochtig)' als in 'Vochtige duinvalleien (ontkalkt)' voorkomt. Omdat de responscurve voor een habitattype gebaseerd wordt op de responscurven van de bijbehorende kwalificerende soorten is het van belang om de responscurve voor een soort zo veel mogelijk specifiek voor een habitattype te maken. Een soort kan immers in verschillende habitattypen verschillend reageren op stikstofdepositie, onder andere als gevolg van andere soorten die aanwezig zijn en met de soort concurreren om voedsel en licht. Het is daarom wenselijk om aparte responscurven te schatten voor Kraaihei in 'Duinheiden met Kraaihei (vochtig)' en voor Kraaihei in 'Vochtige duinvalleien (ontkalkt)' en zo dus habitattype specifieke responscurven voor een soort te schatten. Dit kan, idealiter, bereikt worden door alle vegetatieopnamen die gebruikt worden om de responscurven te schatten, toe te wijzen aan een habitattype. Op Europese schaal is echter nog geen koppeling gelegd tussen vegetatieopnamen en Natura 2000-habitattypen. Het is wel mogelijk om opnamen in te delen in elf zogenaamde vegetatie structuurtypen, gegeven in Tabel 2, en tevens de habitattypen in te delen in dezelfde structuurtypen. Deze indeling is grover dan die in habitattypen, maar draagt bij om een zo specifiek mogelijke responscurve te schatten. Als een soort in meer dan één structuurtype voorkomt, wordt voor die soort per structuurtype een responscurve geschat. De Ruwheidsfactor in Tabel 2 wordt besproken in paragraaf B.2.1.5. De responscurve voor een habitattype, met een bepaald structuurtype, is dan gebaseerd op de geschatte responscurven voor hetzelfde structuurtype. De indeling van habitattypen in structuurtypen is gegeven in Bijlage 3. Merk op dat sommige habitattypen zijn gekoppeld aan twee structuurtypen. De koppeling van vegetatieopnamen en structuurtypen is beschreven in paragraaf B.2.1.4.

Tabel 2 Structurtypen met de bijbehorende afkortingen die gebruikt worden in figuren en de bijbehorende ruwheidsfactor.

\begin{tabular}{lll} 
Structuurtype & Afkorting & Ruwheidsfactor \\
Droog dwergstruweel & D-DS & laag \\
\hline Droog grasland & D-G & laag \\
\hline Droog loofbos & D-B & hoog \\
\hline Droog struweel & D-S & hoog \\
\hline Moeras & MOE & laag \\
\hline Nat dwergstruweel & N-DS & laag \\
\hline Nat grasland & N-G & laag \\
\hline Nat loofbos & N-B & hoog \\
\hline Stromend water & SWAT & laag \\
\hline Water & WAT & laag \\
\hline Zout & ZOU & laag \\
\hline
\end{tabular}

\section{B.2.1.3 Selectie van vegetatieopnamen, de EVA-database}

Responscurven voor soorten zijn geschat op basis van Europese vegetatieopnamen uit de EVA-database ('European Vegetation Archive', versie 2018; Chytrý et al., 1996), zie Figuur 21. Op deze database zijn verschillende selectiecriteria toegepast. In deze paragraaf wordt beschreven welke primaire selectiecriteria zijn gebruikt. Additionele selectiecriteria worden beschreven in volgende paragrafen. 
In dit project wordt het effect van stikstofdepositie op habitattypen in Nederland bestudeerd. Daarbij is het belangrijk om (1) opnamen te gebruiken met een zo groot mogelijk range aan stikstofdeposities om zo responscurven goed te kunnen schatten met name voor lage deposities, en (2) alleen die opnamen te gebruiken die verkregen zijn onder omstandigheden die vergelijkbaar zijn met Nederland. Criterium (1) impliceert dat niet alleen recente opnamen in Nederland, met hoge depositiewaarden, gebruikt moeten worden, maar dat het gebied en het jaar van opname uitgebreid moeten worden. Criterium (2) impliceert dat aan die uitbreiding restricties gesteld moeten worden.

Het gekozen compromis tussen (1) en (2) wordt gevormd door vegetatieopnamen vanaf 1950 te gebruiken in het gebied weergegeven in Figuur 22. Daarbij zijn alleen opnamen met een bekende lengte- en breedtegraad geselecteerd, zodat een koppeling met de stikstofdepositie en de hoogte boven zeeniveau van de opname mogelijk is. Het geselecteerde gebied bestaat uit de zogenaamde Atlantische zone, aangevuld met de rest van Duitsland en Frankrijk, het noordoosten van Spanje, de lage delen van Oostenrijk en Zwitserland en Scandinavië (met uitzondering van het deel boven de poolcirkel). Om de klimatologische verschillen met Nederland niet te groot te laten worden, zijn binnen dit gebied alleen opnamen beneden de $500 \mathrm{~m}$ hoogte geselecteerd (gebaseerd op het Europees dekkend hoogtemodel; U.S. Geological Survey, 1996). Door ook vroege opnamen, dat wil zeggen vanaf 1950, te gebruiken, worden meer opnamen met lage depositiewaarden geselecteerd. Dit heeft als nadeel dat de stikstofdepositie in het (verre) verleden minder goed bekend is.

De selectie van opnamen uit de EVA-database en koppeling met covariabelen is uitgevoerd in Python (Bijlage 9). Een automatisch gegenereerd verslag van de procedure is beschikbaar in Bijlage 9.

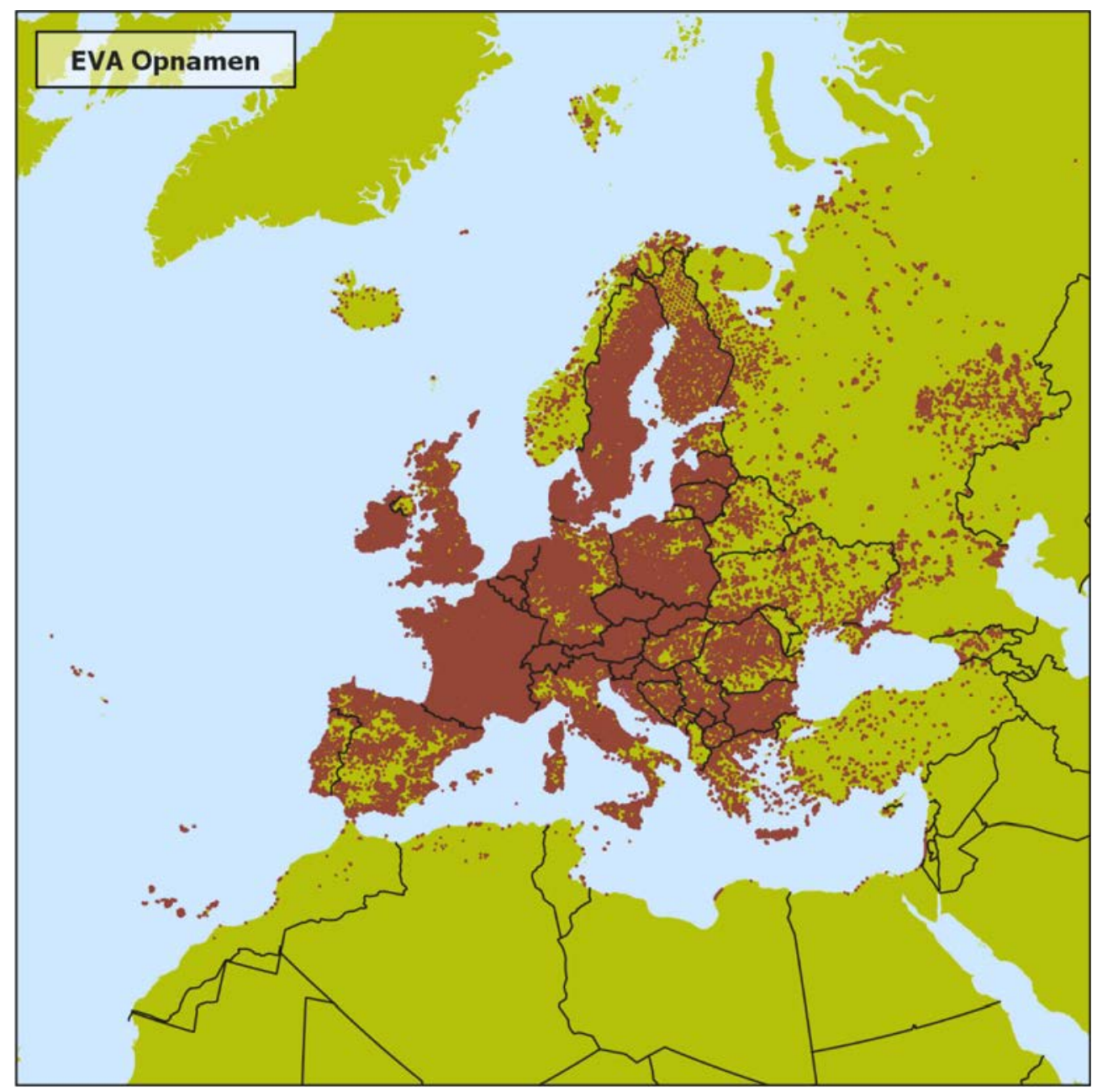

Figuur 21 Ligging van de vegetatieopnamen (bruine punten) in de EVA-database. Alleen opnamen uit het selectiegebied (zie Figuur 22) zijn geselecteerd. 


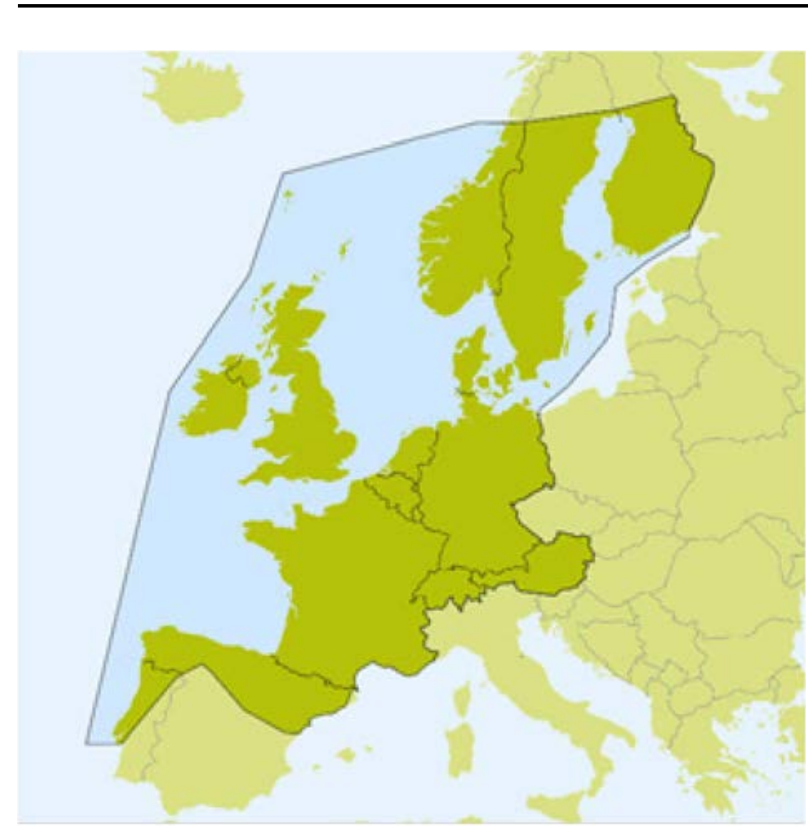

Figuur 22 Gebied waaruit de opnamen zijn geselecteerd voor het schatten van de responscurven, voor zover beneden 500m hoogte.

\section{B.2.1.4 Indeling van vegetatieopnamen in structuurtypen}

In paragraaf B.2.1.2 is beschreven dat responscurven voor een soort geschat worden op basis van vegetatieopnamen behorende tot één (soms twee) structuurtype(n). Daarvoor is het noodzakelijk om opnamen te koppelen aan structuurtypen. De indeling naar structuurtype is gebaseerd op EUNIStypen (European Nature Information System, EUNIS). Met behulp van expertregels (Chytrý et al., 2020) zijn alle geselecteerde opnamen in de EVA-database beoordeeld en hebben ze, daar waar mogelijk, een EUNIS-type toegewezen gekregen. Deze EUNIS-typen zijn vervolgens vertaald naar structuurtypen (Bijlage 4). Voor de opnamen die niet door de expertregels geclassificeerd konden worden, is gebruikgemaakt van een oude classificatie die al aan een deel van de opnamen was gekoppeld. Ook deze typen zijn vervolgens vertaald naar structuurtypen (Bijlage 5). Voor een beperkt aantal opnamen kan geen EUNIS-type toegekend worden; deze opnamen worden verder niet gebruikt.

\section{B.2.1.5 De stikstofdepositie per vegetatieopnamen}

Voor de stikstofdepositie is gebruikgemaakt van de schattingen zoals gedaan door het 'European Monitoring and Evaluation Programme' (www.emep.int), kortweg EMEP. Binnen dit programma wordt op een modelmatige, uniforme wijze de stikstofdepositie voor heel Europa geschat. EMEP maakt onderscheid tussen NOx- en NHy-concentraties in de lucht en ook in de daarvan afgeleide deposities. In principe kunnen separate responscurven voor beide vormen van stikstof worden geschat. Uit eerder onderzoek blijkt dat plantensoorten verschillend kunnen reageren op NOx- en NHy-concentraties in de lucht (er zijn dan ook verschillend kritische concentratieniveaus voor beide stoffen) en dat ook de verhouding tussen beide soorten van belang zou kunnen zijn (Stevens et al., 2011). Er zijn echter te weinig gegevens beschikbaar om verschillende kritische depositiewaarden voor beide stoffen af te leiden. In dit onderzoek zijn beide deposities daarom bij elkaar opgeteld tot de totale stikstofdepositie, zoals ook gebeurt bij de toepassing van KDW's en deze wordt uitgedrukt in $\mathrm{kg} \mathrm{N} / \mathrm{ha} / \mathrm{j}$. en soms in $\mathrm{kmol}$ $\mathrm{N} / \mathrm{h} / \mathrm{j}$. ( $\mathrm{kg} / \mathrm{ha} / \mathrm{j}$. kan verkregen worden door $\mathrm{kmol} / \mathrm{ha} / \mathrm{j}$. te vermenigvuldigen met 14 , het molecuulgewicht van stikstof).

Voor de periode 2000-2017 geeft EMEP de stikstofdepositie voor heel Europa per jaar op een grid van $0,1^{\circ} \times 0,1^{\circ}$ (Tsyro et al., 2018; 2019). De deposities zijn binnen EMEP gegenereerd met zogenaamde 'source receptor matrices'; deze worden onder meer toegepast in het evaluatie model GAINS (Amann et al., 2011). Voor de jaren vóór 2000 is de depositie alleen beschikbaar voor intervallen van vijf jaar $(1945,1950, \ldots, 1995)$ en voor een grover grid $\left(0,50^{\circ} \times 0,25^{\circ}\right)$. Deze vroegere deposities zijn gebaseerd op berekeningen zoals beschreven in Schöpp et al. (2003). Voor de periode 1945-2000 zijn de deposities van de tussenliggende jaren op het grid geschat door middel van lineaire interpolatie. 
De depositie behorende bij een opname wordt, op basis van de lengte- en breedtegraad, berekend via bilineaire interpolatie op het grid, zie Bijlage 7. Dit is uitgevoerd voor het jaar van de opname én voor de vier voorafgaande jaren, waarna het gemiddelde over deze vijf jaren aan de opname is toegekend. Eenjarige plantensoorten hebben vooral een relatie met de depositie die in hun groeijaar valt, terwijl langlevende soorten juist een relatie hebben met de depositie over een veel langere periode. Het vijfjaar gemiddelde is een redelijke middenweg. Dezelfde periode is gebruikt in het model PROPS (Wamelink et al., 2019).

Het is duidelijk dat de onzekerheid in de berekende depositie verder in het verleden relatief groot is. Dat wordt veroorzaakt doordat (1) deposities van voor 2000 zijn berekend met een ouder model, (2) deposities van voor 2000 beschikbaar zijn op een grover grid, wat de interpolaties onzekerder maakt, en (3) oudere depositieberekeningen zijn simpeler uitgevoerd, zeker voor 1960, én gebaseerd op minder data. De resulterende onzekerheid is momenteel niet in kaart gebracht.

De depositie behorende bij een opname is niet alleen afhankelijk van atmosferische omstandigheden ter plekke (zoals windsnelheid en richting), maar ook van zogenaamde ruwheidsfactoren, voornamelijk bepaald door de vegetatiebedekking. De ruwheidsfactoren worden in het EMEP MSC-W atmosferisch transportmodel verdisconteerd door gebruik te maken van een vegetatiekaart. Dit model berekent voor elke vegetatieklasse binnen een gridcel de depositie en middelt deze per gridcel. Behalve de gemiddelde depositie voor een gridcel wordt er ook een depositie berekend voor de klassen bos en (semi)natuurlijke vegetatie. Het EMEP MSC-W wordt beschreven door Simpson et al. $(2012,2014)$ en in de jaarlijkse updates van de EMEP-berekeningen (www.emep.int/mscw).

In theorie levert het gebruik van de ruwheidsfactor een beter bij de vegetatie en opname passende depositie. Op opnameniveau zijn er verschillen tussen de ongecorrigeerde en voor ruwheid gecorrigeerde depositie. Voor opnamen met een hoge ruwheidsfactor worden de verschillen weergegeven in Figuur 23 met duidelijk hogere deposities als er rekening wordt gehouden met de ruwheid. Voor opnamen met een lage ruwheidsfactor, zie Figuur 24, zijn de verschillen kleiner, waarbij opvalt dat lage ongecorrigeerde deposities vaak nog lager worden na correctie voor ruwheid. In een eerdere analyse in dit project, met geschatte responscurven voor soorten zonder uitsplitsing naar structuurtype, zijn de responscurven met ongecorrigeerde en gecorrigeerde depositie met elkaar vergeleken. Daaruit bleek dat er kleine verschillen waren. De depositie op basis van de ruwheidsfactor is gebruikt, omdat deze beter aansluit bij de lokale situatie en vooral ook bij de vegetatie van het habitattype.
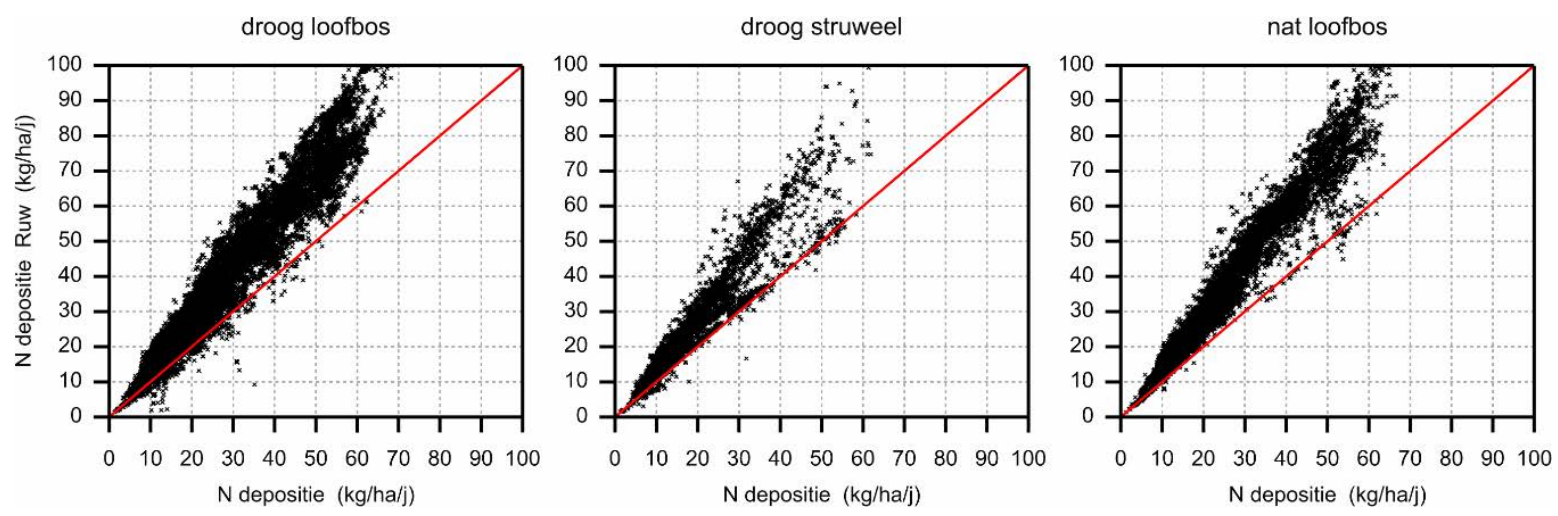

Figuur 23 Stikstofdepositie gecorrigeerd voor de ruwheidsfactor van een opname versus de ongecorrigeerde stikstofdepositie voor de structuurtypen met een hoge ruwheidsfactor. De rode lijn representeert een gelijke depositie met en zonder ruwheidsfactor. 

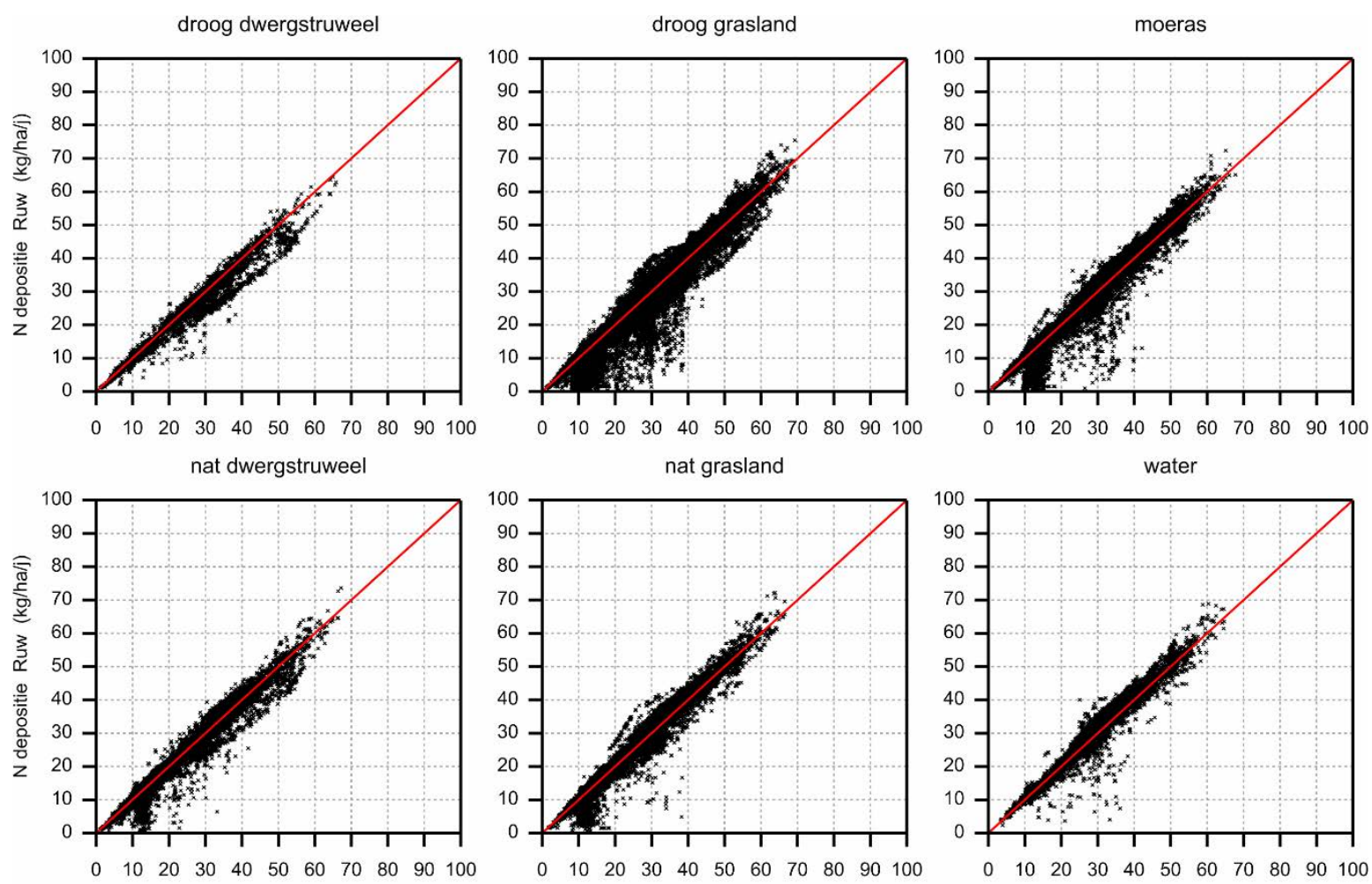

zout

$\mathrm{N}$ depositie $(\mathrm{kg} / \mathrm{ha} / \mathrm{j})$

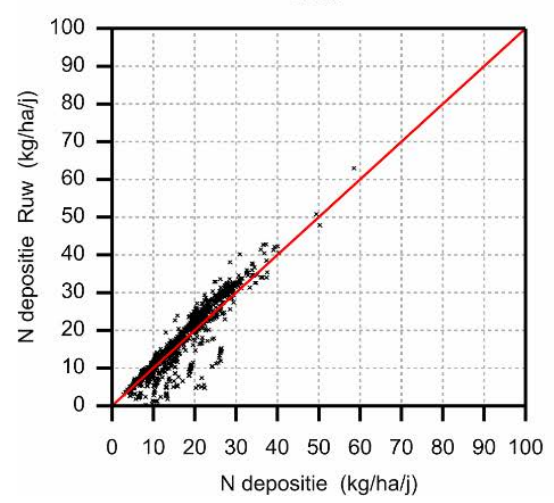

Figuur 24 Stikstofdepositie gecorrigeerd voor de ruwheidsfactor van een opname versus de ongecorrigeerde stikstofdepositie voor de structuurtypen met een lage ruwheidsfactor. De rode lijn representeert een gelijke depositie met en zonder ruwheidsfactor.

De ruimtelijke visualisatie van de voor ruwheid gecorrigeerde stikstofdepositie (EMEP-resultaat) per opname is gegeven in Figuur 25. Daarbij is de depositie van jongere opnamen over die van oudere opnamen geplot, zodat naastliggende deposities uit verschillende jaren kunnen komen. De figuur is dus geen weergave van de actuele verschillen in depositie. Het blijkt dat de vegetatieopnamen met de hoogste deposities voorkomen in Nederland, België en delen van Duitsland. Figuur 26 geeft het aantal vegetatieopnamen per jaar waarvoor de depositie beschikbaar is. Vóór 1970 zijn er relatief weinig opnamen beschikbaar in de EVA-database, terwijl de meeste opnamen van na 2000 zijn. Figuur 27 laat zien dat de meeste deposities in de categorieën tussen 7.5 en $20 \mathrm{~kg} \mathrm{~N} / \mathrm{ha} / \mathrm{j}$. liggen. Zeer hoge waarden, groter dan $50 \mathrm{~kg} \mathrm{~N} / \mathrm{ha} / \mathrm{j}$., komen sporadisch voor. In een beperkt aantal gevallen (1540 van de 563754 opnamen, $0,27 \%$ ) is de geïnterpoleerde depositie nul of zelfs negatief; dit artefact heeft geen invloed gehad op de resultaten, omdat deze opnamen zijn verwijderd. Negatieve deposities kunnen ontstaan door te grote extrapolatie aan de rand van het gebied waar het model de deposities voor schat. 


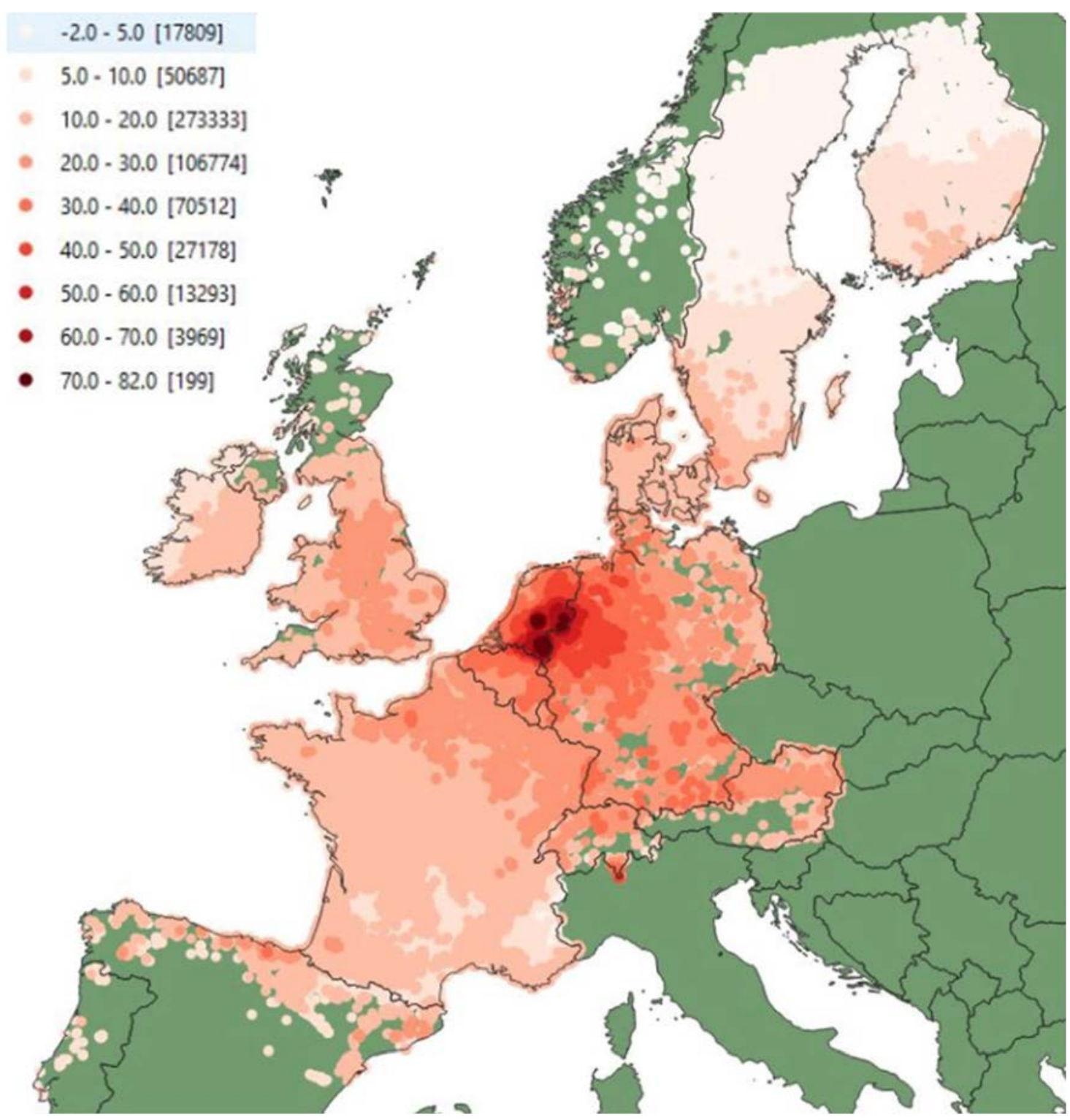

Figuur 25 Met EMEP gemodelleerde vijfjarige gemiddelde stikstofdepositie $(\mathrm{kg} / \mathrm{ha} / \mathrm{j}$.) na correctie voor de ruwheidsfactor voor de geselecteerde vegetatieopnamen in de periode 1950-2018. Naast elkaar liggende punten kunnen uit een verschillende periode komen. Als op dezelfde plek meerdere opnamen beschikbaar zijn, dan is de hoogste depositie weergegeven. De verschillende kleuren representeren depositieklassen, met tussen haken het aantal opnamen. Voor de groene delen zijn geen opnamen beschikbaar (of ze liggen buiten het selectiegebied).

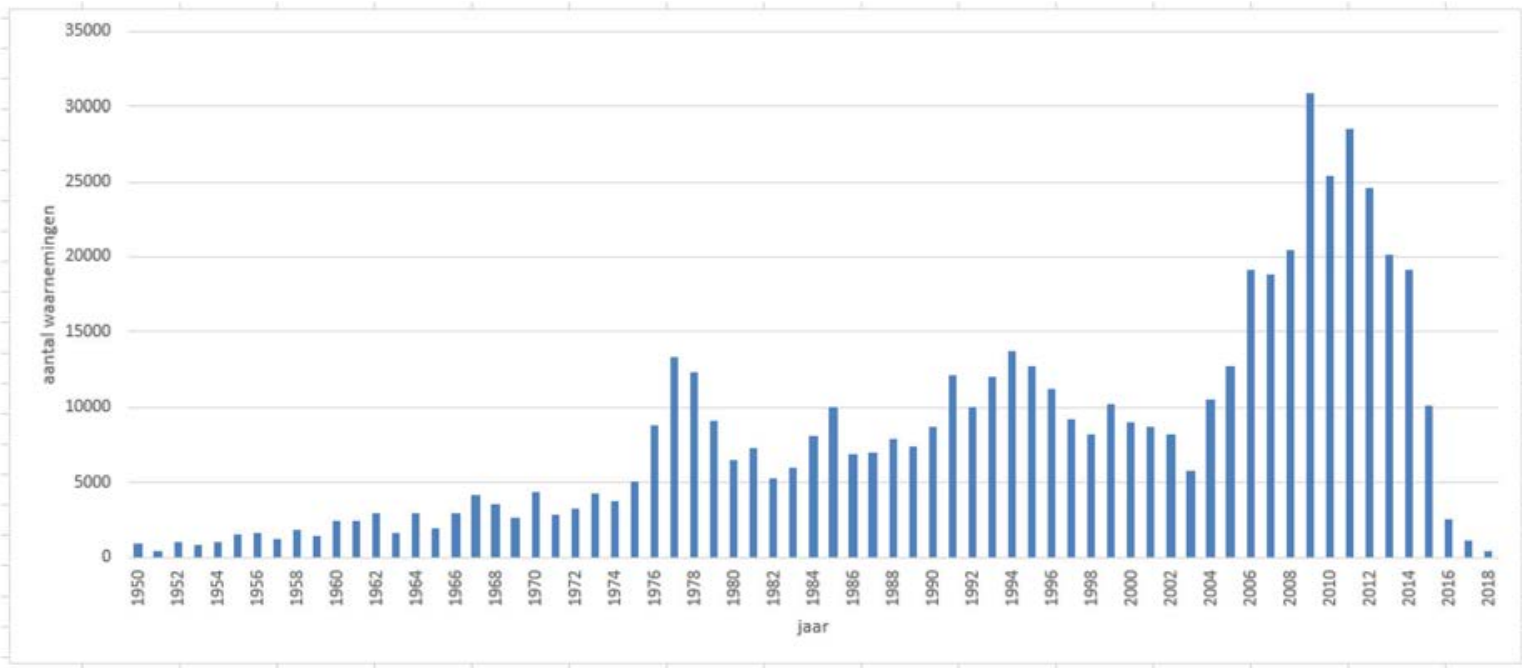

Figuur 26 Aantal vegetatieopnamen per jaar. 


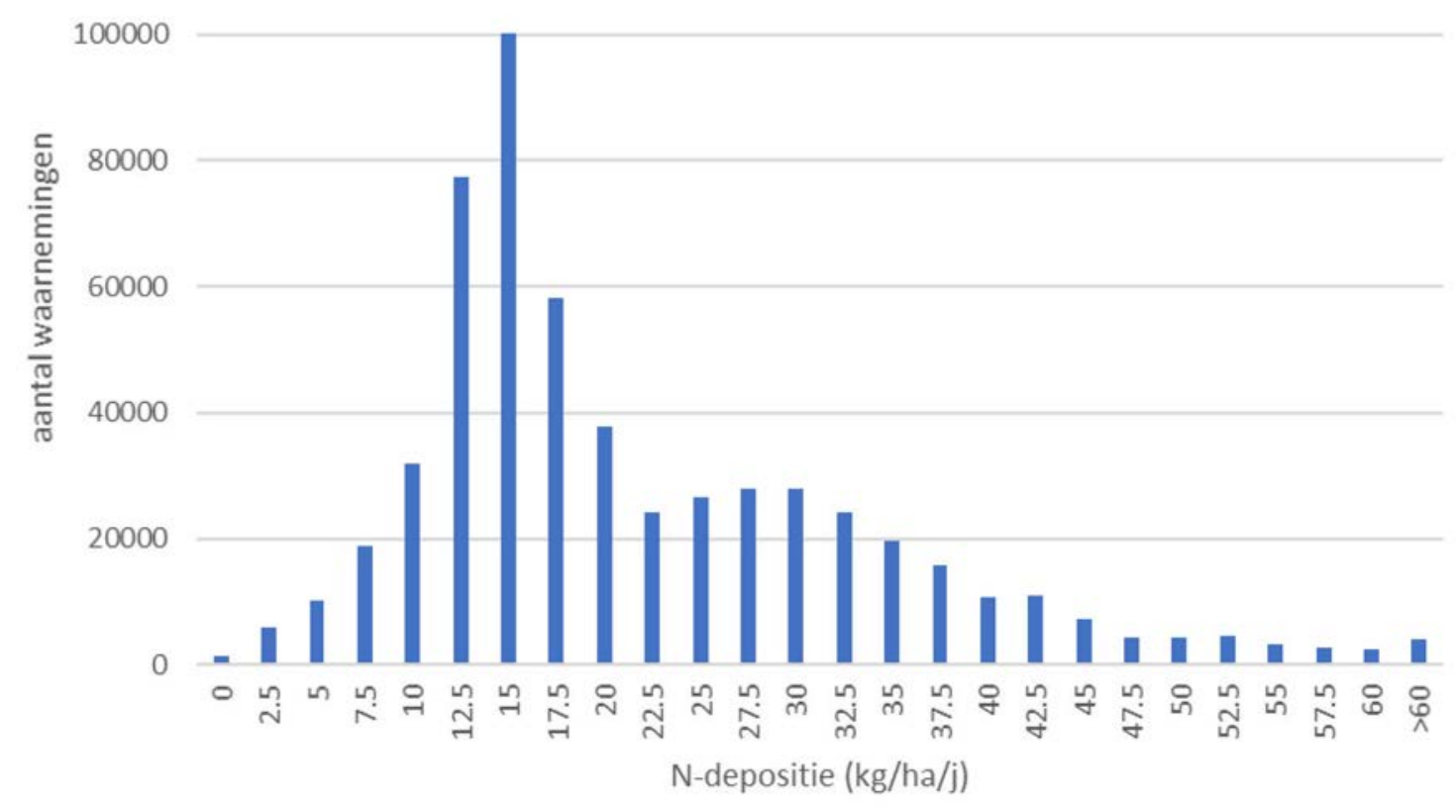

Figuur 27 Aantal vegetatieopnamen per stikstofdepositieklasse van 2,5 $\mathrm{kg} \mathrm{N/ha/j}$.

\section{B.2.1.6 Temperatuur en neerslag voor vegetatieopnamen}

In het logistische regressiemodel voor het schatten van de responscurven wordt gecorrigeerd voor temperatuur en neerslag. Deze zijn voor de vegetatieopnamen verzameld op basis van de gegevens van weerstations (Figuur 28). Daarvoor is gebruikgemaakt van de E-OBS-dataset van het EU-FP6project-UERRA (www.uerra.eu), de Copernicus 'Climate Change Service' en data van het ECA\&Dproject (ecad.eu, Cornes et al., 2018).

Voor elke vegetatieopname zijn de temperatuur- en neerslagrasters geprikt op basis van de opnamecoördinaten in het jaar van opname plus de vier voorafgaande jaren. Het gemiddelde van deze vijf temperatuur-/neerslagwaarden is toegekend aan de opname. Dit is analoog aan de berekening van de depositie en de berekening in PROPS (Wamelink et al., 2019). Een ruimtelijke visualisatie van de zo verkregen gemiddelde jaartemperatuur en neerslag per jaar is gegeven in Figuur 29 en Figuur 30. 


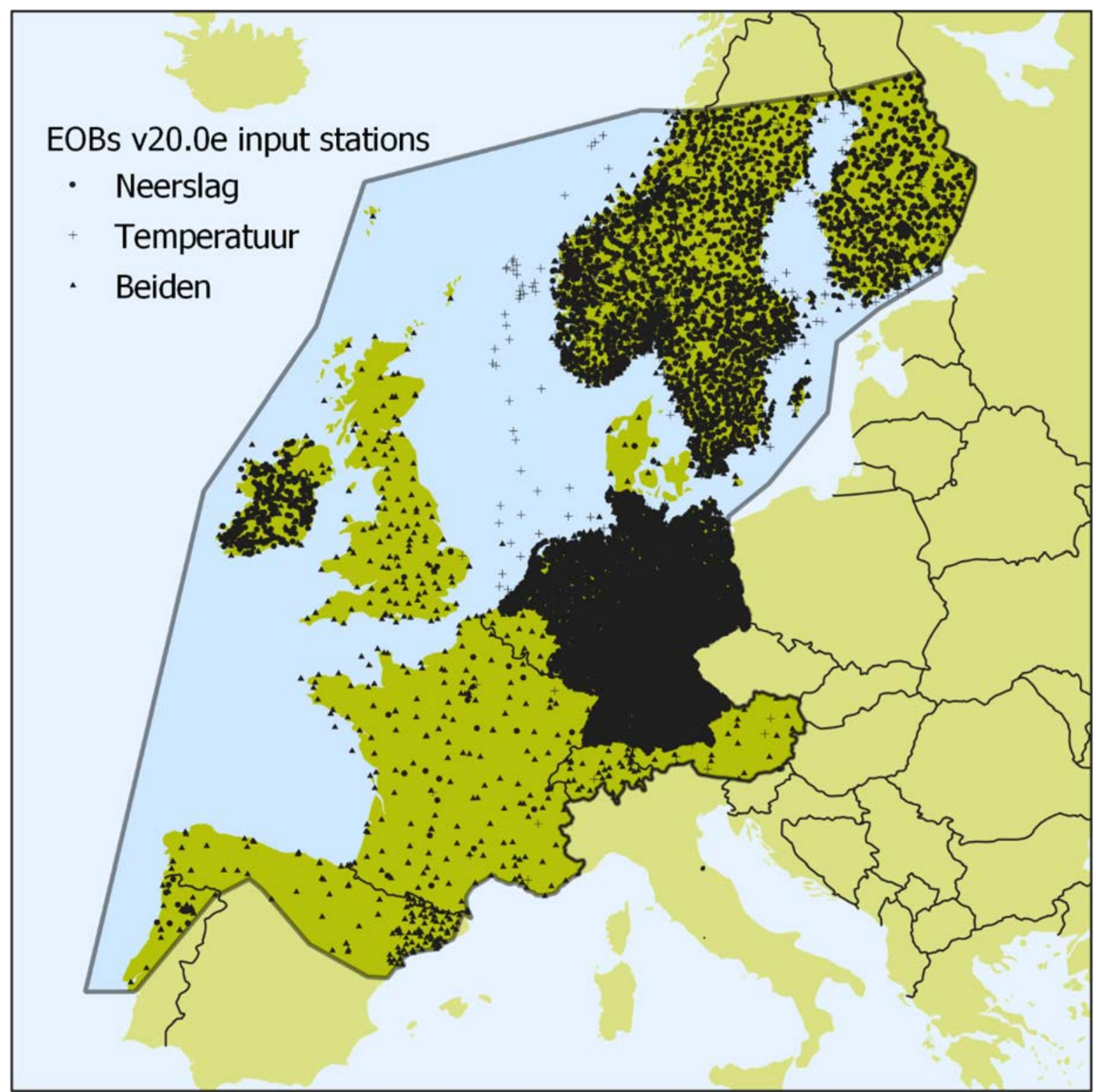

Figuur 28 Weerstations die gebruikt zijn voor het schatten van de neerslag en de temperatuur per vegetatieopname in het groot Atlantische gebied. 


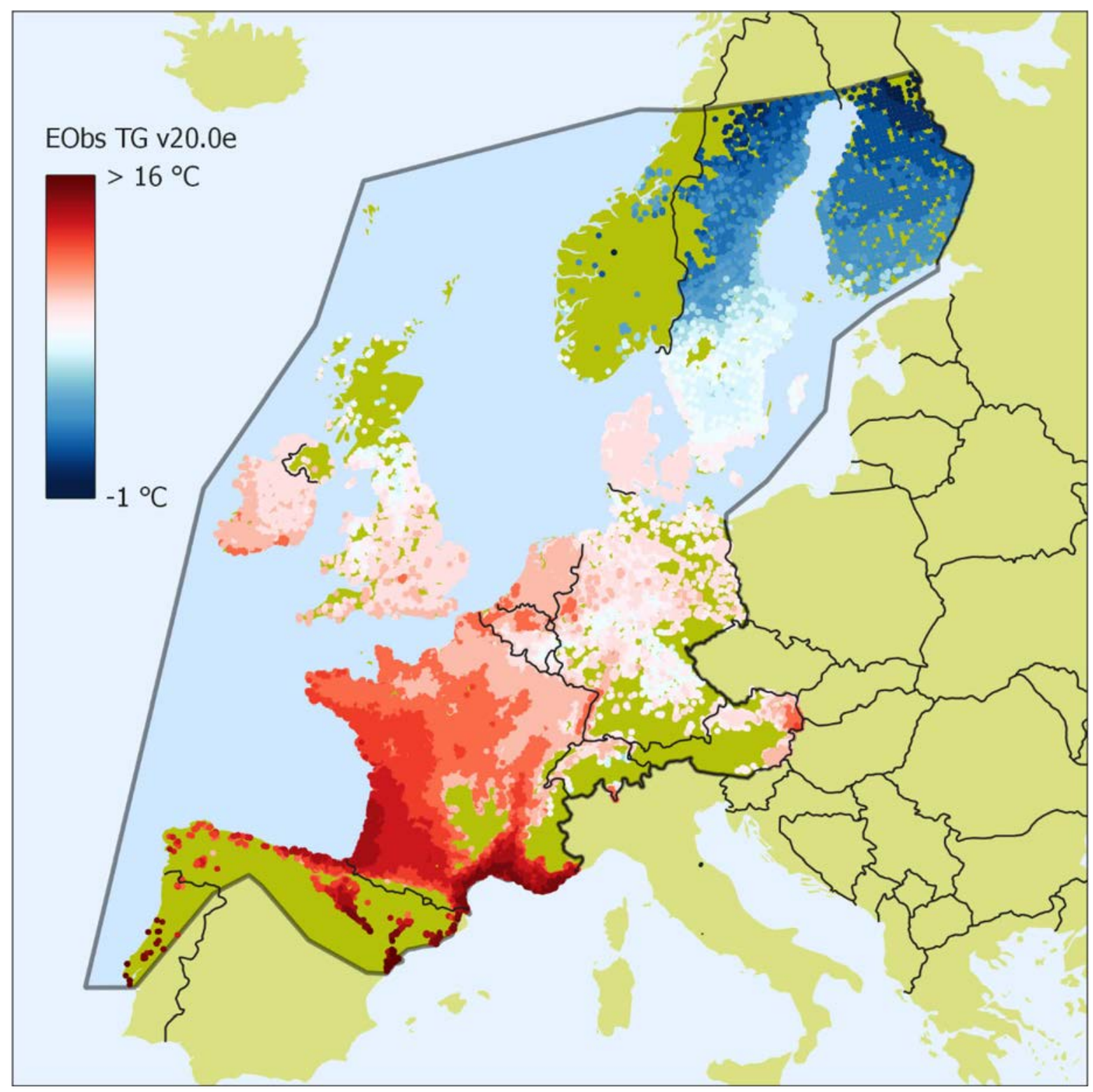

Figuur 29 Gemiddelde jaartemperatuur behorend bij de vegetatieopnamen. De donkergroene delen binnen het selectiegebied bevatten geen geselecteerde vegetatieopnamen. 


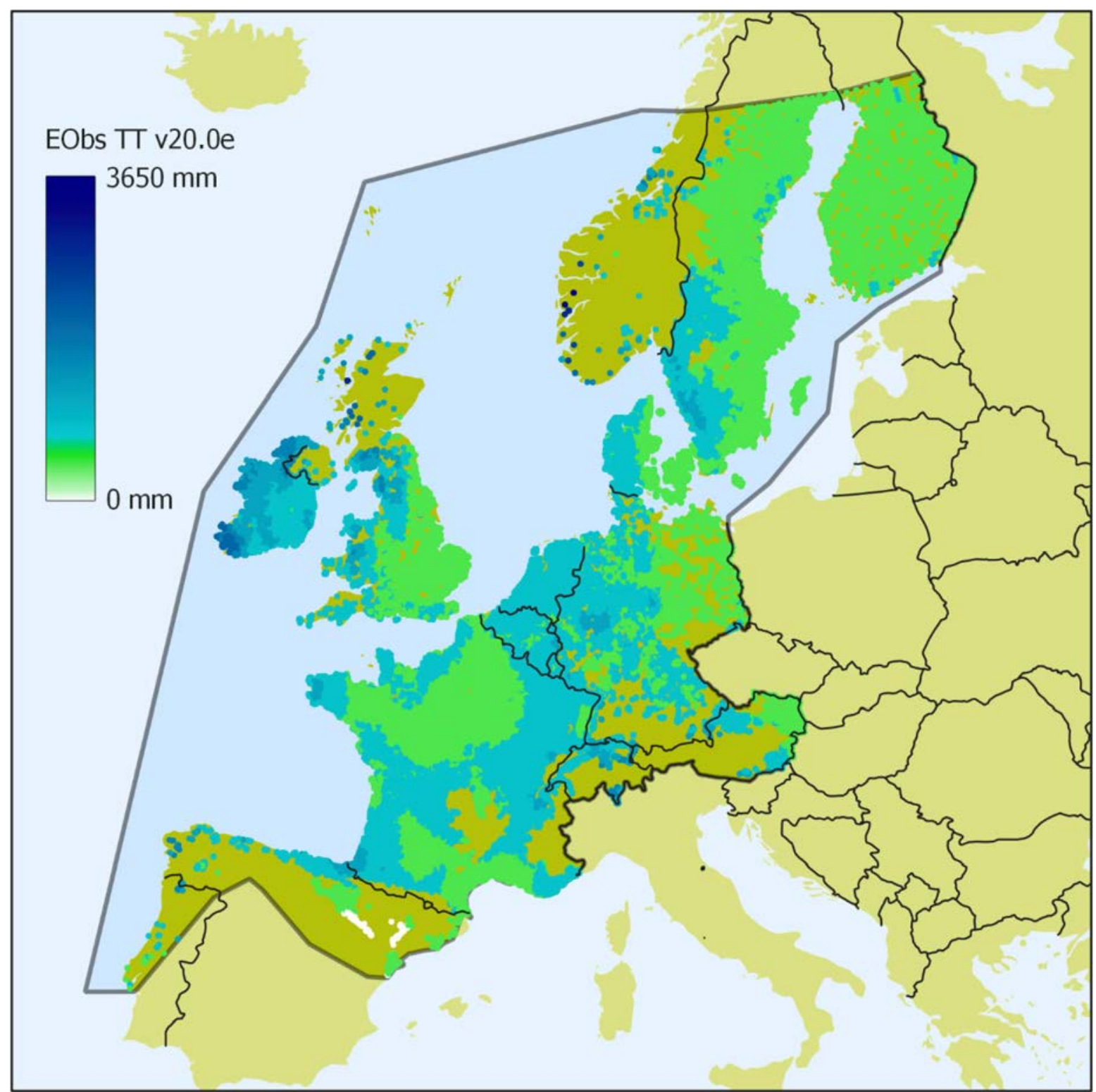

Figuur 30 Gemiddelde neerslagsom per jaar (in $\mathrm{mm}$ ) behorend bij de vegetatieopnamen. De donkergroene delen binnen het selectiegebied bevatten geen geselecteerde vegetatieopnamen.

In het logistische regressiemodel voor het schatten van de responscurven worden temperatuur en neerslag gebruikt als covariabelen. Om een responscurve voor Nederland te verkrijgen, alleen als functie van de depositie, moet in het geschatte regressiemodel een waarde ingevuld worden voor de temperatuur en de neerslag. Daarvoor is het gemiddelde genomen over de periode 2007-2017 voor De Bilt, respectievelijk $10,6{ }^{\circ} \mathrm{C}$ en $876 \mathrm{~mm}$, zie Tabel 3.

Tabel 3 Gemiddelde temperatur en neerslag voor de Bilt over de periode 2007-2017.

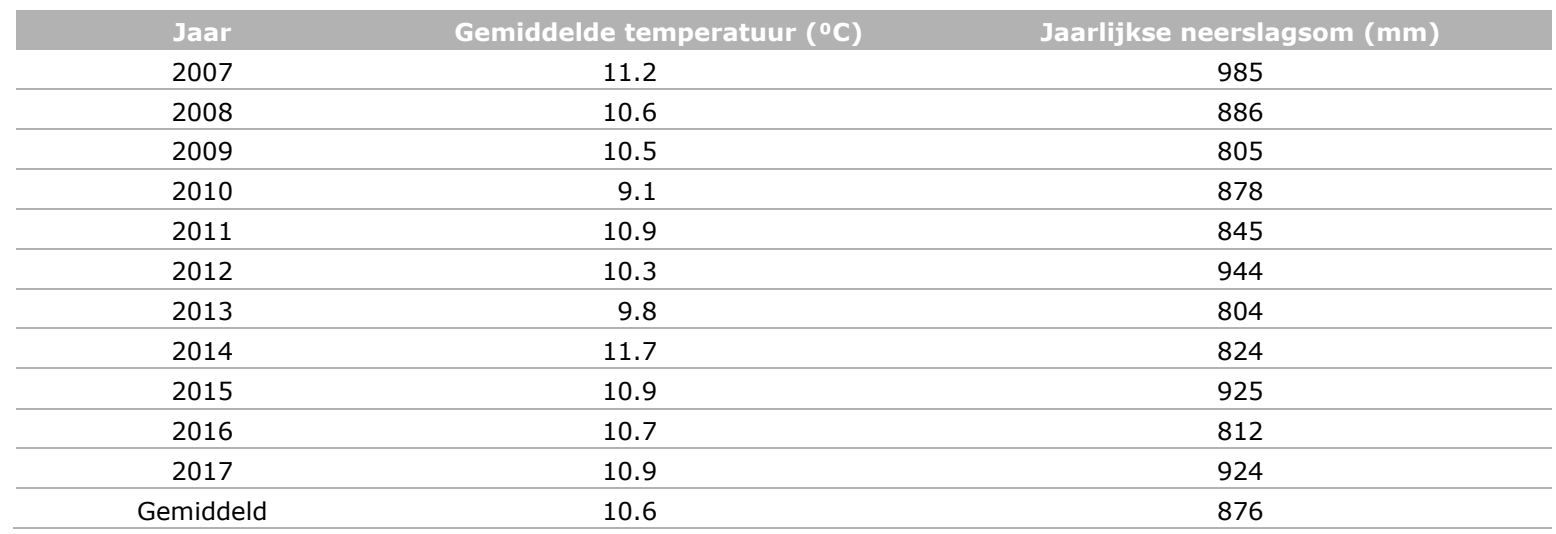




\section{B.2.1.7 Bodemtype behorend bij vegetatieopnamen}

In het logistische regressiemodel voor het schatten van de responscurven wordt gecorrigeerd voor bodemtype. Aan de hand van de coördinaten van elke opname is het bodemtype vastgesteld op basis van de Bodematlas van Europa (Jones et al., 2005; World Reference Base for Soil Resources). Vegetatieopnamen op bodemtypen die niet in Nederland voorkomen, zijn niet gebruikt. De overgebleven bodemtypen zijn samengevoegd tot negen hoofdtypen (Tabel 4, Figuur 31). Daarvan worden de typen 'rotsig' en 'menselijk' (bebouwing en verharding) niet gebruikt. De weinige opnamen op 'löss' zijn bij 'zand' gevoegd en bodem type 'zout' is toegevoegd aan 'klei'. Merk op dat zout wel wordt onderscheiden via de vegetatiestructuurtypen, waar zout een aparte categorie is. Het type water bevat ook weinig opnamen, maar die is niet geschrapt; het kan hierbij ook om oevers gaan. Daarmee resteren er vijf vereenvoudigde categorieën: zand, klei, jonge bodem, veen en water.

In het logistische regressiemodel wordt het bodemtype gebruikt als covariabele. Om één enkele curve voor Nederland te verkrijgen, alleen als functie van de depositie, is er gewogen gemiddeld over de bodemtypen naar rato van het aantal opnamen voor de verschillende bodemtypen in Nederland voor de betreffende dataset. Indien het aantal opnamen voor een soort in Nederland kleiner is dan 100, dan is gewogen naar het aantal opnamen voor de verschillende bodemtypen in Europa.

Tabel 4 Bodemtypen volgens Jones et al. (2005) en hun vertaling naar de grondsoorten zand, klei en veen, jonge bodem (jong) en water.

\begin{tabular}{|c|c|c|}
\hline Type & Korte omschrijving & $\begin{array}{l}\text { Vereenvoudigd naar } \\
\text { grondsoort }\end{array}$ \\
\hline Podzol & Podzol, inzijging en uitspoelzone & zand \\
\hline Histosol & Veen & veen \\
\hline Gleysol & $\begin{array}{l}\text { Gley, nat, onder invloed van grondwater in NL zeeklei. In de Nederlandse } \\
\text { bodemclassificatie worden ze ingedeeld bij de moerige podzolgronden, de moerige } \\
\text { eerdgronden en de hydrovaaggronden }\end{array}$ & klei \\
\hline Fluvisol & $\begin{array}{l}\text { Overstroomde bodems langs rivieren, ook polders, echter ook katteklei (zeer } \\
\text { zuur) }\end{array}$ & klei \\
\hline Cambisol & $\begin{array}{l}\text { Jonge bodems, ontstaan door wind, water of verweerd rots dat naar beneden is } \\
\text { gerold }\end{array}$ & jonge bodem \\
\hline Phaeozem & $\begin{array}{l}\text { Organische bodems, kalkloos Phaeozems zijn gevormd in eolische afzettingen als } \\
\text { löss, morene of andere niet geconsolideerde, voornamelijk basische materialen }\end{array}$ & zand (löss) \\
\hline Chernozem & $\begin{array}{l}\text { Organische bodems, kalkloze Phaeozems zijn gevormd in eolische afzettingen als } \\
\text { löss, morene of andere niet geconsolideerde, voornamelijk basische materialen }\end{array}$ & zand (löss) \\
\hline Umbrisol & $\begin{array}{l}\text { Zure bodems met sterke inzijging, met een donkere bovengrond (A-horizont) en } \\
\text { waarin zich zoveel organische stof heeft geaccumuleerd in de minerale bodem dat } \\
\text { dit de eigenschappen en het gebruik van de bodem duidelijk beïnvloedt }\end{array}$ & zand \\
\hline Solonchak & Zoute bodems waar water via kwel voor sterke verzilting zorgt & zand \\
\hline Solonetz & $\begin{array}{l}\text { Zoute kleibodems, door voormalige zout- en kleiafzettingen, dus niet huidige } \\
\text { kwelders etc. }\end{array}$ & klei \\
\hline Luvisol & Kleiachtige bodems & klei \\
\hline Acrisol & $\begin{array}{l}\text { Grof zand, sterk verweerde zure bodem met een lage basenverzadiging. Het } \\
\text { onderliggende moedermateriaal is vaak een sterk verweerde klei op Pleistoceen of } \\
\text { ouder zuur gesteente }\end{array}$ & klei \\
\hline Marsh & Moeras & veen \\
\hline Gypsisol & $\begin{array}{l}\text { Kalkrijke zandgronden, gipsgrond, lokaal in Spanje (woestijngrond) in } \\
\text { ongeconsolideerde alluviale, colluviale of eolische afzettingen van basisch } \\
\text { verweringsmateriaal }\end{array}$ & zand \\
\hline
\end{tabular}




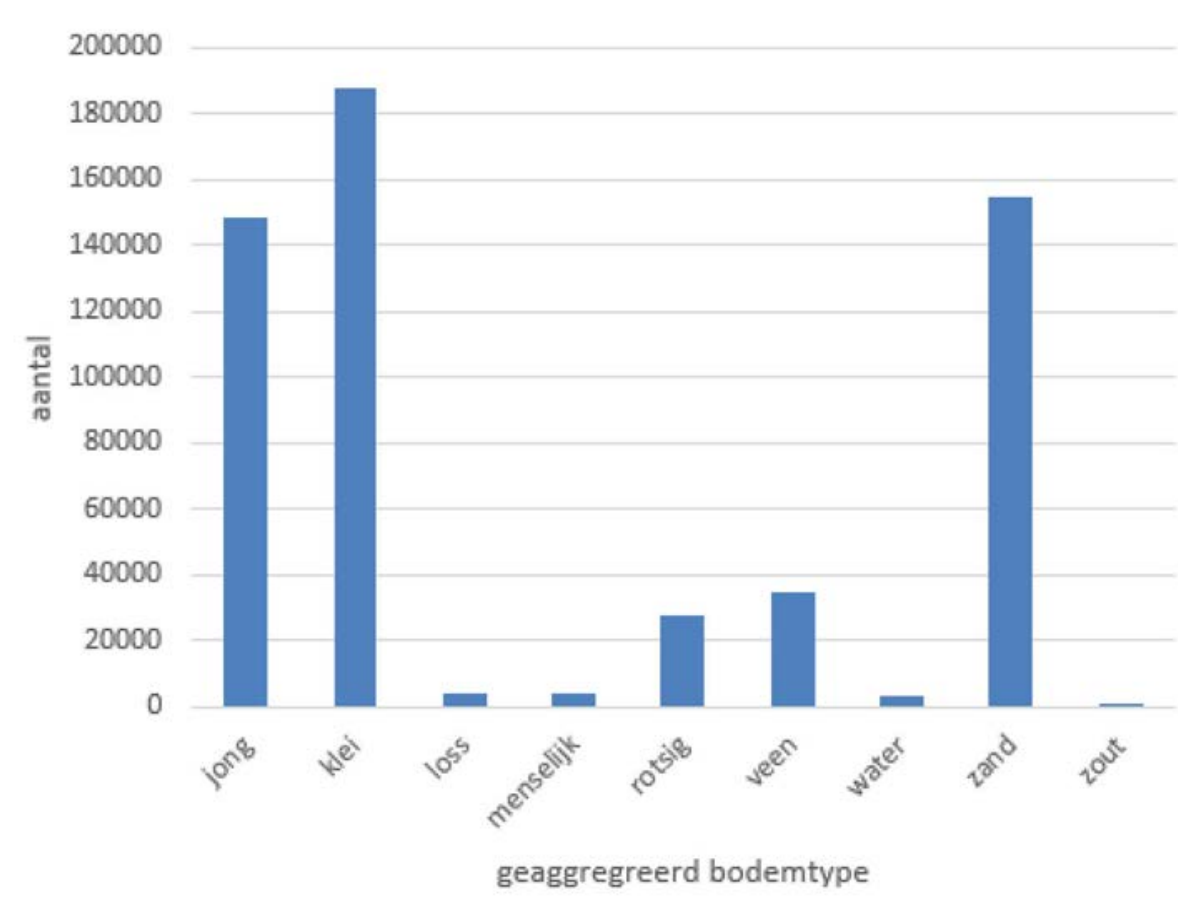

Figuur 31 Aantal vegetatieopnamen uitgesplitst naar negen vereenvoudigde bodemtypen in het selectiegebied; zout is toegevoegd aan klei en löss aan zand, menselijk en rotsig zijn niet gebruikt en jong staat voor jonge bodems.

\section{B.2.1.8 Constructie van datasets via het verspreidingsgebied van een soort}

Voor het schatten van responscurven, dat wil zeggen de kans op voorkomen van een soort als functie van de depositie, zijn behalve positieve waarnemingen van een soort in vegetatieopnamen (gecodeerd door enen) ook vegetatieopnamen nodig waarin de soort niet voorkomt (gecodeerd door nullen). In principe zouden alle geselecteerde opnamen gebruikt kunnen worden om de responscurve te schatten. De curve representeert dan de kans op voorkomen in het selectiegebied. Het nadeel van deze benadering is echter dat dan mogelijk opnamen gebruikt worden die ver buiten het verspreidingsgebied van een soort liggen, met andere natuurlijke en klimatologische omstandigheden dan waar de soort voorkomt. Voor de responscurve van zoutminnende soorten worden dan bijvoorbeeld ook nulwaarnemingen van buiten de kustregio's, of voor soorten die met name in warmere omstandigheden voorkomen, zouden ook nulwaarnemingen in de Scandinavische landen worden gebruikt. Dergelijke nulwaarnemingen, in opnamen waar de soort niet kan voorkomen, zijn ongewenst bij het afleiden van de responscurve, omdat ze geen recht doen aan het verspreidingsgebied van de soort. Een afwezigheid in een opname bij een bepaald depositieniveau wordt dan ten onrechte gecorreleerd aan dat depositieniveau, terwijl de werkelijke reden van de afwezigheid is dat de soort ter plekke van nature niet voorkomt. Er is dus een methode nodig die rekening houdt met het verspreidingsgebied van een soort.

Helaas zijn er geen verspreidingskaarten voor alle soorten digitaal beschikbaar. Daarom zijn de volgende twee stappen doorlopen om het verspreidingsgebied van een soort vast te stellen: (1) door een globale afbakening op basis van vegetatieopnamen waar een soort in voorkomt (het selectiegebied), en (2) door per vegetatieopname waar de soort voorkomt een veel specifieker gebied vast te stellen.

Om een selectie te maken, wordt rond elke opname waarin de soort voorkomt een cirkel getrokken. Alleen opnamen zonder de soort die binnen die cirkel liggen, tellen mee als nulwaarnemingen. Daarbij is de grootte van de cirkel wel van belang. Want hoe groter de cirkel, hoe meer opnamen worden geselecteerd en tevens hoe groter de range van stikstofdepositie kan zijn, wat belangrijk is voor het kunnen bepalen van responscurven (zie ook Deel $\mathrm{A}$ ). Bij te grote cirkels worden echter ook relatief veel opnamen geselecteerd waar de soort niet kán voorkomen. Een goed voorbeeld hiervan zijn de soorten van kwelders: bij een cirkelgrootte van $100 \mathrm{~km}$ worden veel opnamen als nulwaarnemingen toegevoegd van buiten de kustregio's, waar een kweldersoort van nature niet voorkomt. Figuur 32 
geeft een voorbeeld van het effect van de cirkelgrootte op het geschatte verspreidingsgebied van Struikhei. Naarmate de cirkel groter wordt, wordt het geschatte verspreidingsgebied groter en worden gebieden aan elkaar gekoppeld tot één groot verspreidingsgebied. Mede op basis van de figuren voor Struikhei en Kraaihei is gekozen voor een cirkelgrootte van $25 \mathrm{~km}$. De geselecteerde gebieden passen dan het best bij de daadwerkelijke verspreidingsgebieden van de soorten. Bij cirkels van 50 en $100 \mathrm{~km}$ zouden de cirkels tot een groot gebied fuseren, inclusief plekken waar de soort (waarschijnlijk) niet kan voorkomen. Bij cirkels van $10 \mathrm{~km}$ zou een te versnipperd patroon ontstaan, waardoor relatief weinig nulwaarnemingen worden meegenomen, wat mogelijk zou leiden tot het overschatten van de kans op voorkomen van zeldzame soorten.

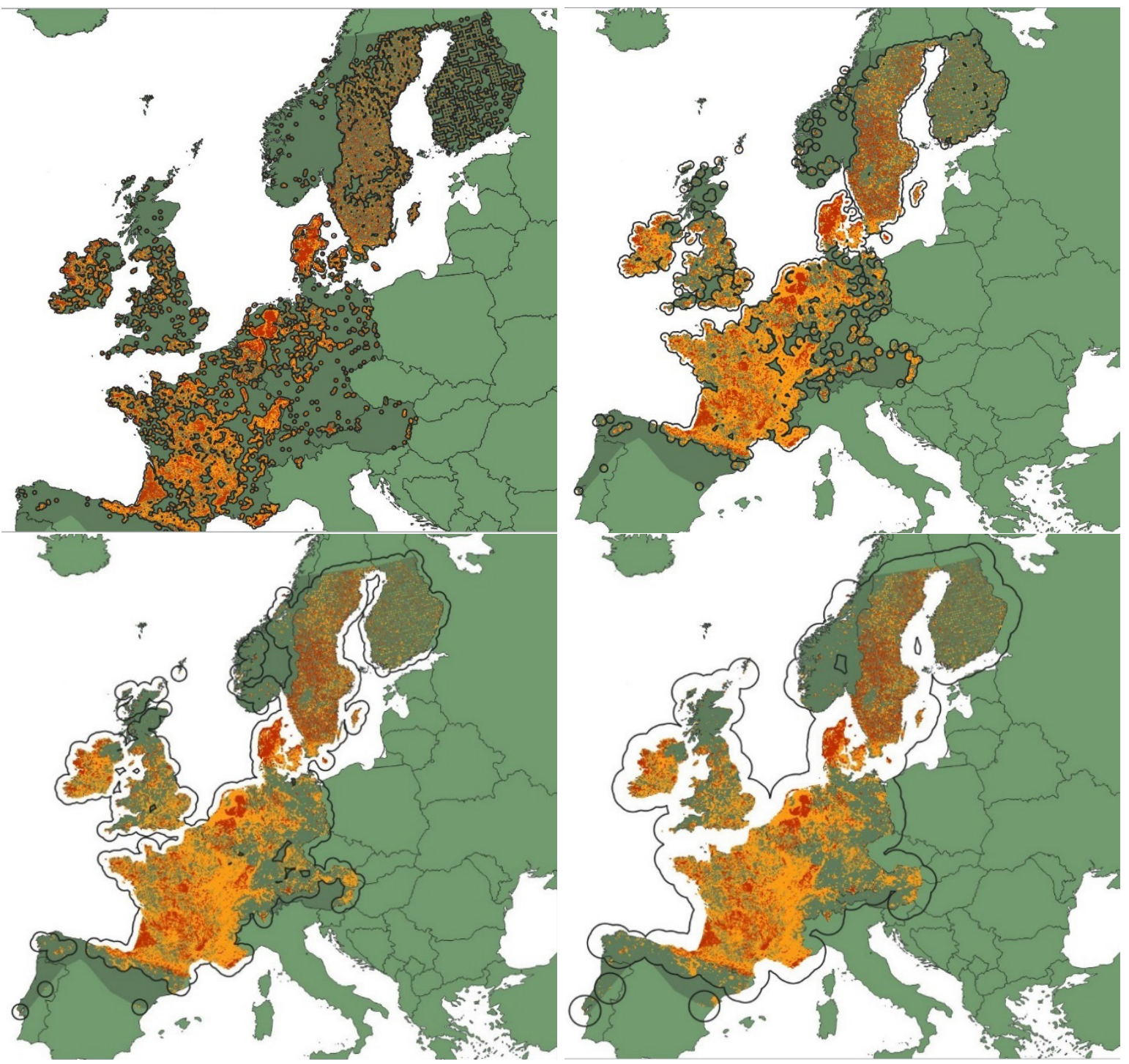

Figuur 32 Geschat verspreidingsgebied voor Calluna vulgaris (Struikhei) op basis van cirkels getrokken rondom een vegetatieopname met deze soort. Linksboven: cirkelgrootte $10 \mathrm{~km}$, rechtsboven: $25 \mathrm{~km}$, linksonder: $50 \mathrm{~km}$ en rechtsonder: $100 \mathrm{~km}$. Donkerrode punten zijn opnamen met Struikhei (de enen), oranje punten opnamen zonder Struikhei (de nullen) die binnen de zoekcirkel meegenomen kunnen worden als nulwaarnemingen (mits behorend tot hetzelfde vegetatiestructuurtype).

In aanvulling op het verspreidingsgebied, dat gedefinieerd wordt door cirkels van $25 \mathrm{~km}$ rond opnamen waar een soort in voorkomt, wordt ook rekening gehouden met het bij het habitattype behorende vegetatiestructuurtype zoals beschreven in paragraaf B.2.1.2. Bijlage 6 bevat een gedetailleerde beschrijving van de selectie van vegetatieopnamen voor het schatten van een responscurve voor een soort per structuurtype. 
Er zijn in totaal 2735 soort/structuurtypecombinaties waarvoor een responscurve gewenst is. Er worden echter alleen curven geschat indien er minimaal 100 opnamen zijn waar de soort in het structuurtype voorkomt. Met die voorwaarde blijven er 2254 combinaties over. Dat impliceert dat er voor 481 combinaties geen curve wordt geschat én dat deze combinaties ook niet meedoen in het berekenen van een curve per habitat.

\section{B.2.1.9 Bepaling van responscurven voor soorten}

Per soort/structuurtypecombinatie wordt de kans op aanwezigheid gemodelleerd als functie van de stikstofdepositie waarbij gecorrigeerd wordt voor temperatuur, regen en bodemtype. Omdat het 0/1waarnemingen betreft, wordt hiervoor logistische regressie gebruikt, waarbij de relatie met stikstofdepositie gemodelleerd wordt door een smoothing spline met twee graden van vrijheid (Hastie \& Tinshirani, 1990):

$$
\operatorname{logit}(\pi)=\alpha+\beta_{1} \text { Regen }+\beta_{2} \text { Temperatuur }+\beta_{3} \text { Regen } \times \text { Temperatuur }+ \text { Bodem }+ \text { Spline }(\mathrm{N} \text {-depositie; } 2)
$$

Voor de relatie met stikstofdepositie zou ook voor een lineair of kwadratisch model gekozen kunnen worden. Een spline is echter flexibeler en wordt veel gebruikt in het modelleren van responscurven (zie bijvoorbeeld Wamelink et al., 2005). Met het aantal vrijheidsgraden (DF) van de spline kan de flexibiliteit van de aangepaste curve worden ingesteld, meer DF geeft flexibelere ('wildere') curven. Vanwege het zeer grote aantal waarnemingen geeft een spline met meer DF in het algemeen een statistisch significant betere curve. Splines met meer DF bewegen echter mee met de mogelijk grote verschillen in kans op voorkomen bij naastliggende depositiewaarden, welke veroorzaakt kunnen worden door bias in de gebruikte dataselectie. Daarom is gekozen voor een beperkt flexibele spline met $2 \mathrm{DF}$; deze zou een goed beeld moeten geven van het verloop van de respons over het gehele depositietraject.

Figuur 33 geeft, voor een hypothetische situatie, aangepaste curven voor 0/1-data voor een beperkt aantal opnamen met verschillende deposities. De zwarte lijn geeft de curve voor een lineair logistisch model en de groene lijn die voor een kwadratisch model. Het kwadratische model geeft al een beter verband weer, maar het nadeel van het kwadratische model is de slechte extrapolatie buiten het waarnemingsgebied voor de depositie (stippellijn). De smoothing spline met DF=5 (blauw) geeft een 'wilde curve die teveel reageert op lokale verschillen in de dichtheid van enen en nullen. De spline met $\mathrm{DF}=2$ (rood) geeft een optimaal resultaat.

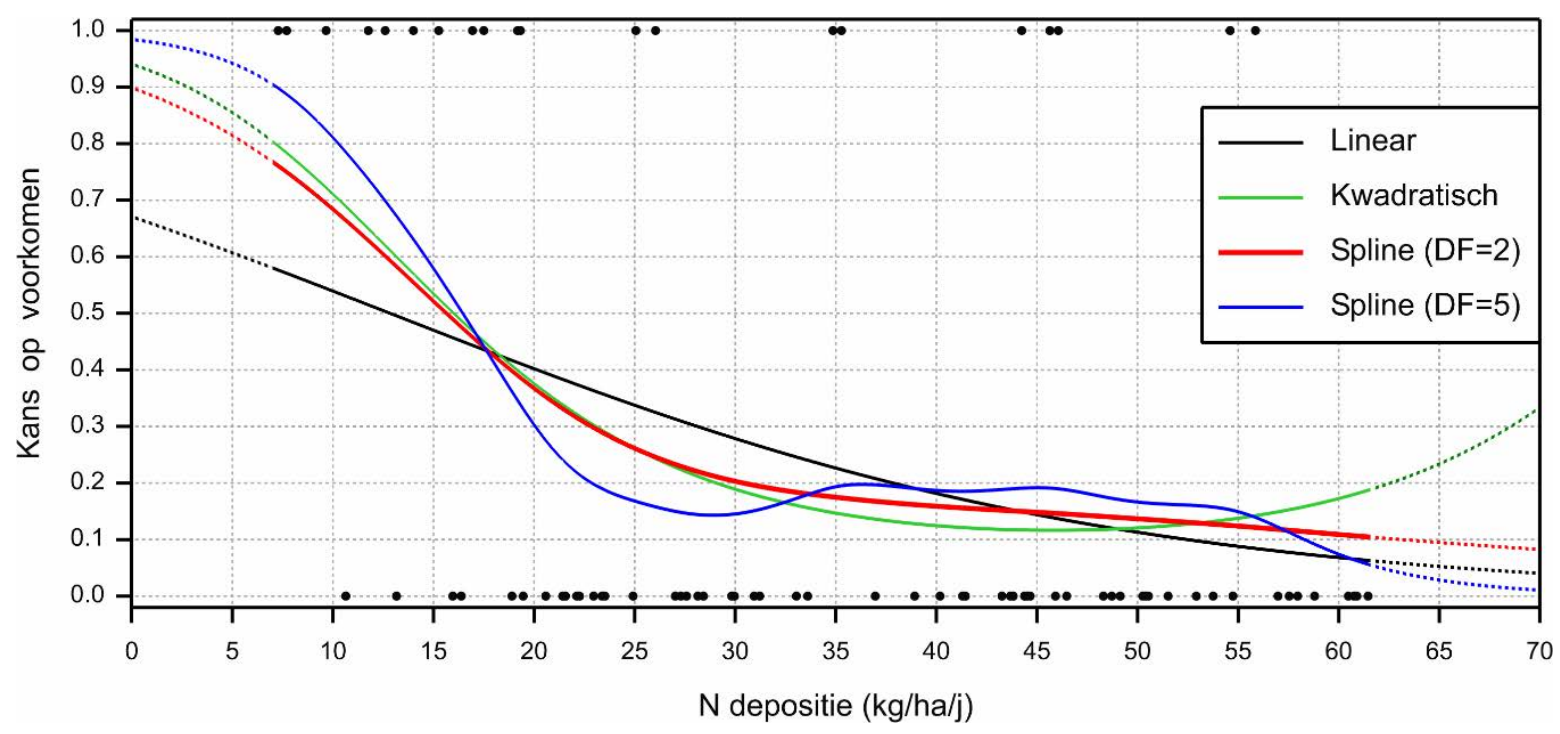

Figuur 33 Voorbeeld van een dataset (zwarte punten) met enen (aanwezigheid) en nullen (afwezigheid) van een soort in opnamen met verschillende stikstofdeposities. De lijnen geven aangepaste curven voor verschillende modellen waarbij extrapolatie beneden de laagste en boven de hoogste depositiewaarden wordt weergegeven door gestippelde lijnen. 
Om extrapolatie van responscurven naar zeer lage of zeer hoge depositiewaarden te voorkomen, zijn onder- en bovengrenzen voor de depositie vastgesteld waarbinnen de responscurven worden weergegeven. Daartoe is, op basis van de dataset per structuurtype/soortcombinatie, per habitattype, het $1 \%$ - en $99 \%$-percentiel van de depositie berekend voor de bij het habitattype behorende soorten. Voor habitattype $1310-\mathrm{A}^{4}$, met structuurtype zout, geeft dat bijvoorbeeld 5 percentielen voor de vijf bijbehorende soorten. De percentielen zijn grafisch weergegeven in Figuur 34. Op basis hiervan is per structuurtype enigszins arbitrair een onder- en een bovengrens bepaald. Deze zijn weergegeven door de verticale groene lijnen in Figuur 34. Ondergrenzen zijn vastgesteld met intervallen van een kwart $\mathrm{kmol} / \mathrm{ha} / \mathrm{j}$., bovengrenzen met intervallen van een halve $\mathrm{kmol} / \mathrm{ha} / \mathrm{j}$.

\footnotetext{
4 In dit deel van het rapport worden de gebruikelijke codes voor habitattypen vanwege de onderscheidbaarheid in de figuren wat anders geschreven: zonder $\mathrm{H}$ en met koppelteken in het geval van subtypen.
} 
$\mathrm{N}$ depositie Ruw $(\mathrm{kmol} / \mathrm{ha} / \mathrm{j})$

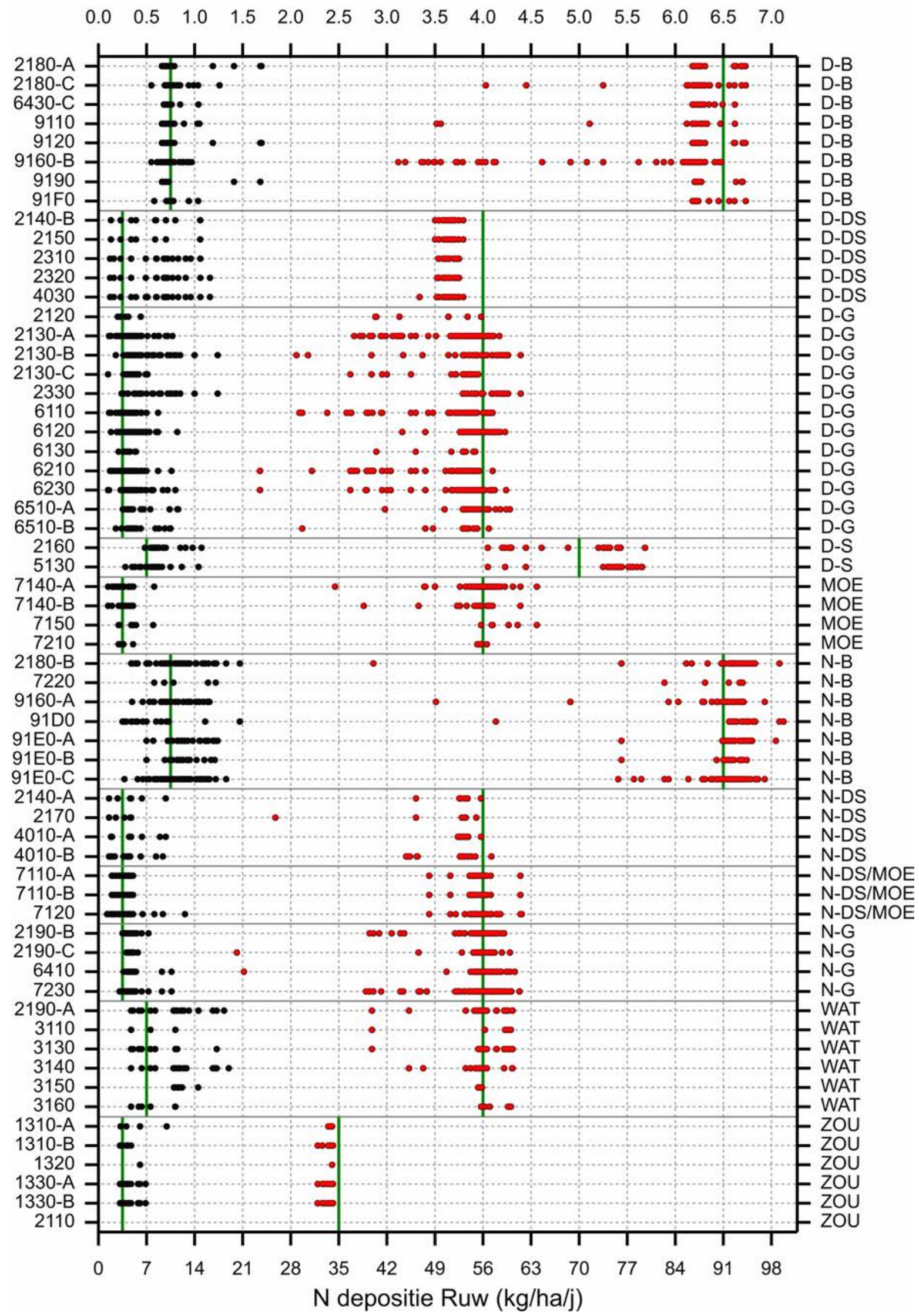

Figuur 34 Voor elk habitattype (linker $y$-as), gesorteerd naar bijbehorend structuurtype (rechter $y$-as), wordt het 1\%-percentiel (zwart) en het 99\%-percentiel (rood) van de waargenomen stikstofrange van de bijbehorende soorten gegeven (de tussenliggende opnamen worden dus niet weergegeven). De groene lijnen geven het interval aan waarbinnen de responscurven worden gegeven. 
Het programma dat de curven schat, is geschreven in Genstat (VSN International, 2020). Het programma is te vinden in Bijlage 10.

\section{B.2.1.10 Responscurven voor habitattypen}

Voor een habitattype kan een responscurve verkregen worden door responscurven van de kwalificerende soorten of te sommeren of te middelen. De gesommeerde curve kan geïnterpreteerd worden als het gemiddelde aantal verwachte kwalificerende soorten. Bij sommatie wegen algemene soorten, met een hogere kans op voorkomen, veel zwaarder dan zeldzame soorten, met een lagere kans op voorkomen. Bij hogere stikstofdeposities kan de som daarnaast gedomineerd worden door de toenemende kans op het voorkomen van kwalificerende verdringingssoorten. Figuur 35 geeft responscurven voor een fictief habitattype $X$ zijn gegeven voor zes fictieve kwalificerende soorten: twee algemene soorten, twee zeldzame soorten en twee kwalificerende verdringingssoorten. De gemiddelde kans over alle zes soorten wordt gedomineerd door de algemene en de kwalificerende verdringingssoorten. Na weglating van de verdringingssoorten wordt de gemiddelde kans gedomineerd door de algemene soorten. Middelen over alleen de zeldzame soorten resulteert in een sterk dalende curve.

Habitat $X$ bestaat uit 6 soorten met onderstaande response curves
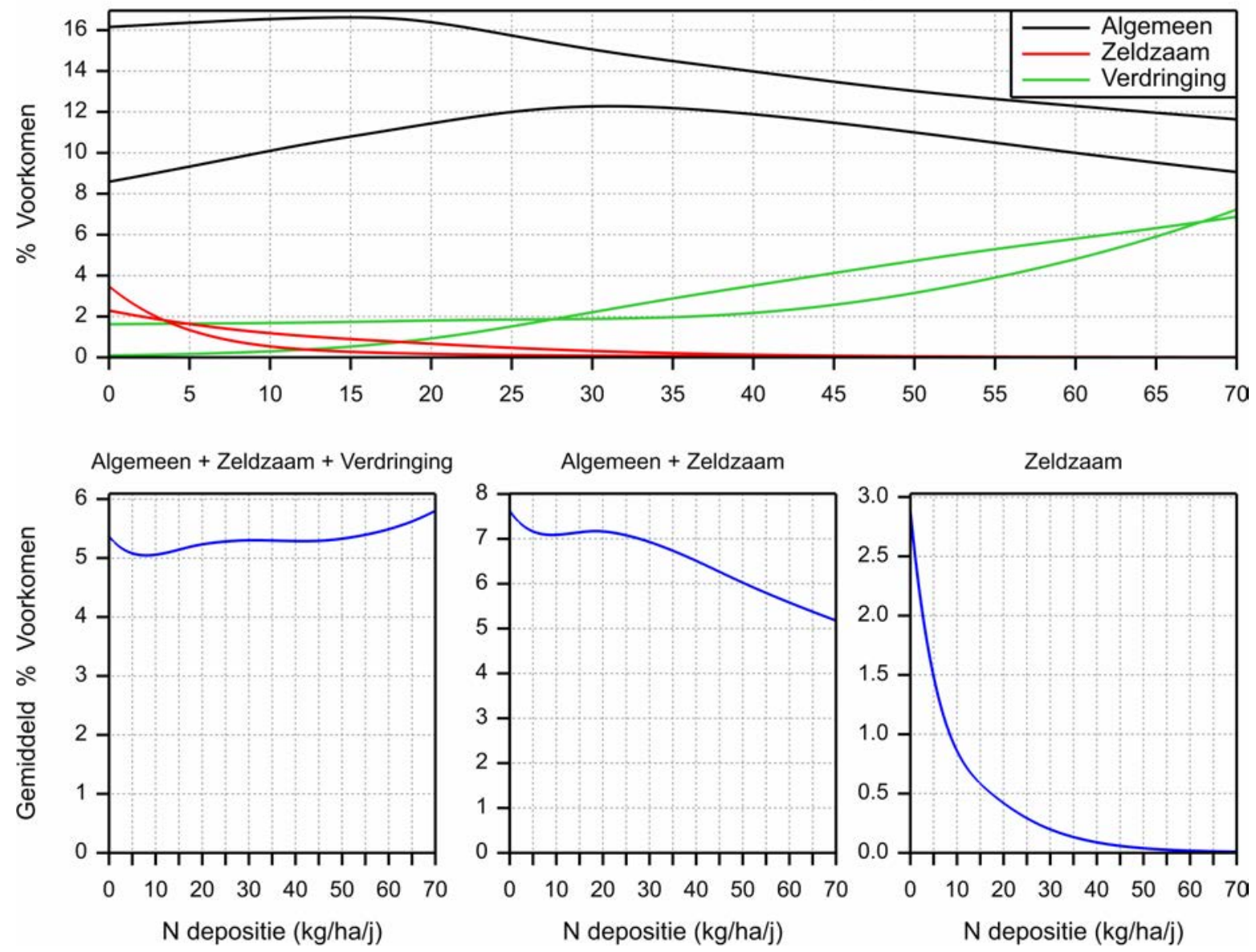

Figuur 35 Responscurven (bovenste grafiek) voor een fictief habitattype met twee algemene soorten, twee zeldzame soorten en twee kwalificerende verdringingssoorten. De onderste grafieken geven de gemiddelde responscurven voor verschillende selecties van soorten. 

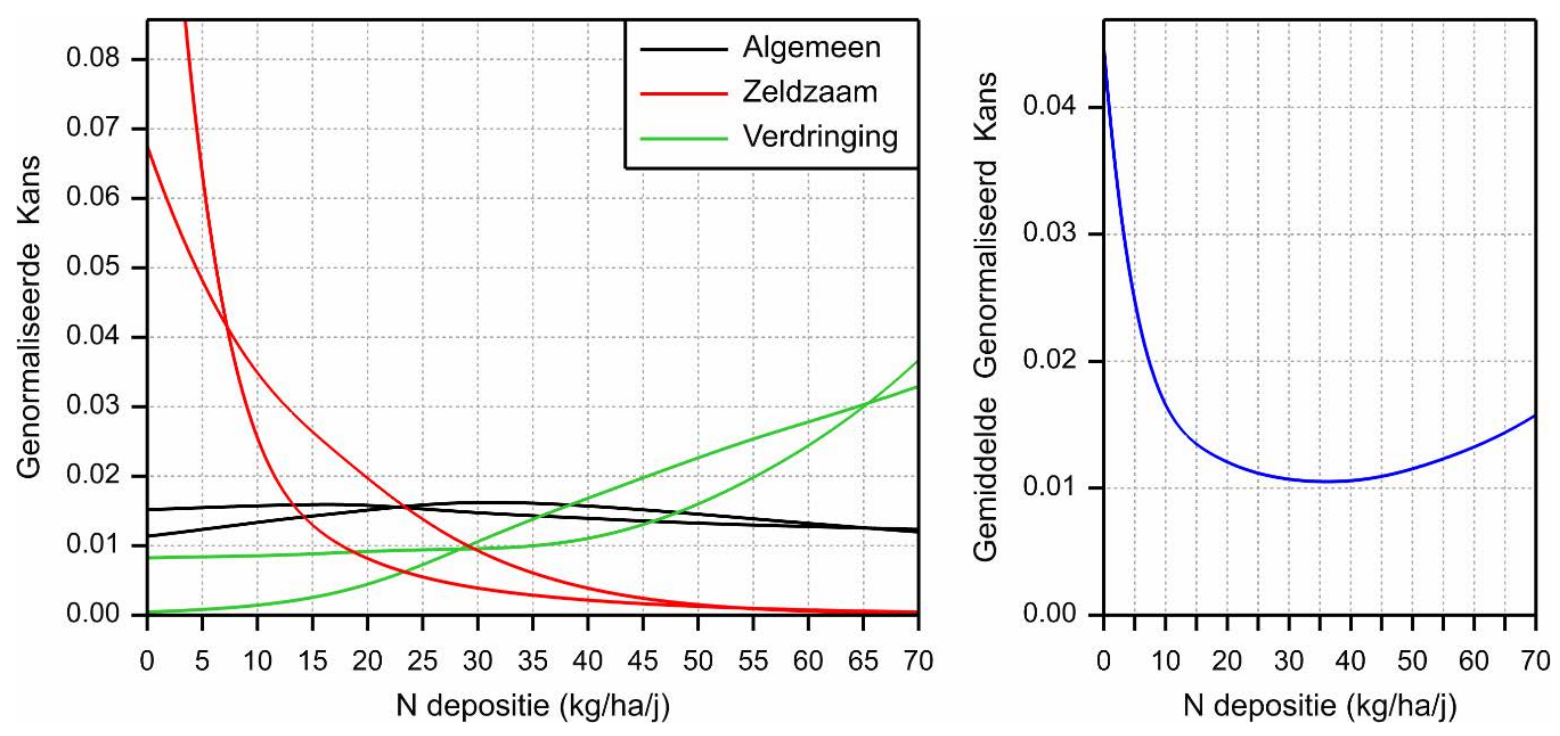

Figuur 36 Genormaliseerde responscurven met oppervlakte één onder elke curve voor een fictief habitattype met twee algemene soorten, twee zeldzame soorten en twee kwalificerende verdringingssoorten. De rechtergrafiek geeft het gemiddelde van de genormaliseerde curven voor het habitattype.

Een meer gelijksoortige weging van de responscurven van de soorten wordt verkregen door de responscurven te normaliseren. In dit project is gekozen voor een normalisering naar oppervlakte onder de curve, zodanig dat elke genormaliseerde responscurve een oppervlakte gelijk aan 1 heeft, zie Figuur 37. Het gemiddelde van de genormaliseerde responscurven reflecteert nu beter de sterke afname van de kans op voorkomen van de zeldzame soorten. In een meer subjectieve benadering zou elke soort een door experts vastgesteld gewicht kunnen krijgen waarbij zeldzame soorten een hoger gewicht kunnen krijgen. Dit is eerder toegepast in de 'Gelderland-methode' (Van Dobben et al., 2015).

De responscurven voor individuele soorten zijn aangepast aan data over een beperkte range van stikstofdeposities. Daarom wordt de normalisatie uitgevoerd op basis van de range zoals gegeven in Figuur 34.
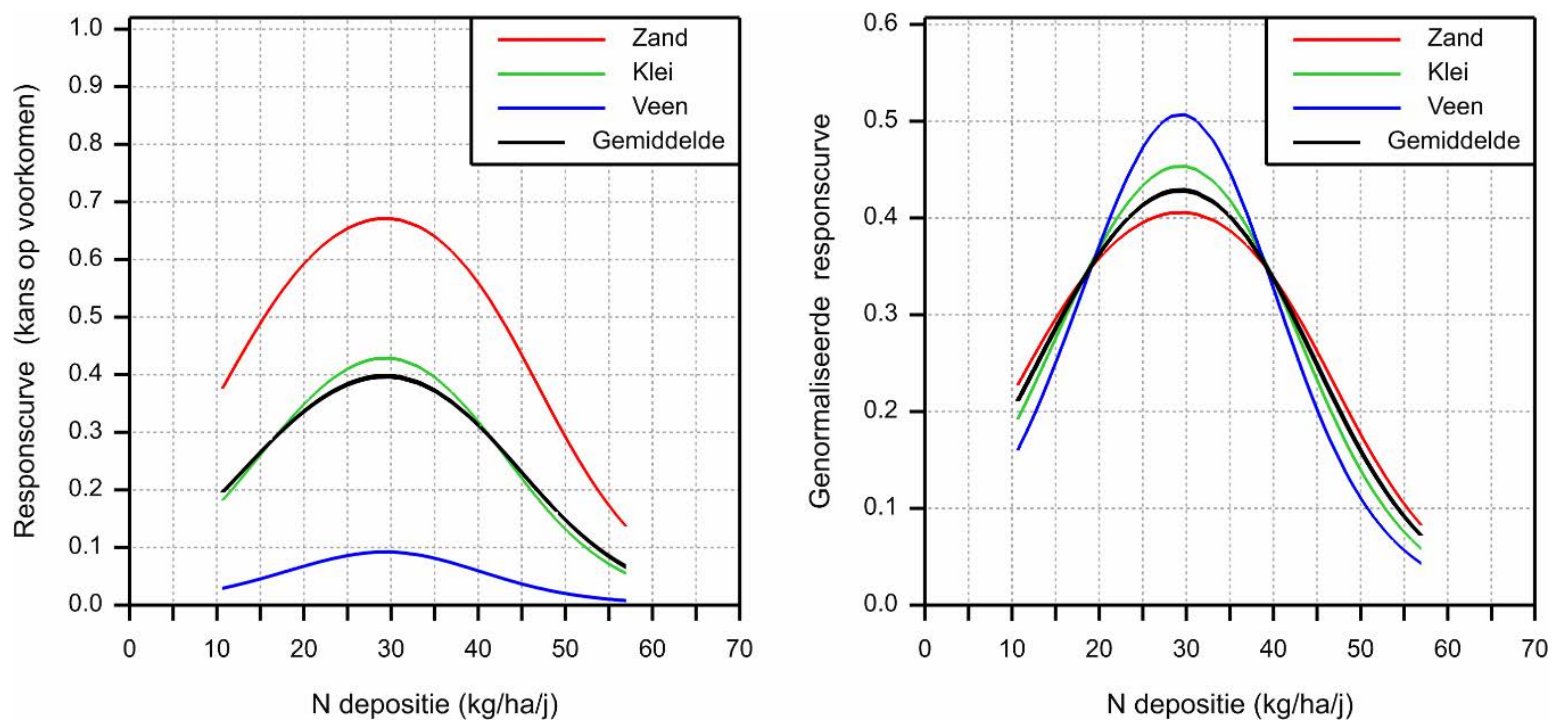

Figuur 37 Voorbeeld van geschatte responscurven voor drie bodemtypen, inclusief de over bodemtypen gemiddelde curve (links) voor een logistisch regressiemodel waarin gecorrigeerd wordt voor bodemtype. Rechts worden dezelfde curven gegeven na normalisatie tot oppervlakte 1. 
Door de normalisatie is de precieze wijze van middelen over bodemtypen en de precieze ingevulde waarden voor temperatuur en regenval minder van belang. Figuur $38 \mathrm{geeft}$ links een voorbeeld van de geschatte responscurven voor drie bodemtypen. Deze curven lopen parallel op de logit-schaal; op de kansschaal hebben ze dezelfde vorm met verschillende maximale kansen (linkerfiguur). $\mathrm{Na}$ normalisatie tot oppervlakte 1 (rechterfiguur) is er veel minder verschil tussen de curven.

\section{B.2.1.11 Beoordeling van responscurven voor habitattypen}

De responscurven voor de habitattypen zijn beoordeeld op plausibiliteit en ingedeeld in goed, matig en slecht. Alle in dit rapport behandelde habitattypen hebben een KDW en de kwaliteit wordt dus aangetast bij een toenemende stikstofdepositie. Een plausibele responscurve moet dus een vorm hebben die hierbij aansluit, met een daling van de curve vanaf de KDW of binnen de range van de empirische KDW. Dergelijke curven zijn als goed beoordeeld. Stijgende responscurven daarentegen komen niet overeen met de resultaten die ten grondslag liggen aan de vastgestelde KDW's; deze worden als slecht beoordeeld. De categorie matig is vooral gebruikt voor curven die mogelijk wel plausibel zijn, maar die een wat onverwachte respons laten zien, bijvoorbeeld een snelle of grootste daling al voordat de KDW wordt bereikt. Deze beoordeling is enigszins subjectief.

\section{B.2.1.12 Samenvatting van materiaal en methoden}

Een gedetailleerde onderbouwing van de gemaakte keuzes bij het bepalen van de responscurven voor habitattypen is gegeven Bijlage 8. Een korte stapsgewijze beschrijving van de methode is hieronder gegeven.

Kwalificerende plantensoorten voor alle 61 Nederlandse habitat(sub)typen met een KDW zijn gebaseerd op 'De Vegetatie van Nederland' (Schaminée et al., 1995). Daarbij zijn twee criteria gebruikt: (1) de presentie in Nederland en (2) de trouwgraad van de soort. Zogenaamde typische soorten, voor zover niet reeds op deze wijze geselecteerd, zijn toegevoegd (paragraaf B.2.1.1).

De 67 habitattypen zijn ingedeeld in 11 zogenaamde vegetatiestructuurtypen (paragraaf B.2.1.2). De vegetatieopnamen zijn, via het EUNIS-type, ook toegewezen aan deze 11 structuurtypen. Opnamen met een onbekend structuurtype zijn niet gebruikt (paragraaf B.2.1.4).

Waargenomen aan- en afwezigheid van soorten is gebaseerd op vegetatieopnamen in de EVA-database. Daarbij zijn alleen opnamen gebruikt vanaf 1950 in een selectiegebied, dat zich uitstrekt van Portugal tot Finland en van Ierland tot Oostenrijk. Opnamen boven de $500 \mathrm{~m}$ hoogte zijn niet geselecteerd (paragraaf B.2.1.3).

De stikstofdepositie van een opname is gebaseerd op het EMEP-model waarbij gemiddeld wordt over de depositie van het jaar van opname én de vier daaraan voorafgaande jaren. De stikstofdepositie is gecorrigeerd voor de ruwheidsfactor (op basis van EMEP-modellering) van de opname. Opnamen met een onbekende depositie of een niet-positieve depositie zijn niet gebruikt (paragraaf B.2.1.5).

Temperatuur en neerslag van de opnamen zijn geïnterpoleerd, waarbij gebruikgemaakt is van openbare databronnen (paragraaf B.2.1.6).

Het bodemtype van een opname is gebaseerd op de 'World Reference Base for Soil Resources'. Opnamen met bodemtypen die niet voorkomen in Nederland zijn niet gebruikt. Typen zijn samengevoegd in vijf klassen: zand, klei, jong, veen en water (paragraaf B.2.1.7).

Voor elke soort binnen een habitattype is een dataset met aan- en afwezigheid van de soort geconstrueerd door gebruik te maken van een geschat verspreidingsgebied dat gevormd wordt door cirkels van $25 \mathrm{~km}$ rond opnamen waar de soort voorkomt. Daarbij zijn alleen opnamen gebruikt die horen bij het structuurtype van het habitattype (paragraaf B.2.1.8).

De zo verkregen dataset voor een soort is gebruikt om een responscurve te schatten waarbij gecorrigeerd is voor temperatuur, neerslag en bodemtype. Er worden alleen curven geschat voor soorten die voorkomen in minimaal honderd vegetatieopnamen. Daarmee vallen zeer zeldzame soorten af. Om een curve voor Nederland te verkrijgen, alleen als functie van de stikstofdepositie, is 
gewogen gemiddeld over de bodemtypen en is de gemiddelde temperatuur en neerslag in de afgelopen tien jaar in Nederland ingevuld in de geschatte curve. Om extrapolatie van de responscurven te voorkomen, is voor elk habitattype een range van waargenomen stikstofdeposities gedefinieerd (paragraaf B.2.1.9).

Responscurven voor habitattypen zijn verkregen door genormaliseerde responscurven voor individuele soorten te middelen, waarbij het oppervlak onder de genormaliseerde responscurve van voorkomen van de soort tegen de stikstofdepositie voor alle soorten gelijk is (' 1 '). Door de normalisatie krijgen de soorten een gelijk gewicht bij middeling (paragraaf B.2.1.10).

De responscurven voor de habitattypen zijn beoordeeld op plausibiliteit in relatie tot de vastgestelde KDW (paragraaf B.2.1.11).

\section{B.2.2 Resultaten responscurven op basis van kwalificerende soorten}

\section{B.2.2.1 Aantal kwalificerende soorten na selectie van opnamen}

Door de selectie van vegetatieopnamen en het gekozen minimumaantal van honderd positieve waarnemingen per soort, blijven er voor een aantal habitattypen weinig kwalificerende soorten over (Tabel 5). Voor habitattype 2110 blijven er zelfs geen soorten over en voor dit type is dus geen responscurve geschat. Met één kwalificerende soort is de responscurve van het habitattype identiek aan die voor de kwalificerende soort. In totaal zijn er zes habitattypen, van de 61 stikstofgevoelige habitattypen, met minder dan vijf kwalificerende soorten. De responscurven voor deze typen kunnen onbetrouwbaar zijn. Immers, één afwijkende onbetrouwbare curve voor een soort kan al een onbetrouwbare curve geven voor het habitattype. Echter een responscurve op basis van minder dan vijf soorten hoeft niet onbetrouwbaar te zijn, mits de responscurven per soort goed geschat worden of de invloed van de foutief geschatte soort gering is. Het aantal waarnemingen per soort-typecombinatie is te vinden in Bijlage $8 \mathrm{C}$.

Tabel 5 Aantallen kwalificerende soorten per habitattype en het aantal soorten waarvoor een responscurve beschikbaar is. Geel gemarkeerde habitat(sub)typen hebben minder dan vijf soorten met een responscurve.

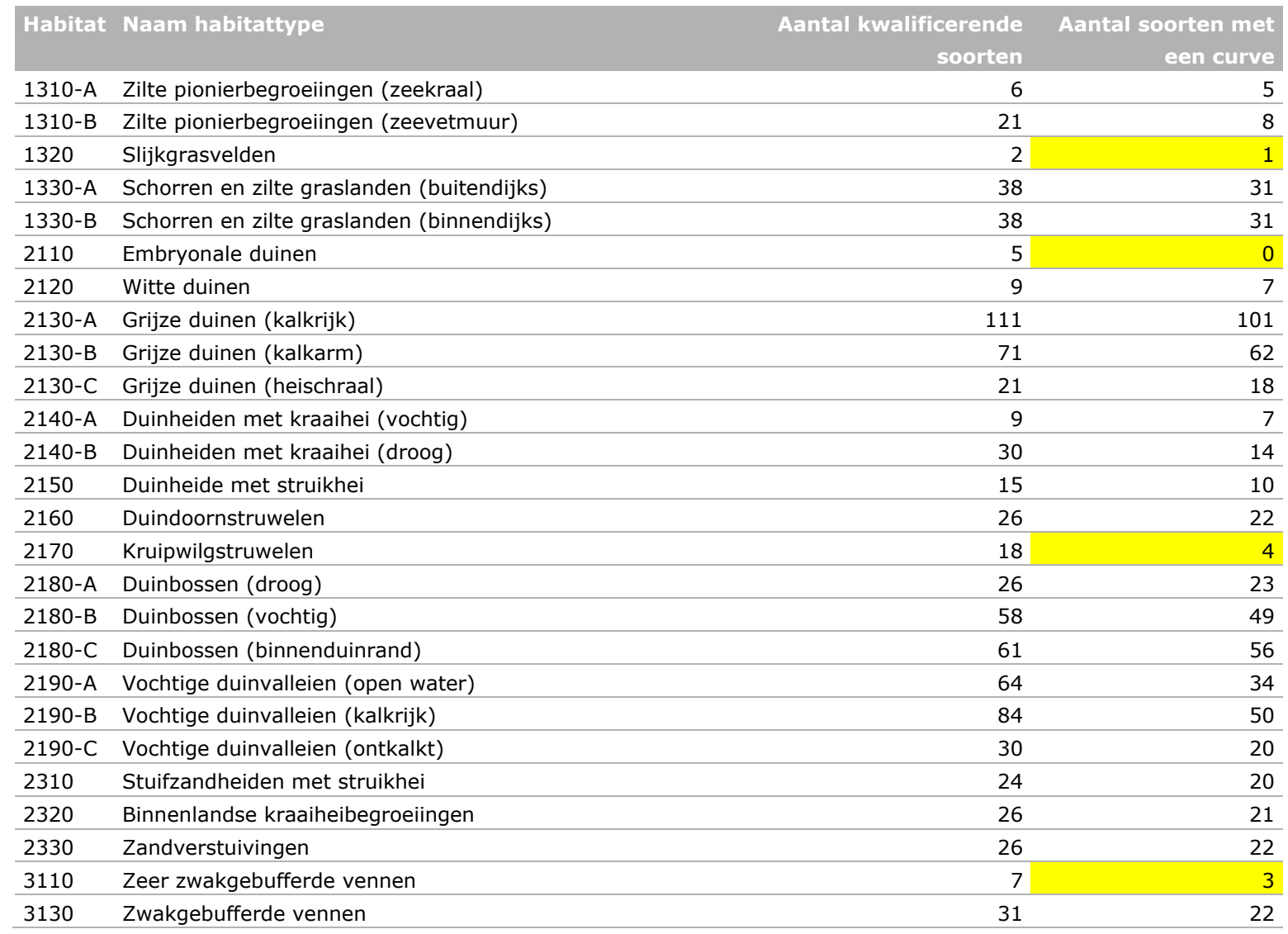




\begin{tabular}{|c|c|c|c|}
\hline Habitat & Naam habitattype & $\begin{array}{r}\text { Aantal kwalificerende } \\
\text { soorten }\end{array}$ & $\begin{array}{r}\text { Aantal soorten met } \\
\text { een curve }\end{array}$ \\
\hline 3140 & Kranswierwateren & 22 & 18 \\
\hline 3150 & Meren met krabbenscheer en fonteinkruiden & 11 & 10 \\
\hline 3160 & Zure vennen & 26 & 4 \\
\hline 4010-A & Vochtige heiden (hogere zandgronden) & 13 & 13 \\
\hline 4010-B & Vochtige heiden (laagveengebied) & 20 & 20 \\
\hline 4030 & Droge heiden & 30 & 25 \\
\hline 5130 & Jeneverbesstruwelen & 74 & 29 \\
\hline 6110 & Pionierbegroeiingen op rotsbodem & 60 & 57 \\
\hline 6120 & Stroomdalgraslanden & 86 & 82 \\
\hline 6130 & Zinkweiden & 13 & 10 \\
\hline 6210 & Kalkgraslanden & 71 & 68 \\
\hline 6230 & Heischrale graslanden & 75 & 69 \\
\hline 6410 & Blauwgraslanden & 39 & 37 \\
\hline $6430-\mathrm{C}$ & Ruigten en zomen (droge bosranden) & 22 & 16 \\
\hline 6510-A & Glanshaver- en vossenstaarthooilanden (glanshaver) & 37 & 36 \\
\hline 6510-B & Glanshaver- en vossenstaarthooilanden (grote vossenstaart) & 35 & 35 \\
\hline 7110-A & Actieve hoogvenen (hoogveenlandschap) & 21 & 20 \\
\hline $7110-B$ & Actieve hoogvenen (heideveentjes) & 22 & 21 \\
\hline 7120 & Herstellende hoogvenen & 56 & 49 \\
\hline $7140-A$ & Overgangs- en trilvenen (trilvenen) & 54 & 46 \\
\hline 7140-B & Overgangs- en trilvenen (veenmosrietlanden) & 22 & 19 \\
\hline 7150 & Pioniervegetaties met snavelbiezen & 12 & 6 \\
\hline 7210 & Galigaanmoerassen & 3 & 3 \\
\hline 7220 & Kalktufbronnen & 8 & 5 \\
\hline 7230 & Kalkmoerassen & 148 & 120 \\
\hline 9110 & Veldbies-beukenbossen & 32 & 27 \\
\hline 9120 & Beuken-eikenbossen met hulst & 23 & 21 \\
\hline 9160-A & Eiken-haagbeukenbossen (hogere zandgronden) & 41 & 31 \\
\hline 9160-B & Eiken-haagbeukenbossen (heuvelland) & 98 & 90 \\
\hline 9190 & Oude eikenbossen & 9 & 8 \\
\hline 91D0 & Hoogveenbossen & 26 & 18 \\
\hline 91E0-A & Vochtige alluviale bossen (zachthoutooibossen) & 38 & 26 \\
\hline 91E0-B & Vochtige alluviale bossen (essen-iepenbossen) & 21 & 16 \\
\hline 91E0-C & Vochtige alluviale bossen (beekbegeleidende bossen) & 79 & 72 \\
\hline $91 \mathrm{~F} 0$ & Droge hardhoutooibossen & 7 & 7 \\
\hline
\end{tabular}

\section{B.2.2.2 Beschrijvende tabellen en grafieken}

Het aantal opnamen per structuurtype is gegeven in Tabel 6. Er zijn in totaal 77.027 opnamen (16\%) met een ontbrekend structuurtype, waarvan 18.270 opnamen veroorzaakt worden door een ontbrekend EUNIS-type en de doorvertaling naar structuurtype. Opnamen zonder structuurtype worden niet gebruikt voor het afleiden van responscurven. Het aantal geselecteerde vegetatieopnamen is dus 404.730 ( $=48.1757-77.027)$.

Tabel 6 Aantal opnamen geclassificeerd naar structurtype.

\begin{tabular}{lrrr} 
Structuurtype & Afkorting & Aantal & Percentage \\
$?$ & - & 77027 & 16.0 \\
\hline Droog dwergstruweel & D-DS & 7233 & 1.5 \\
\hline Droog grasland & D-G & 213861 & 44.4 \\
\hline Droog loofbos & D-B & 40126 & 8.3 \\
\hline Droog struweel & D-S & 5857 & 1.2 \\
\hline Moeras & MOE & 45255 & 9.4 \\
\hline Nat dwergstruweel & N-DS & 28173 & 5.8 \\
\hline Nat grasland & N-G & 33399 & 6.9 \\
\hline Nat loofbos & N-B & 13150 & 2.7 \\
\hline Water & WAT & 12365 & 2.6 \\
\hline Zout & ZOU & 5311 & 1.1 \\
\hline Totaal & - & $\mathbf{4 8 1 7 5 7}$ & $\mathbf{1 0 0 . 0}$
\end{tabular}


Het aantal geselecteerde opnamen geclassificeerd naar structuurtype en bodem is gegeven in Tabel 7 en naar land en grondsoort in Tabel 8. Voor Droog grasland zijn de meeste opnamen beschikbaar en voor zout de minste. De meeste droge graslandenkomen voor op klei en zand. De meeste opnamen liggen op kleibodems in Nederland en Denemarken. Het aantal beschikbare opnamen per bodem en structuurtype geeft enig inzicht in de onzekerheid van de uiteindelijke schattingen voor de soorten.

Tabel 7 Totaal aantal geselecteerde opnamen geclassificeerd naar structuurtype en grondsoort.

\begin{tabular}{|c|c|c|c|c|c|c|c|}
\hline Structuurtype & Afkorting & Jong & Klei & Veen & Water & Zand & Totaal \\
\hline Droog dwergstruweel & D-DS & 1838 & 1012 & 444 & 26 & 3913 & 7233 \\
\hline Droog grasland & $D-G$ & 51098 & 79819 & 15206 & 1517 & 66221 & 213861 \\
\hline Droog struweel & $D-S$ & 2604 & 2171 & 164 & 47 & 871 & 5857 \\
\hline Moeras & MOE & 9866 & 19458 & 4750 & 466 & 10715 & 45255 \\
\hline Nat grasland & $\mathrm{N}-\mathrm{G}$ & 6643 & 14077 & 2220 & 399 & 10060 & 33399 \\
\hline Nat loofbos & $\mathrm{N}-\mathrm{B}$ & 3356 & 4641 & 1061 & 177 & 3915 & 13150 \\
\hline Water & WAT & 1913 & 5177 & 2994 & 277 & 2004 & 12365 \\
\hline Zout & ZOU & 1060 & 3789 & 85 & 7 & 370 & 5311 \\
\hline
\end{tabular}

Tabel 8 Totaal aantal geselecteerde opnamen geclassificeerd naar land en grondsoort. De landen zijn gesorteerd naar het totaalaantal opnamen per land.

\begin{tabular}{|c|c|c|c|c|c|c|}
\hline Land & Jong & Klei & Veen & Water & Zand & Totaal \\
\hline NLD & 8996 & 46375 & 21713 & 1902 & 34033 & 113019 \\
\hline DNK & 11248 & 30678 & 1548 & - & 57314 & 100788 \\
\hline DEU & 19477 & 19128 & 3258 & 429 & 14364 & 56656 \\
\hline GBR & 19495 & 21880 & 1042 & - & 567 & 42984 \\
\hline BEL & 1588 & 2340 & 1 & - & 3086 & 7015 \\
\hline AUT & 685 & 3051 & 61 & - & 675 & 4472 \\
\hline ESP & 3248 & 760 & 1 & - & 2 & 4011 \\
\hline SWE & 1751 & - & 34 & - & 2011 & 3796 \\
\hline LUX & 93 & 109 & - & - & - & 202 \\
\hline PRT & 14 & 6 & - & - & 6 & 26 \\
\hline LIE & - & 26 & - & - & - & 26 \\
\hline Totaal & 100278 & 148303 & 30603 & 3159 & 122387 & 404730 \\
\hline
\end{tabular}

Een onderverdeling van het aantal opnamen per land en structuurtype is gegeven in Tabel 9 en de bijbehorende percentages per land in Tabel 10. Van de landen met veel opnamen zijn er in Frankrijk (FRA) relatief veel opnamen met een ontbrekend structuurtype. Van de landen met relatief weinig opnamen zijn er vooral in Zweden (SWE) en Finland (FIN) relatief veel opnamen met een ontbrekend structuurtype. Het structuurtype 'droog grasland' D-G komt in de meeste landen veruit het vaakst voor. Figuur 39 geeft een grafische voorstelling van de verdeling van de stikstofdepositie per structuurtype. Daarbij zijn zowel de voor ruwheid gecorrigeerde als de ongecorrigeerde depositie gegeven. Daaruit blijkt nogmaals dat de correctie voor ruwheid voor droog en nat loofbos én voor droog struweel een hogere depositie geeft. 
Tabel 9 Aantal geselecteerde opnamen geclassificeerd naar land en structuurtype.

\begin{tabular}{|c|c|c|c|c|c|c|c|c|c|c|c|}
\hline Land & D-DS & D-G & D-B & D-S & MOE & N-DS & N-G & $\mathrm{N}-\mathrm{B}$ & WAT & ZOU & Totaal \\
\hline NLD & 3803 & 54164 & 8975 & 1582 & 15889 & 6482 & 6961 & 5244 & 8236 & 1683 & 113019 \\
\hline DNK & 5 & 63480 & 520 & - & 12020 & 12171 & 11414 & - & 134 & 1044 & 100788 \\
\hline DEU & 545 & 37014 & 3365 & 389 & 5237 & 2974 & 4014 & 1476 & 795 & 847 & 56656 \\
\hline GBR & 512 & 31535 & 815 & 281 & 2861 & 925 & 5377 & 292 & 250 & 136 & 42984 \\
\hline BEL & 129 & 1542 & 2859 & 153 & 775 & 200 & 321 & 909 & 100 & 27 & 7015 \\
\hline AUT & 16 & 2337 & 760 & 46 & 381 & 112 & 257 & 527 & 11 & 25 & 4472 \\
\hline ESP & 126 & 1476 & 416 & 436 & 535 & 264 & 202 & 150 & 155 & 251 & 4011 \\
\hline SWE & 121 & 1556 & 716 & 81 & 215 & 779 & 75 & 245 & 3 & 5 & 3796 \\
\hline LUX & 1 & 45 & 147 & 2 & 3 & 1 & 1 & 2 & - & - & 202 \\
\hline PRT & - & 7 & 2 & - & 13 & 1 & 1 & - & 2 & - & 26 \\
\hline LIE & - & 16 & 1 & 5 & - & 1 & - & 3 & - & - & 26 \\
\hline Totaal & 7233 & 213861 & 40126 & 5857 & 45255 & 28173 & 33399 & 13150 & 12365 & 5311 & 404730 \\
\hline
\end{tabular}

Tabel 10 Percentage geselecteerde opnamen per structurtype voor elk land.

\begin{tabular}{|c|c|c|c|c|c|c|c|c|c|c|c|}
\hline Land & D-DS & D-G & D-B & D-S & MOE & N-DS & N-G & $\mathrm{N}-\mathrm{B}$ & WAT & ZOU & $\%$ Totaal \\
\hline NLD & 3.4 & 47.9 & 7.9 & 1.4 & 14.1 & 5.7 & 6.2 & 4.6 & 7.3 & 1.5 & 100 \\
\hline DNK & 0.0 & 63.0 & 0.5 & - & 11.9 & 12.1 & 11.3 & - & 0.1 & 1.0 & 100 \\
\hline DEU & 1.0 & 65.3 & 5.9 & 0.7 & 9.2 & 5.2 & 7.1 & 2.6 & 1.4 & 1.5 & 100 \\
\hline GBR & 1.2 & 73.4 & 1.9 & 0.7 & 6.7 & 2.2 & 12.5 & 0.7 & 0.6 & 0.3 & 100 \\
\hline BEL & 1.8 & 22.0 & 40.8 & 2.2 & 11.0 & 2.9 & 4.6 & 13.0 & 1.4 & 0.4 & 100 \\
\hline AUT & 0.4 & 52.3 & 17.0 & 1.0 & 8.5 & 2.5 & 5.7 & 11.8 & 0.2 & 0.6 & 100 \\
\hline ESP & 3.1 & 36.8 & 10.4 & 10.9 & 13.3 & 6.6 & 5.0 & 3.7 & 3.9 & 6.3 & 100 \\
\hline SWE & 3.2 & 41.0 & 18.9 & 2.1 & 5.7 & 20.5 & 2.0 & 6.5 & 0.1 & 0.1 & 100 \\
\hline LUX & 0.5 & 22.3 & 72.8 & 1.0 & 1.5 & 0.5 & 0.5 & 1.0 & - & - & 100 \\
\hline PRT & - & 26.9 & 7.7 & - & 50.0 & 3.8 & 3.8 & - & 7.7 & - & 100 \\
\hline LIE & - & 61.5 & 3.8 & 19.2 & - & 3.8 & - & 11.5 & - & - & 100 \\
\hline Totaal & 1.8 & 52.8 & 9.9 & 1.4 & 11.2 & 7.0 & 8.3 & 3.2 & 3.1 & 1.3 & 100 \\
\hline
\end{tabular}



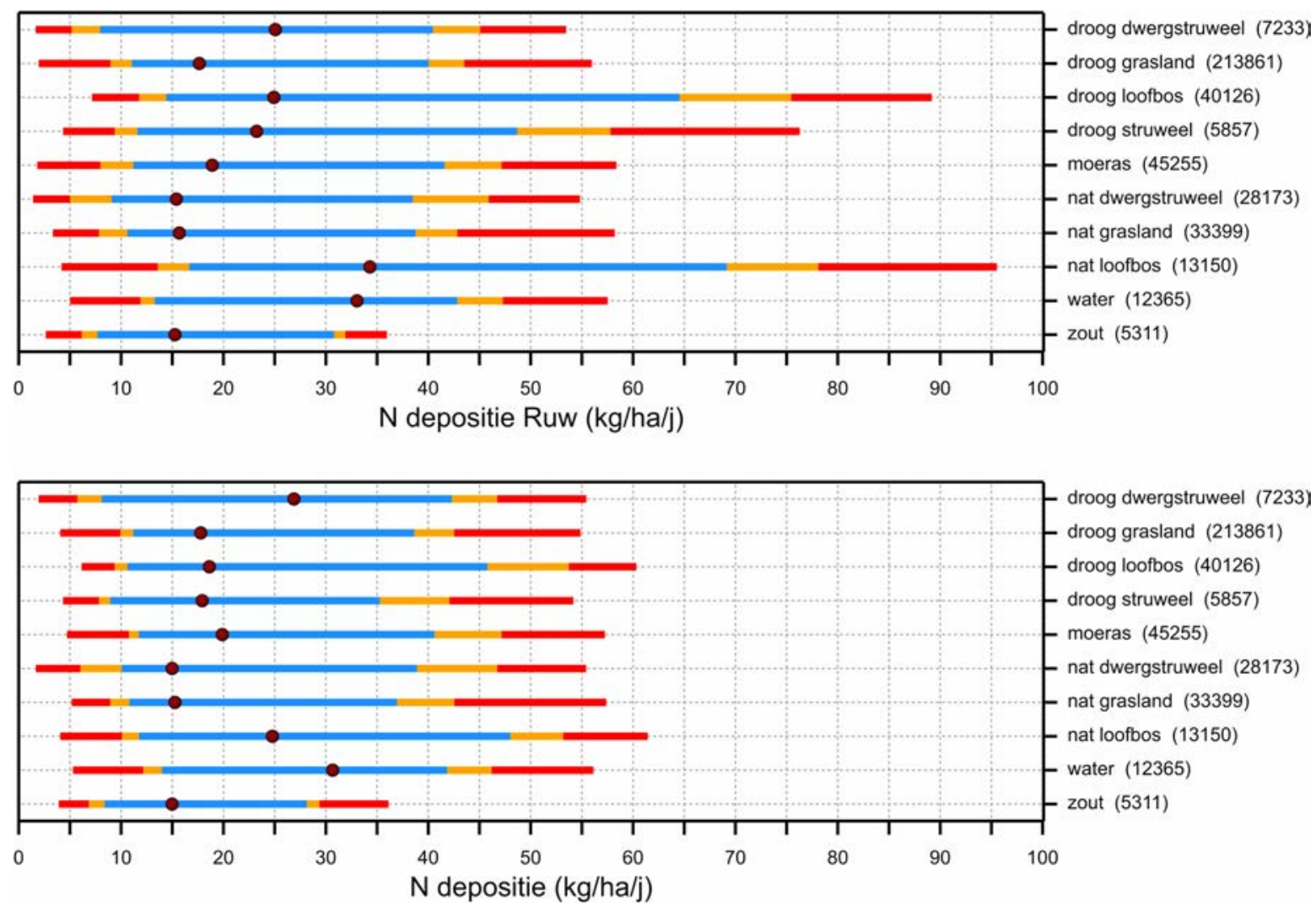

Figuur 38 Verdeling van de voor ruwheid gecorrigeerde (boven) en ongecorrigeerde (onder) stikstofdepositie per vegetatiestructuurtype voor de geselecteerde opnamen. De blauwe lijn representeert de centrale $80 \%$-range, de oranje lijn verlengt dit tot de $90 \%$-range en de rode lijn tot de $99 \%$-range. De zwarte punten geven de mediaan aan en het aantal vegetatieopnamen is gegeven tussen haakjes.

Een grafische voorstelling van de verdeling van stikstofdepositie, temperatuur en regenval per land is gegeven in Figuur 40. Nederland heeft de hoogste depositie, gevolgd door Duitsland en België. De Scandinavische landen hebben de laagste depositie. De temperatuurverdeling in de meest noordelijke landen (SWE, NOR, FIN) en de meest zuidelijke landen (ESP, PRT) wijkt nogal af van de verdeling in Nederland, wat invloed kan hebben op de groei, maar ook op de mineralisatie van organisch materiaal en dus het vrijkomen van voedingsstoffen, waaronder nitraat. Regenval in sommige Ierse en met name Noorse opnamen is zeer hoog, wat tot een hogere afspoeling en uitspoeling van nutriënten kan leiden. De verdeling van de depositie per grondtype in Nederland is gegeven in Figuur 41. 

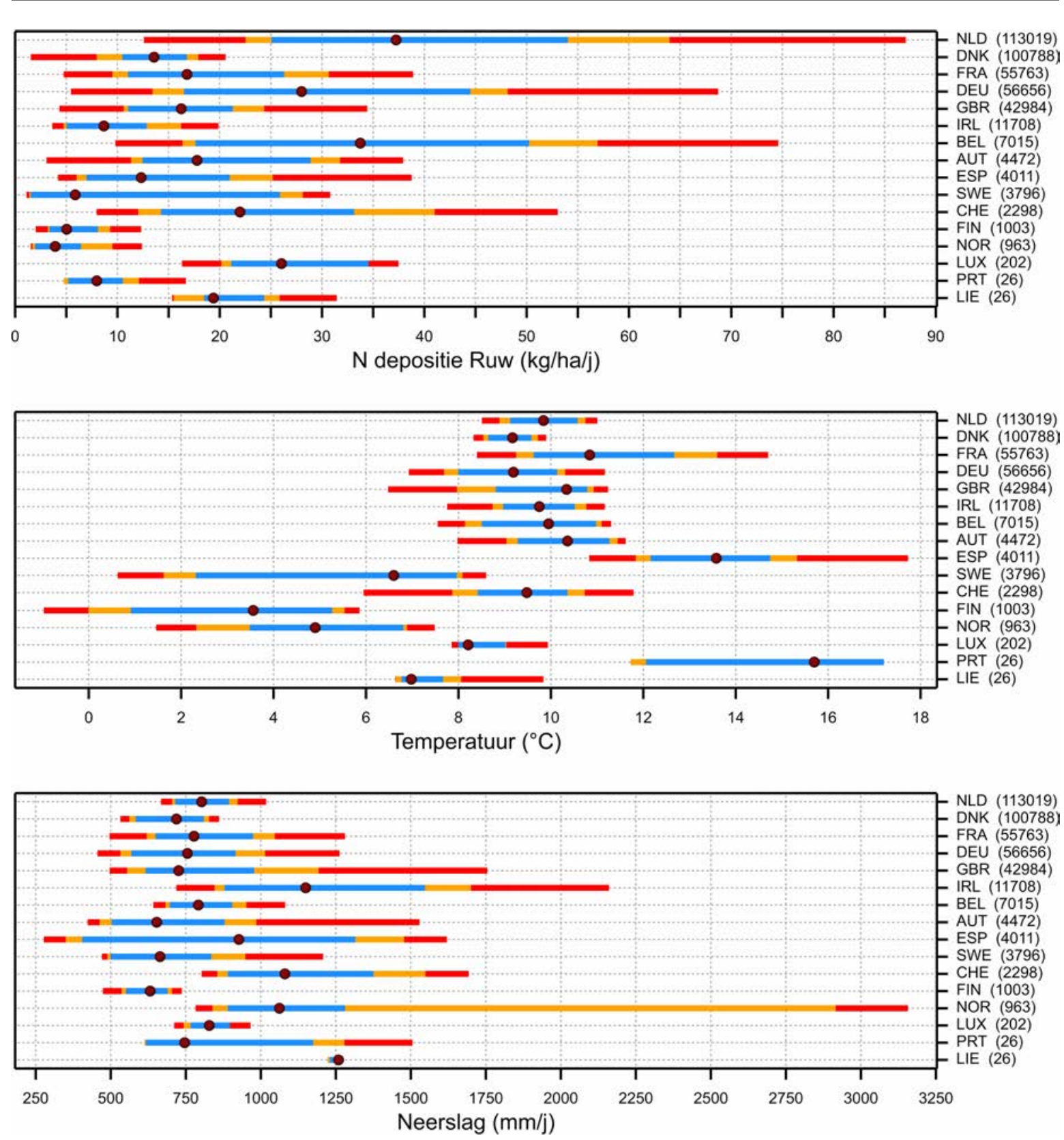

Figuur 39 Verdeling van $\mathrm{N}$-depositie, temperatuur en regenval per land voor de geselecteerde opnamen. De blauwe lijn representeert de centrale $80 \%$-range, de oranje lijn verlengt dit tot de $90 \%$ range en de rode lijn tot de $99 \%$-range. De zwarte punten geven de mediaan aan en het aantal opnamen is gegeven tussen haakjes.

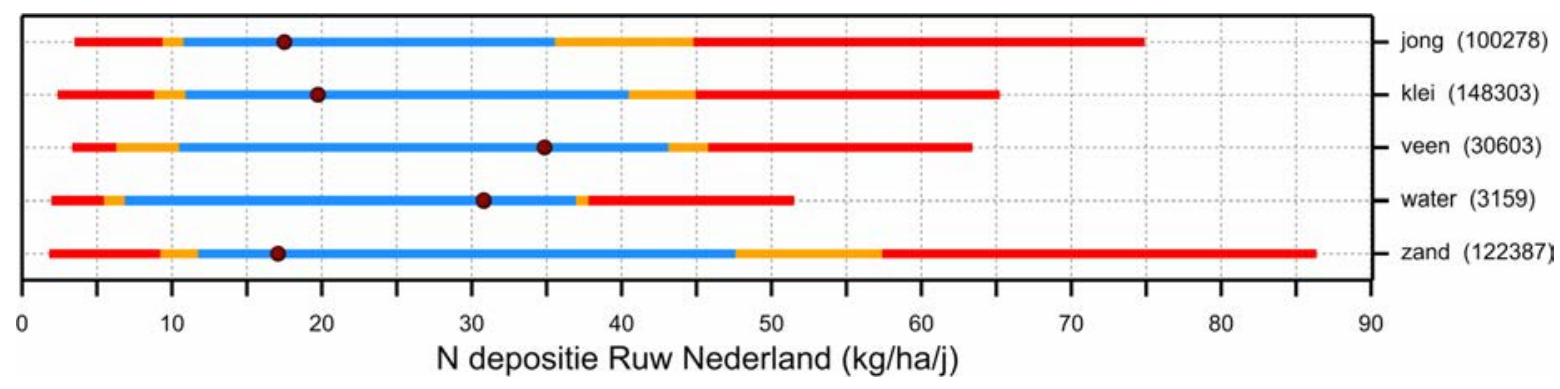

Figur 40 Verdeling van N-depositie per bodemtype in Nederland voor de geselecteerde opnamen. De blauwe lijn representeert de centrale $80 \%$-range, de oranje lijn verlengt dit tot de $90 \%$-range en de rode lijn tot de $99 \%$-range. De zwarte punten geven de mediaan aan en het aantal opnamen is gegeven tussen haakjes. 


\section{B.2.2.3 Responscurven voor kwalificerende soorten van habitattypen}

In Bijlage 9 wordt per habitattype allereerst de responscurve gegeven voor het habitattype zelf, gevolgd door de genormaliseerde responscurven van de bij het habitattype behorende soorten. In deze bijlage worden, zowel voor het habitattype als voor de individuele soorten, de volgende responsies gegeven:

- Een responscurve waarbij geen rekening is gehouden met de covariabelen (rood, $\mathrm{X}$ );

- Een responscurve waarbij gecorrigeerd is voor temperatuur, neerslag en hun interactie (groen, W);

- Een responscurve waarbij gecorrigeerd is voor bodem (blauw, B);

- Een responscurve waarbij zowel gecorrigeerd is voor temperatuur, neerslag en hun interactie alsmede voor bodem (zwart, WB).

In het algemeen valt op dat het verschil tussen de responscurven op basis van geen of verschillende covariabelen vaak gering is. Als er al verschillen zijn, is dat vaak tussen de curven zonder covariabelen en bodemtype enerzijds (rood $X$ en blauw $B$ ) en de curven voor weer (temperatuur, neerslag en hun interactie) en alle covariabelen anderzijds (groen W en zwart WB). Het effect van het meenemen van de covariabelen is dus relatief gering, waarbij het effect voornamelijk bepaald wordt door de weergegevens.

De responscurve waarbij alle covariabelen worden meegenomen, is uiteindelijk geselecteerd. Deze wordt hieronder steeds besproken.

De resulterende responscurven, na correctie voor temperatuur, neerslag en bodem, zijn per habitat(sub)type gegeven in Figuur 42 tot en met Figuur 52. In deze figuren zijn ook de individuele responscurven van de kwalificerende soorten in grijstint gegeven, zodat duidelijk wordt wat de verschillen zijn per soort en hoe dat doorwerkt in de responscurve voor het hele (sub)type.

In de figuren is met een stip in de rechterbovenhoek aangegeven hoe de plausibiliteit is beoordeeld: goed (groen), matig (geel) of slecht (rood). Daarop wordt in de volgende paragraaf ingegaan. Het valt op dat de meeste responscurven voor de habitattypen dalen vanaf het begin van de waargenomen $\mathrm{N}$ depositie. Voorbeelden van uitzonderingen zijn:

- Zilte pioniersbegroeiingen (1310-A, Figuur 42); dit wordt veroorzaakt door één kwalificerende soort met een sterk oplopende curve.

- Glanshaver- en vossenstaarthooilanden (Glanshaver, 6510-A, Figuur 49) met eerst een plateau en daarna pas een dalende curve.

- Slijkgrasvelden (1320, Figuur 42 met slechts één soort), Vochtige heiden (hogere zandgronden, 4010-A, Figuur 47) en Ruigten en Zomen (droge bosranden, 6430-C, Figuur 49) met een min of meer horizontale responscurve. De typen 4010-A en 6430-C hebben zowel soorten die afnemen als soorten die toenemen als gevolg van stikstofdepositie. Dit betekent niet dat er geen effect is van stikstofdepositie, het effect kan gemaskeerd worden door soorten die toenemen. Ook kan het duiden op niet-plausibele responscurven voor de onderliggende soorten.

- Overgangs- en trilvenen (veenmosrietlanden, 7140-B, Figuur 50) en Droge hardhoutooibossen (91FO, Figuur 52) met een vaak lichte optimumcurve, met eerst een stijging van de genormeerde kans op voorkomen en daarna een daling.

Daarnaast is er een aantal habitattypen dat in de daling een soort plateau vertoont, dat wil zeggen een range aan stikstofdeposities waar de responscurve niet of nauwelijks daalt. Op basis van de figuren is een schatting gemaakt van de range waarover de depositie daalt. Dit is afgerond op $5 \mathrm{~kg} / \mathrm{ha} / \mathrm{j}$. De range voor de daling loopt van $15 \mathrm{~kg} / \mathrm{ha} / \mathrm{j}$. tot de maximumwaarde, die voor bostypen $85 \mathrm{~kg} / \mathrm{ha} / \mathrm{j}$. is. Voor veel typen lijkt de minimale waarde voor de kwaliteit nog niet te zijn bereikt aan het einde van de range waarvoor de curve is geschat. 
$1310-A(Z O U)$

Zilte pionierbegroeiingen (zeekraal)
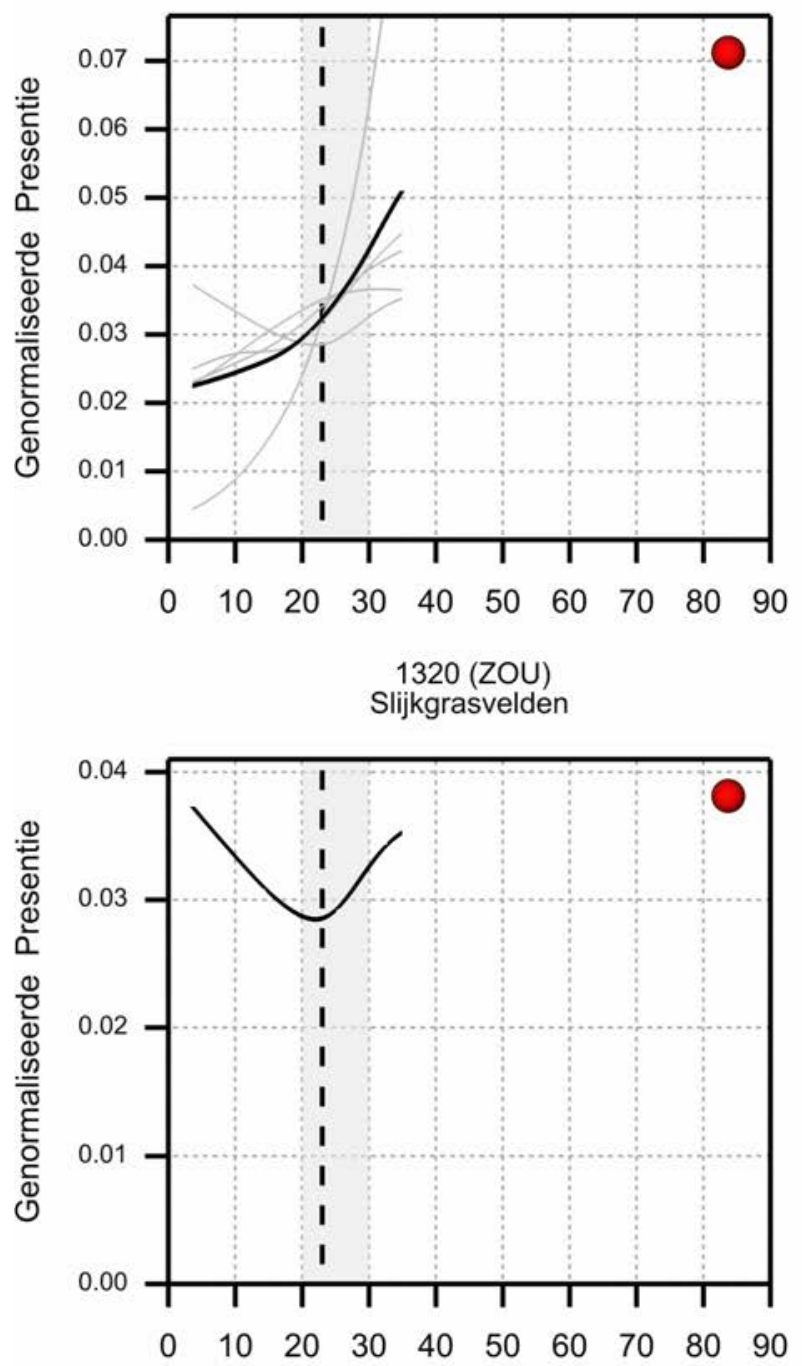

1330-B (ZOU)

Schorren en zilte graslanden (binnendijks)

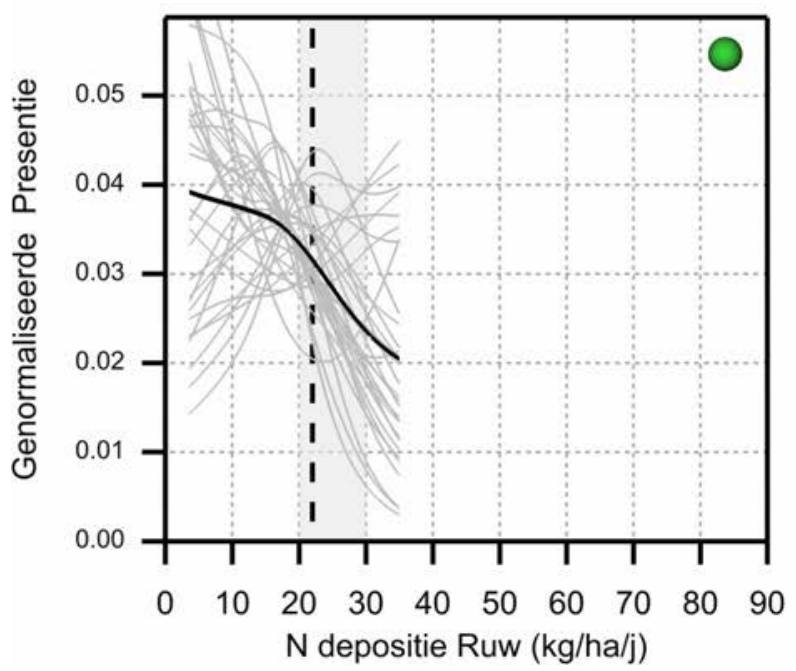

1310-B (ZOU)

Zilte pionierbegroeiingen (zeevetmuur)

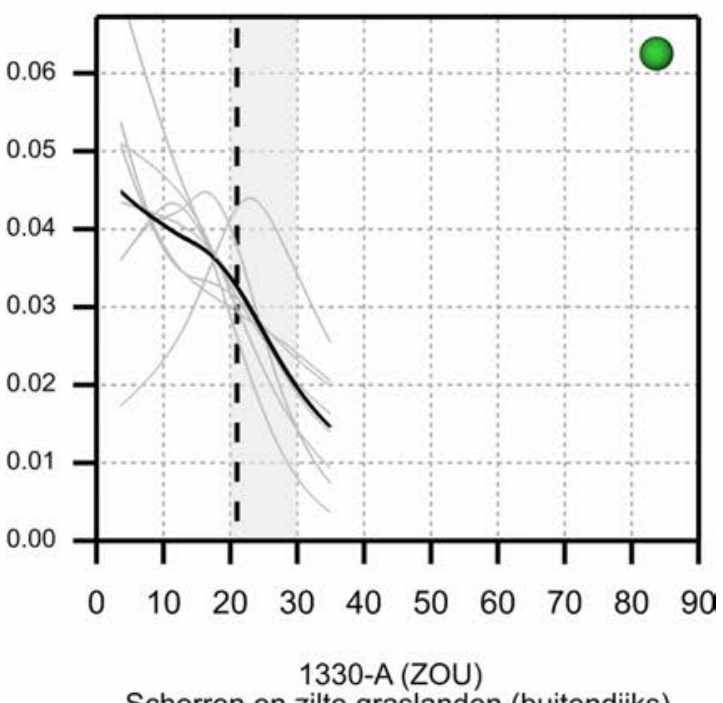

Schorren en zilte graslanden (buitendijks)
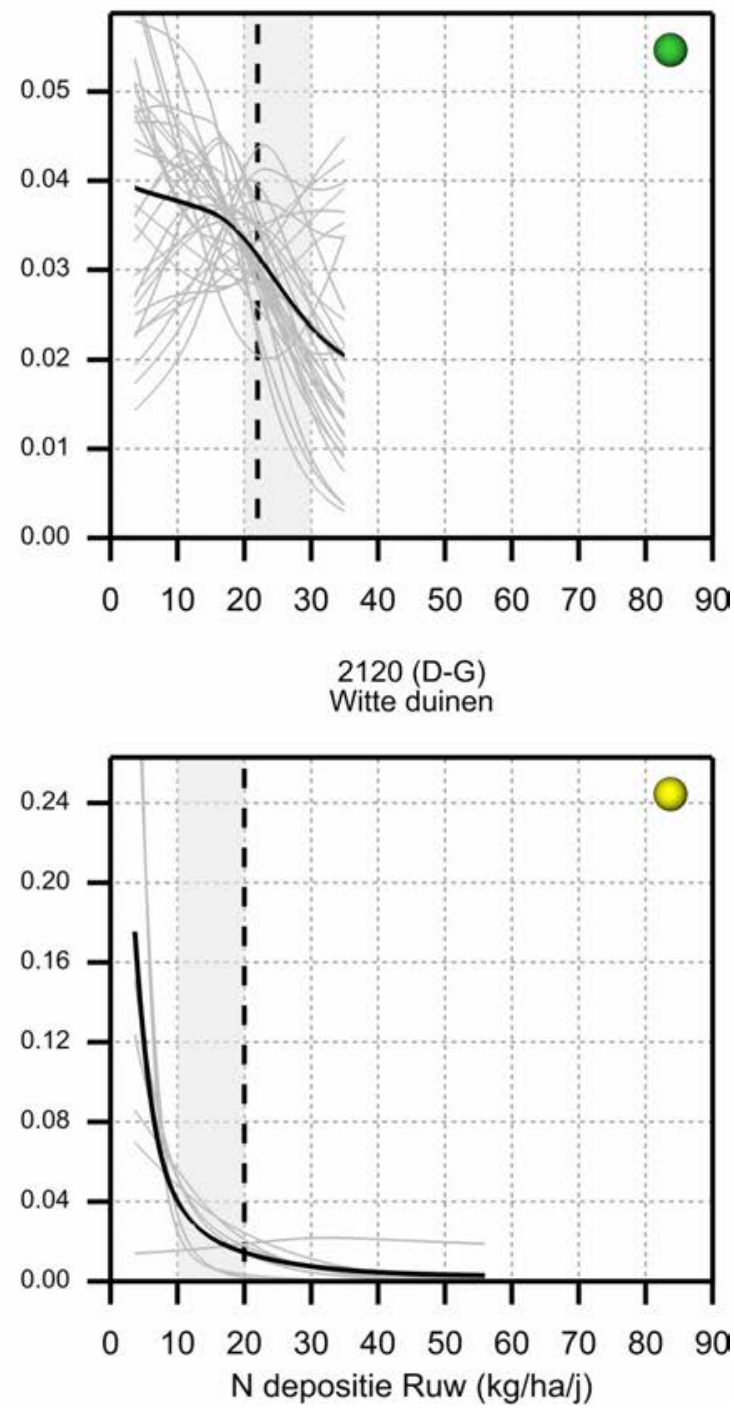

Figuur 41 Responscurven van habitattypen voor stikstofdepositie. De lichtgrijze lijnen geven de afzonderlijke curven van de kwalificerende soorten. De verticale gestippelde lijn geeft de KDW (Van Dobben et al., 2012), het grijze vak de range in empirische kritische depositiewaarden (Bobbink \& Hettelingh, 2011). In de kop wordt tussen haken het structuurtype gegeven (Tabel 2). De kleurcodering geeft de expertbeoordeling van de curve als in Tabel 11 (groen=goed, geel=matig, rood=slecht). 
$2130-A(D-G)$

Grijze duinen (kalkrijk)

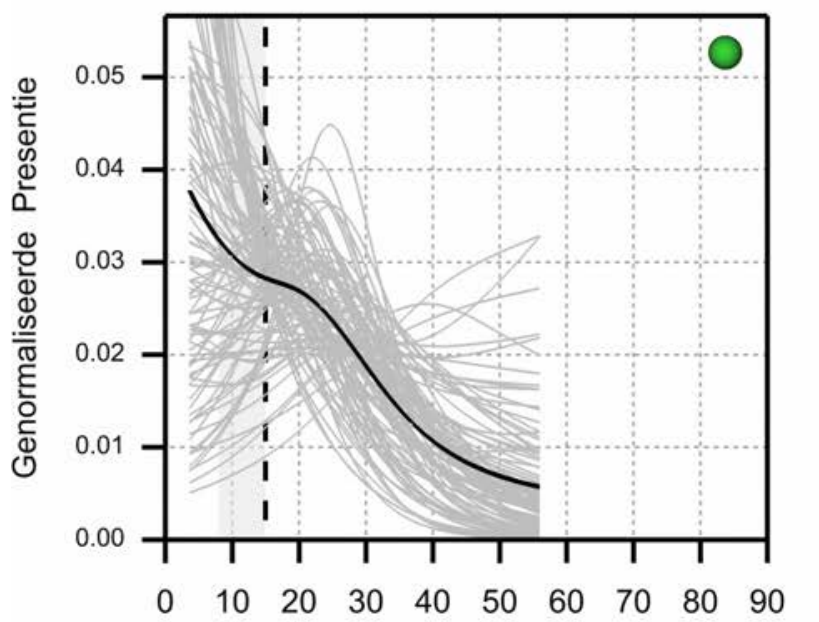

2130-C (D-G)

Grijze duinen (heischraal)

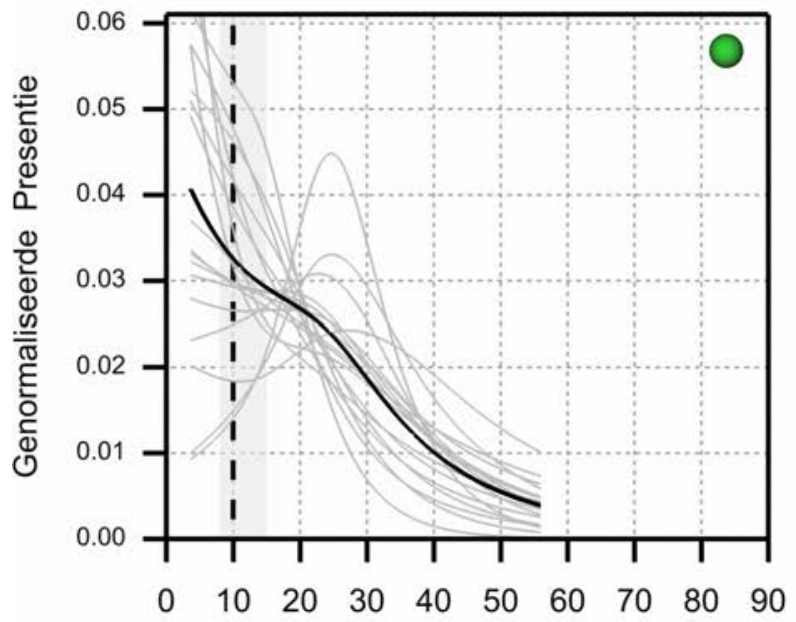

2140-B (D-DS)

Duinheiden met kraaihei (droog)

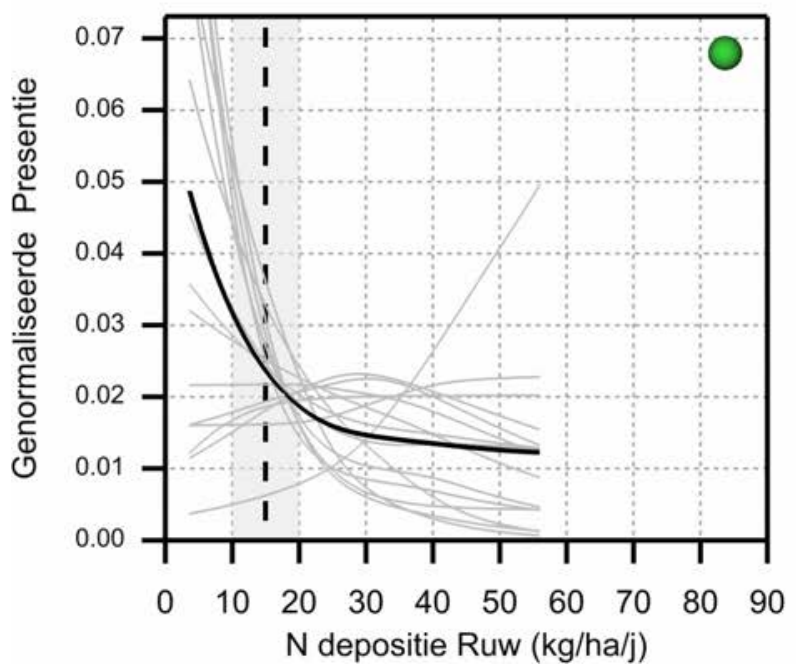

2130-B (D-G)

Grijze duinen (kalkarm)
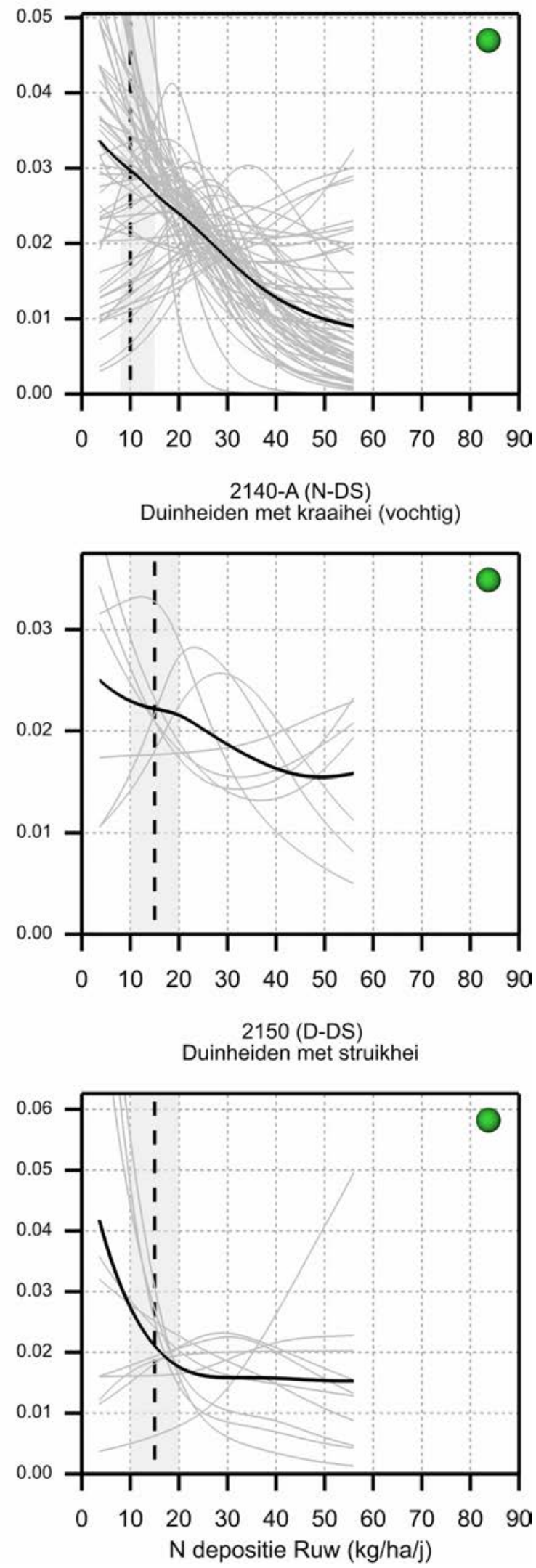

Figuur 42 Responscurven van habitattypen voor stikstofdepositie. De lichtgrijze lijnen geven de afzonderlijke curven van de kwalificerende soorten. De verticale gestippelde lijn geeft de KDW (Van Dobben et al., 2012), het grijze vak de empirische kritische depositiewaarde (Bobbink \& Hettelingh, 2011). In de kop wordt tussen haken het structuurtype gegeven (Tabel 2). De kleurcodering geeft de expertbeoordeling van de curve als in Tabel 11 (groen=goed, geel=matig, rood $=$ slecht). 
2160 (D-S)

Duindoornstruwelen

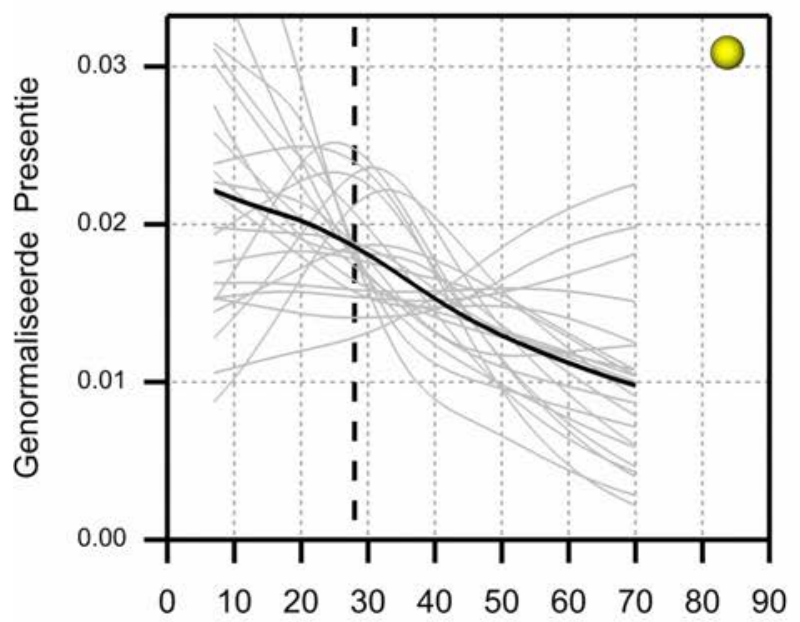

2180-A (D-B)

Duinbossen (droog)

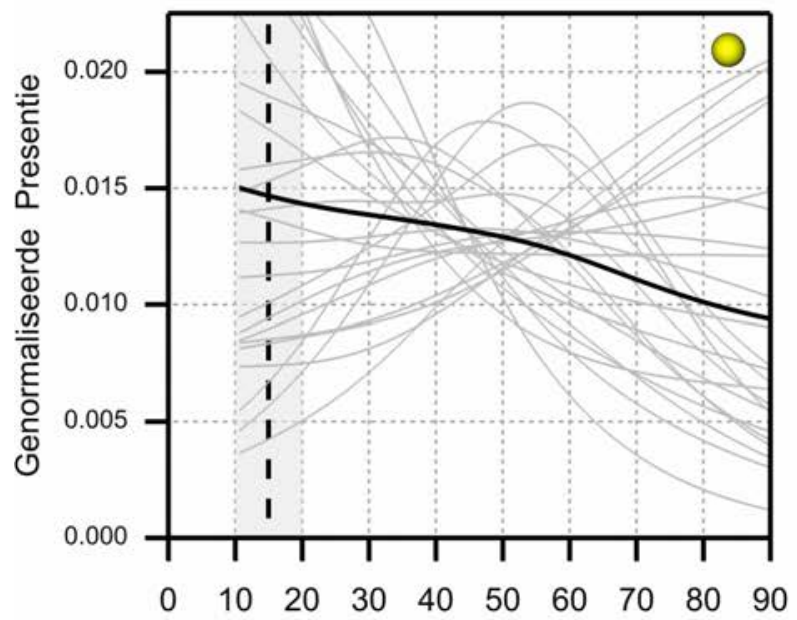

2180-C (D-B)

Duinbossen (binnenduinrand)

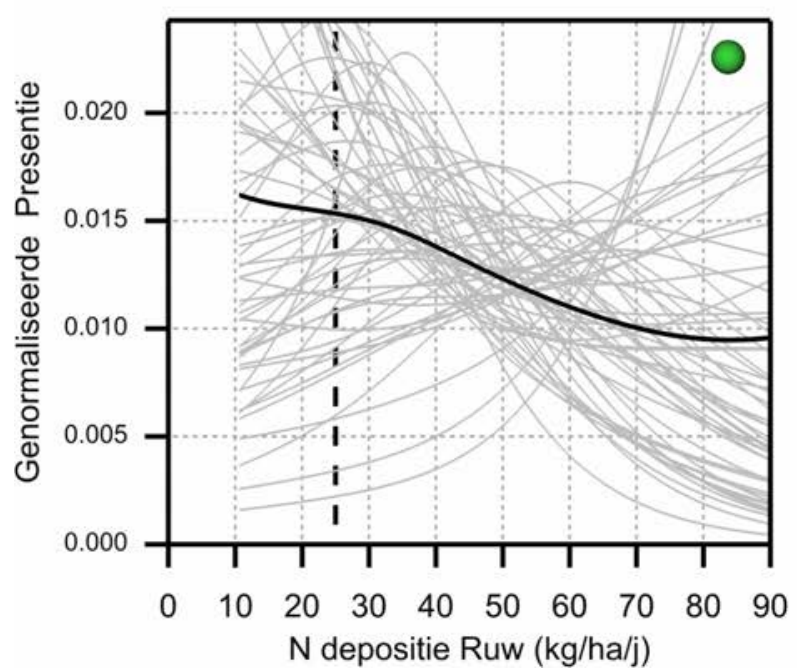

2170 (N-DS)

Kruipwilgstruwelen
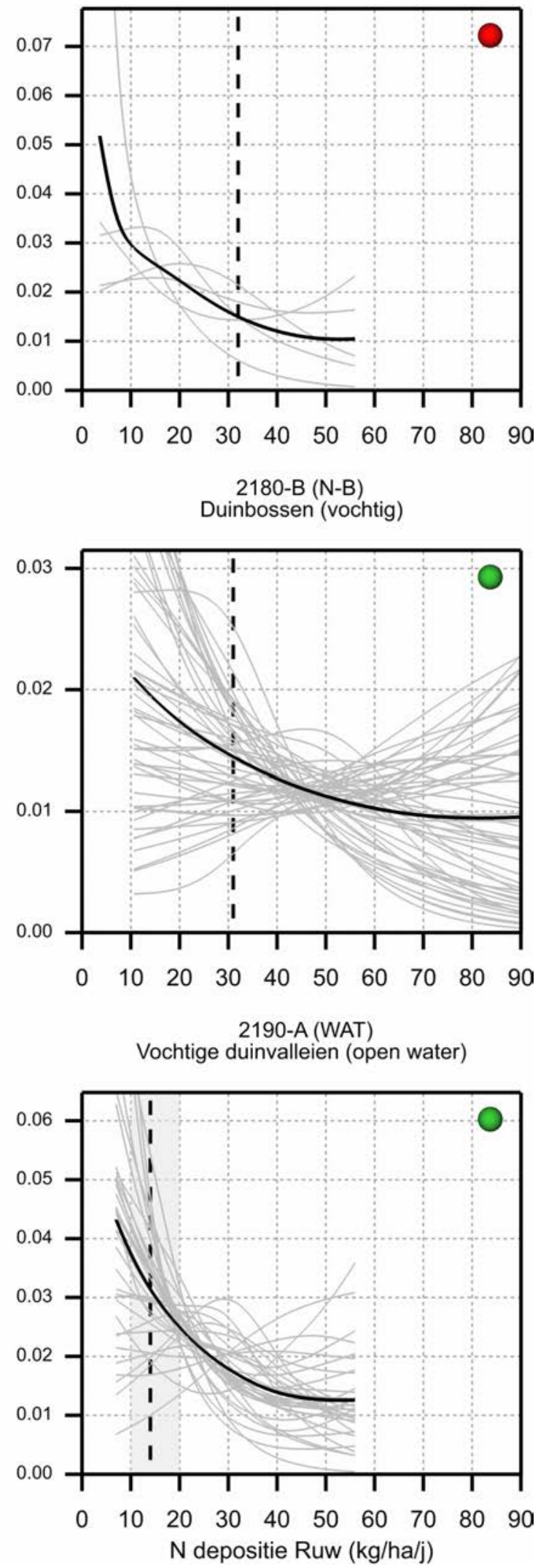

Figuur 43 Responscurven van habitattypen voor stikstofdepositie. De lichtgrijze lijnen geven de afzonderlijke curven van de kwalificerende soorten. De verticale gestippelde lijn geeft de KDW (Van Dobben et al., 2012), het grijze vak de empirische kritische depositiewaarde (Bobbink \& Hettelingh, 2011). In de kop wordt tussen haken het structuurtype gegeven (Tabel 2). De kleurcodering geeft de expertbeoordeling van de curve als in Tabel 11 (groen=goed, geel=matig, rood $=$ slecht). 
2190-B (N-G)

Vochtige duinvalleien (kalkrijk)
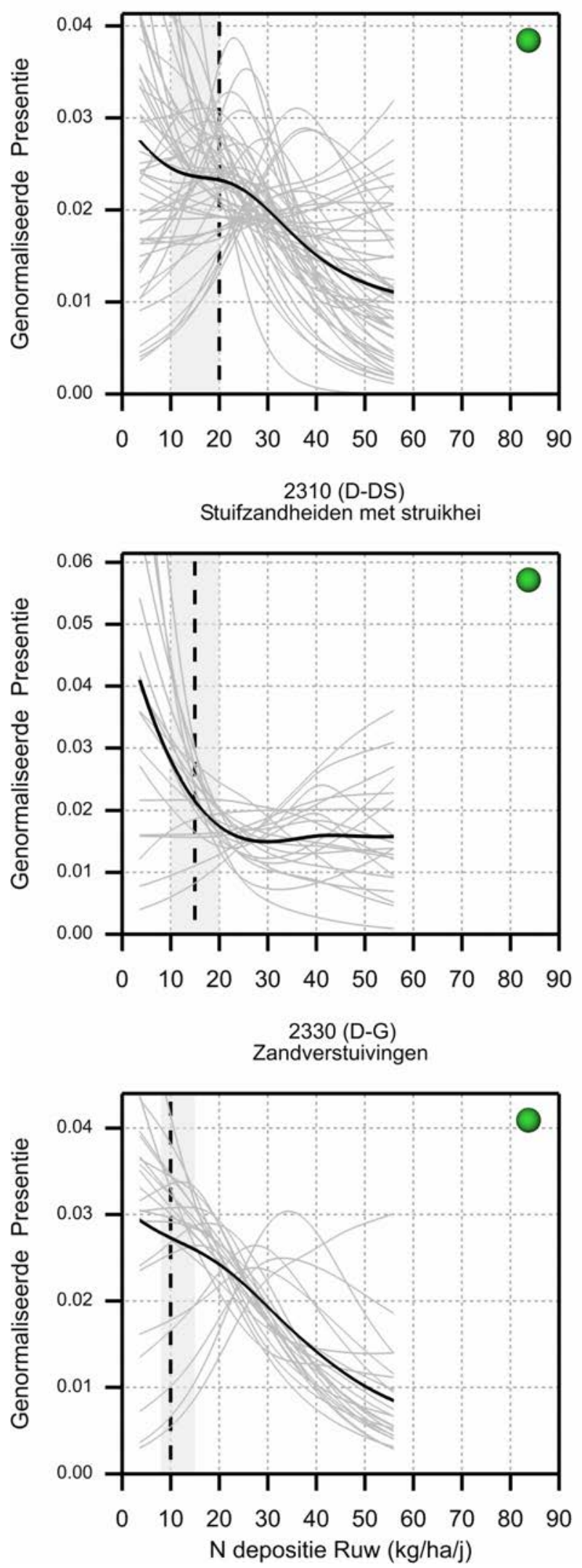

2190-C (N-G)

Vochtige duinvalleien (ontkalkt)
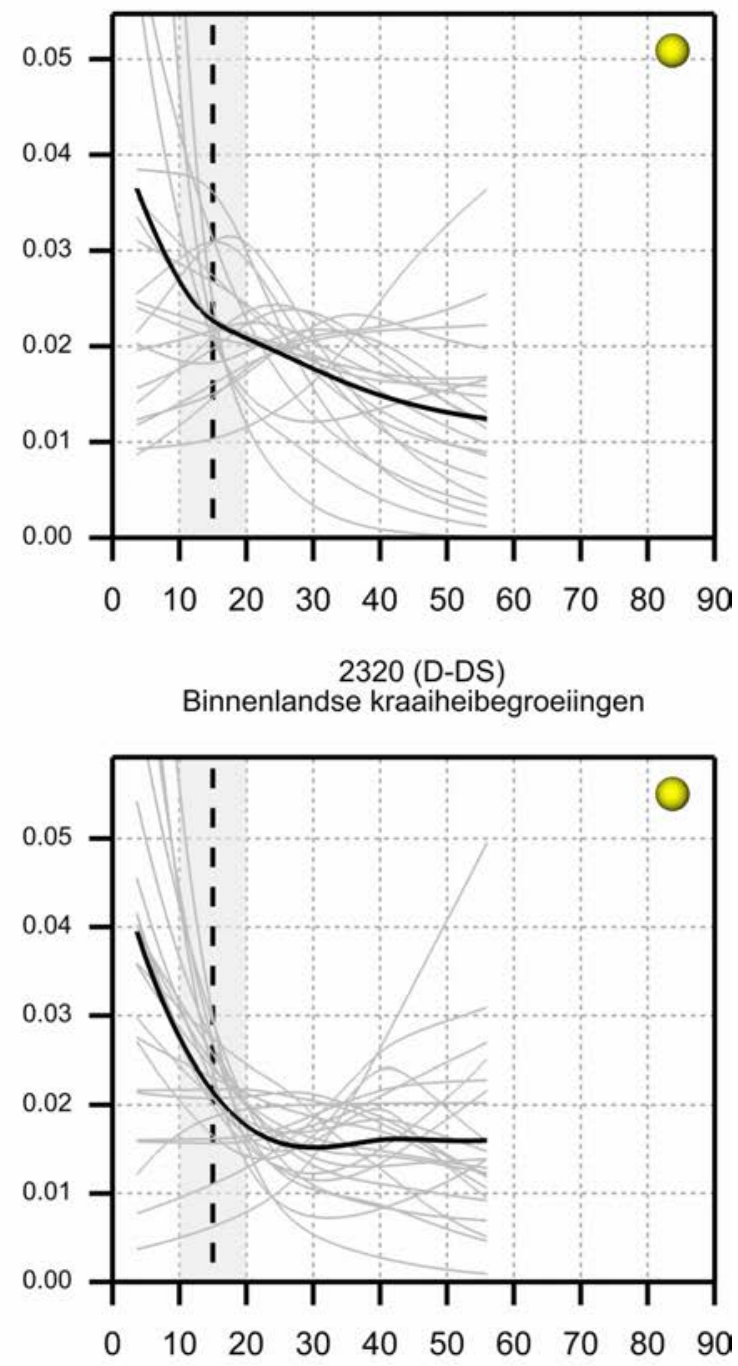

3110 (WAT)

Zeer zwakgebufferde vennen

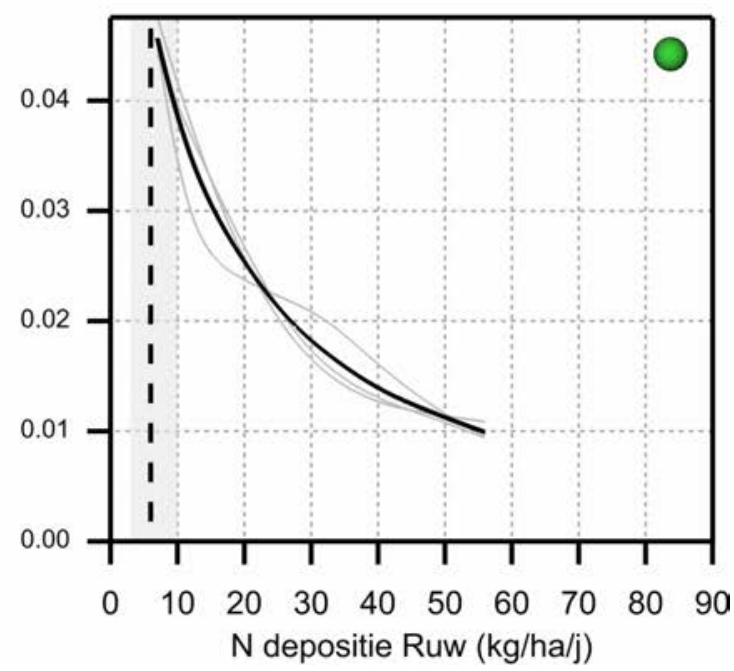

Figuur 44 Responscurven van habitattypen voor stikstofdepositie. De lichtgrijze lijnen geven de afzonderlijke curven van de kwalificerende soorten. De verticale gestippelde lijn geeft de KDW (Van Dobben et al., 2012), het grijze vak de empirische kritische depositiewaarde (Bobbink \& Hettelingh, 2011). In de kop wordt tussen haken het structuurtype gegeven (Tabel 2). De kleurcodering geeft de expertbeoordeling van de curve als in Tabel 11 (groen=goed, geel=matig, rood=slecht). 

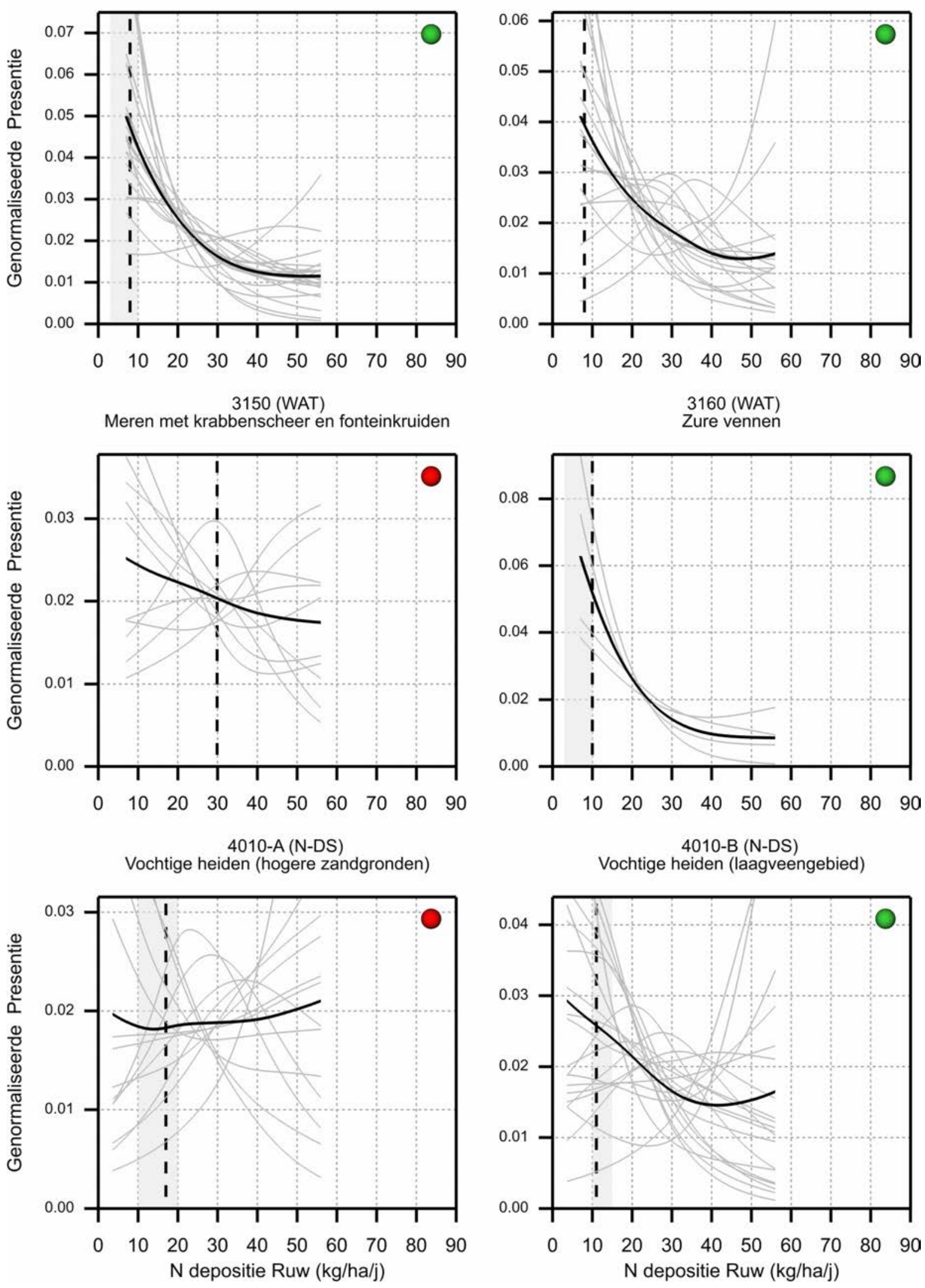

Figuur 45 Responscurven van habitattypen voor stikstofdepositie. De lichtgrijze lijnen geven de afzonderlijke curven van de kwalificerende soorten. De verticale gestippelde lijn geeft de KDW (Van Dobben et al., 2012), het grijze vak de empirische kritische depositiewaarde (Bobbink \& Hettelingh, 2011). In de kop wordt tussen haken het structuurtype gegeven (Tabel 2). De kleurcodering geeft de expertbeoordeling van de curve als in Tabel 11 (groen=goed, geel=matig, rood=slecht). 

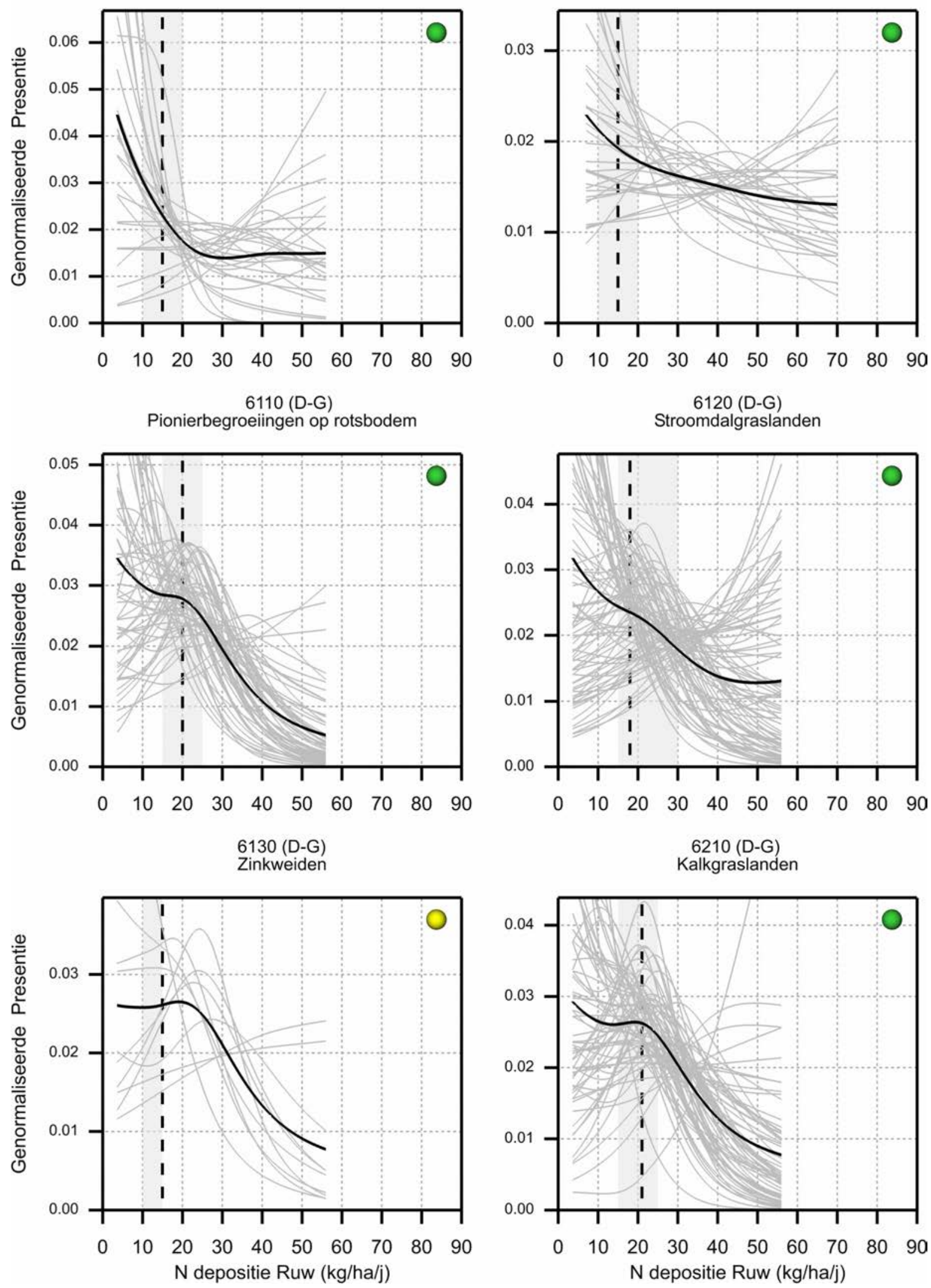

Figuur 46 Responscurven van habitattypen voor stikstofdepositie. De lichtgrijze lijnen geven de afzonderlijke curven van de kwalificerende soorten. De verticale gestippelde lijn geeft de KDW (Van Dobben et al., 2012), het grijze vak de empirische kritische depositiewaarde (Bobbink \& Hettelingh, 2011). In de kop wordt tussen haken het structuurtype gegeven (Tabel 2). De kleurcodering geeft de expertbeoordeling van de curve als in Tabel 11 (groen=goed, geel=matig, rood $=$ slecht). 
6230 (D-G)

Heischrale graslanden

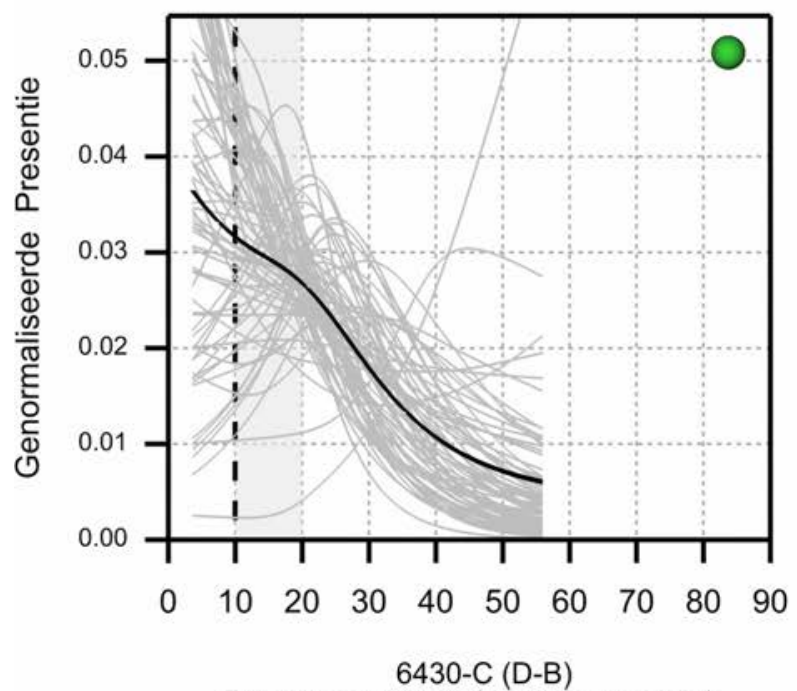

Ruigten en zomen (droge bosranden)

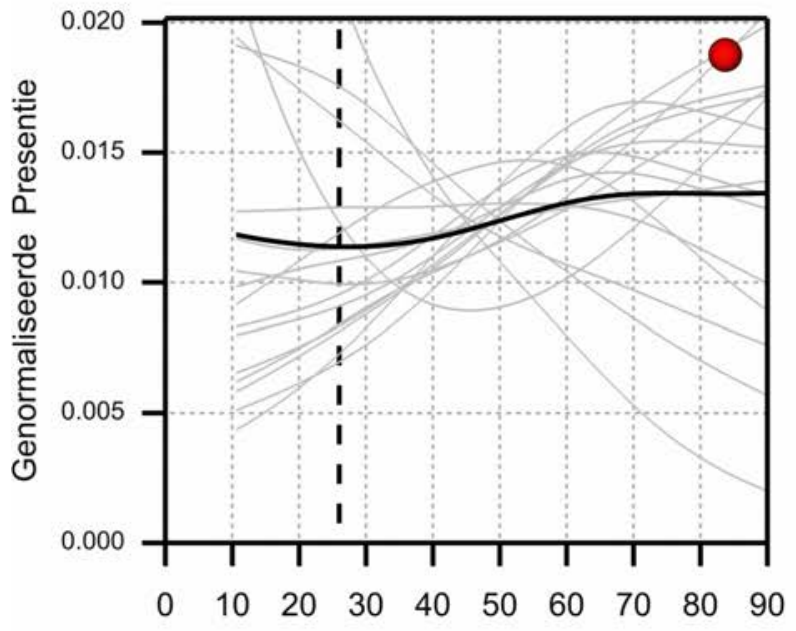

6510-B (D-G)

Glanshaver/vossenstaart hooiland (grote vossenstaart)

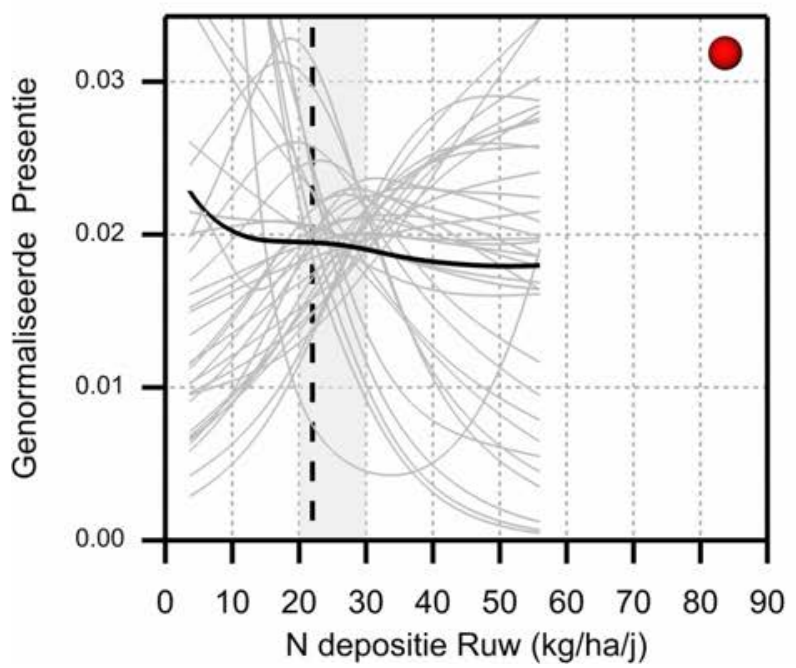

$6410(\mathrm{~N}-\mathrm{G})$

Blauwgraslanden

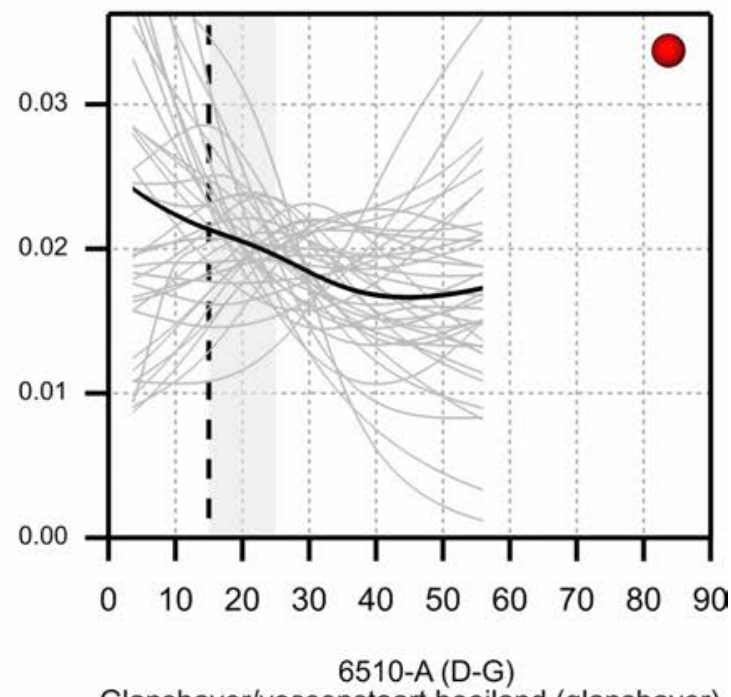

Glanshaver/vossenstaart hooiland (glanshaver)

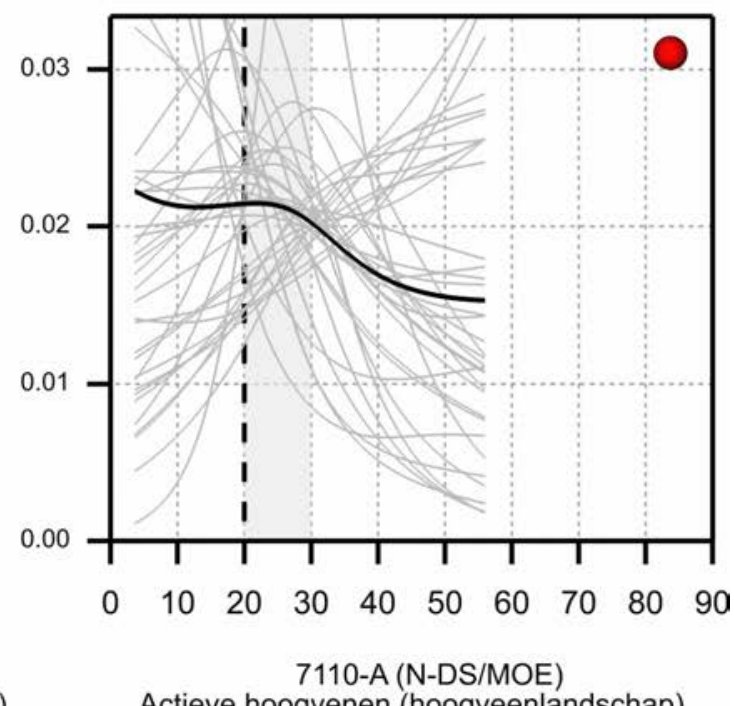

Actieve hoogvenen (hoogveenlandschap)

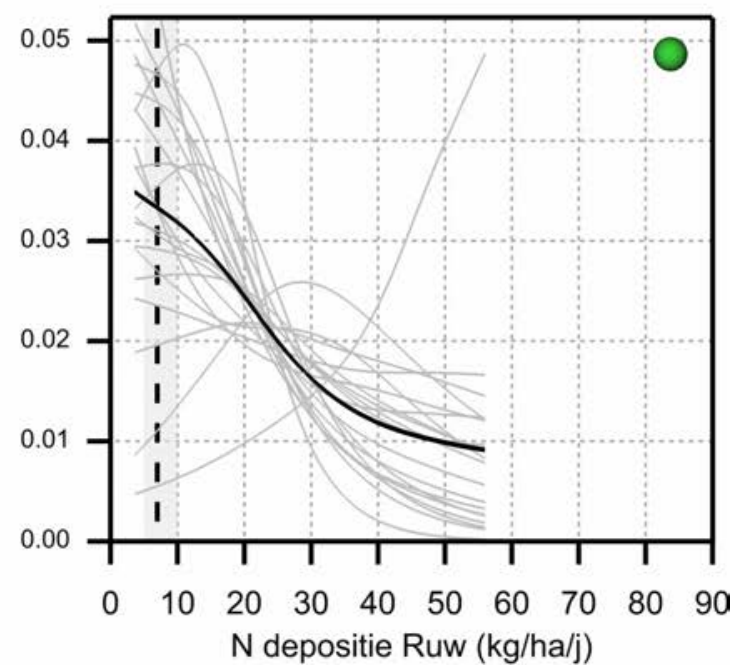

Figuur 47 Responscurven van habitattypen voor stikstofdepositie. De lichtgrijze lijnen geven de afzonderlijke curven van de kwalificerende soorten. De verticale gestippelde lijn geeft de KDW (Van Dobben et al., 2012), het grijze vak de empirische kritische depositiewaarde (Bobbink \& Hettelingh, 2011). In de kop wordt tussen haken het structuurtype gegeven (Tabel 2). De kleurcodering geeft de expertbeoordeling van de curve als in Tabel 11 (groen=goed, geel=matig, rood=slecht). 
7110-B (N-DS/MOE)

Actieve hoogvenen (heideveentjes)

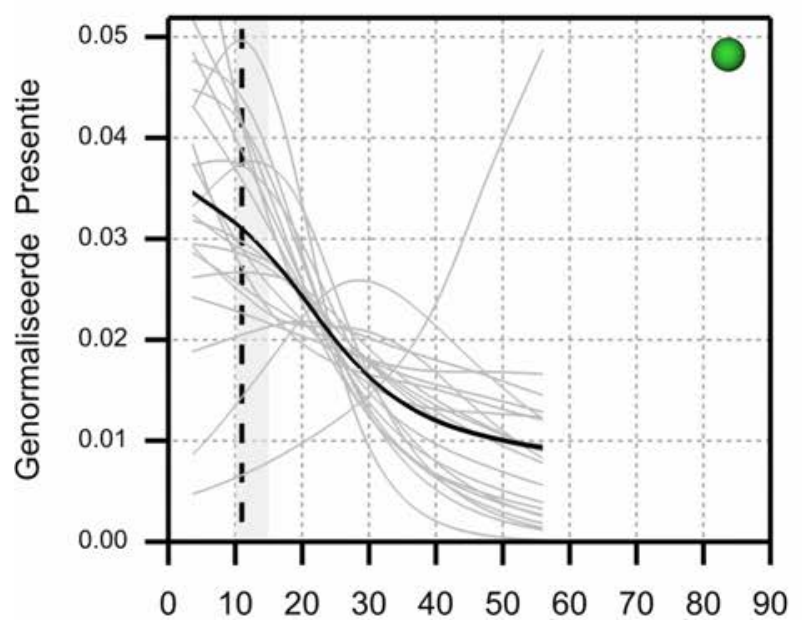

7140-A (MOE)

Overgangs- en trilvenen (trilvenen)

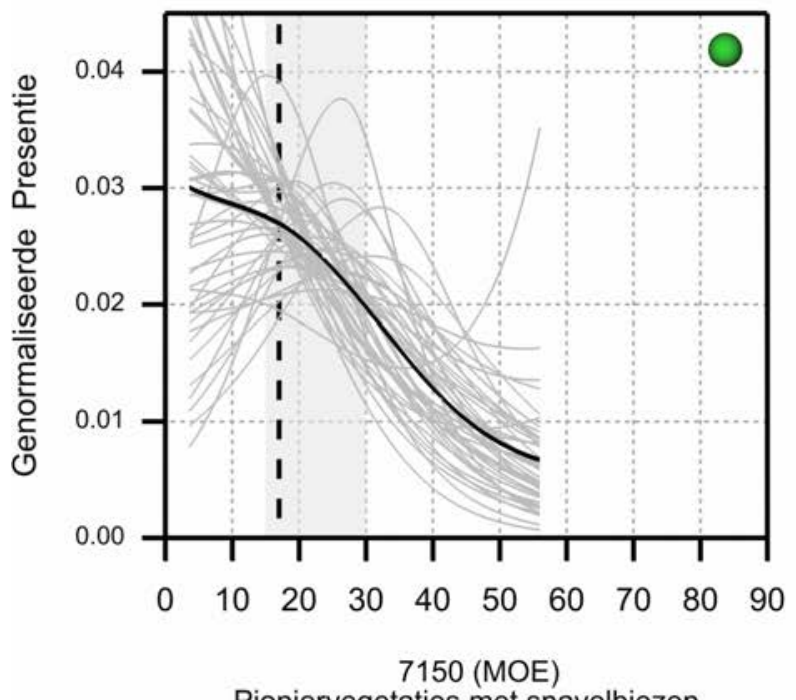

Pioniervegetaties met snavelbiezen

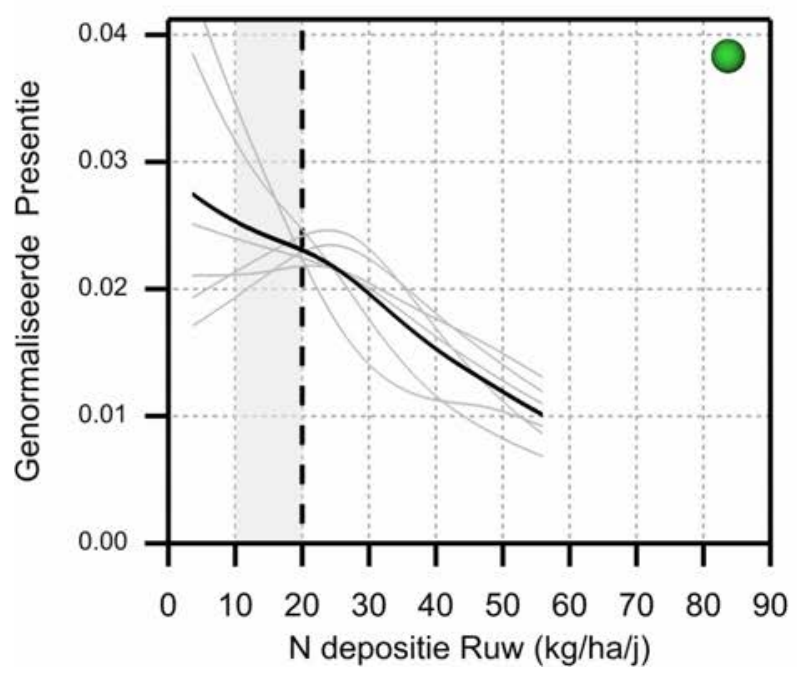

7120 (N-DS/MOE)

Herstellende hoogvenen

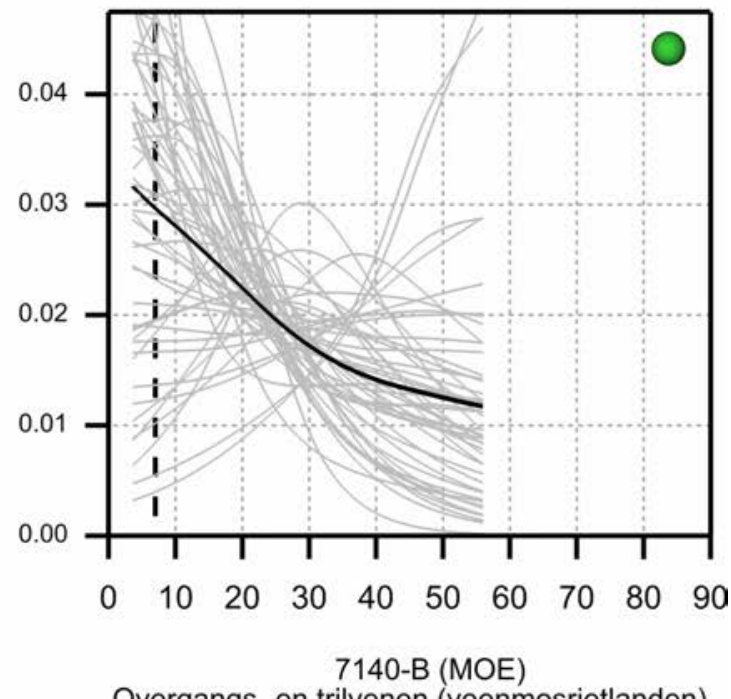

Overgangs- en trilvenen (veenmosrietlanden)
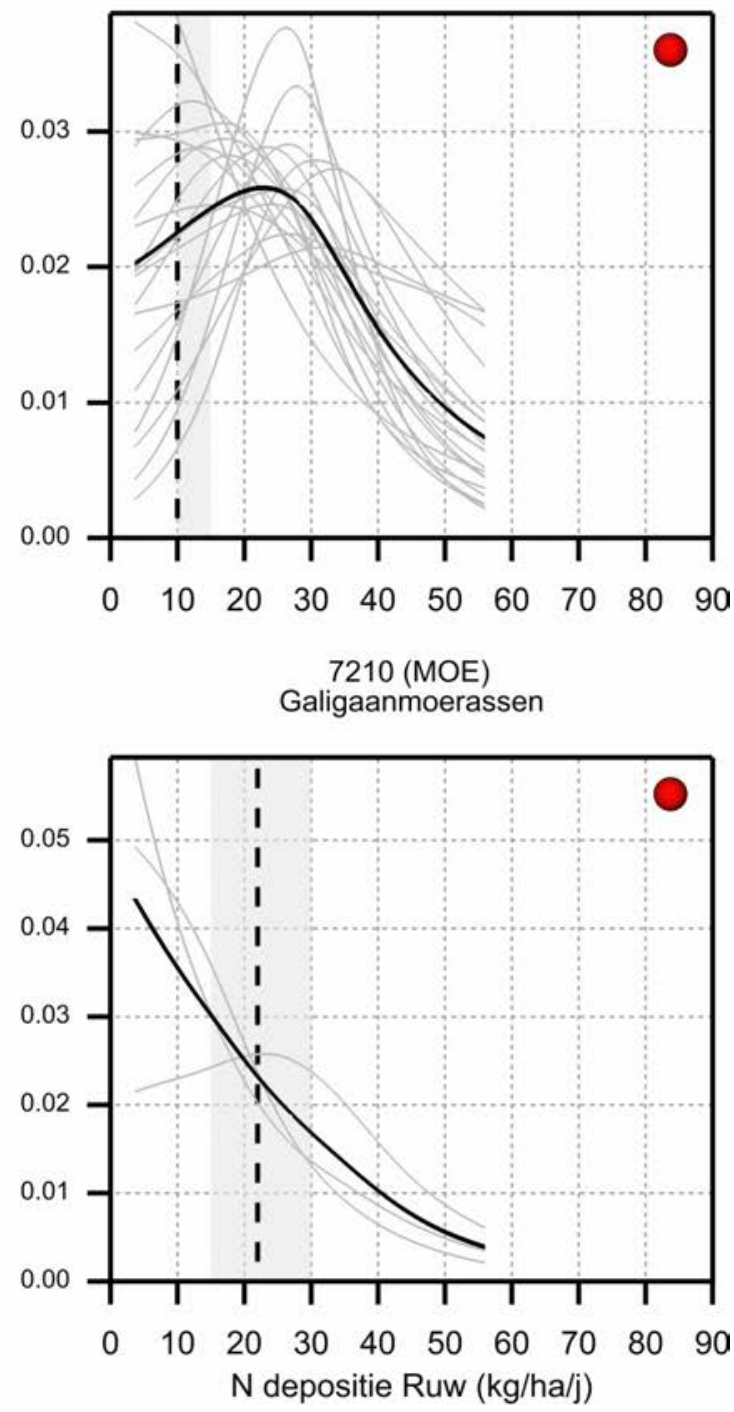

Figuur 48 Responscurven van habitattypen voor stikstofdepositie. De lichtgrijze lijnen geven de afzonderlijke curven van de kwalificerende soorten. De verticale gestippelde lijn geeft de KDW (Van Dobben et al., 2012), het grijze vak de empirische kritische depositiewaarde (Bobbink \& Hettelingh, 2011). In de kop wordt tussen haken het structuurtype gegeven (Tabel 2). De kleurcodering geeft de expertbeoordeling van de curve als in Tabel 11 (groen=goed, geel=matig, rood=slecht). 

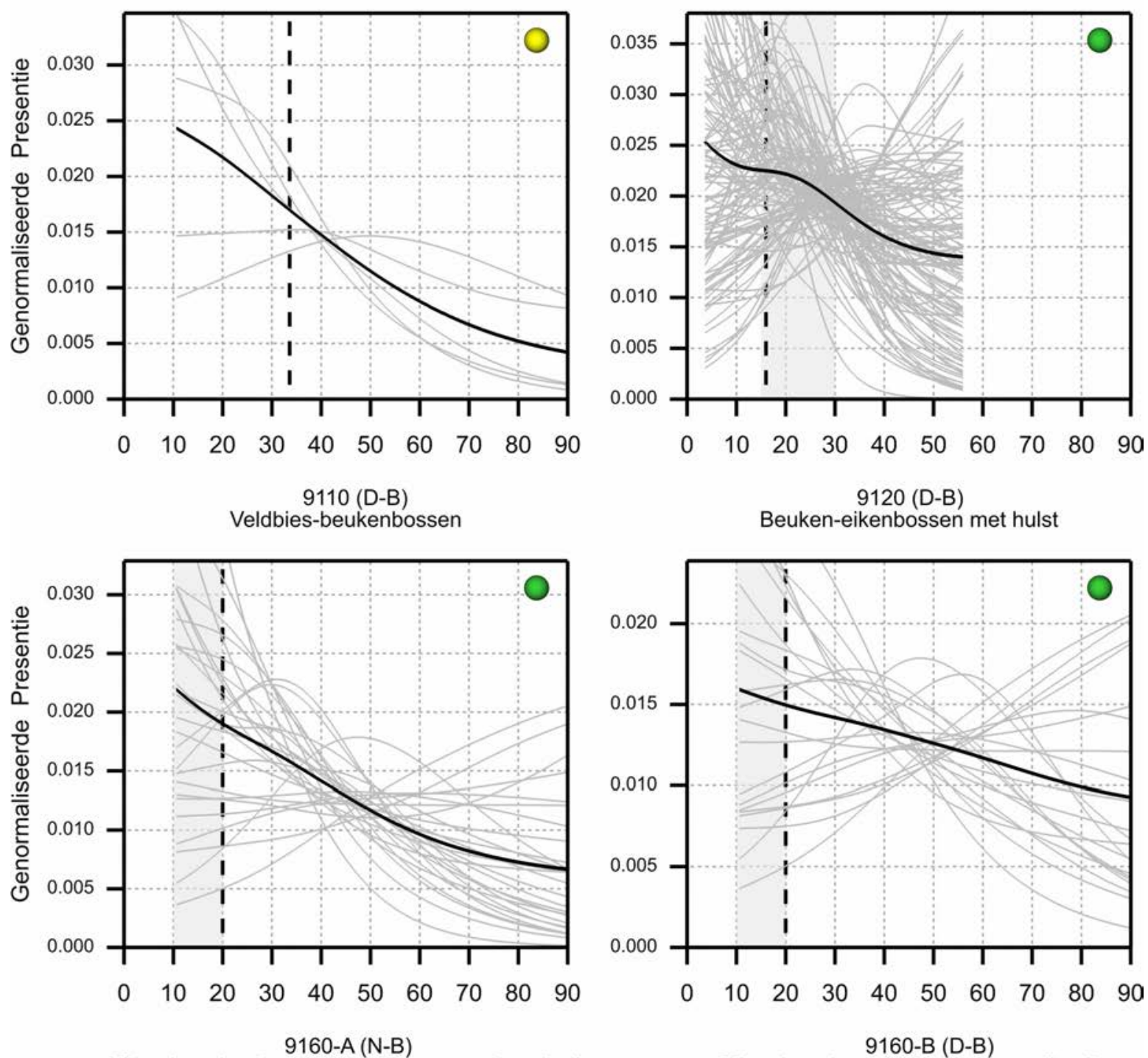

Eiken-haagbeukenbossen (hogere zandgronden)

Eiken-haagbeukenbossen (heuvelland)
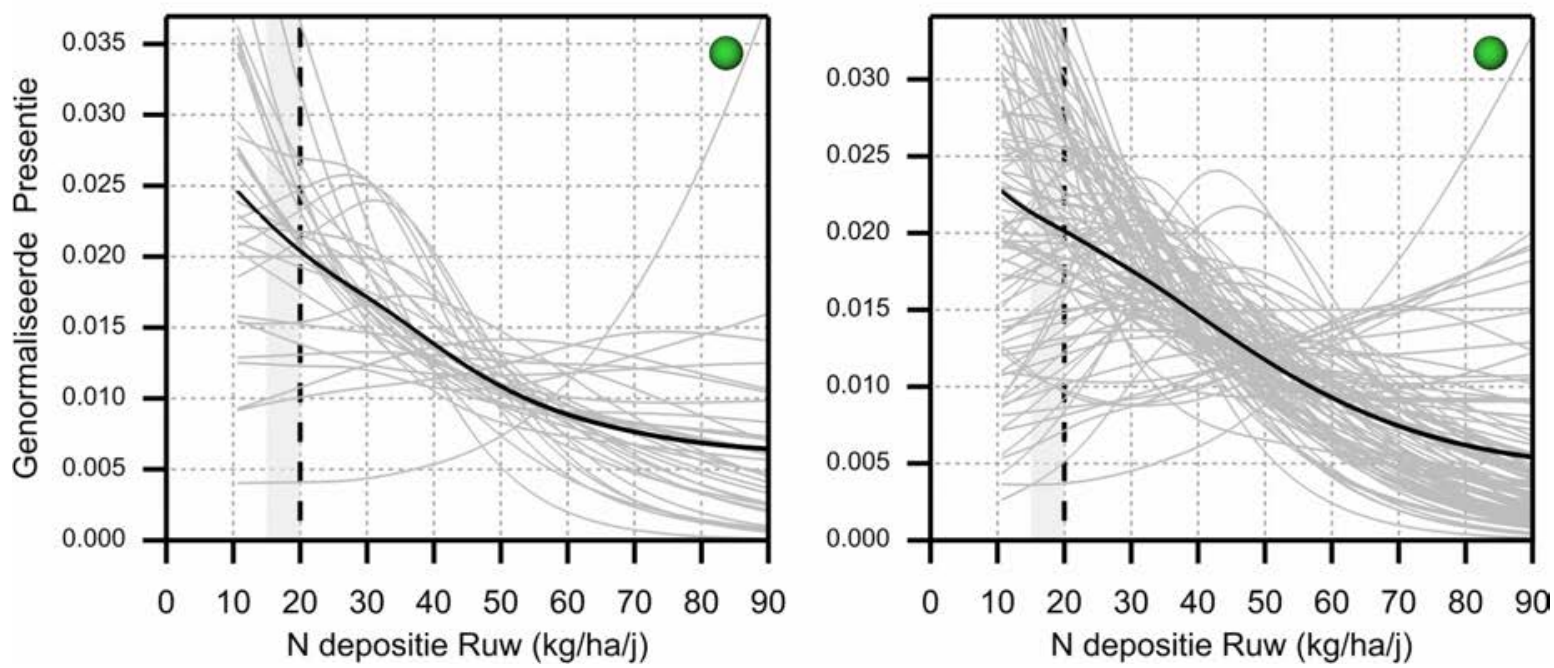

Figuur 49 Responscurven van habitattypen voor stikstofdepositie. De lichtgrijze lijnen geven de afzonderlijke curven van de kwalificerende soorten. De verticale gestippelde lijn geeft de KDW (Van Dobben et al., 2012), het grijze vak de empirische kritische depositiewaarde (Bobbink \& Hettelingh, 2011). In de kop wordt tussen haken het structuurtype gegeven (Tabel 2). De kleurcodering geeft de expertbeoordeling van de curve als in Tabel 11 (groen=goed, geel=matig, rood $=$ slecht). 
9190 (D-B)

Oude eikenbossen

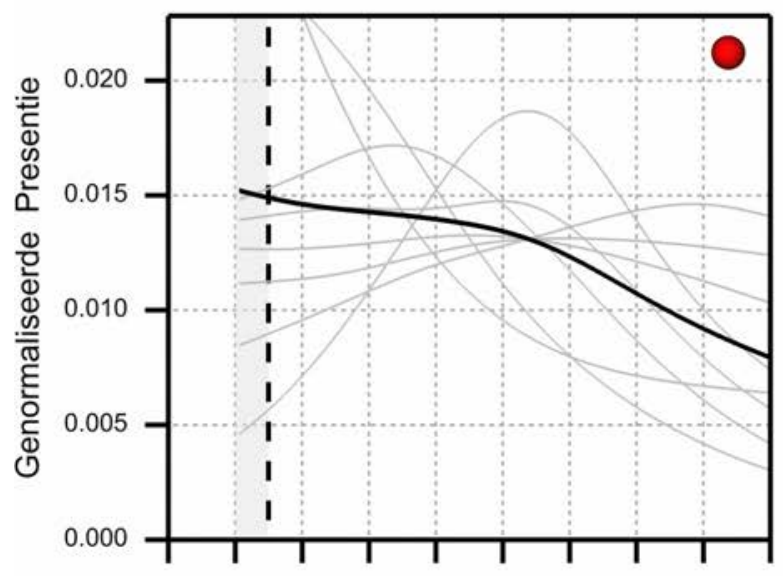

$\begin{array}{llllllllll}0 & 10 & 20 & 30 & 40 & 50 & 60 & 70 & 80 & 90\end{array}$

91E0-A (N-B)

Vochtige alluviale bossen (zachthoutooibossen)

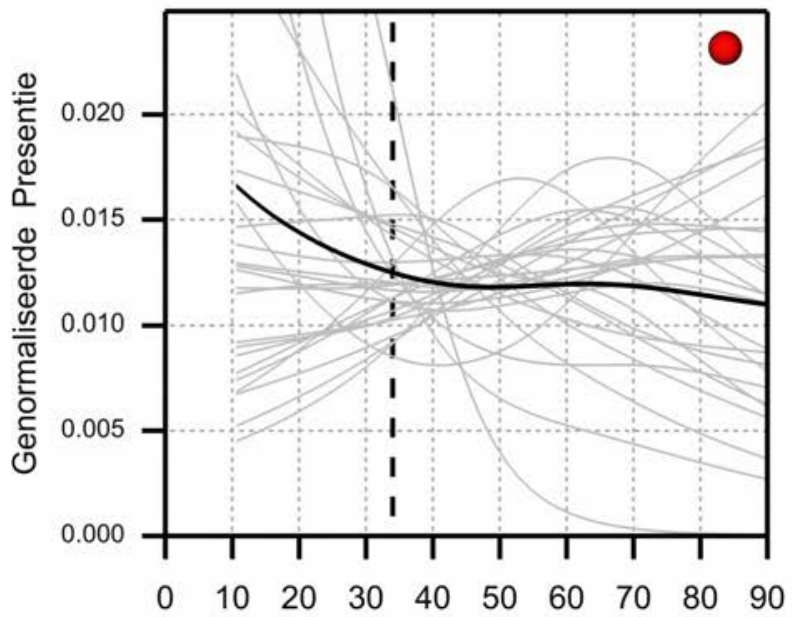

91E0-C (N-B)

Vochtige alluviale bossen (beekbegeleidende bossen)

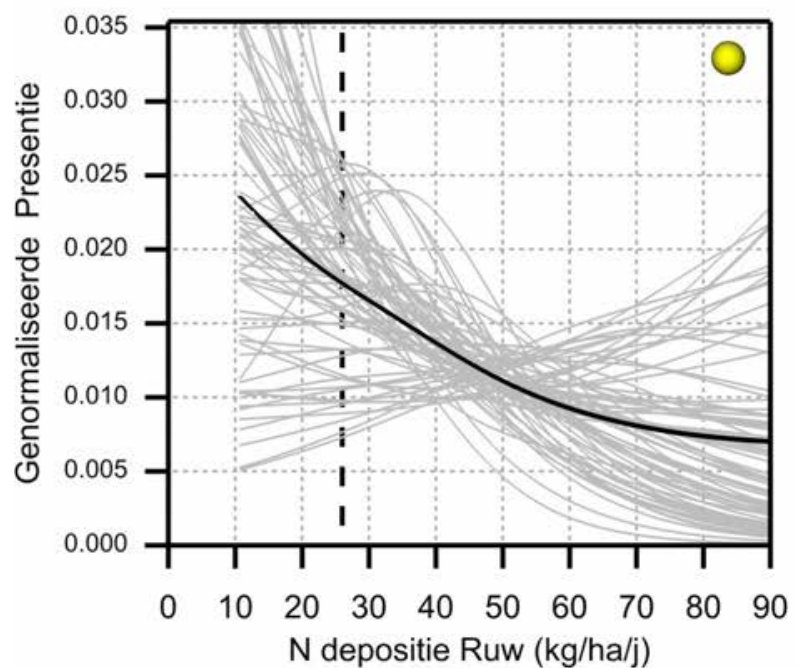

91D0 (N-B)

Hoogveenbossen

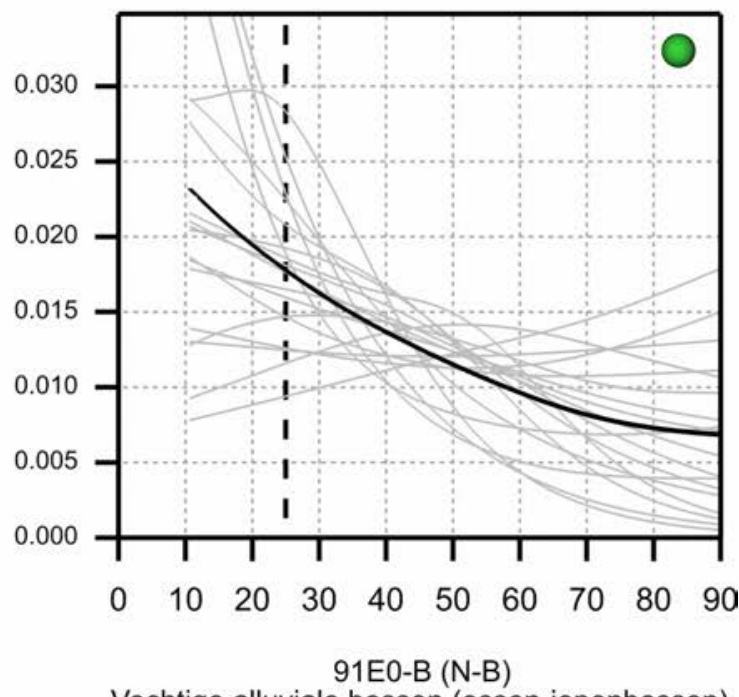

Vochtige alluviale bossen (essen-iepenbossen)
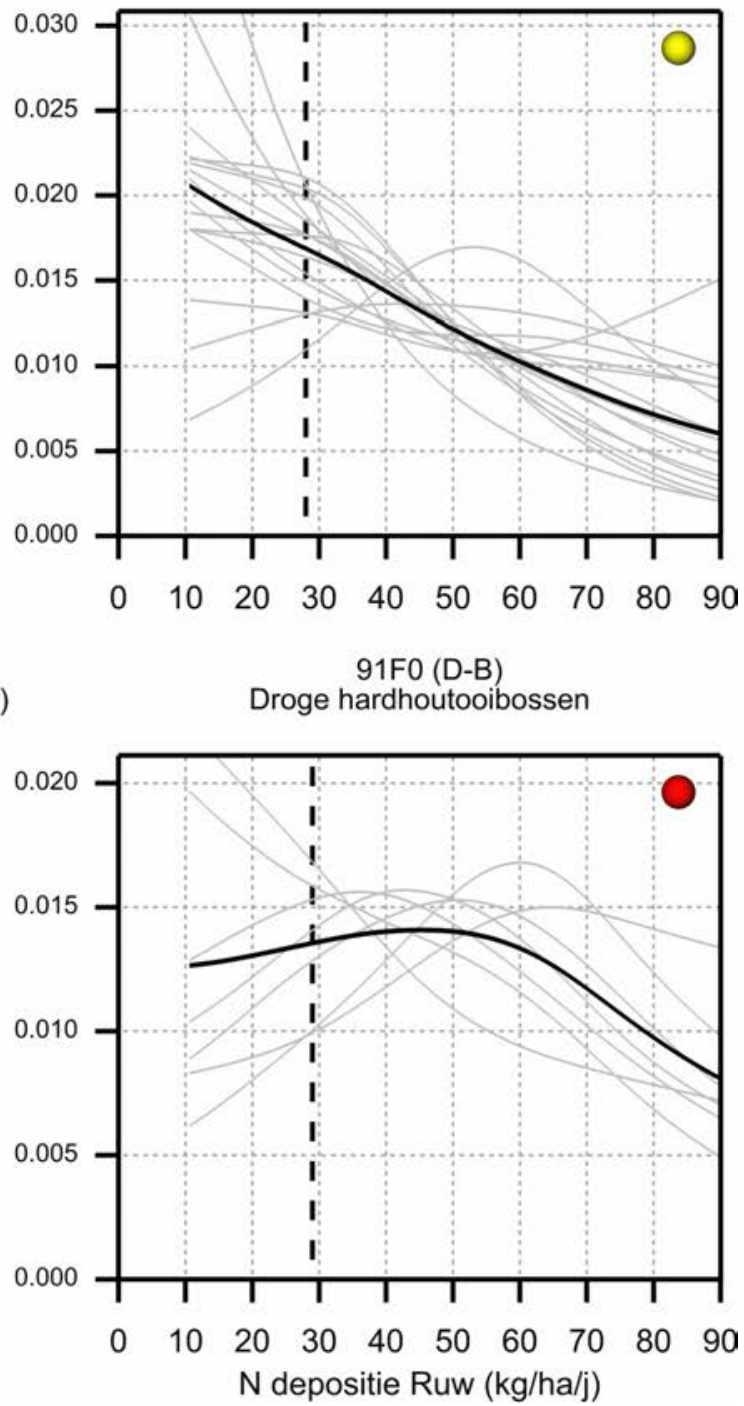

Figuur 50 Responscurven van habitattypen voor stikstofdepositie. De lichtgrijze lijnen geven de afzonderlijke curven van de kwalificerende soorten. De verticale gestippelde lijn geeft de KDW (Van Dobben et al., 2012), het grijze vak de empirische kritische depositiewaarde (Bobbink \& Hettelingh, 2011). In de kop wordt tussen haken het structuurtype gegeven (Tabel 2). De kleurcodering geeft de expertbeoordeling van de curve als in Tabel 11 (groen=goed, geel=matig, rood=slecht). 


\section{B.2.3 Discussie}

Door de enigszins arbitraire minimumeis van 100 vindplaatsen vallen 481 soort-structuurcombinaties af van de 2735 kwalificerende soort-structuurtype combinaties (Bijlage 8C). Dit gaat uiteraard vooral om zeldzame soorten. Dit heeft invloed op de responscurven, zeldzame soorten zijn vaak ook soorten die bedreigd worden door stikstofdepositie of zijn zelfs zeldzaam geworden door depositie. De afwezigheid van deze soorten zal naar verwachting de daling van de curve voor habitattypen verminderen.

De empirische en berekende KDW's, zoals gegeven door Van Dobben et al. (2012), zijn toegevoegd aan de responscurven en - voor zover beschikbaar - de daarin geciteerde empirische KDW's uit Bobbink \& Hettelingh (2011) voor de habitattypen (Figuur 42 tot en met Figuur 52). De verwachting is dat er een relatie is tussen de KDW's en de responscurven wat betreft het depositieniveau waarop afname van de kans op voorkomen van kwalificerende soorten plaatsvindt (niet wat betreft de verdere vorm van de curve). Een afname bij zowel een (veel) lagere depositie als bij een (veel) hogere depositie is reden om te twijfelen aan de plausibiliteit van de responscurve.

Daarnaast is er reden om ook naar andere aspecten van de vorm van de curve te kijken. Uit Deel A is al gebleken dat bij sommige typen in het lage depositietraject een beperkte stijging van het aantal soorten kan optreden en pas daarna een (sterke) daling. Daar kan een ecologische verklaring voor zijn. In deze verkenning is daarom bij het beoordelen van de plausibiliteit meegewogen of de berekende respons verklaard kan worden uit de ecologische processen in de betreffende habitat(sub)typen.

De responscurven voor de habitattypen zijn dus beoordeeld op plausibiliteit op basis van de relatie tot de KDW's en op basis van de verdere vorm van de curve, zie Tabel 11. De responscurve wordt als goed beoordeeld voor 37 habitattype van de in totaal 61 habitattypen. Voor 9 typen is de curve als matig beoordeeld, al zijn daar wel wat vraagtekens bij te zetten, bijvoorbeeld omdat de curve al scherp daalt voor de KDW (zie verder Tabel 11). Voor 14 habitattypen wordt de responscurve slecht geacht. Voor 1 type (2110) is geen responscurve geschat vanwege het ontbreken van kwalificerende soorten.

Na evaluatie van de curven voor de 9 typen die als matig en de 14 typen die als slecht zijn beoordeeld, lijkt het erop dat de verklaring vooral is gelegen in de respons van onderliggende soorten en dus in de selectie van de soorten die als kwalificerend zijn bestempeld. Een deel van de soorten profiteert van stikstofdepositie met een stijgende responscurve als resultaat. Als die soorten een groot deel uitmaken van de soortensamenstelling van een habitattype, dan werkt dat door in de responscurve van het habitattype, met als gevolg een stijgende responscurve. Voorbeelden zijn Ruigten en zomen (droge bosranden, 6430-C), Glanshaver- en vossenstaarthooilanden (grote vossenstaart, 6510-B) en Vochtige alluviale bossen (zachthoutooibossen, 91E0-A), waar de curve vooral vlak blijft. Dit geeft aan dat de soortenkeuze bepalend kan zijn voor het eindresultaat. Als de positieve respons vooral wordt veroorzaakt door verdringingssoorten, dan zou de soortenlijst daarop aangepast kunnen worden, analoog aan de bevindingen uit Deel A. Hiervoor is wel een wetenschappelijk onderbouwing nodig, die gebaseerd is op de daadwerkelijk plaatsvindende processen van het verdwijnen en verschijnen van soorten in de betreffende habitattypen onder verschillende depositieniveaus. Deze verkenning leende zich niet voor dergelijke aanpassingen van de soortenlijst. De 14 als slecht beoordeelde responscurven (zie Tabel 11) zijn momenteel niet bruikbaar om de respons van het type op stikstofdepositie te beoordelen. $\mathrm{Na}$ aanpassing van de lijst met kwalificerende soorten zouden deze curven opnieuw geschat kunnen worden. Overigens speelt dit probleem op een subtielere manier bij typen met een aanzienlijk aandeel kwalificerende soorten van voedselrijke omstandigheden: door deze soorten, die niet of weinig kenmerkend zijn voor het habitattype, kan het effect van stikstofdepositie worden gemaskeerd (zie ook Deel A). Als de responscurve daalt, is de curve weliswaar als goed beoordeeld, maar een scherpere selectie van kwalificerende soorten zou mogelijk hebben geleid tot een responscurve met een sterk dalende vorm.

Ook bij de koppeling van het habitattype aan het structuurtype (bepalend voor de opnamen die worden geselecteerd) zijn mogelijk problemen ontstaan. Ruigten en zomen in droge bosranden (6430-C) is gekoppeld aan structuurtype Droog loofbos (D-B), terwijl het misschien ook aan Droog grasland had moeten worden gekoppeld. Mogelijk dat voor Natte heide op hogere zandgronden (4010-A) toevoeging van structuurtype Nat grasland aan Nat dwergstruweel tot een betere schatting 
van de responscurve kan zorgen. Droge heide geeft wel een plausibele responscurve, maar een aantal onderliggende soorten geeft onverwachte curven. Dit is mogelijk op te lossen door er ook structuurtype Droog grasland aan te koppelen. De tijd ontbrak echter om in deze verkenning de gevolgen van dit soort aanpassingen te onderzoeken.

Idealiter zou er een koppeling gemaakt kunnen worden tussen vegetatieopnamen en habitattypen, zonder gebruik te maken van de grovere indeling in vegetatiestructuurtypen. Dan zou per habitattype direct een responscurve kunnen worden geschat op basis van de kwaliteit van de opname en wordt de curve ook beter vergelijkbaar met de empirische data zoals gepresenteerd in Deel A. Deze koppeling valt voor de Europese vegetatieopnamen nog niet te maken, maar het zou wel kunnen voor Nederland met behulp van het programma ASSOCIA (dat echter alleen toepasbaar is voor de Nederlandse samenstelling van plantengemeenschappen).

Voor een aantal kwalificerende (verdringings)soorten worden nu responscurven geschat die op het eerste gezicht niet logisch lijken. Dit geldt bijvoorbeeld voor Avenella flexuosa (voorheen Deschampsia flexuosa, Bochtige smele) en Molinia caerulea (Pijpenstrootje, zie Bijlage 8A) waarvan bekend is dat ze de heide sterk gaan domineren bij hoge depositieniveaus. Maar in plaats van een stijgende curve, vertonen deze soorten een dalende respons op stikstofdepositie in een aantal structuurtypen. Hoewel toename in bedekking niet hetzelfde is als toename van aanwezigheid (vestiging), is dit toch opmerkelijk. Voor deze twee soorten kan de verklaring liggen in het feit dat geen opnamen zijn geselecteerd uit graslanden in geval het habitattype niet tot dat structuurtype behoort. In dit onderzoek is gepoogd dit probleem voor het structuurtype dwergstruiken op te lossen door de sterk vergraste heiden aan het structuurtype toe te voegen. Dit heeft echter niet tot een wezenlijke verbetering geleid. Dit komt deels omdat het aantal opnamen dat werd toegevoegd beperkt was, ongeveer 10 procent van het totaalaantal opnamen. Voor Rubus (bramen) lijkt iets anders aan de hand en nader onderzoek moet uitwijzen wat de onverwachte respons veroorzaakt (Bijlage 8A). $R$. fruticosus (Gewone braam) is een verzameling van een paar honderd 'soorten', die mogelijk heel verschillend reageren op stikstofdepositie.

Een aantal kwalificerende soorten van zilte habitattypen neemt onverwacht toe bij toenemende stikstofdepositie. Hiervoor is nog geen verklaring gevonden.

Ook het aantal kwalificerende soorten per habitattype speelt een rol bij het schatten van een als betrouwbaar gekwalificeerde responscurve. Relatief veel habitattypen met onbetrouwbaar geachte responscurven hebben een beperkt aantal kwalificerende soorten. In dit onderzoek werd ingeschat dat vijf soorten de ondergrens zou zijn voor een betrouwbare curve, maar dat lijkt nu aan de lage kant: tien soorten lijkt een betere ondergrens. Dat wil niet zeggen dat typen met minder dan tien kwalificerende soorten geen betrouwbare curven kunnen geven. Echter: de kans is wel veel groter dat een of twee afwijkende soorten een grote invloed op het eindresultaat hebben en dat daardoor een habitatcurve als niet plausibel wordt beoordeeld. Daar staat tegenover dat het dan onmogelijk gaat worden om voor soortenarme habitattypen responscurven te berekenen. Er zal dus gezocht moeten worden naar maatwerk.

Voor sommige typen is een zeer grote daling in een zeer smalle range berekend. Voorbeelden hiervan zijn Witte duinen (2120) en Droge heiden (4030). Het omgekeerde komt ook voor, typen met juist een geleidelijke daling over een brede range. Voorbeelden hiervan zijn Jeneverbesstruwelen (5130), Veldbies-beukenbossen (9110) of Beuken-eikenbossen met hulst (9120). In hoeverre dat de werkelijkheid weerspiegelt, is nog niet met zekerheid te zeggen. Ook in dit opzicht kunnen de resultaten uit deze verkenning nog niet als definitief worden gezien. Zie verder de vergelijking van de resultaten van Deel $B$ met die van Deel $A$ in Deel $C$ van dit rapport.

Over het algemeen zal gelden dat hoe breder de geschatte range hoe langer, maar ook vaak geleidelijker, de effecten van verhoging van de stikstofdepositie doorgaan op de vegetatie. Elke daling in de depositie kan dan zorgdragen voor een betere situatie van het type en dus bijdragen aan de goede staat van instandhouding. Tenminste als de bij het habitattype behorende soorten nog terug kunnen komen vanuit de zaadbank of uit de omgeving. 
Zelfs wanneer het rechterdeel van de curve vlak verloopt, kan een verhoging van de depositie in dit deel van de curve nog steeds effect hebben. Het hogere stikstofgehalte in de vegetatie dat door de hoge depositie is veroorzaakt (Poikolainen et al., 2009), kan effect hebben op hogere trofieniveaus; de kwaliteit van de voedingsstoffen kan bijvoorbeeld veranderen. Heiden kunnen hierdoor gevoeliger worden voor het Heidehaantje door een hoger stikstofgehalte in de heide (Berdowski, 1987) waarna, na afsterven van de Struikhei, Pijpenstrootje de heide kan overnemen en andere langzaam groeiende soorten kan verdringen.

De hier gegeven curven zijn gebaseerd op een vereenvoudiging van de werkelijkheid. Hierdoor kunnen belangrijke factoren gemist worden, die de vorm van de curve kunnen beïnvloeden op een nu nog onbekende manier. Het gaat daarbij onder andere om fosfor (dat ook als drukfactor kan optreden), grondwaterstand/vochtbeschikbaarheid en het beheer van de vegetatie. Omdat er te weinig informatie hierover beschikbaar is op Europese schaal kunnen deze factoren niet worden meegenomen als covariabele in de responscurve.

Idealiter zou er een koppeling kunnen worden gemaakt tussen vegetatieopnamen en habitattypen. Dan zou per habitattype direct een responscurve kunnen worden geschat op basis van de kwaliteit van de opname en wordt de curve ook beter vergelijkbaar met de empirische data zoals verzameld in Deel A.

Voor een deel van de habitattypen wordt de daling van de responscurve al ingezet vóór de KDW bereikt is. In de meeste gevallen begint de daling al direct bij de ondergrens waarvoor de curve nog kan worden geschat. De vraag is in hoeverre deze resultaten overeenkomen met de werkelijkheid, aangezien een significante kwaliteitsvermindering weerspiegeld zou moeten worden in de (huidige) KDW's. De kennis op dit vlak staat echter niet stil. Uit deel A bleek al dat er in een deel van de gevallen aanleiding is om de resultaten van de gradiëntstudies te betrekken bij de revisie van de KDW-ranges die in voorbereiding is. Er zijn ook andere studies beschikbaar die hiervoor aanleiding geven. Voor habitattypen uit Noord-Europa worden KDW's geschat die direct boven de vermoedelijke achtergronddepositie liggen (Rosén et al. 1992). Mogelijk zijn daar al effecten op de vegetatie bij iedere extra kg antropogene stikstofdepositie (Fremstad et al. 2005). Een deel van de soorten die daar voorkomt, komt (of kwam) ook in Nederland voor en er is geen reden om aan te nemen dat ze hier minder gevoelig zouden zijn voor de effecten van stikstofdepositie.

Voor Ierland is een deels vergelijkbare studie uitgevoerd door Wilkins et al. (2016). Zij hebben ook gekeken naar de responsies van soorten met behulp van een andere statistische methode. Ook maakt die studie alleen gebruik van Ierse data en de daar voorkomende habitattypen. Zij geven geen responscurven voor soorten of habitattypen, maar stikstofdepositie ranges waarbinnen een soort kan voorkomen (zie hun Figuur 2). Zij concluderen dat voor een behoorlijk aantal "kwalificerende" soorten de bedreiging door stikstofdepositie al begint beneden de vastgestelde KDW. Dit komt overeen met de resultaten in deze studie. Recent vonden Payne et al. (2020) voor de zure graslanden onder andere een positieve reactie op stikstofdepositie van Nardus stricta (Borstelgras), zoals ook gevonden in dit onderzoek. Een verdergaande (statistische) vergelijking met deze onderzoeken zou zeer aanbevelingswaardig zijn.

Clarck et al. (2019) deden onderzoek naar de kwetsbaarheid van 348 plantensoorten voor stikstof- en zuurdepositie in de Verenigde Staten. Zij vonden dat $70 \%$ van de onderzochte soorten een negatief effect van de depositie op de kans op voorkomen ondervond. Een aanzienlijk deel van die soorten ondervond al negatieve effecten bij de laagste depositie $(3,1 \mathrm{~kg} / \mathrm{ha} / \mathrm{j}$. voor Groot-Brittannië) en vertoonden net als een groot deel van onze kwalificerende soorten een dalende kans op voorkomen ook bij zeer lage deposities. Ook vonden zij dat onder de dalers vooral soorten zaten van zogenaamde "higher-value native species" en onder de stijgers vooral invasieve soorten. Dit komt overeen met de resultaten van Wamelink et al. (2018). Net als in dit onderzoek vonden Clark et al. soorten met monotoon dalende responscurven, optimumcurven en soorten die een stijgende lijn vertoonden (hun Figuur 1).

Het MNP gebruikt momenteel een zeer simpele relatie tussen soorten en hun voorkomen bij verschillende stikstofdeposities. Nader onderzoek is noodzakelijk vooraleer de hier opgedane kennis in de toekomst kan worden toegepast in de modellering van het Milieu- en Natuurplanbureau (MNP). 
Tabel 11 Korte beschrijving van de responscurven per habitattype, de range waarover de curve daalt en de expertbeoordeling van de plausibiliteit als slecht, matig of goed. De beoordeling is uitgevoerd door de hoofdauteur.

\begin{tabular}{|c|c|c|c|c|}
\hline Habitat & Naam habitattype & Beschrijving curve & Range daling ( $\mathrm{kg} / \mathrm{ha} / \mathrm{j})$. & Beoordeling \\
\hline $1310-\mathrm{A}$ & Zilte pionierbegroeiingen (zeekraal) & $\begin{array}{l}\text { Stijgende curve. Slechts vijf kwalificerende soorten. Alle vijf de soorten } \\
\text { nemen toe in bedekking, wat onwaarschijnlijk lijkt. }\end{array}$ & & Slecht \\
\hline $1310-B$ & Zilte pionierbegroeiingen (zeevetmuur) & $\begin{array}{l}\text { Langzaam dalende curve, met een knik naar een sterkere daling net } \\
\text { beneden de KDW. }\end{array}$ & 35 & Goed \\
\hline 1320 & Slijkgrasvelden & $\begin{array}{l}\text { Slechts één kwalificerende soort (Spartina anglica), die een onbegrijpelijke } \\
\text { respons geeft (hyperbool, met het laagste deel bij de KDW). }\end{array}$ & & Slecht \\
\hline 1330-A & Schorren en zilte graslanden (buitendijks) & $\begin{array}{l}\text { Licht dalende curve met een knik naar een steiler dalend deel net voor de } \\
\text { KDW. }\end{array}$ & 20 & Goed \\
\hline $1330-B$ & Schorren en zilte graslanden (binnendijks) & $\begin{array}{l}\text { Licht dalende curve met een knik naar een steiler dalend deel net voor de } \\
\text { KDW. }\end{array}$ & 15 & Goed \\
\hline 2110 & Embryonale duinen & Geen kwalificerende soorten. & & \\
\hline 2120 & Witte duinen & $\begin{array}{l}\text { Vanaf het begin scherp dalende curve, die zijn laagste punt bij de hoogste } \\
\text { depositie bereikt. Sterkste daling ruim voor de laagste empirische KDW, dus } \\
\text { te snelle daling. De sterke daling wordt vooral veroorzaakt door Eryngium } \\
\text { maritimum (Blauwe zeedistel) en Calystegia soldanella (Zeewinde). Blauwe } \\
\text { zeedistel staat weliswaar op de Rode Lijst, maar lijkt niet heel gevoelig voor } \\
\text { voedselrijkdom gegeven zijn Ellenbergwaarden-range. Hetzelfde geldt voor } \\
\text { Zeewinde. Mogelijk speelt successie een rol bij de vorm van de curve. }\end{array}$ & 15 & Matig \\
\hline 2130-A & Grijze duinen (kalkrijk) & $\begin{array}{l}\text { Dalende curve met een knik rond de KDW, blijvende daling tot hoogste } \\
\text { depositie. }\end{array}$ & 50 & Goed \\
\hline 2130-B & Grijze duinen (kalkarm) & Gestaag dalende curve, die bij hoge depositie iets afvlakt. & 40 & Goed \\
\hline $2130-\mathrm{C}$ & Grijze duinen (heischraal) & Dalende curve met voorbij de KDW een knikje. & 40 & Goed \\
\hline 2140-A & Duinheiden met kraaihei (vochtig) & $\begin{array}{l}\text { Dalende curve met een knikje rond de KDW, blijvende daling tot hoogste } \\
\text { depositie. }\end{array}$ & 40 & Goed \\
\hline 2140-B & Duinheiden met kraaihei (droog) & $\begin{array}{l}\text { Vrij sterk dalende curve die net voorbij de KDW afvlakt. De grootste daling } \\
\text { vindt plaats voor de KDW. Een aantal Cladonia-soorten en Viola canina } \\
\text { (Hondsviooltje) zorgen voor de vrij sterke daling. }\end{array}$ & 20 & Goed \\
\hline 2150 & Duinheide met struikhei & $\begin{array}{l}\text { Vrij sterk dalende curve die net voorbij de KDW afvlakt. De grootste daling } \\
\text { vindt plaats voor de KDW. Vooral een aantal Cladonia-soorten zorgt voor de } \\
\text { scherpe daling. }\end{array}$ & 20 & Goed \\
\hline
\end{tabular}




\begin{tabular}{|c|c|c|c|c|}
\hline Habitat & Naam habitattype & Beschrijving curve & Range daling ( $\mathrm{kg} / \mathrm{ha} / \mathrm{j})$. & Beoordeling \\
\hline 2160 & Duindoornstruwelen & $\begin{array}{l}\text { Gestaag dalende lijn over de hele depositie range. KDW is relatief hoog, } \\
\text { maar dat komt niet tot uiting in de curve. Een breed spectrum aan soorten, } \\
\text { met ook een aantal dat direct negatief reageert op depositie. }\end{array}$ & 65 & Matig \\
\hline 2170 & Kruipwilgstruwelen & $\begin{array}{l}\text { Eerst sterk dalende curve, daarna steeds verder afvlakkend. Daling vindt al } \\
\text { plaats ruim voor de KDW, die relatief hoog is. Het type heeft vier } \\
\text { kwalificerende soorten. Empetrum nigrum (Kraaihei) en Luzula multiflora } \\
\text { (Veelbloemige veldbies) reageren zoals past bij de KDW, Schoenus } \\
\text { nigricans (Knopbies) laat een scherpe daling zien, passend bij een soort die } \\
\text { sterk is achteruitgegaan. Door het geringe aantal soorten wordt de curve nu } \\
\text { wel als slecht gescoord. }\end{array}$ & 35 & Slecht \\
\hline 2180-A & Duinbossen (droog) & $\begin{array}{l}\text { Licht dalende curve over de hele range en een lage KDW. Er werd een } \\
\text { sterker dalende curve verwacht. Avenella flexuosa (Bochtige smele) } \\
\text { vertoont geen reactie op stikstofdepositie, wat onverklaarbaar is. Verder } \\
\text { veel soorten, waarvan een aantal, niet onverwacht, sterk toeneemt: } \\
\text { Frangula alnus (Sporkehout), Holcus mollis (Gladde witbol, mogelijk een } \\
\text { verdringingssoort) en Sorbus aucuparia (Wilde lijsterbes). }\end{array}$ & 85 & Matig \\
\hline 2180-B & Duinbossen (vochtig) & $\begin{array}{l}\text { Sterke daling zet al ver in voor de KDW, maar daalt na de KDW nog door, } \\
\text { waarna de curve afvlakt. Geen empirische KDW. Veel kwalificerende } \\
\text { soorten. }\end{array}$ & 55 & Goed \\
\hline $2180-\mathrm{C}$ & Duinbossen (binnenduinrand) & $\begin{array}{l}\text { Zeer lichte daling voor de KDW, net na de KDW wordt de daling sterker om } \\
\text { daarna weer af te vlakken. }\end{array}$ & 50 & Goed \\
\hline 2190-A & Vochtige duinvalleien (open water) & Sterk dalende curve rond de KDW, die later afvlakt en stabiliseert. & 30 & Goed \\
\hline 2190-B & Vochtige duinvalleien (kalkrijk) & $\begin{array}{l}\text { Lichte daling gevolgd door een stabilisatie rond de KDW. Na de KDW dalend } \\
\text { tot einde range. Veel kwalificerende soorten. }\end{array}$ & 35 & Goed \\
\hline $2190-\mathrm{C}$ & Vochtige duinvalleien (ontkalkt) & $\begin{array}{l}\text { Sterke daling voor de KDW, net voor de KDW een knik naar een meer } \\
\text { geleidelijke daling tot einde range. De snelle daling bij de lage depositie } \\
\text { wordt vooral veroorzaakt door Empetrum nigrum (Kraaihei) en Scorpidium } \\
\text { scorpiodes (Rood schorpioenmos). Vooral voor de laatste soort, die zeer } \\
\text { zeldzaam en behoorlijk gevoelig is, is dat logisch. }\end{array}$ & 50 & Matig \\
\hline 2310 & Stuifzandheiden met struikhei & $\begin{array}{l}\text { Sterke daling voor de KDW, gevolgd door een stabilisatie net voorbij de } \\
\text { hoogste waarde van de empirische KDW-range. De scherpe daling bij lage } \\
\text { depositie wordt vooral veroorzaakt door een aantal Cladonia-soorten. }\end{array}$ & 20 & Goed \\
\hline 2320 & Binnenlandse kraaiheibegroeiingen & $\begin{array}{l}\text { Sterke daling voor de KDW, gevolgd door een stabilisatie net voorbij de } \\
\text { hoogste waarde van de empirische KDW-range. De snelle daling is vooral } \\
\text { een samenspel van een groot deel van de soorten. }\end{array}$ & 20 & Matig \\
\hline
\end{tabular}




$\begin{array}{ll}\text { Habitat } & \text { Naam habitattype } \\ 2330 & \text { Zandverstuivingen }\end{array}$

$$
3110
$$

Zeer Zwakgebufferde vennen

$$
3130
$$

Zwakgebufferde vennen

$$
3140
$$

Kranswierwateren

Meren met krabbenscheer en fonteinkruiden

$$
3160
$$

Zure vennen

$$
\text { 4010-A }
$$

Vochtige heiden (hogere zandgronden)
Beschrijving curve

Geleidelijk dalende respons over de hele range, iets sterker dalend voorbij

Range daling ( $\mathrm{kg} / \mathrm{ha} / \mathrm{j}$.

$20 \mathrm{~kg} / \mathrm{ha} / \mathrm{j}$.

Dalende lijn over de hele range. De KDW ligt lager dan het

40

50

Beoordeling

geldigheidsgebied van de curve. Slechts drie kwalificerende soorten, alle

drie dalend op vergelijkbare wijze.

Afvlakkende dalende lijn. De KDW ligt lager dan het geldigheidsgebied van

de curve. Een aantal soorten heeft een lagere ondergrens dan voor het type wordt aangehouden.

Dalende curve die bij de hoogste depositie zeer licht omhooggaat. De KDW

ligt lager dan het geldigheidsgebied van de curve. Zie ook 3130. Isolepis fluitans (Vlottende bies) heeft een S-vormige curve.

Licht dalende curve, die bij hogere depositie wat afvlakt. Vrij hoge KDW, grootste daling vindt plaats lager dan de KDW. Wellicht is het beeld niet

heel slecht, maar Stratiotes aloides (Krabbenscheer) vertoont een gestaag

dalende lijn, opvallend voor een soort van relatief voedselrijk water.

Sterke daling bij lagere deposities, daarna afvlakkend. Vier kwalificerende

soorten met een vergelijkbare dalende curve. Twee soorten beginnen de

curve bij de KDW, met een dalende lijn.

Licht stijgende curve. Lichte daling voor de KDW. Onverwachte stijgende

curven voor bijvoorbeeld Drosera intermedia (Kleine zonnedauw), Erica

tetralix (Gewone dophei), Gentiana pneumonanthe (Klokjesgentiaan) en

Sphagnum compactum (Kussentjesveenmos). De curve voor Molinia

caerulea (Pijpenstrootje) loopt daarentegen nauwelijks op. Alle

soortresponsies zijn geschat voor structuurtype natte dwergstruiken.

Waarschijnlijk missen hierdoor de vergraste heiden, die binnen EUNIS als grasland worden gekwalificeerd.

Dalende curve, daarna afvlakkend en bij hoge depositie licht omhooggaand.

Sterke daling bij lage depositie, ook al voor de KDW, daarna afvlakkend.

Geleidelijk dalende curve. De verschillen zijn relatief klein. De grootste

daling vindt plaats binnen de empirische KDW-range.

Dalende lijn, gevolgd door een stabilisatie rond de KDW, om daarna sterk verder te dalen.

30

30

40

30

Goed

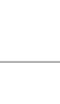

35

20

65

50

35
Goed

Goed

Goed

Slecting

$6120 \quad$ Stroomdalgraslanden

Dalende lijn, bij hogere depositie afvlakkend. 


\begin{tabular}{|c|c|c|c|c|}
\hline Habitat & Naam habitattype & Beschrijving curve & Range daling (kg/ha/j.) & Beoordeling \\
\hline 6130 & Zinkweiden & $\begin{array}{l}\text { Voorbij de KDW dalende lijn. De meest kenmerkende zinksoorten ontbreken } \\
\text { door te weinig waarnemingen. Het resultaat wordt bepaald door relatief } \\
\text { algemene soorten. }\end{array}$ & 35 & Matig \\
\hline 6210 & Kalkgraslanden & $\begin{array}{l}\text { Curve met een licht dalend begin, gevolgd door een stabilisatie rond de } \\
\text { KDW en daarna sterk dalend. }\end{array}$ & 35 & Goed \\
\hline 6230 & Heischrale graslanden & $\begin{array}{l}\text { Dalende curve, met een zeer lichte afvlakking in de range van de } \\
\text { empirische KDW. }\end{array}$ & 50 & Goed \\
\hline 6410 & Blauwgraslanden & $\begin{array}{l}\text { Licht dalende curve die aan het einde heel licht oploopt. De verwachting is } \\
\text { een veel scherpere daling. De respons van Rhinanthus angustifolius (Grote } \\
\text { ratelaar) is onverwacht stijgend. Carum verticillatum (Kranskarwij) heeft } \\
\text { een zeer beperkt bereik. De meeste soorten reageren min of meer } \\
\text { indifferent op stikstofdepositie. Wellicht spelen in dit type andere processen } \\
\text { die belangrijker zijn, zoals kwel en de kwaliteit daarvan die niet worden } \\
\text { meegenomen als covariabele. }\end{array}$ & 35 & Slecht \\
\hline $6430-\mathrm{C}$ & Ruigten en zomen (droge bosranden) & $\begin{array}{l}\text { Licht stijgende curve. Stijging begint voorbij de KDW. Ruigten en zomen } \\
\text { (droge bosranden) is gekoppeld aan structuurtype bos. Dit kan tot te hoge } \\
\text { berekende deposities en responsies van soorten hebben geleid. Veel zeer } \\
\text { algemene soorten van voedselrijke milieus bepalen de curve: Aegopodium } \\
\text { podagraria (Zevenblad), Anthriscus sy/vestris (Fluitenkruid), Galium aparine } \\
\text { (Kleefkruid), Glechoma hederacea (Hondsdraf), Lamium album (Witte } \\
\text { dovenetel), Rumex obtusifolius (Ridderzuring), Silene dioica } \\
\text { (Dagkoekoeksbloem) en Urtica dioica (Grote brandnetel). De meest } \\
\text { karakteristieke soorten binnen het habitatsubtype zijn juist (zeer) } \\
\text { zeldzaam. }\end{array}$ & & Slecht \\
\hline $6510-\mathrm{A}$ & $\begin{array}{l}\text { Glanshaver- en vossenstaarthooilanden } \\
\text { (glanshaver) }\end{array}$ & $\begin{array}{l}\text { Initieel vlakke lijn, gevolgd door een daling na de KDW, maar binnen de } \\
\text { empirische KDW. Geen duidelijke respons op de depositie en daarom als } \\
\text { slecht beoordeeld. }\end{array}$ & 30 & Slecht \\
\hline $6510-B$ & $\begin{array}{l}\text { Glanshaver- en vossenstaarthooilanden } \\
\text { (grote vossenstaart) }\end{array}$ & $\begin{array}{l}\text { Vrijwel vlak lopende curve, alleen in het begin lichte daling. Verschillen zijn } \\
\text { zeer gering. Een deel van de soorten is kenmerkend voor voedselrijke } \\
\text { graslanden en deze hebben een grote invloed op de curve. }\end{array}$ & & Slecht \\
\hline 7110-A & Actieve hoogvenen (hoogveenlandschap) & Vanaf de lage KDW een dalende curve die bij hoge depositie afvlakt. & 50 & Goed \\
\hline 7110-B & Actieve hoogvenen (heideveentjes) & Vanaf de lage KDW een dalende curve die bij hoge depositie afvlakt. & 50 & Goed \\
\hline 7120 & Herstellende hoogvenen & Vanaf de lage KDW een dalende curve die bij hoge depositie afvlakt. & 50 & Goed \\
\hline 7140-A & Overgangs- en trilvenen (trilvenen) & $\begin{array}{l}\text { Dalende curve, die bij hoge depositie enigszins afvlakt. In het begin is de } \\
\text { daling relatief gering, maar voorbij de KDW sterker. }\end{array}$ & 50 & Goed \\
\hline
\end{tabular}




\begin{tabular}{|c|c|c|c|c|}
\hline Habitat & Naam habitattype & Beschrijving curve & Range daling ( $\mathrm{kg} / \mathrm{ha} / \mathrm{j})$. & Beoordeling \\
\hline $7140-B$ & $\begin{array}{l}\text { Overgangs- en trilvenen } \\
\text { (veenmosrietlanden) }\end{array}$ & $\begin{array}{l}\text { Optimumcurve, met een toename tot ver voorbij de KDW. Daling hierna is } \\
\text { weliswaar vrij sterk, maar zet pas bij te hoge depositie in. Veel soorten } \\
\text { vertonen optimumcurven die veel op elkaar lijken en dus ook op de } \\
\text { uiteindelijke curve voor het type. Er is geen verklaring voor deze respons. }\end{array}$ & 30 & Slecht \\
\hline 7150 & Pioniervegetaties met snavelbiezen & Dalende curve over de gehele range. & 50 & Goed \\
\hline 7210 & Galigaanmoerassen & $\begin{array}{l}\text { Sterk dalende curve, zowel beneden als boven de KDW. KDW ligt midden in } \\
\text { de daling. Slechts drie kwalificerende soorten, waarvan twee Cladium } \\
\text { mariscus, (Galigaan) en Myrica gale, (Wilde gagel) een sterk dalende lijn } \\
\text { vertonen. Thelypteris palustris (Moerasvaren) heeft een curve die goed bij } \\
\text { de KDW zou passen. Voor Galigaan, een soort in matig voedselrijk water, } \\
\text { zou een wat minder steile curve verwacht kunnen worden. De KDW is } \\
\text { gebaseerd op soorten van kalkmoerassen (gezien de Europese definitie) en } \\
\text { die ontbreken nu in de soortenselectie. }\end{array}$ & 50 & Slecht \\
\hline 7220 & Kalktufbronnen & $\begin{array}{l}\text { Dalende curve. Daling ook ruim voor de KDW. Wellicht is de KDW te hoog } \\
\text { vastgesteld en behoeft deze een nadere beschouwing, ook vergeleken met } \\
\text { de kalkmoerassen. Vijf kwalificerende soorten. }\end{array}$ & 70 & Matig \\
\hline 7230 & Kalkmoerassen & $\begin{array}{l}\text { Dalende curve met een stabilisatie rond de KDW. De daling is niet erg } \\
\text { groot. De curve is gebaseerd op zeer veel kwalificerende soorten. Ook hier } \\
\text { de vreemde toename van Rhinanthus angustifolius (Grote ratelaar) bij } \\
\text { hogere stikstofdepositie. Ook hier veel soorten die een toename vertonen, } \\
\text { omdat het soorten zijn die bij voedselrijke omstandigheden horen. Het } \\
\text { effect wordt gedempt door de vele andere soorten die nadelige gevolgen } \\
\text { ondervinden van een toename in stikstofdepositie. }\end{array}$ & 50 & Goed \\
\hline 9110 & Veldbies-beukenbossen & $\begin{array}{l}\text { Ligt dalende curve over de gehele range. Curve vlakt enigszins af bij hogere } \\
\text { depositie. }\end{array}$ & 70 & Goed \\
\hline 9120 & Beuken-eikenbossen met hulst & $\begin{array}{l}\text { Ligt dalende curve over de gehele range. De benedengrens van de } \\
\text { empirische KDW ligt iets lager. }\end{array}$ & 75 & Goed \\
\hline 9160-A & $\begin{array}{l}\text { Eiken-haagbeukenbossen (hogere } \\
\text { zandgronden) }\end{array}$ & Ligt dalende curve, die enigszins afvlakt bij hogere depositie. & 70 & Goed \\
\hline $9160-B$ & Eiken-haagbeukenbossen (heuvelland) & Dalende curve over de gehele range. & 75 & Goed \\
\hline
\end{tabular}




\begin{tabular}{|c|c|c|c|c|}
\hline Habitat & Naam habitattype & Beschrijving curve & Range daling ( $\mathrm{kg} / \mathrm{ha} / \mathrm{j})$. & Beoordeling \\
\hline 9190 & Oude eikenbossen & $\begin{array}{l}\text { Licht dalende curve, die na } 60 \mathrm{~kg} / \mathrm{ha} / \mathrm{j} . \text { sterker daalt. De daling is echter } \\
\text { beperkt en de curve is daarom als slecht beoordeeld. De vorm van de curve } \\
\text { zou kunnen kloppen. De meeste soorten vertonen nauwelijks een effect, } \\
\text { uitgezonderd Melampyrum pratense (Hengel) en Polytrichum formosum } \\
\text { (Fraai haarmos), beide met een daling. Avenella flexuosa (Bochtige smele) } \\
\text { vertoont ook hier nauwelijks een positieve reactie op stikstofdepositie. }\end{array}$ & 40 & Slecht \\
\hline 91D0 & Hoogveenbossen & $\begin{array}{l}\text { Dalende curve, die bij hoge depositie afvlakt. Daling begint ruim voor de } \\
\text { KDW. De snelle daling wordt vooral veroorzaakt door Eriophorum } \\
\text { vaginatum (Eenarig wollegras), Vaccinium oxycoccos (Kleine veenbes) en } \\
\text { Vaccinium vitis-idaea (Rode bosbes). Het verdwijnen van sommige soorten } \\
\text { kan ook met het dichtgroeien en donkerder worden van het bos te maken } \\
\text { hebben. Het dichtgroeien kan worden gestimuleerd door depositie. }\end{array}$ & 70 & Goed \\
\hline 91E0-A & $\begin{array}{l}\text { Vochtige alluviale bossen } \\
\text { (zachthoutooibossen) }\end{array}$ & $\begin{array}{l}\text { Daling vooral voor de KDW, daarna vlak. De verschillen zijn klein. De } \\
\text { geringe daling en verschillen worden veroorzaakt door een aantal soorten } \\
\text { dat toeneemt bij hogere depositie, Galeopsis tetrahit (Gewone } \\
\text { hennepnetel), Galium palustre (Moeraswalstro), Iris pseudocorus (Gele lis), } \\
\text { Salix alba (Schietwilg) en Urtica dioica (Grote brandnetel), soorten van } \\
\text { stikstofrijke omstandigheden. Overigens is het type 'niet/ minder gevoelig' } \\
\text { volgens Van Dobben et al. (2012), dus een daling is onverwacht. }\end{array}$ & 30 & \\
\hline 91E0-B & $\begin{array}{l}\text { Vochtige alluviale bossen (essen- } \\
\text { iepenbossen) }\end{array}$ & $\begin{array}{l}\text { Dalende lijn over de gehele range, ook voor de KDW. Een deel van de } \\
\text { soorten vertoont een curve die goed past bij de KDW. De daling voor de } \\
\text { KDW wordt vooral veroorzaakt door Eurhynchium striatum (Geplooid } \\
\text { snavelmos) en in mindere mate door Fissidens taxifolius (Kleivedermos), } \\
\text { Geum urbanum (Geel nagelkruid) en Rumex sanguineus (Bloedzuring). }\end{array}$ & 85 & Matig \\
\hline 91E0-C & $\begin{array}{l}\text { Vochtige alluviale bossen } \\
\text { (beekbegeleidende bossen) }\end{array}$ & Dalende lijn, die bij hoge depositie afvlakt. & 65 & Matig \\
\hline 91F0 & Droge hardhoutooibossen & $\begin{array}{l}\text { Optimumcurve, pas dalend na } 50 \mathrm{~kg} / \mathrm{ha} / \mathrm{j} . \mathrm{KDW} \text { ligt veel lager. Zeven } \\
\text { kwalificerende soorten, vijf daarvan vertonen een optimumcurve en twee, } \\
\text { Poa nemoralis (Schaduwgras) en Viola odorata (Maarts viooltje), vanaf het } \\
\text { begin een dalende curve. }\end{array}$ & 40 & Slecht \\
\hline
\end{tabular}




\section{B.3 Responscurven voor habitattypen op basis van verdringingssoorten}

Door stikstofdepositie en de daaruit volgende toename in stikstofbeschikbaarheid en verzuring veranderen de abiotische omstandigheden waarvan soorten kunnen profiteren die daaraan zijn aangepast. Dit kan zowel plaatsvinden voor een deel van de type-eigen soorten als voor type-vreemde soorten. Als deze soorten al aanwezig zijn, kunnen ze zich uitbreiden. En als ze in de zaadbank of in de omgeving voorkomen, kunnen ze zich vestigen. Zij gaan dan de concurrentie met de overige soorten aan. Onder niet-overbelaste omstandigheden zouden deze soorten nauwelijks of geen kans krijgen.

Soorten die snel groeien en veel blad vormen, zijn bij stikstofdepositie in het voordeel en kunnen minder snelgroeiende soorten overwoekeren. Langzamere groeiers zullen dan (op termijn) verdwijnen. Een bekend voorbeeld is de invasie van natte heide door pijpenstrootje, waardoor een deel van de kenmerkende soorten, zoals orchideeën en veenmossen, verdwijnt. Deze toenemende soorten zijn in principe te gebruiken als indicatoren voor de veranderende omstandigheden als gevolg van stikstofdepositie en dit kan eerder zichtbaar zijn dan het verdwijnen van soorten. In dit hoofdstuk wordt onderzocht of deze zogenoemde verdringingssoorten als indicatoren kunnen dienen voor een toenemende stikstofdepositie.

Verdringingssoorten zijn als volgt gedefinieerd: een verdringingssoort reageert op stikstofdepositie door zodanig sterk toe te nemen in bedekking dat andere soorten (met name kwalificerende soorten) daardoor worden verdrongen en (dreigen te) verdwijnen. In dit onderzoek zijn verdringingssoorten geselecteerd uit de soortgroepen vaatplanten (inclusief bomen), mossen of korstmossen. Soorten die profiteren van stikstofdepositie, maar niet zodanig toenemen dat zij andere soorten verdringen, behoren niet tot de verdringingssoorten. Deze zogenoemde storingssoorten zijn dus niet geselecteerd.

De verwachting is dat de verdringingssoorten bij toenemende stikstofdepositie zullen toenemen in bedekking. Daarom zijn er responscurven voor verdringingssoorten geschat op basis van de bedekking, waarbij grotendeels gebruik is gemaakt van dezelfde methode voor het schatten van de responscurven voor de aanwezigheid van kwalificerende soorten.

\section{B.3.1 Materiaal en methoden}

Voor het selecteren van de verdringingssoorten per habitattype is gebruikgemaakt van verschillende bronnen. Er is enerzijds gebruikgemaakt van de herstelstrategieën waarin verdringingssoorten worden genoemd (Smits et al., 2016). Anderzijds is gebruikgemaakt van Oosterlynck et al. (2020), waarin vele soorten worden genoemd die profiteren van verzuring en/of eutrofiëring. Het nadeel van deze publicatie is dat niet wordt vermeld of deze soorten zodanig tot dominantie komen dat ze kwalificerende soorten verdringen. Dat onderscheid is belangrijk, omdat niet elke storingssoort een verdringingssoort is. Daarom zijn zowel op basis van expertkennis (ook van leden van de begeleidingscommissie) als op basis van tussentijdse resultaten veel soorten uit deze publicatie alsnog geschrapt.

Voor de selectie van verdringingssoorten zijn de volgende criteria gebruikt:

1. Een verdringingssoort wordt voor een bepaald habitattype geselecteerd. Mocht de soort ook in een ander type voorkomen, dan wordt deze niet automatisch voor dat type als verdringingssoort aangemerkt.

2. Er wordt geen onderscheid gemaakt tussen type-eigen verdringingssoorten, de zogenaamde kwalificerende verdringingssoorten, en soorten die niet tot het type behoren, maar daarin binnendringen. Een voorbeeld van een kwalificerende verdringingssoort is pijpenstrootje in droge heide.

3. Verdringingssoorten uit de herstelstrategieën (Smits et al., 2016) zijn integraal overgenomen.

4. Door Oosterlynck et al. (2020) zijn de volgende criteria opgesteld op basis waarvan de door hen genoemde soorten al dan niet kunnen worden geselecteerd:

4a. 'Vergrassingssoorten' zijn overgenomen.

4b. 'Verzuringssoorten' zijn overgenomen omdat stikstofdepositie een verzurend effect heeft.

4c. 'Eutrofiëringssoorten' zijn overgenomen. 
4d. 'Invasieve exoten' zijn niet overgenomen, met uitzondering van Campylopus introflexus (Grijs kronkelsteeltje), waarvan is aangetoond dat hij andere soorten verdringt (Sparrius, 2011). Een deel van de invasieve exoten kan wellicht profiteren van stikstofdepositie, maar vooralsnog is niet aangetoond dat er sprake is van verdringing als gevolg van stikstofdepositie.

4e. 'Verdrogingssoorten' zijn niet overgenomen, hoewel er een indirecte link kan zijn met vermesting. Dit gaat bijvoorbeeld om de afbraak van organisch materiaal dat ook tot vermesting leidt, maar niet direct een gevolg is van stikstofdepositie.

4f. 'Vernattingssoorten' zijn niet overgenomen.

4g. Oosterlynck et al. geven soms alleen geslachtsnamen. In dat geval zijn geen soorten overgenomen, met uitzondering van Typha ( $T$. latifolia en $T$. angustifolia) en Holcus $(H$. mollis en $H$. lanatus), omdat zij als verdringingssoorten kunnen optreden.

4h. Wieren en schimmels zijn niet overgenomen.

$4 i$. Struiken en bomen zijn overgenomen voor zover sprake is van successie die kan worden versneld door stikstofdepositie.

4j. Als 'verbraming' wordt genoemd, dan is Rubus fruticosus (Gewone braam) opgenomen als verdringingssoort en niet Rubus idaeus (Dauwbraam), tenzij die expliciet wordt vermeld.

$4 \mathrm{k}$. In enkele gevallen wordt verstruiking door dwergstruiken als een probleem genoemd, maar dat proces kan als gevolg van stikstofdepositie hooguit plaatsvinden bij lage depositiewaarden en is dus niet relevant als indicatie voor de gevolgen van hoge depositiewaarden.

Oosterlynck et al. (2020) is niet compleet voor Nederland; een aantal habitattypen ontbreekt en er worden geen subtypen onderscheiden. In dat laatste geval zijn voor subtypen dezelfde soorten als verdringingssoort overgenomen. Ontbrekende typen zijn 6110, 6210, 7110-B, 7120 en 91D0. Voor 7220 worden alleen draadalgen genoemd als eutrofiëringssoorten, maar deze behoren niet tot de geselecteerde soortgroepen.

Op basis van bovengenoemde criteria zijn in eerste instantie 156 verdringingssoorten geselecteerd (Bijlage 8B). Uit de lijst van 156 soorten zijn per habitattype de duidelijkste verdringingssoorten geselecteerd. Daarmee viel een deel van de soorten uit Oosterlynck et al. (2020) alsnog af. Dit zijn soorten die een sterke toename in bedekking laten zien als gevolg van toenemende stikstofdepositie. Voor deze soorten zijn responscurven geschat. Deze curven zijn vervolgens geëvalueerd en soorten die volgens de berekeningen niet minimaal $10 \%$ toenemen in bedekking, zijn verwijderd; daar zitten ook soorten bij waarvan bekend is dat ze wel degelijk verdringingssoort zijn. Daarnaast is de lijst van kwalificerende soorten geëvalueerd en zijn soorten die meer dan 10 procentpunt toenemen in bedekking en zich ook daadwerkelijk gedragen als verdringingssoort alsnog toegevoegd aan de lijst. Dit leverde uiteindelijk een lijst van 123 verdringingssoorten op voor 55 typen. De lijst met verdringingssoorten is samengevoegd met de lijst met kwalificerende soorten en is te vinden in Bijlage 8B.

Als onderdeel van de evaluatie is nader gekeken naar een deel van de bossen. Bij sommige bostypen zijn alsnog geen responscurven voor verdringingssoorten opgenomen, omdat een toename van bepaalde soorten ook verklaard zou kunnen worden door veroudering van het bos en omdat een toename van bijvoorbeeld bepaalde (micro)soorten binnen de soort Rubus fruticosus (Gewone braam) geen problemen voor de habitatkwaliteit vormt (dat kan ook gelden voor de toename van andere soorten). Voor de matig voedselrijke wateren geldt dat instroom van voedselrijk water een logischer verklaring is voor toename van bepaalde soorten dan stikstof uit depositie.

Voor elke verdringingssoort is een responscurve geschat, deels analoog aan het schatten van responscurven voor de kwalificerende soorten. De afwijkingen zijn de volgende: het gaat in dit geval niet om aan- of afwezigheid, maar om bedekking. Het percentage bedekking is alleen van toepassing bij vegetatieopnamen waar de verdringingssoort aanwezig is (er zijn geen nulwaarnemingen meegenomen). De responscurve voor een habitattype wordt verkregen door de curven van de onderliggende soorten te sommeren (omdat het om het gestapelde effecten van meerdere verdringingssoorten gaat) en de responscurven zijn daarbij niet genormaliseerd. De basisselectie van vegetatieopnamen is dezelfde als voor de kwalificerende soorten. 
De geschatte responscurven zijn ten slotte per habitattype beoordeeld (expertinschatting) op plausibiliteit door de curven af te zetten tegen de KDW (inclusief de empirische KDW-range) en het verdere verloop van de curve. Theoretisch zou de bedekking van de verdringingssoorten en dus van het type laag moeten zijn bij lage depositie en moeten toenemen bij hogere depositie. De stijging kan al inzetten voor deposities beneden de KDW, maar een groot deel van de stijging zou plaats moeten vinden bij deposities hoger dan de KDW.

\section{B.3.2 Resultaten responscurven op basis van verdringingssoorten}

Voor alle habitattypen (61) worden de resultaten gegeven in Figuur 53 tot en met Figuur 63. De responscurven per type en soort zijn te vinden in Bijlage 8A. Voor sommige habitattypen wordt geen curve gegeven, bijvoorbeeld als er geen verdringingssoorten geselecteerd zijn of om andere ecologische redenen. Dit wordt in de betreffende figuur kort aangegeven.

Als gevolg van de optelling van meerdere soorten kán de bedekking meer zijn dan 100 procent, met name als er veel verdringingssoorten zijn geïdentificeerd. Dat is niet wat op een concrete locatie gebeurt, maar de gebruikte methode laat het niet toe om hiervoor te corrigeren. De responscurven moeten dus als maximale bedekking door verdringingssoorten worden beschouwd.

De beoordeling van de plausibiliteit van de curven wordt opnieuw aangegeven met gekleurde bolletjes: groen voor goed, geel voor matig en rood voor slecht.

Omdat alleen soorten zijn geselecteerd die toenemen in bedekking met minimaal ongeveer 10 procentpunt, neemt per definitie ook de resulterende responscurve voor de habitattypen toe in bedekking. Voor de meeste soorten neemt de bedekking al toe voordat de KDW wordt bereikt. Dat hoeft op zich niet in tegenspraak te zijn met de KDW: een toename van een verdringingssoort hoeft nog niet te betekenen dat de kwaliteit afneemt op een wijze die voor de KDW-bepaling relevant is. Voor een aantal typen is er echter sprake van een grote stijging onder de KDW. Dit is niet volgens verwachting. Immers, als de toename van verdringingssoorten al groot is bij deposities lager dan de KDW, zou de KDW eigenlijk lager moeten liggen. Voor veel soorten en ook habitattypen neemt de bedekking ook toe voorbij de KDW en de empirische KDW en wordt daar de grootste stijging bereikt. Dit is conform de verwachting.

Het aantal soorten dat gezamenlijk tot verdringing leidt, is per type nogal verschillend. Het aantal is klein in bijvoorbeeld Vochtige heiden (hogere zandgronden, 4010-A), waarbij vooral Molinea caerulea (Pijpenstrootje) een grote toename laat zien en in mindere mate drie andere soorten. Het aantal is duidelijk groter in bij voorbeeld Stroomdalgraslanden (6120): de tien verdringingssoorten laten ieder een ongeveer even grote stijging in bedekking zien (wat overigens wel van locatie tot locatie kan verschillen). 
1310-A (ZOU)

Zilte pionierbegroeiingen (zeekraal)

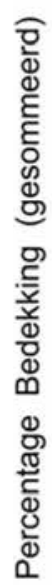

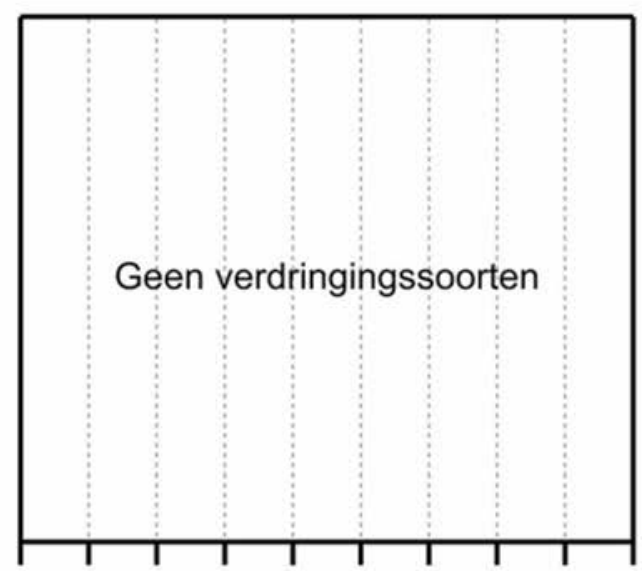

$\begin{array}{llllllllll}0 & 10 & 20 & 30 & 40 & 50 & 60 & 70 & 80 & 90\end{array}$

1320 (ZOU)

Slijkgrasvelden

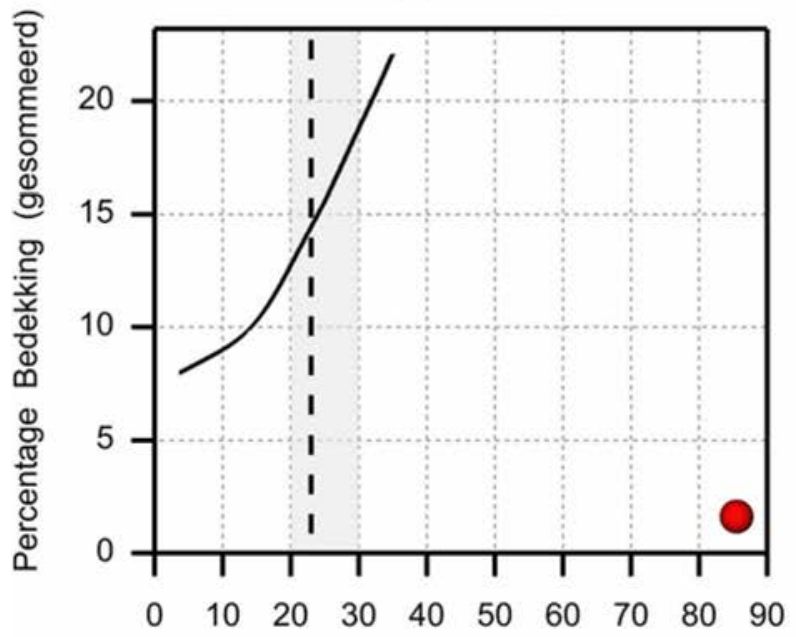

1330-B (ZOU)

Schorren en zilte graslanden (binnendijks)

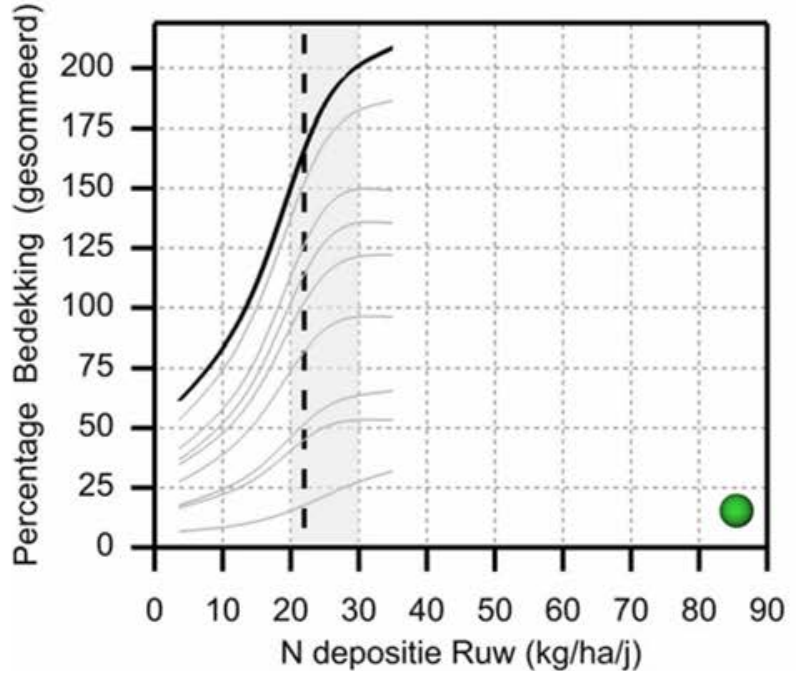

1310-B (ZOU)

Zilte pionierbegroeiingen (zeevetmuur)

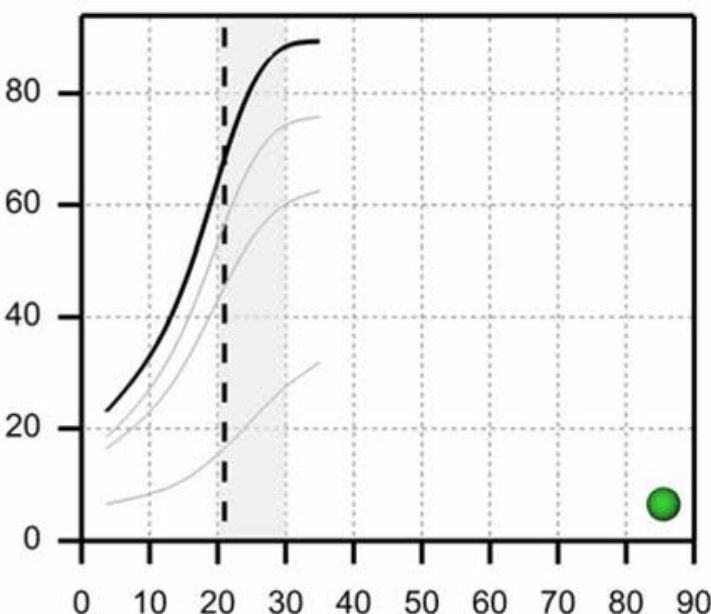

1330-A (ZOU)

Schorren en zilte graslanden (buitendijks)

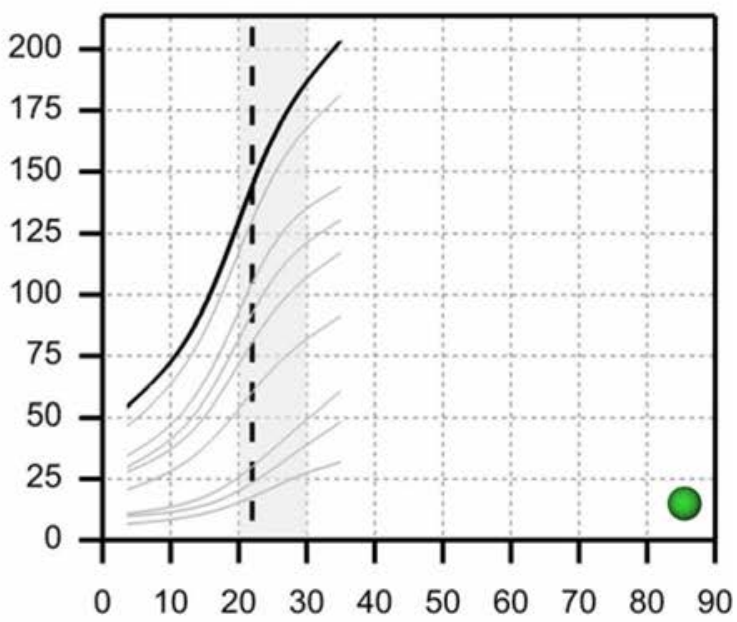

2120 (D-G)

Witte duinen

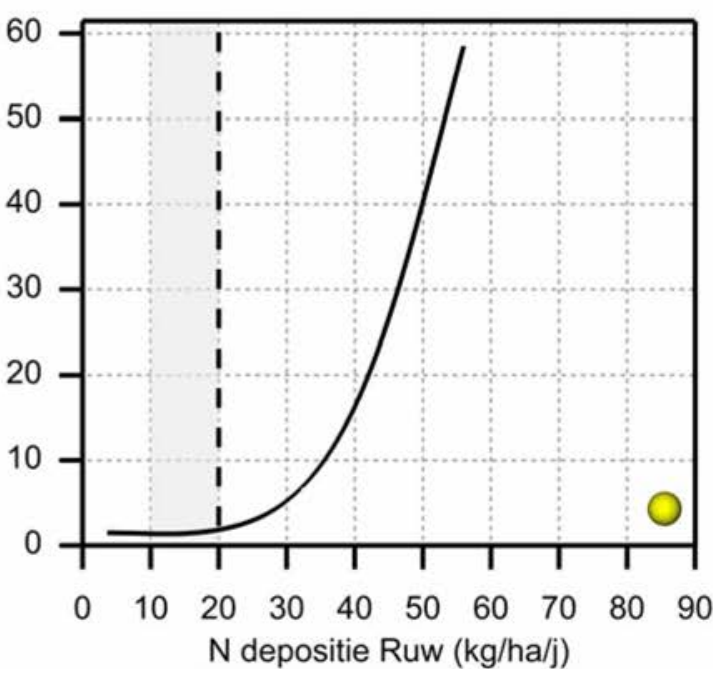

Figuur 51 Gestapelde responscurven (grijs) voor stikstofdepositie van verdringingssoorten per habitattype met in het zwart de gesommeerde curve voor het habitattype. De verticale gestippelde lijn geeft de KDW (Van Dobben et al., 2012), het grijze vak de range van de empirische kritische depositiewaarde (Bobbink \& Hettelingh, 2011). In de kop van elke figuur wordt tussen haken het structuurtype gegeven (voor de afkortingen zie Tabel 2). Voor sommige typen wordt geen responscurve gegeven, in de figuur staat kort waarom. De kleurcodering geeft de expertbeoordeling van de curve als in Tabel 12 (groen=goed, geel=matig, rood=slecht). 
$2130-A(D-G)$

Grijze duinen (kalkrijk)
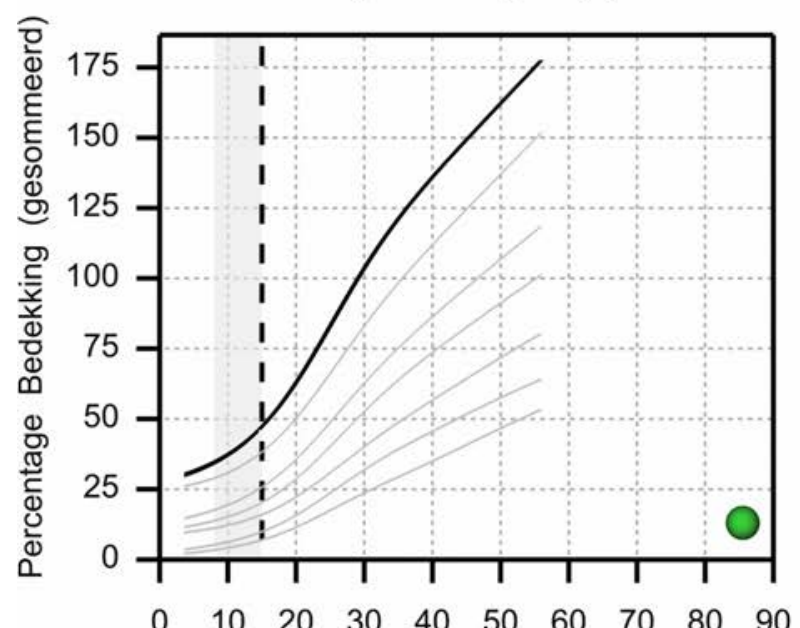

2130-C (D-G)

Grijze duinen (heischraal)

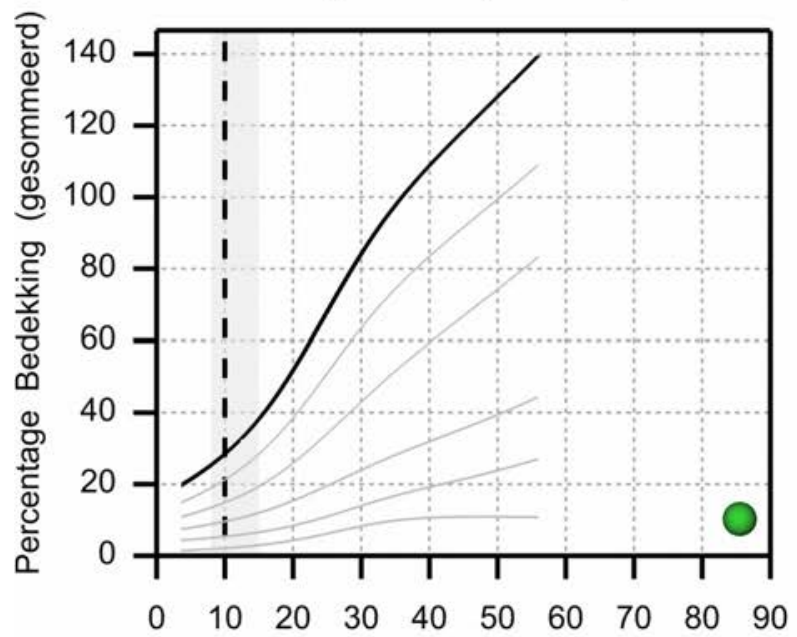

2140-B (D-DS)

Duinheiden met kraaihei (droog)

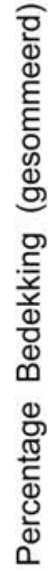

Geen verdringsssoorten

met voldoende presenties

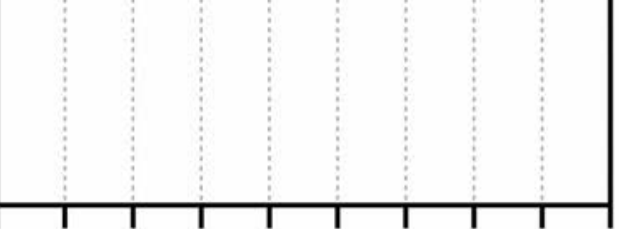

$\begin{array}{llllllllll}0 & 10 & 20 & 30 & 40 & 50 & 60 & 70 & 80 & 90\end{array}$

$\mathrm{N}$ depositie Ruw $(\mathrm{kg} / \mathrm{ha} / \mathrm{j})$
2130-B (D-G)

Grijze duinen (kalkarm)

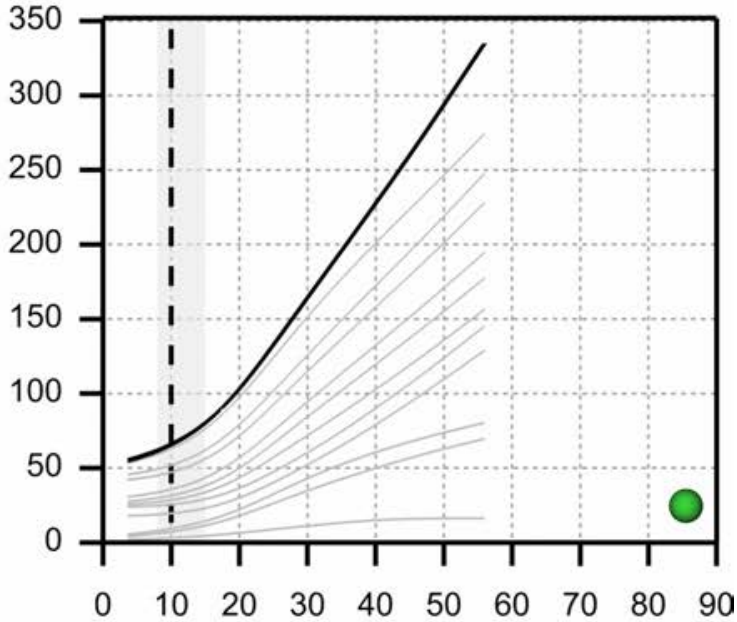

2140-A (N-DS)

Duinheiden met kraaihei (vochtig)

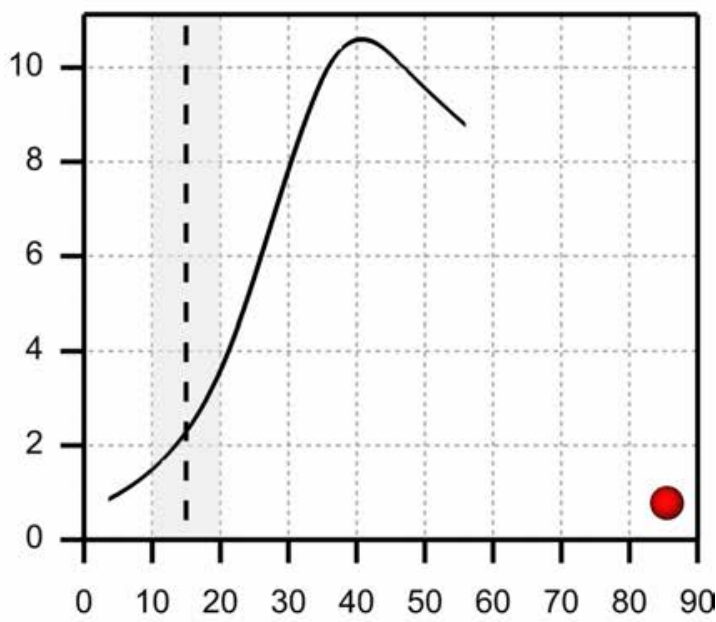

2150 (D-DS)

Duinheiden met struikhei

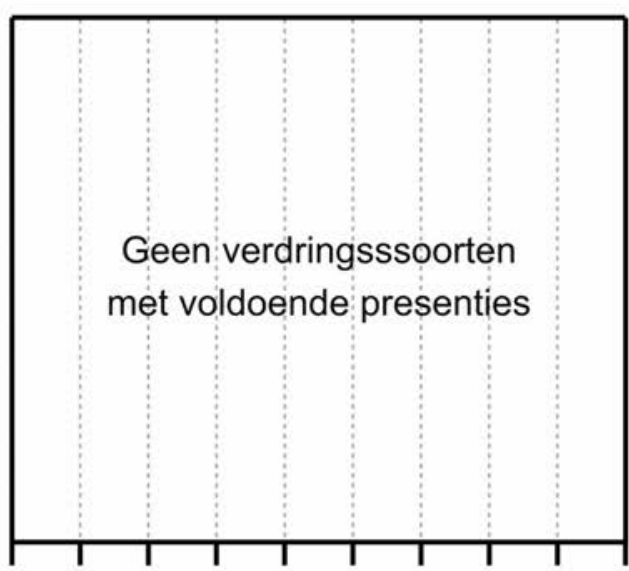

$\begin{array}{llllllllll}0 & 10 & 20 & 30 & 40 & 50 & 60 & 70 & 80 & 90\end{array}$

$\mathrm{N}$ depositie Ruw (kg/ha/j)

Figuur 52 Gestapelde responscurven (grijs) voor stikstofdepositie van verdringingssoorten per habitattype met in het zwart de gesommeerde curve voor het habitattype. De verticale gestippelde lijn geeft de KDW (Van Dobben et al., 2012), het grijze vak de range van de empirische kritische depositiewaarde (Bobbink \& Hettelingh, 2011). In de kop van elke figuur wordt tussen haken het structuurtype gegeven (voor de afkortingen zie Tabel 2). Voor sommige typen wordt geen responscurve gegeven, in de figuur staat kort waarom. De kleurcodering geeft de expertbeoordeling van de curve als in Tabel 12 (groen=goed, geel=matig, rood=slecht). 
2160 (D-S)

Duindoornstruwelen
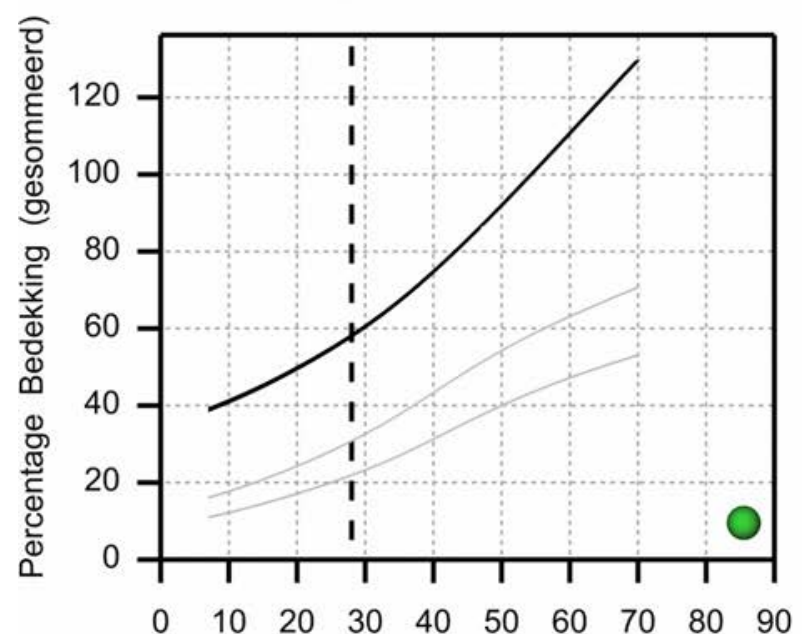

2180-A (D-B)

Duinbossen (droog)

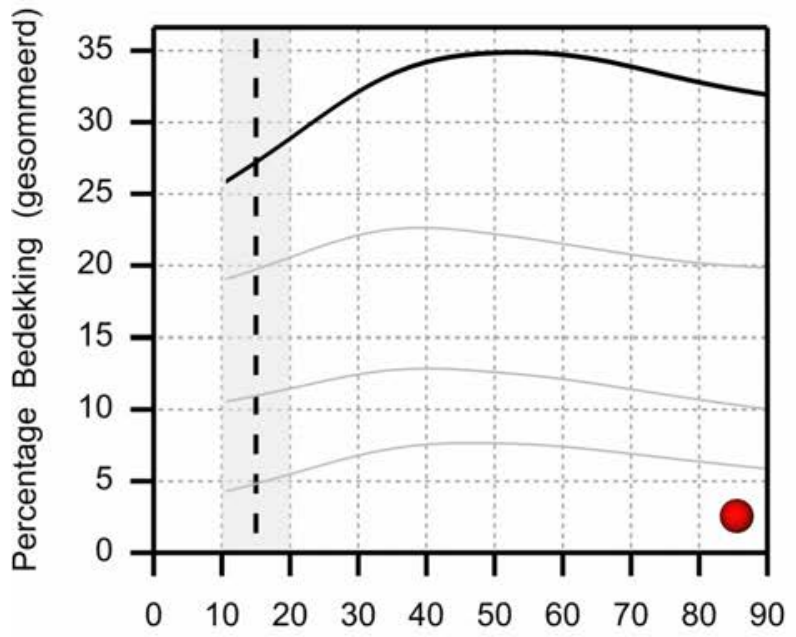

2180-C (D-B)

Duinbossen (binnenduinrand)

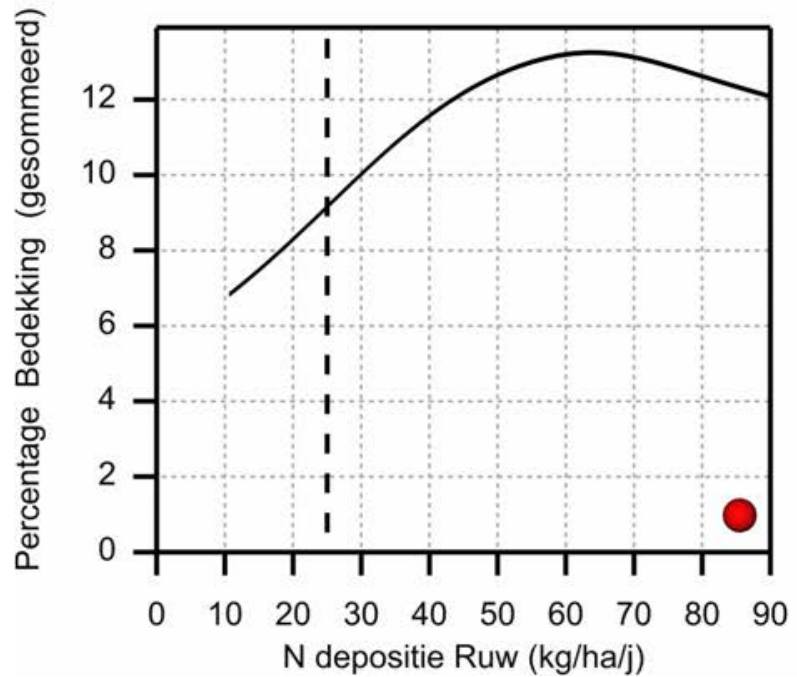

2170 (N-DS)

Kruipwilgstruwelen
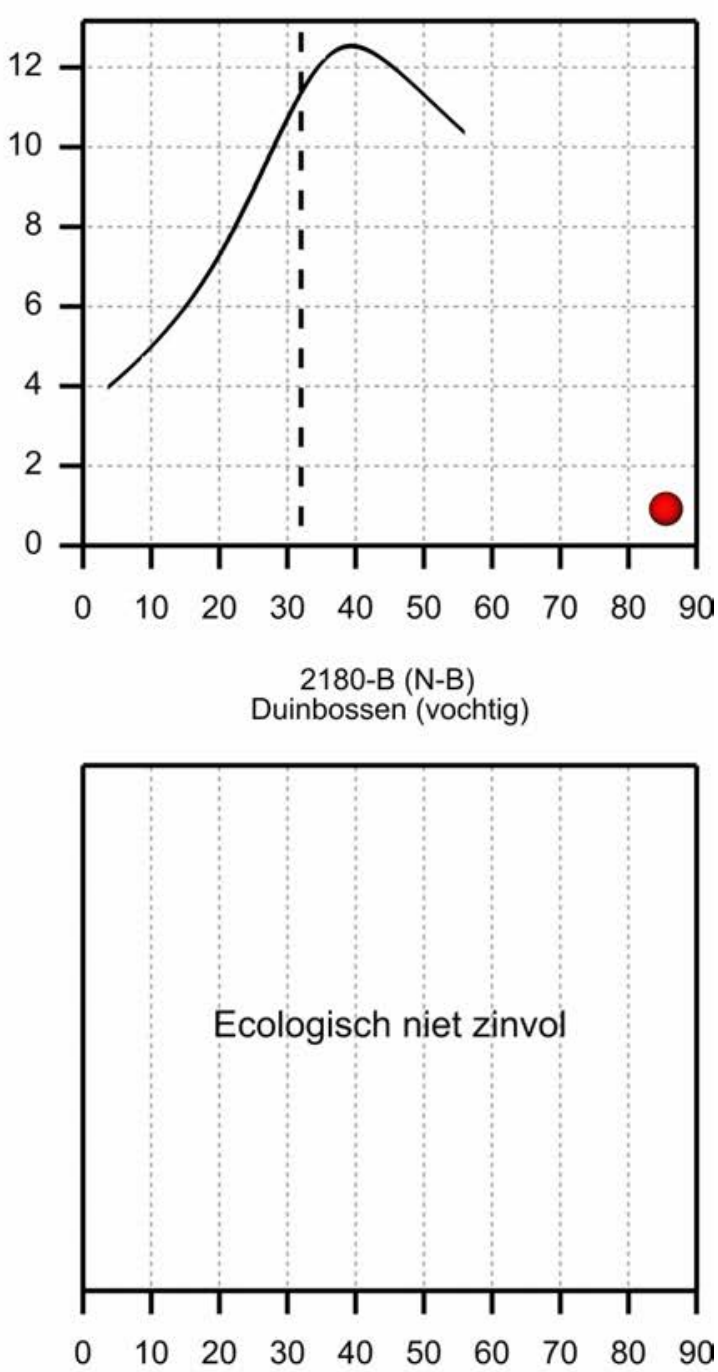

2190-A (WAT)

Vochtige duinvalleien (open water)

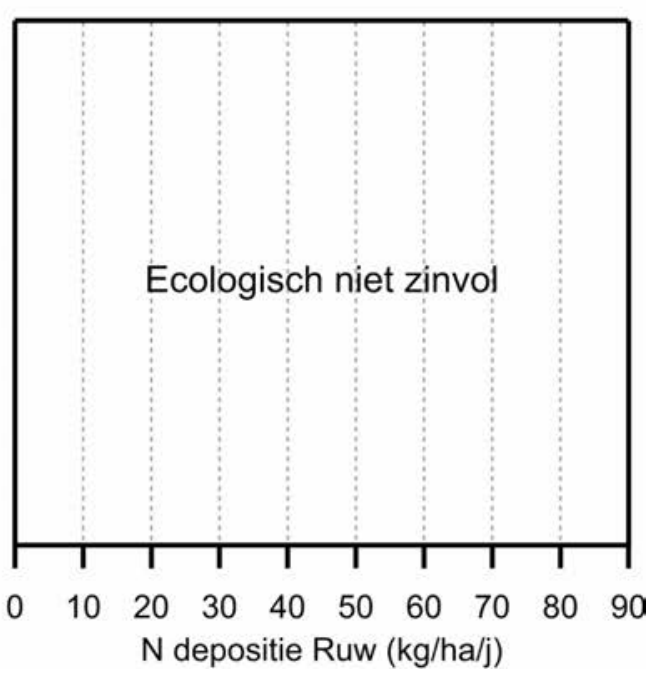

Figuur 53 Gestapelde responscurven (grijs) voor stikstofdepositie van verdringingssoorten per habitattype met in het zwart de gesommeerde curve voor het habitattype. De verticale gestippelde lijn geeft de KDW (Van Dobben et al., 2012), het grijze vak de range van de empirische kritische depositiewaarde (Bobbink \& Hettelingh, 2011). In de kop van elke figuur wordt tussen haken het structuurtype gegeven (voor de afkortingen zie Tabel 2). Voor sommige typen wordt geen responscurve gegeven, in de figuur staat kort waarom. De kleurcodering geeft de expertbeoordeling van de curve als in Tabel 12 (groen=goed, geel=matig, rood=slecht). 
$2190-B(N-G)$

Vochtige duinvalleien (kalkrijk)
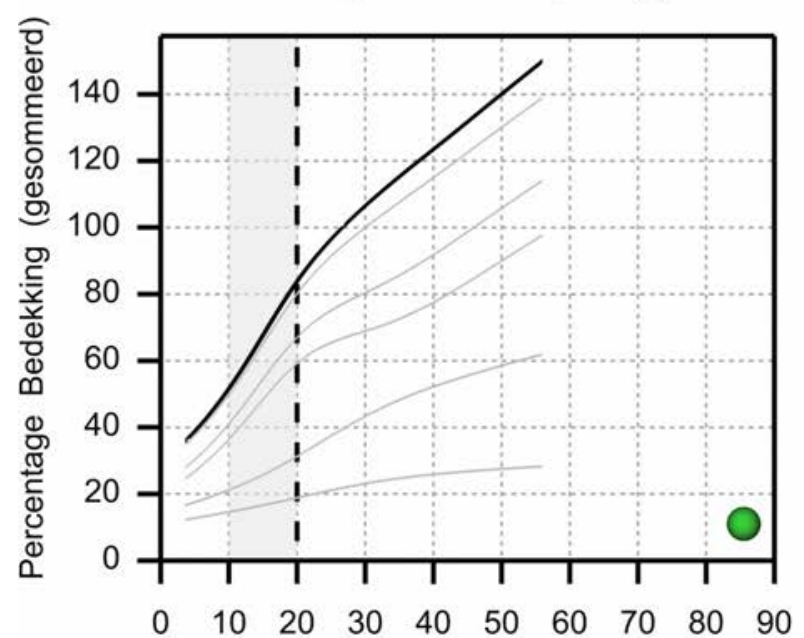

2310 (D-DS)

Stuifzandheiden met struikhei

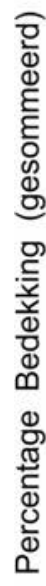

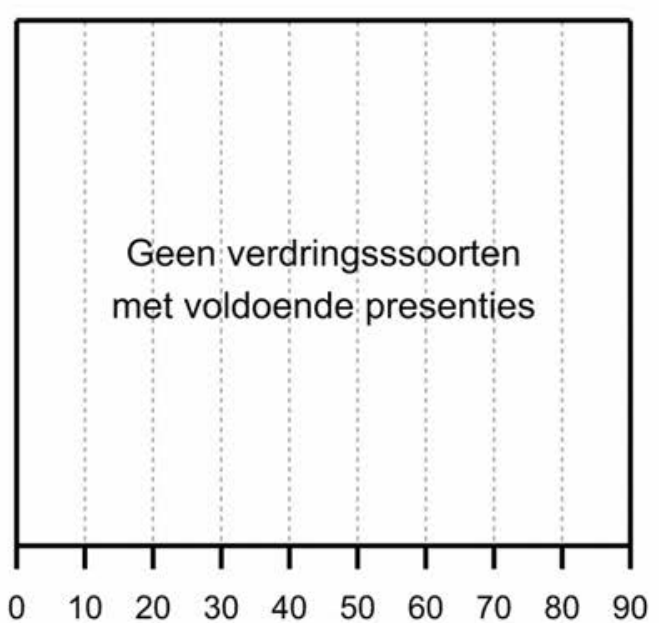

2330 (D-G)

Zandverstuivingen

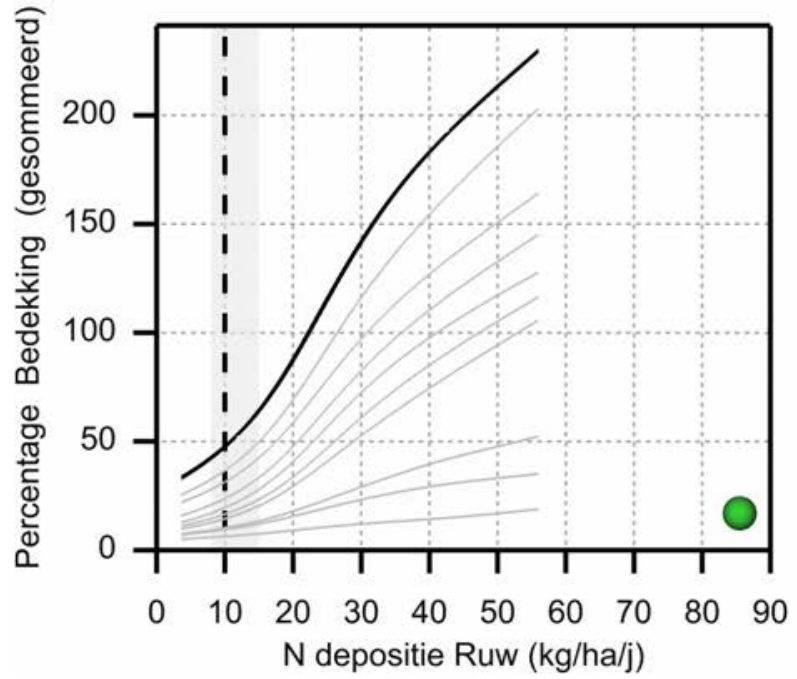

2190-C (N-G)

Vochtige duinvalleien (ontkalkt)
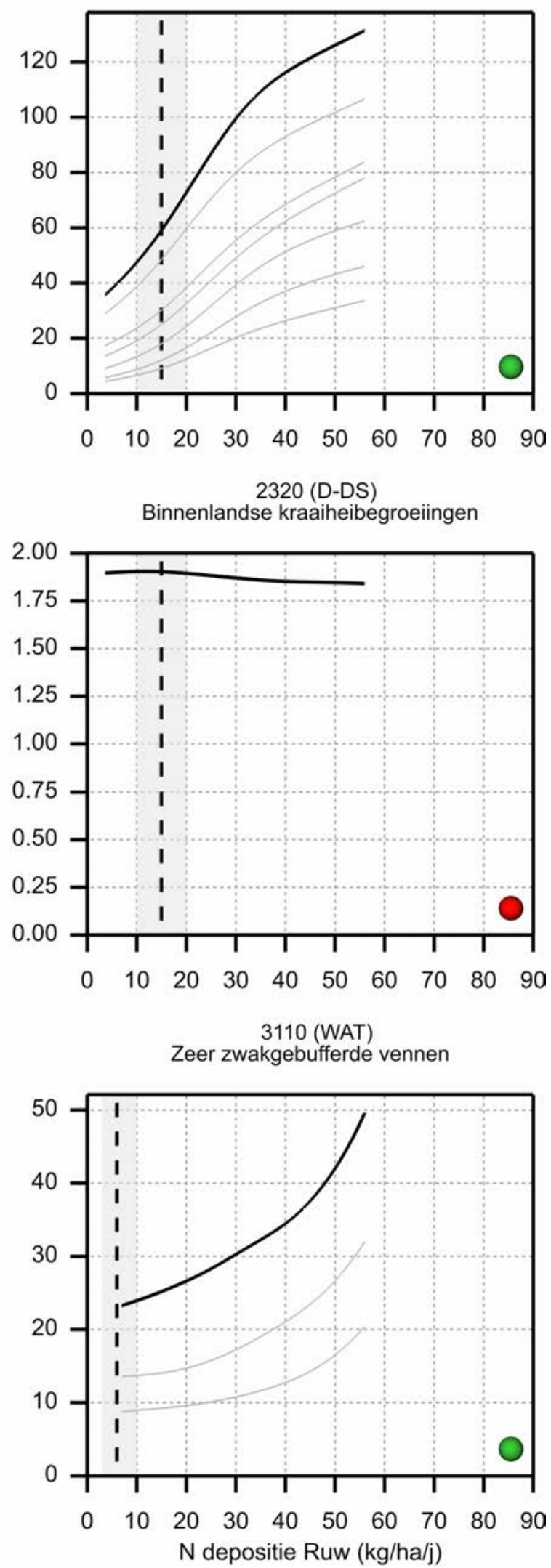

Figuur 54 Gestapelde responscurven (grijs) voor stikstofdepositie van verdringingssoorten per habitattype met in het zwart de gesommeerde curve voor het habitattype. De verticale gestippelde lijn geeft de KDW (Van Dobben et al., 2012), het grijze vak de range van de empirische kritische depositiewaarde (Bobbink \& Hettelingh, 2011). In de kop van elke figuur wordt tussen haken het structuurtype gegeven (voor de afkortingen zie Tabel 2). Voor sommige typen wordt geen responscurve gegeven, in de figuur staat kort waarom. De kleurcodering geeft de expertbeoordeling van de curve als in Tabel 12 (groen=goed, geel=matig, rood=slecht). 

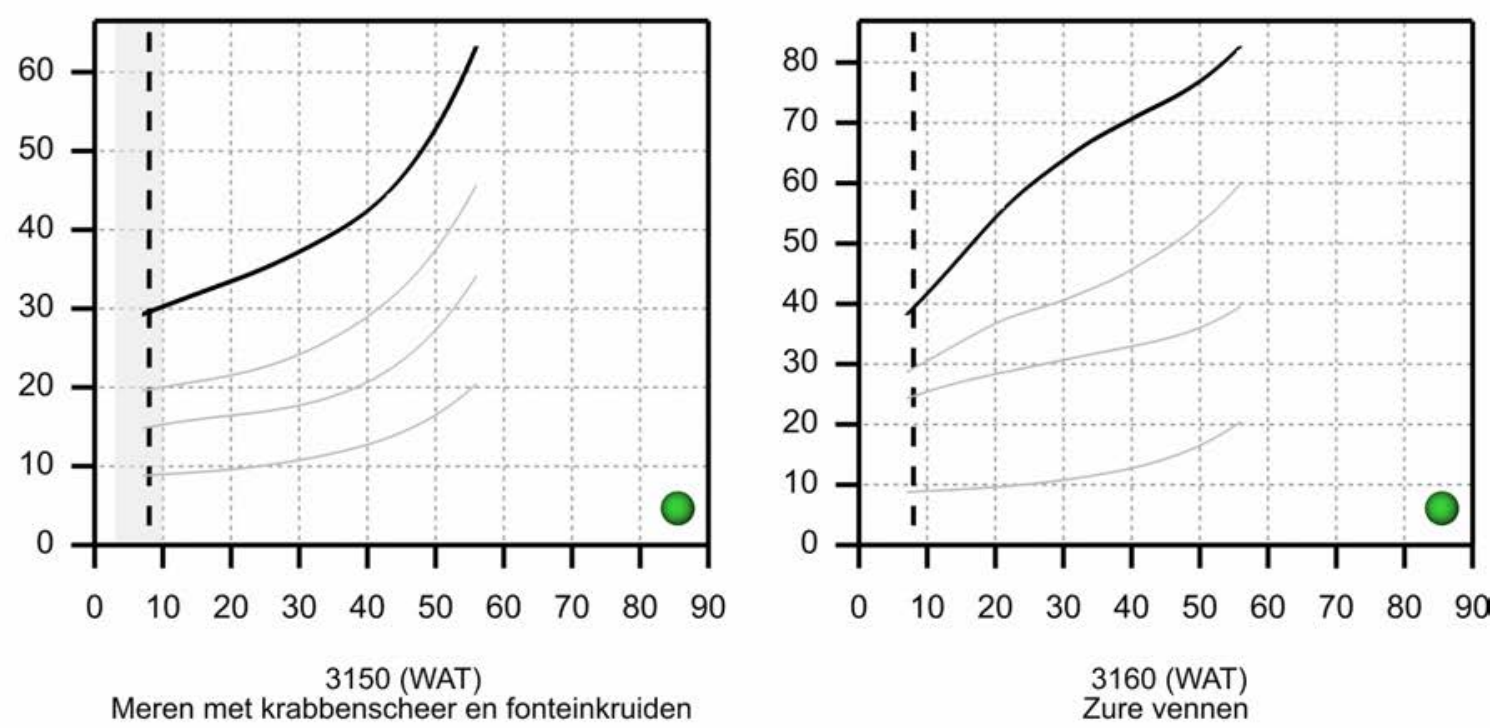

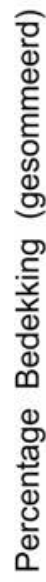

3150 (WAT)

Meren met krabbenscheer en fonteinkruiden

Zure vennen
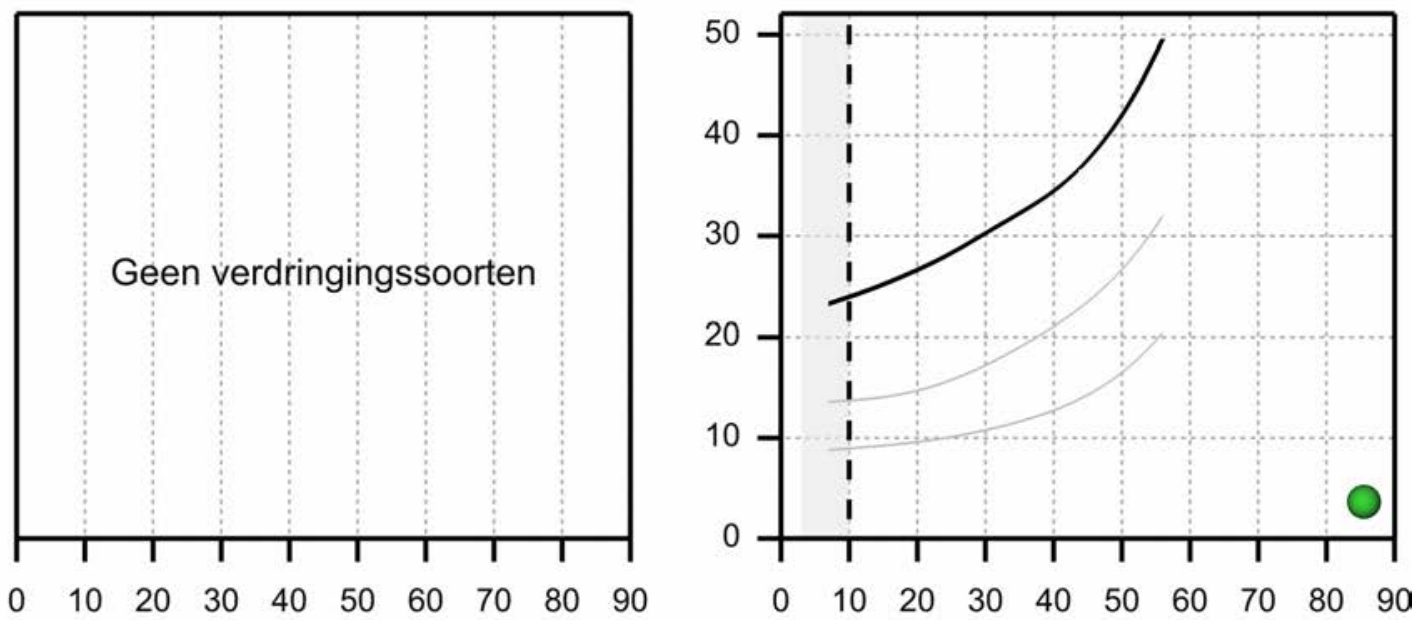

4010-A (N-DS)

Vochtige heiden (hogere zandgronden)

4010-B (N-DS)

Vochtige heiden (laagveengebied)
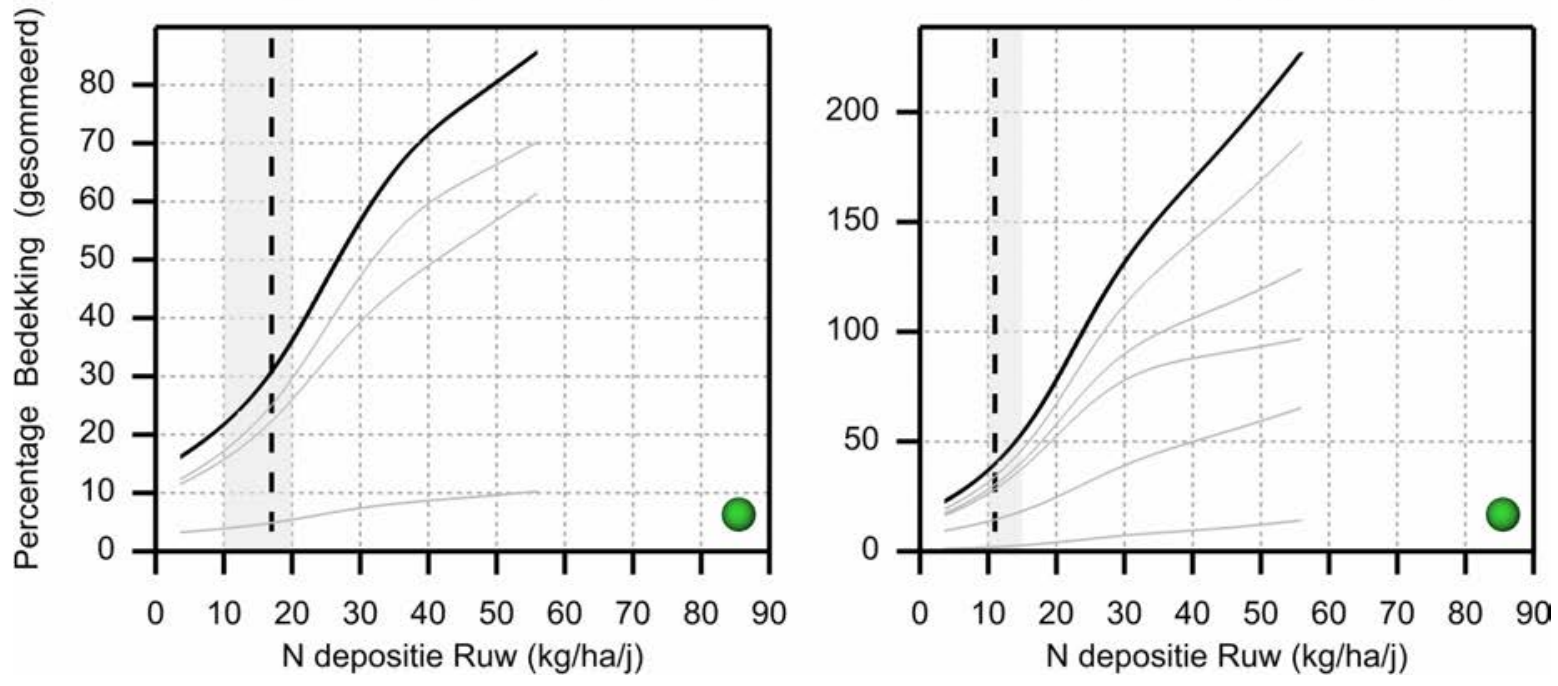

Figuur 55 Gestapelde responscurven (grijs) voor stikstofdepositie van verdringingssoorten per habitattype met in het zwart de gesommeerde curve voor het habitattype. De verticale gestippelde lijn geeft de KDW (Van Dobben et al., 2012), het grijze vak de range van de empirische kritische depositiewaarde (Bobbink \& Hettelingh, 2011). In de kop van elke figuur wordt tussen haken het structuurtype gegeven (voor de afkortingen zie Tabel 2). Voor sommige typen wordt geen responscurve gegeven, in de figuur staat kort waarom. De kleurcodering geeft de expertbeoordeling van de curve als in Tabel 12 (groen=goed, geel=matig, rood=slecht). 


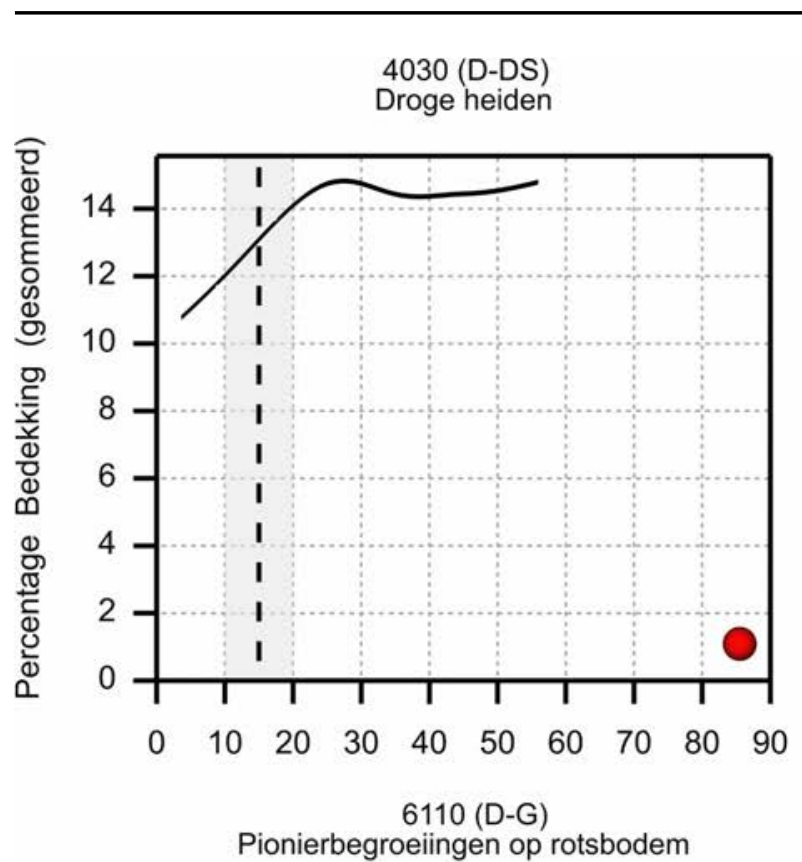

5130 (D-S)

Jeneverbesstruwelen
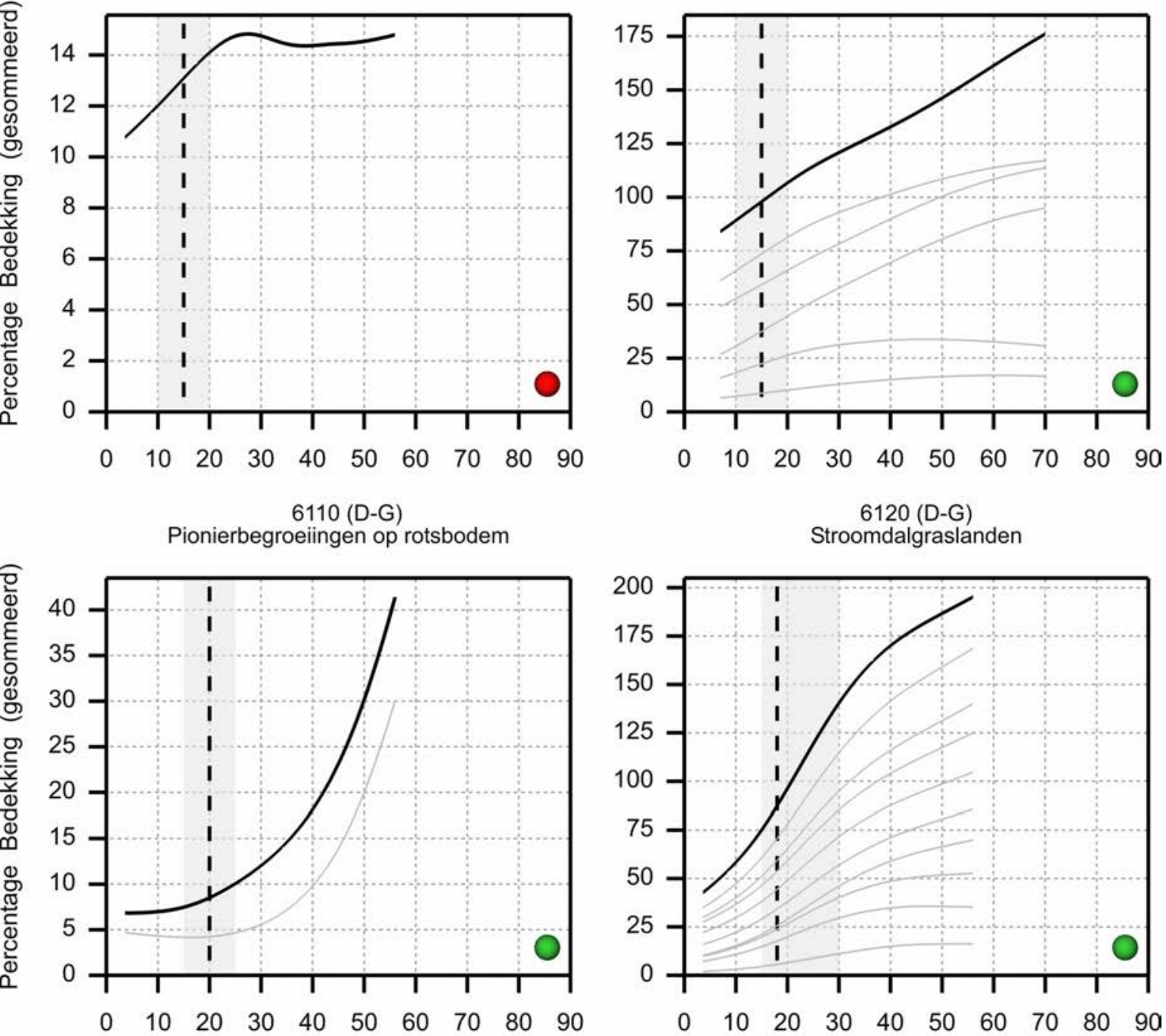

6130 (D-G)

Zinkweiden

6210 (D-G)

Kalkgraslanden
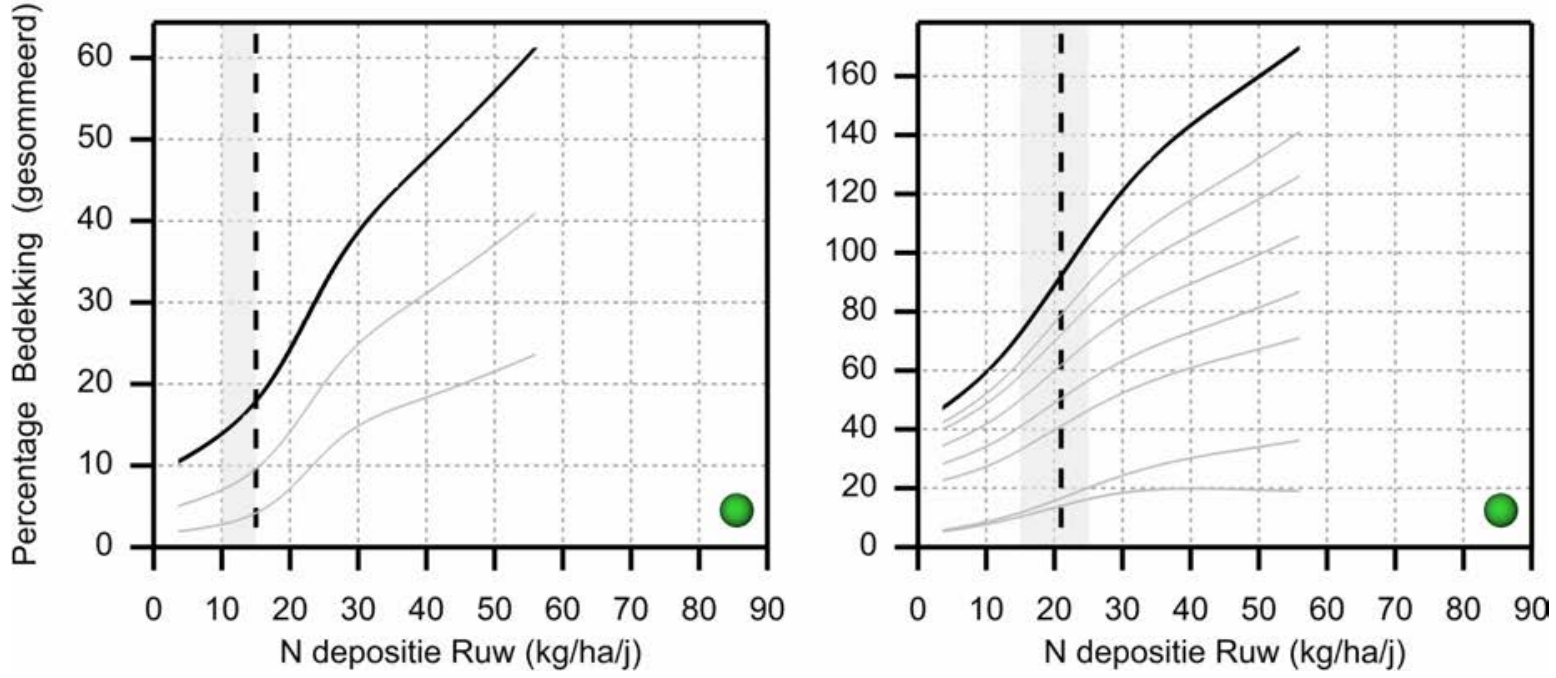

Figuur 56 Gestapelde responscurven (grijs) voor stikstofdepositie van verdringingssoorten per habitattype met in het zwart de gesommeerde curve voor het habitattype. De verticale gestippelde lijn geeft de KDW (Van Dobben et al., 2012), het grijze vak de range van de empirische kritische depositiewaarde (Bobbink \& Hettelingh, 2011). In de kop van elke figuur wordt tussen haken het structuurtype gegeven (voor de afkortingen zie Tabel 2). Voor sommige typen wordt geen responscurve gegeven, in de figuur staat kort waarom. De kleurcodering geeft de expertbeoordeling van de curve als in Tabel 12 (groen=goed, geel=matig, rood=slecht). 
6230 (D-G)

Heischrale graslanden

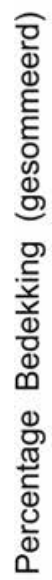

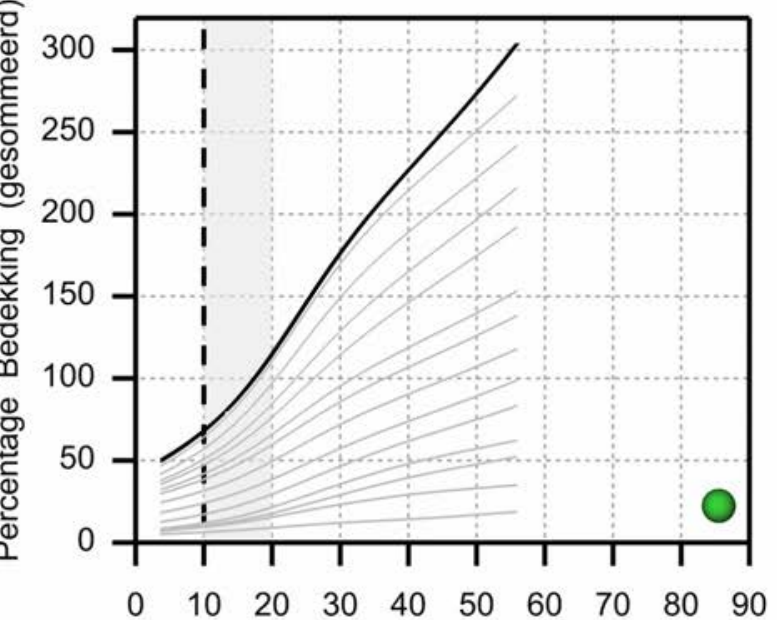

6430-C (D-B)

Ruigten en zomen (droge bosranden)

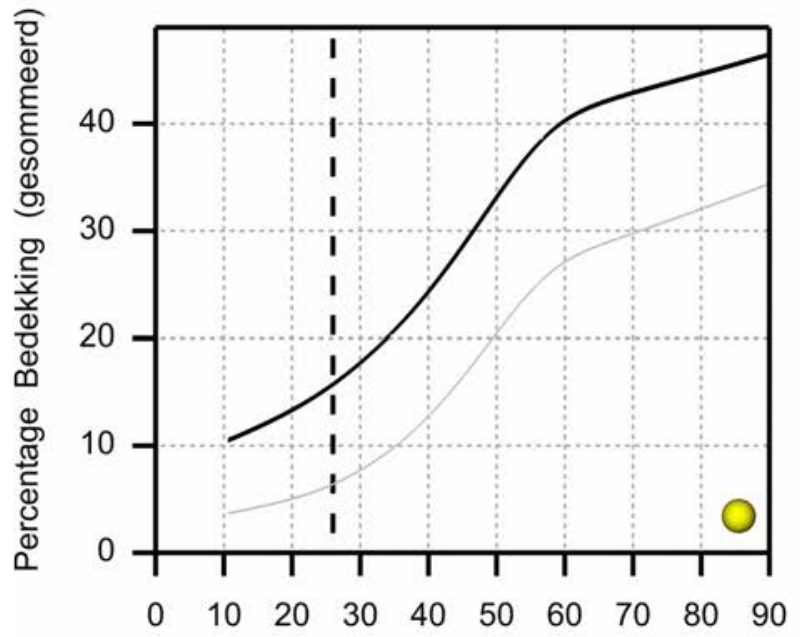

6510-B (D-G)

Glanshaver/vossenstaart hooiland (grote vossenstaart)
$6410(\mathrm{~N}-\mathrm{G})$

Blauwgraslanden

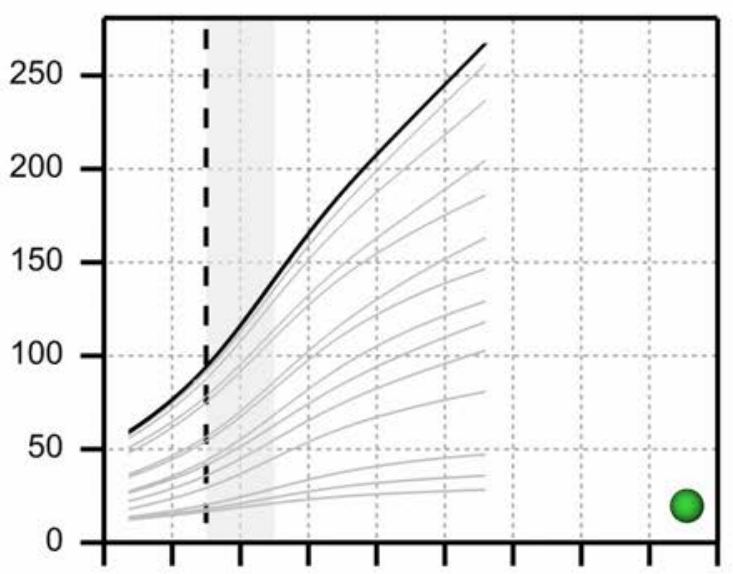

$\begin{array}{llllllllll}0 & 10 & 20 & 30 & 40 & 50 & 60 & 70 & 80 & 90\end{array}$

6510-A (D-G)

Glanshaver/vossenstaart hooiland (glanshaver)

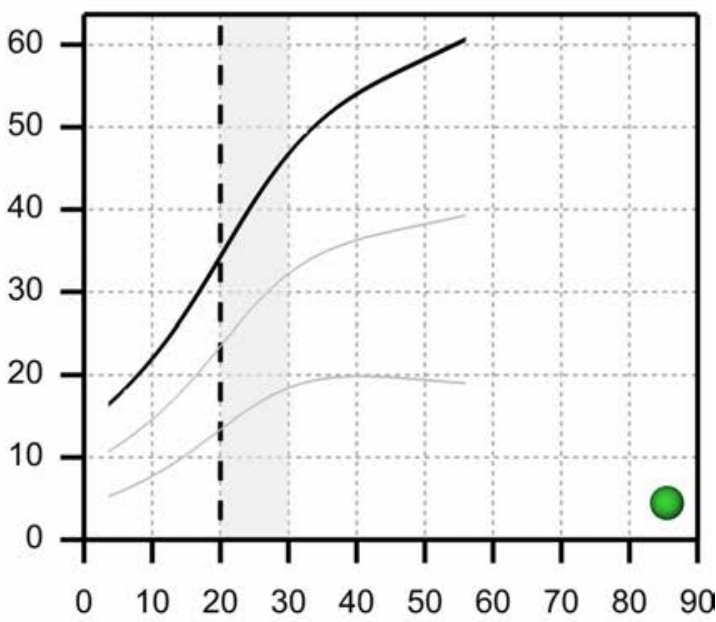

7110-A (N-DS/MOE)

Actieve hoogvenen (hoogveenlandschap)

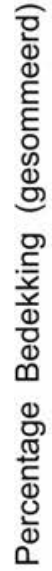
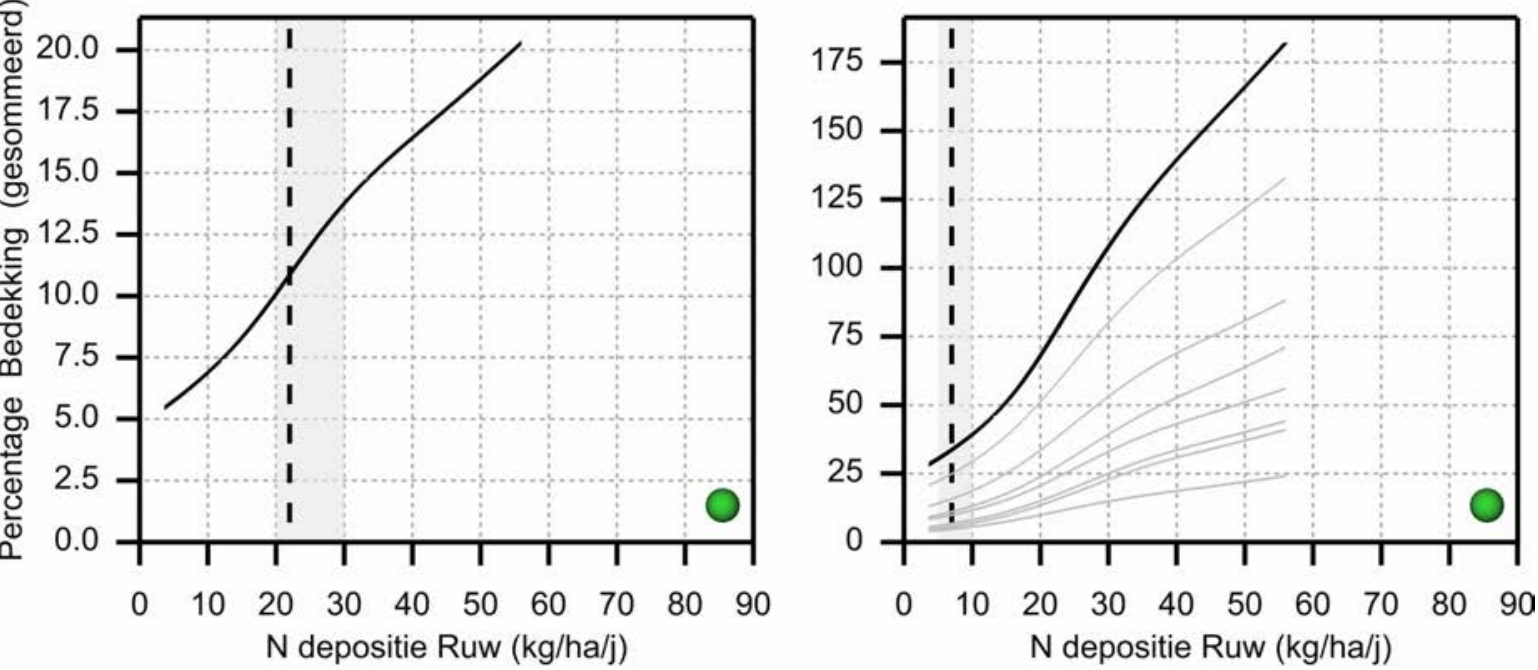

Figuur 57 Gestapelde responscurven (grijs) voor stikstofdepositie van verdringingssoorten per habitattype met in het zwart de gesommeerde curve voor het habitattype. De verticale gestippelde lijn geeft de KDW (Van Dobben et al., 2012), het grijze vak de range van de empirische kritische depositiewaarde (Bobbink \& Hettelingh, 2011). In de kop van elke figuur wordt tussen haken het structuurtype gegeven (voor de afkortingen zie Tabel 2). Voor sommige typen wordt geen responscurve gegeven, in de figuur staat kort waarom. De kleurcodering geeft de expertbeoordeling van de curve als in Tabel 12 (groen=goed, geel=matig, rood=slecht). 
7110-B (N-DS/MOE)

Actieve hoogvenen (heideveentjes)

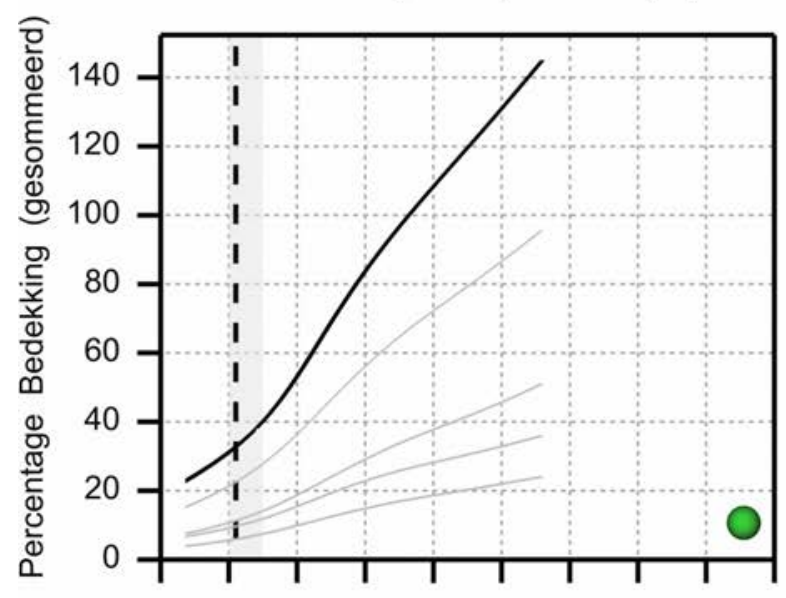

$7140-A(M O E)$

Overgangs- en trilvenen (trilvenen)

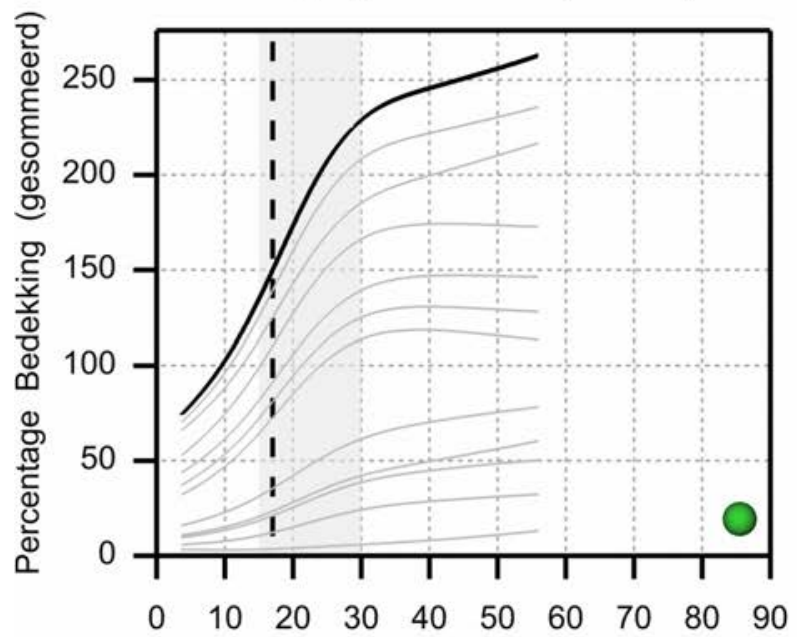

7150 (MOE)

Pioniervegetaties met snavelbiezen

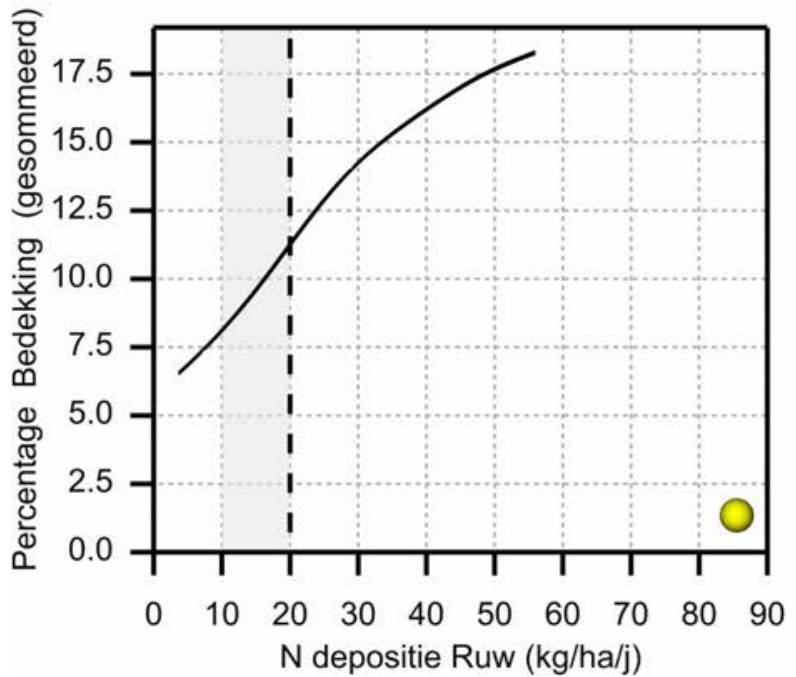

7120 (N-DS/MOE)

Herstellende hoogvenen

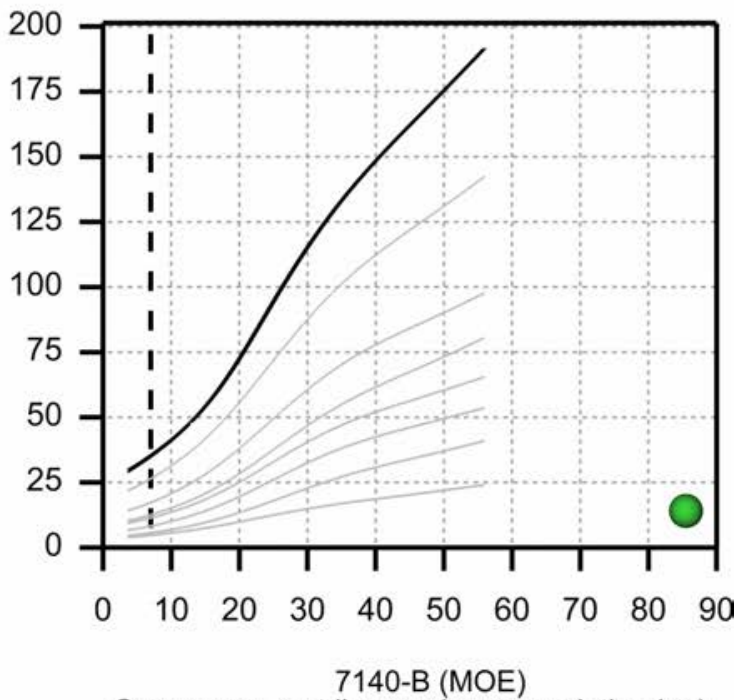

Overgangs- en trilvenen (veenmosrietlanden)
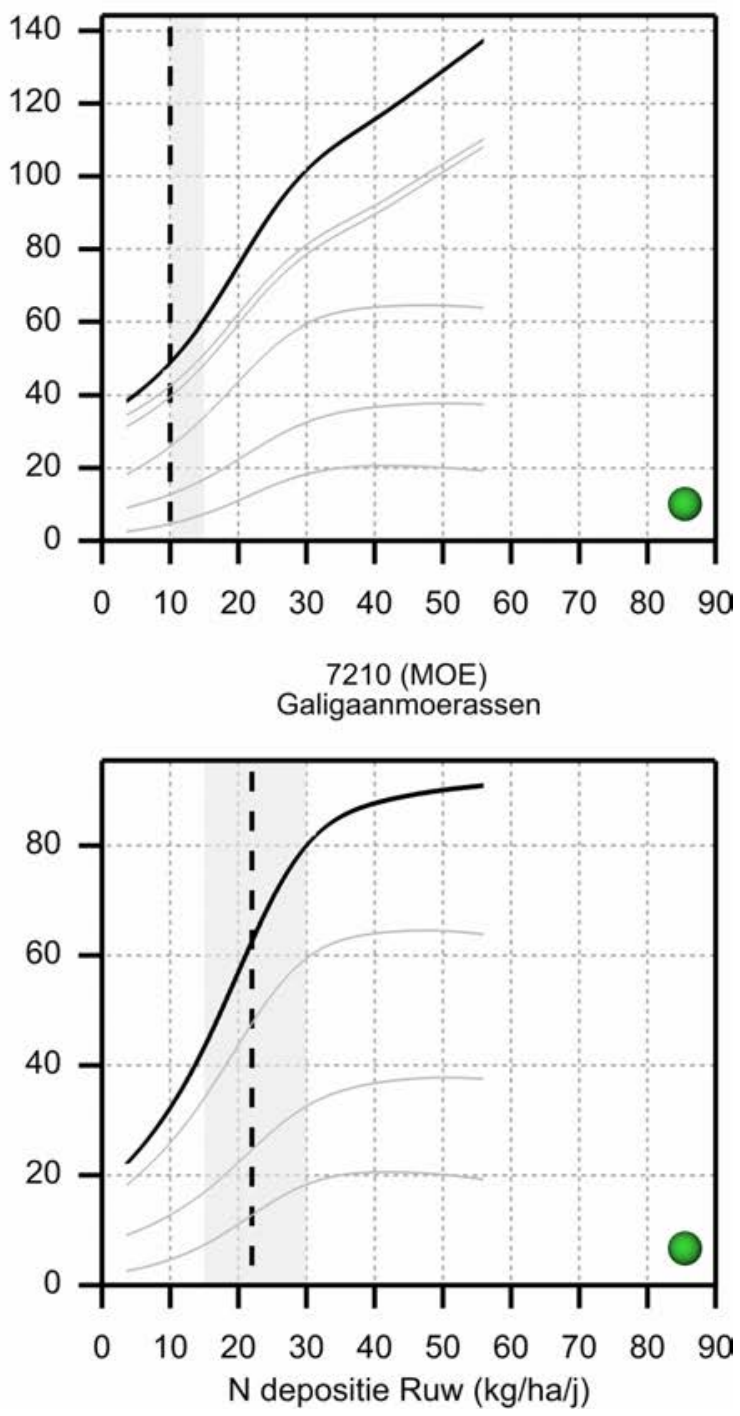

Figuur 58 Gestapelde responscurven (grijs) voor stikstofdepositie van verdringingssoorten per habitattype met in het zwart de gesommeerde curve voor het habitattype. De verticale gestippelde lijn geeft de KDW (Van Dobben et al., 2012), het grijze vak de range van de empirische kritische depositiewaarde (Bobbink \& Hettelingh, 2011). In de kop van elke figuur wordt tussen haken het structuurtype gegeven (voor de afkortingen zie Tabel 2). Voor sommige typen wordt geen responscurve gegeven, in de figuur staat kort waarom. De kleurcodering geeft de expertbeoordeling van de curve als in Tabel 12 (groen=goed, geel=matig, rood=slecht). 

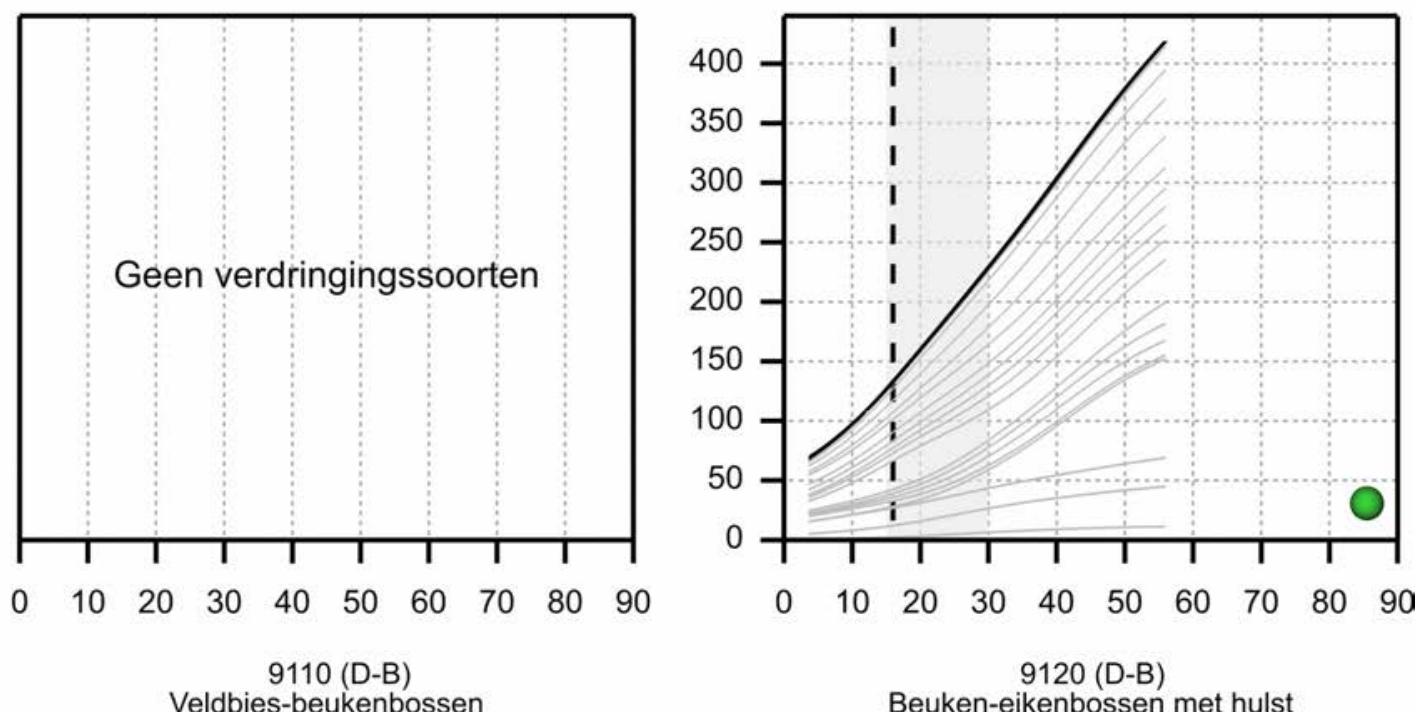

Veldbies-beukenbossen
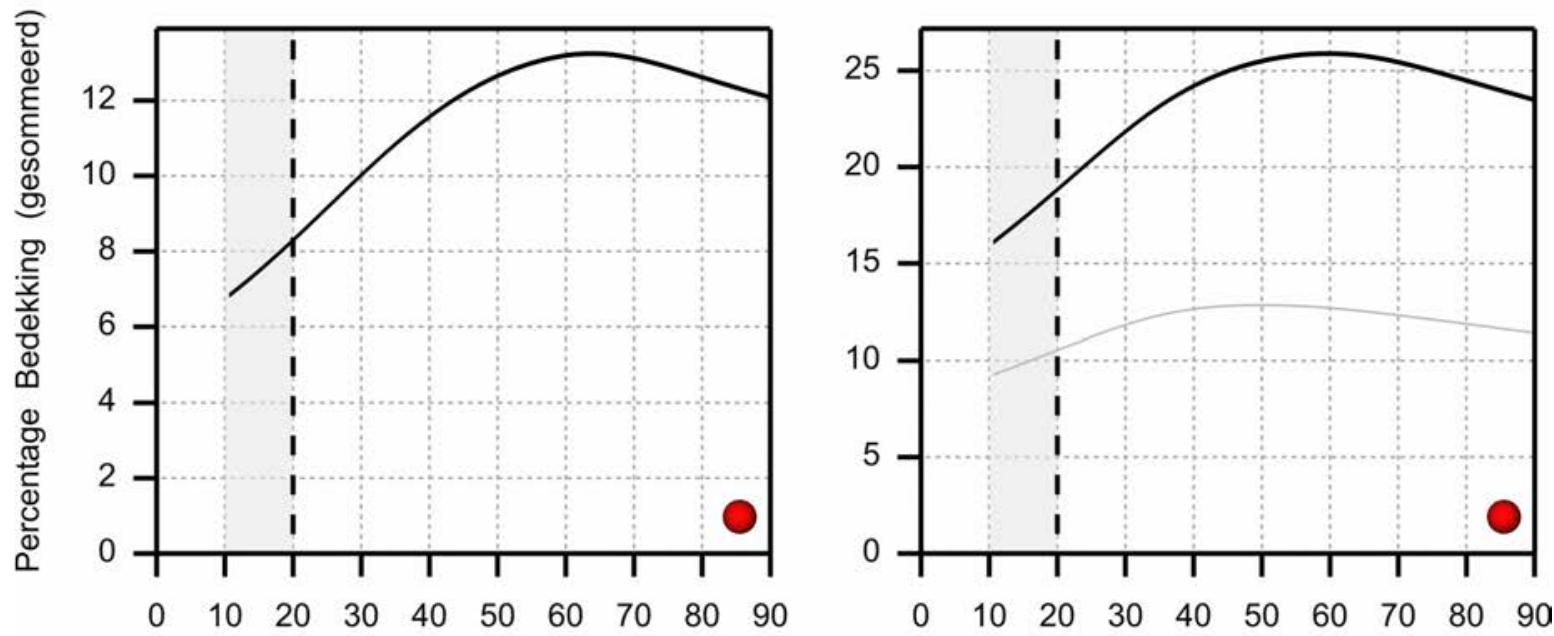

9160-A (N-B)

Eiken-haagbeukenbossen (hogere zandgronden)

9160-B (D-B)

Eiken-haagbeukenbossen (heuvelland)

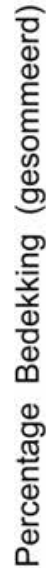
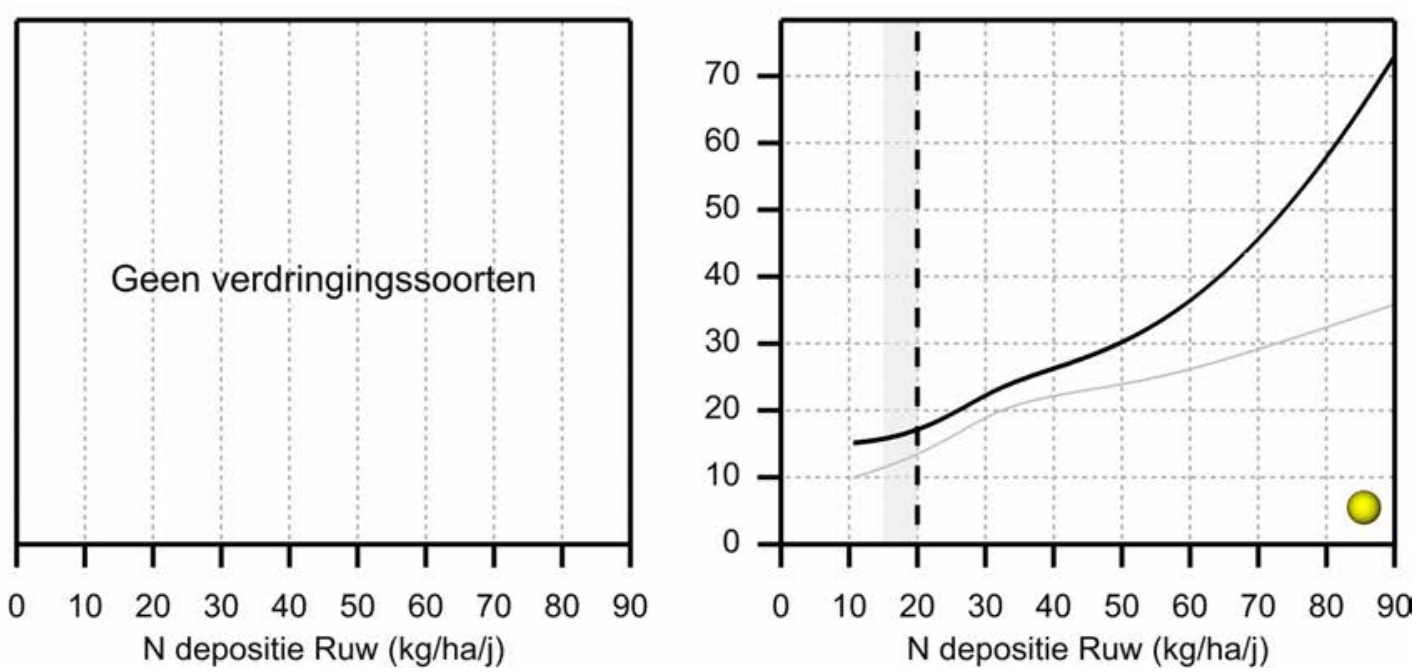

Figuur 59 Gestapelde responscurven (grijs) voor stikstofdepositie van verdringingssoorten per habitattype met in het zwart de gesommeerde curve voor het habitattype. De verticale gestippelde lijn geeft de KDW (Van Dobben et al., 2012), het grijze vak de range van de empirische kritische depositiewaarde (Bobbink \& Hettelingh, 2011). In de kop van elke figuur wordt tussen haken het structuurtype gegeven (voor de afkortingen zie Tabel 2). Voor sommige typen wordt geen responscurve gegeven, in de figuur staat kort waarom. De kleurcodering geeft de expertbeoordeling van de curve als in Tabel 12 (groen=goed, geel=matig, rood=slecht). 
9190 (D-B)

Oude eikenbossen

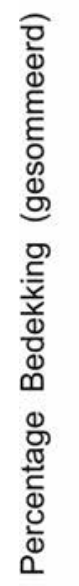

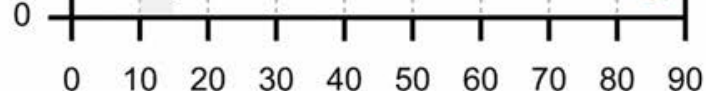

91E0-A (N-B)

Vochtige alluviale bossen (zachthoutooibossen)

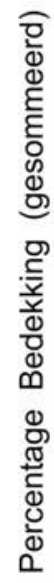

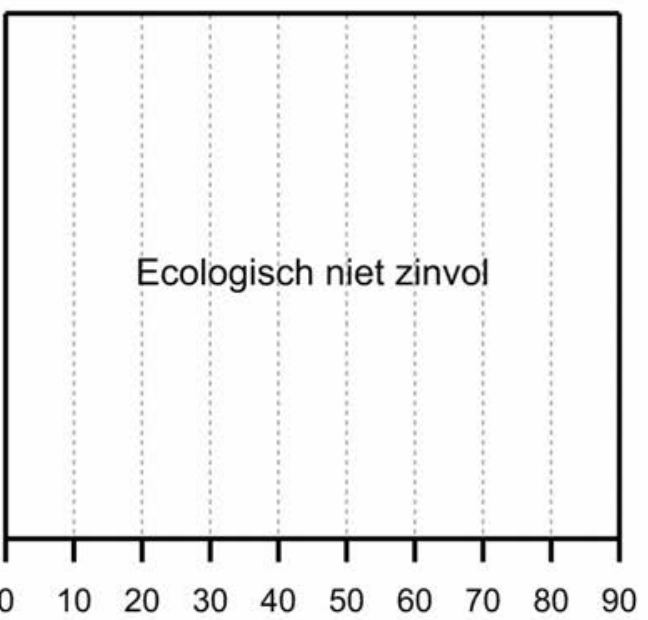

91E0-C (N-B)

Vochtige alluviale bossen (beekbegeleidende bossen)

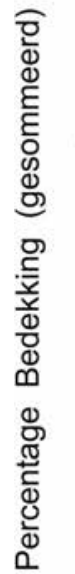

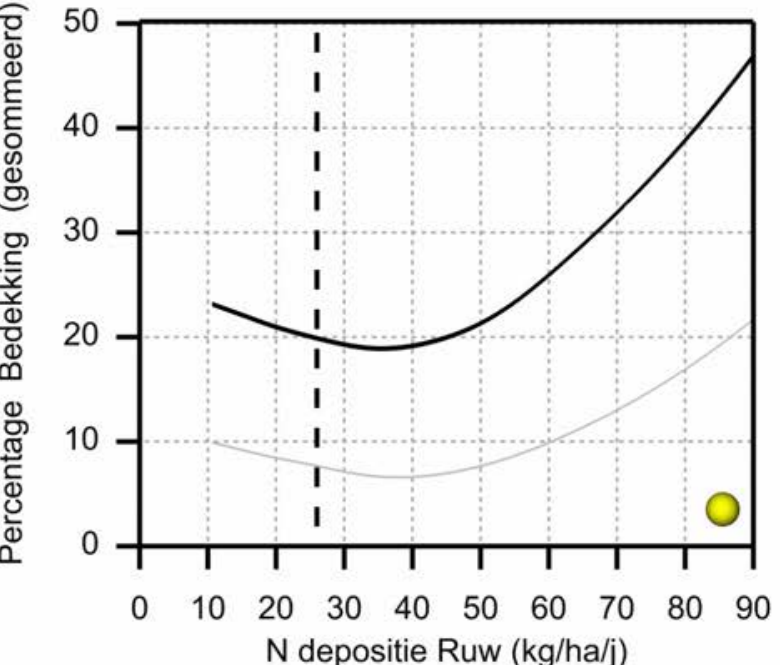

91D0 (N-B)

Hoogveenbossen

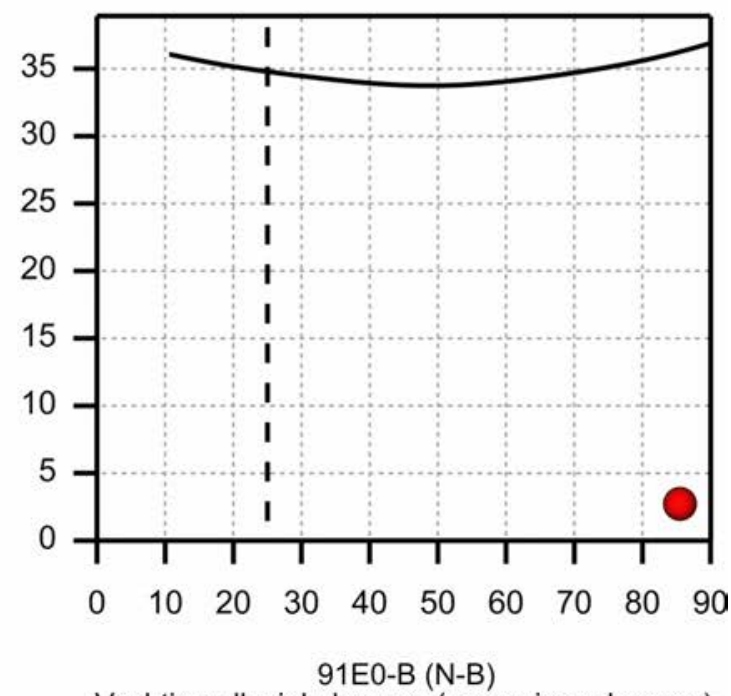

Vochtige alluviale bossen (essen-iepenbossen)
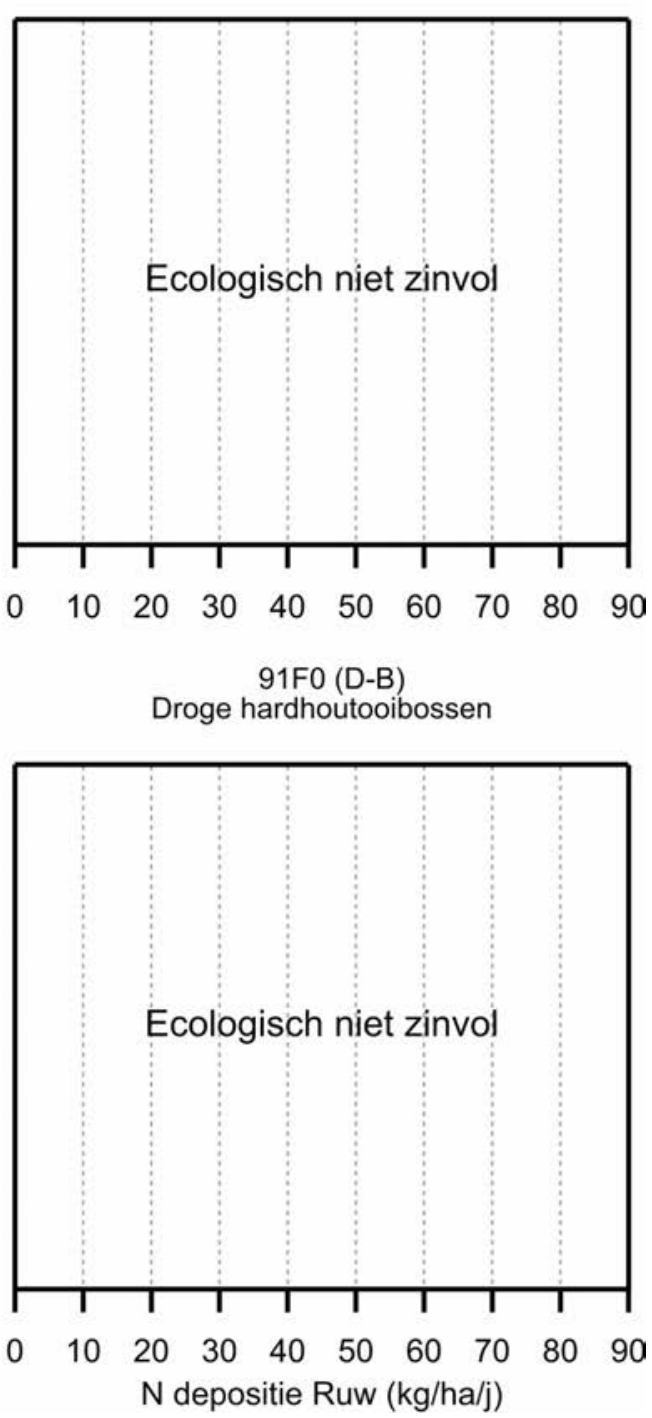

Figuur 60 Gestapelde responscurven (grijs) voor stikstofdepositie van verdringingssoorten per habitattype met in het zwart de gesommeerde curve voor het habitattype. De verticale gestippelde lijn geeft de KDW (Van Dobben et al., 2012), het grijze vak de range van de empirische kritische depositiewaarde (Bobbink \& Hettelingh, 2011). In de kop van elke figuur wordt tussen haken het structuurtype gegeven (voor de afkortingen zie Tabel 2). Voor sommige typen wordt geen responscurve gegeven, in de figuur staat kort waarom. De kleurcodering geeft de expertbeoordeling van de curve als in Tabel 12 (groen=goed, geel=matig, rood=slecht). 
In Tabel 12 zijn alle bedekkingen van verdringingssoorten voor habitattypen beoordeeld op hun plausibiliteit op basis van de vorm van de curve en de verhouding tot de KDW (expertinschatting). Uitgangspunt is dat een curve plausibel is als er een voortgaande toename in bedekking is voor de verdringingssoorten en dus ook voor de som daarvan per habitattype. Voor 55 van de 61 habitat(sub)typen zijn verdringingssoorten geselecteerd. Van die 55 habitat(sub)typen wordt de responscurve plausibel geacht voor 32 typen. Voor 5 typen is de curve als matig beoordeeld en voor 12 typen als slecht. Net als voor de kwalificerende soorten zijn er covariabelen die niet meegenomen konden worden, maar die wel invloed zouden kunnen uitoefenen op de responscurve. Daarnaast zijn de onverwachte curven reden voor nader onderzoek. 
1310-A Zilte pionierbegroeiingen (zeekraal) Geen verdringingssoorten.

1310-B Zilte pionierbegroeiingen Stijgende lijn. Duidelijke verdringingssoorten.

(zeevetmuur)

1320 Slijkgrasvelden

Slechts één soort, Spartina Anglica (Engels slijkgras) geselecteerd. Zijn de juiste soorten wel benoemd? Kwalificerende

verdringingsoort als enig soort voor type is niet correct.

1330-A Schorren en zilte graslanden (buitendijks)

1330-B Schorren en zilte graslanden

Stijgende lijn en flinke toename in bedekking.

(binnendijks)

$2110 \quad$ Embryonale duinen

2120 Witte duinen

Stijgende lijn en flinke toename van de bedekking. Drie soorten.

\section{0-A Grijze duinen (kalkrijk)}

2130-B Grijze duinen (kalkarm)

2130-C Grijze duinen (heischraal)

2140-A Duinheiden met kraaihei (vochtig)

Geen verdringingssoorten.

Stijgende lijn. De toename in bedekking is gering en wordt veroorzaakt door één soort, Leymus arenarius (Zandhaver). Een deel van

de respons is extrapolatie, dus de respons is minder groot dan hier wordt gegeven.

Sterke toename van de bedekking, na de KDW.

Sterke toename van de bedekking, na de KDW.

Sterke toename van de bedekking, na de KDW.

2140-B Duinheiden met kraaihei (droog) ontbreekt Molinia caerulea (Pijpenstrootje)?

2140-B Duinheiden met kraaihei (droog) Geen verdringingssoorten.

2150 Duinheide met struikhei Geen verdringingssoorten.

2160 Duindoornstruwelen Toenemende bedekking. Drie soorten.

$2170 \quad$ Kruipwilgstruwelen

2180-A Duinbossen (droog)

2180-B Duinbossen (vochtig)

2180-C Duinbossen (binnenduinrand)

2190-A Vochtige duinvalleien (open water)

2190-B Vochtige duinvalleien (kalkrijk)

Zeer kleine toename in bedekking gevolgd door een licht dalende curve. Eén soort, Holcus lanatus (Gestreepte witbol).

Eerst lichte stijging daarna kleine daling.

Bostype, ecologisch niet zinvol, geen curve.

Eerst lichte stijging daarna kleine daling. Eén soort, Urtica dioica (Grote brandnetel).

2190-C Vochtige duinvalleien (ontkalkt) Toename in bedekking, daarna lichte afvlakking.

2310 Stuifzandheiden met struikhei Geen verdringingssoorten.

2320 Binnenlandse kraaiheibegroeiingen Rechte lijn, indifferent. Alleen Pinus sylvestris (Grove den) als verdringingsoort over. Meer onderzoek is nodig, want potentieel zijn er

$2330 \quad$ Zandverstuivingen wel verdringingssoorten voor dit type. 


\begin{tabular}{|c|c|c|c|}
\hline Habitat & Naam habitattype & Omschrijving curve & $\begin{array}{l}\text { Betrouwbaar/ } \\
\text { onbetrouwbaar }\end{array}$ \\
\hline 3110 & Zeer zwakgebufferde vennen & $\begin{array}{l}\text { Stijgende lijn. Drie soorten, waaronder Sphagnum auriculatum (Geoord veenmos), maar het is de vraag of dat een verdringingssoort } \\
\text { is. }\end{array}$ & Goed \\
\hline 3140 & Kranswierwateren & $\begin{array}{l}\text { Stijgende lijn. Juncus bulbosus (Knolrus) vlakt af en Potamogeton polygonifolius (Duizendknoopfonteinkruid) daalt licht na } \\
\text { aanvankelijk sterke stijging. }\end{array}$ & Goed \\
\hline 3150 & $\begin{array}{l}\text { Meren met krabbenscheer en } \\
\text { fonteinkruiden }\end{array}$ & Watertype, geen verdringingssoorten. Ook ecologisch niet zinvol. & \\
\hline 3160 & Zure vennen & $\begin{array}{l}\text { Stijgende lijn. Sphagnum auriculatum (Geoord veenmos) neemt als kwalificerende soort toe. Deze is nu toegevoegd al } \\
\text { verdringingssoort, maar is dat terecht? }\end{array}$ & Goed \\
\hline 4010-A & $\begin{array}{l}\text { Vochtige heiden (hogere } \\
\text { zandgronden) }\end{array}$ & Stijgende lijn. & Goed \\
\hline $4010-B$ & Vochtige heiden (laagveengebied) & Stijgende lijn. & Goed \\
\hline 4030 & Droge heiden & $\begin{array}{l}\text { Licht stijgende lijn, daarna indifferent. Gebaseerd op slechts éen soort Campylopus introflexus (Grijs kronkelsteeltje), die juist meer } \\
\text { kenmerkend is als verdringingssoort in } 2310 \text { en } 2330 . \text { Bekende vergrassers als Avena flexuosa (Bochtige smele) en Molinea caerulea } \\
\text { (Pijpenstrootje) zijn afgevallen, omdat ze om onbekende redenen geen toename lieten zien. }\end{array}$ & Slech \\
\hline 5130 & Jeneverbesstruwelen & Sterk stijgende lijn. & Goed \\
\hline 6120 & Stroomdalgraslanden & Stijgende curve. & Goed \\
\hline 6130 & Zinkweiden & Stijgende lijn. Op basis van drie soorten. & Goed \\
\hline 6210 & Kalkgraslanden & Sterke toename in bedekking. & Goed \\
\hline 6230 & Heischrale graslanden & Zeer sterke toename in bedekking. & Goed \\
\hline 6410 & Blauwgraslanden & Sterke toename in bedekking. & Goed \\
\hline $6430-\mathrm{C}$ & $\begin{array}{l}\text { Ruigten en zomen (droge } \\
\text { bosranden) }\end{array}$ & $\begin{array}{l}\text { Stijgende en later enigszins afvlakkende curve. Cruciata laevipes (Kruisbladwalstro) en Urtica dioica (Grote brandnetel) neemt wel toe. } \\
\text { Matig vanwege niet sterk toenemende bedekking. }\end{array}$ & Matig \\
\hline $6510-A$ & $\begin{array}{l}\text { Glanshaver- en } \\
\text { vossenstaarthooilanden (glanshaver) }\end{array}$ & Stijgende curve, daarna enigszins afvlakkend. & Goed \\
\hline $6510-B$ & $\begin{array}{l}\text { Glanshaver- en } \\
\text { vossenstaarthooilanden (grote } \\
\text { vossenstaart) }\end{array}$ & $\begin{array}{l}\text { Stijgende curve, zij het slechts op basis van één soort, Holcus lanatus (Gestreepte witbol). Verdringing wordt ook van andere } \\
\text { grassoorten verwacht. }\end{array}$ & Goed \\
\hline $7110-\mathrm{A}$ & $\begin{array}{l}\text { Actieve hoogvenen } \\
\text { (hoogveenlandschap) }\end{array}$ & Stijgende lijn. & Goed \\
\hline 7110-B & Actieve hoogvenen (heideveentjes) & Stijgende lijn. & Goed \\
\hline 7120 & Herstellende hoogvenen & Stijgende lijn. & Goed \\
\hline
\end{tabular}


7140-A Overgangs- en trilvenen (trilvenen) Stijgende lijn, later licht afvlakkend.

7140-B Overgangs- en trilvenen Stijgende lijn, later licht afvlakkend.

(veenmosrietlanden)

7150 Pioniervegetaties met snavelbiezen

7210 Galigaanmoerassen

Stijgende lijn, later enigszins afvlakkend. Eén soort, Molinia caerulea (Pijpenstrootje). Toename in bedekking is niet groot. Stijgende lijn, later afvlakkend tot bijna onveranderlijk.

Kalktufbronnen Geen verdringingssoorten.

$7230 \quad$ Kalkmoerassen Sterk stijgende curve.

Veldbies-beukenbossen

Eerst zeer licht stijgend, daarna dalend. Verschil in bedekking is gering. Eén soort, Urtica dioica (Grote brandnetel).

9120 Beuken-eikenbossen met hulst Eerst licht stijgend, daarna dalend. Twee soorten, toename in bedekking is gering.

160-A Eiken-haagbeukenbossen (hogere Bostype, geen verdringingssoorten en tevens ecologisch niet zinvol. zandgronden)

9160-B Eiken-haagbeukenbossen (heuvelland)

9190 Oude eikenbossen

91D0 Hoogveenbossen

91E0-A Vochtige alluviale bossen

(zachthoutooibossen)

91E0-B Vochtige alluviale bossen (esseniepenbossen)

91E0-C Vochtige alluviale bossen (beekbegeleidende bossen) neemt toe in Nederland en kan soorten verdringen, maar is dat een klimaat- of een stikstofeffect? Geringe stijging en daarna lichte daling. Eén soort, Avenella flexuosa (Bochtige smele).

Min of meer vlakke lijn. Eén soort, Molinia caerulea (Pijpenstrootje). Bostype, ecologisch niet zinvol, geen curve.

Bostype, ecologisch niet zinvol, geen curve. 


\section{B.3.3 Discussie}

Bij de opzet van dit onderzoek was het streven om verdringingssoorten te definiëren op basis van veldkennis. Daarvoor is in eerste instantie gebruikgemaakt van expertise van ecologen: de soorten die worden gegeven in de herstelstrategieën (Smits et al., 2016) en het recentelijk gereedgekomen werk van Oosterlynck et al. (2020). De tussentijdse resultaten lieten echter zien dat een aanzienlijk deel van de geselecteerde verdringingssoorten geen toename in de bedekking vertoonde bij toenemende depositie. Daarom heeft een nadere selectie plaatsgevonden op basis van de geschatte responscurven.

Voor een aantal bekende verdringingssoorten, zoals Gewone braam, Pijpenstrootje en Bochtige smele, worden in een deel van de gevallen onbegrijpelijke curven geschat.

Op basis van ecologische kennis is besloten om voor een deel van de bossen en alle stromende wateren geen responscurven voor verdringingssoorten te schatten. In ten minste een deel van de bossen werkt het principe van verdringingssoorten waarschijnlijk niet goed; er spelen andere processen, zoals veroudering van het bos, en de ondergroei wordt waarschijnlijk niet altijd beïnvloed door de bedekking van verdringingssoorten. Voor wateren geldt dat fosfaat en instroom van voedselrijk water waarschijnlijk een grotere rol spelen dan directe depositie. De herstelstrategieën (Smits et al., 2016) en de daarin genoemde 'verdringingssoorten' zijn leidend geweest voor de keuze om geen curven te schatten voor een habitattype. Daarom zijn voor typen waar geen verdringingssoorten worden gegeven geen curven geschat.

Ondanks dat een aantal curven als plausibel is beoordeeld, moet de methode nog verbeterd worden, vooral wat betreft de selectie van verdringingssoorten. Een deel van de nu geselecteerde soorten vertoont volgens de berekeningen slechts een beperkte reactie. In hoeverre andere processen die niet zijn meegenomen als covariabele hierbij een rol spelen, is onbekend.

Een specifiek punt van aandacht is het feit dat de resultaten alleen gebaseerd zijn op positieve waarnemingen. Opnamen waarin de soort niet voorkomt als gevolg van stikstofdepositie worden niet meegenomen. Het is niet uitgesloten dat een soort in veel opnamen met een lage bedekking voorkomen, maar bij hoge depositie alleen toevallig (of door een andere factor dan depositie) in een beperkt aantal opnamen met hoge bedekking voorkomt. Of dit soort toevalligheden een grote invloed hebben op de resultaten, moet nader worden onderzocht.

In ieder geval geldt dat verdringingssoorten alleen dán terecht als zodanig zijn geselecteerd als (andere) kwalificerende soorten erdoor afnemen. Daarom behoren de responscurven voor de bedekking van de verdringingssoorten vergeleken te worden met de responscurven voor de kwalificerende soorten.

\section{B.4 Betrouwbaarheid van de geschatte responscurven}

Bij het schatten van de responscurven voor soorten en habitattypen is nog geen kwantitatieve gevoeligheids- en onzekerheidsanalyse uitgevoerd. Omdat de onzekerheid in de meeste gebruikte invoergegevens bekend is, is een kwantitatieve analyse in principe mogelijk. De onzekerheid in de geschatte curven voor soorten en habitattypen kan bijvoorbeeld in beeld gebracht worden met een bootstrap-methode (Wamelink et al., 2005). Onzekerheid in de curven als gevolg van onzekerheid in de verschillende invoergegevens vergt een uitgebreider onderzoek. Dit was echter in de beschikbare tijd niet mogelijk. Hieronder wordt een kwalitatieve onzekerheidsanalyse gegeven ten aanzien van een viertal aspecten. Daarna wordt de mogelijke gevoeligheid van de gemaakte keuze voor de uitkomsten besproken.

\section{B.4.1 Data}

Stikstofdepositie: De onzekerheid in de EMEP-gegevens voor stikstofdepositie is redelijk groot, met name verder terug in de tijd, maar ook in gebieden met grote lokale verschillen. Het is onbekend hoe de gevolgde procedure om betere schattingen van de stikstofdepositie te verkrijgen de onzekerheid 
heeft beïnvloed. In vergelijking met nationale depositiekaarten hebben EMEP-gegevens een grotere onzekerheid, mede door verschillen in de schaal waarop landelijk gegevens worden verzameld.

Meteorologische gegevens: De gegevens over temperatuur en neerslag worden door weerstations met een grote nauwkeurigheid en dus kleine onzekerheid geschat. Deze gegevens zijn geïnterpoleerd naar de coördinaten van de vegetatieopnamen, wat met name voor de neerslag onzekerheid geeft. De responscurve wordt mede vanwege de normalisatie beïnvloed door het effect van meteorologische gegevens (temperatuur en neerslag en de interactie tussen beide). De meeste curven wijken na correctie voor weergegevens af van de curve zonder de covariabelen en van de curve op basis van de covariabele bodemtype. Er is niet nagegaan welke van de weervariabelen het bepalendst zijn en of kan worden volstaan met temperatuur of neerslag. Dat dient nader te worden onderzocht.

Bodemtypen: De onzekerheid in de bodemtypen is vrij groot, vooral wat betreft de ruimtelijke resolutie. Het geeft bijvoorbeeld te denken dat löss volgens de gebruikte bodemkaart niet in Nederland voorkomt. Het is onduidelijk of de groepering van bodemtypen de onzekerheid vergroot dan wel verkleint. Jonge bodems bevatten bijvoorbeeld een veelheid aan bodemtypen die wellicht beter onderscheiden zouden moeten worden. Het zal lastig zijn om de kaart-onzekerheid te kwantificeren. De gebruikte kaart is echter de enige die op Europese schaal beschikbaar is. De kaart bevat andere mogelijkheden, zoals het lutumgehalte van de bodem, om het effect van de bodem mee te nemen als covariabele en dat zou betrouwbaarder kunnen zijn dan de bodemtypen zelf. Dat dient nader te worden onderzocht.

Vegetatieopnamen: Mogelijk bevat een deel van de opnamen verkeerde coördinaten. Deze fouten zijn moeilijk op te sporen (tenzij de locatie midden in zee ligt). Foute coördinaten werken door in de gekoppelde stikstofdepositie, temperatuur, neerslag en bodemtype. Het aandeel foute coördinaten in de EVA-database wordt overigens klein geacht. De database is gecontroleerd en voldoet aan gedefinieerde criteria (Chytrý et al., 2016).

\section{B.4.2 Methodiek: Koppeling van soorten aan habitattypen, EUNIS- typen en structuurtypen}

Een belangrijke schakel in het schatten van de responscurven is de koppeling van soorten aan de habitattypen. Dat is nu, behalve bij de typische soorten, gebaseerd op rekenregels, toegepast op de database behorend bij De Vegetatie van Nederland (SynBioSys;

https://www.synbiosys.alterra.nl/synbiosysnl) die representatief wordt geacht voor Nederland. Er kunnen echter soorten ontbreken en soorten kunnen onterecht geselecteerd zijn. De soortenlijst is door experts beoordeeld en is mede daardoor behoorlijk zeker. De resultaten laten echter zien dat mogelijk toch ten dele sprake is van een maskering van stikstofeffecten, zoals ook is geconstateerd in Deel A. Het resultaat kan sterk beïnvloed worden indien de soortenlijst van een habitattype ook een grote aantal soorten bevat die ook voorkomen buiten de beschermde habitattypen (en die daarmee niet behoren tot de soorten waar de aandacht van die bescherming naar uitgaat). Dit ongewenste effect van een ruime soortenselectie is in nog grotere mate problematisch als een kwalificerende soort ook een verdringingssoort blijkt te zijn.

De responscurven voor habitattypen zijn zeer gevoelig voor het aantal kwalificerende soorten. Een aanwijzing hiervoor is dat typen met weinig soorten vaker een niet-plausibele responscurve vertonen. Dat effect is uiteraard met name groot als een klein aantal soorten ook nog eens voor een belangrijk deel bestaat uit algemeen voorkomende soorten of zelfs verdringingssoorten. Hoewel er in deze verkenning veel tijd is besteed aan een zo goed mogelijke selectie van soorten, is het duidelijk dat hier nader onderzoek noodzakelijk is.

Voor de koppeling van vegetatieopnamen aan EUNIS-typen, en daarmee aan vegetatiestructuurtypen, is gebruikgemaakt van expertregels (Chytrý et al., 2020). Foute toekenningen werken door in het bepalen van de dataset van een soort-/structuurtypecombinatie en daarmee in de geschatte responscurven van soorten en habitattypen. Het effect hiervan wordt als klein ingeschat. 
De koppeling van structuurtypen aan habitattypen is vrij grof. Deze koppeling wordt gebruikt voor het schatten van meer specifieke curven voor de bij het habitattype behorende soorten. De koppeling is echter niet probleemloos. Zo is een deel van de opnamen met vergraste heiden door de genoemde expertregels tot 'droge graslanden' gerekend en niet tot de 'droge dwergstruiken'. Hierdoor zijn ze niet meegenomen bij het schatten van de soorten behorende bij natte heide en droge heide. Dit resulteerde in een twijfelachtige curve voor bijvoorbeeld Molinea caerulea (Pijpenstrootje). Een ander voorbeeld zijn de struwelen die nu tot bos zijn gerekend. Dit gaf afwijkende responscurven die mogelijk met deze toekenning te maken hebben. Voor specifieke soorten kan het effect van de toekenning dus groot zijn.

De resultaten met de afzonderlijke covariabelen (Bijlage 9) geven enig inzicht in de gevoeligheid van de responscurve voor de keuze van covariabelen. De covariabele landcode (dus het land binnen het selectiegebied waarin een opname is gemaakt) gaf onverklaarbare resultaten en is daarom verder niet gebruikt. Een nader onderzoek hiernaar is wel gewenst. Ten opzichte van de responscurve zonder covariabelen geven de andere covariabelen allemaal een effect te zien, al verschilt dat van soort tot soort. Er zijn ook soorten waarbij de covariabelen nauwelijks of geen effect op de responscurve hebben. Om goed inzicht te krijgen, zouden alle soort-/structuurtypecombinaties moeten worden geëvalueerd, waarbij ook de responses van een soort voor verschillende structuurtypen zouden moeten worden meegenomen, zodat de vraag kan worden beantwoord of er verschillen zijn in de responscurve voor een soort in verschillende structuurtypen. 


\title{
Integratie van empirische en statistische relaties
}

\author{
G.W.W. Wamelink, P.W. Goedhart \& R. Bobbink
}

\section{C.1 Inleiding}

In dit onderzoek zijn volgens twee onafhankelijke methoden de responsies van habitattypen voor stikstofdepositie in beeld gebracht.

De eerste methode (Deel A) is gebaseerd op gradiëntstudies in het veld. Hierbij wordt een verband gelegd tussen stikstofdepositie en het voorkomen van soorten voor een beperkt aantal vegetatietypen. Voor deze studies is altijd het totaal aantal soorten dat voorkomt beschikbaar en vaak ook een onderverdeling naar deelverzamelingen daarvan. De vegetatietypen zijn vertaald naar habitattypen. De verkregen resultaten worden empirische dosis-effectrelaties genoemd.

De tweede methode (Deel B) legt een statistisch verband tussen stikstofdepositie en soorten uit vegetatieopnamen. Dat gebeurt op twee manieren: op basis van aan- en afwezigheid van kwalificerende soorten op basis van de bedekking van verdringingssoorten. De curven per soort zijn vervolgens gecombineerd om een responscurve per habitattype te verkrijgen. De verkregen resultaten worden statistische dosis-effectrelaties genoemd.

Beide methoden maken gebruik van verschillende onafhankelijke data en hebben een verschillende aanpak. De resultaten van beide methoden worden in dit deel vergeleken, waarbij de statistische relaties gevalideerd worden door de bij het habitattype behorende empirische relaties. Dit is slechts mogelijk voor een beperkt aantal habitattypen.

Omdat beide relaties een verschillende eenheid hebben (aantal soorten versus een gemiddelde genormaliseerde kans), zijn ze niet direct vergelijkbaar. De vergelijking betreft daarom vooral de vorm van de curve.

\section{C.2 Methode}

De empirische waarden zijn bepaald voor vrij breed gedefinieerde vegetatietypen (zie Deel A). Aan elk type uit Deel A zijn een of meerdere habitat(sub)typen uit Deel B gekoppeld (Tabel 14). Omdat het aantal habitattypen met empirische waarden zeer beperkt is, is de koppeling vrij ruim genomen en worden de responscurven van soms meerdere vergelijkbare habitattypen vergeleken met dezelfde empirische data. Daarbij was dus de aanname dat de resultaten voor het brede type uit Deel $A$ voldoende toepasbaar zijn voor de daaraan gekoppelde habitat(sub)typen uit Deel B. De gebruikte combinaties zijn:

- Voor Droge duingraslanden worden alle drie de subtypen van Grijze duinen (2130; kalkrijk, kalkarm en heischraal) als direct vergelijkbaar beschouwd.

- Voor Droge heiden is Droge heiden (4030) direct passend en zijn Duinheiden met kraaihei (droog, 2140-B), Duinheide met struikhei (2150) en Stuifzandheiden met struikhei (2310) ook getoetst, omdat het om vergelijkbare typen gaat met ook deels dezelfde kwalificerende soorten.

- Kalkgraslanden zijn vergeleken met de direct passende Kalkgraslanden (6210) en het voor Nederland vergelijkbare type Pionierbegroeiingen op rotsbodem (6110). Daarbij worden de resultaten gebruikt van zowel de studie in het Verenigd Koninkrijk als van de studie in de Atlantische regio.

- De empirische data voor Heischrale graslanden is alleen vergeleken met het direct passende Heischrale graslanden (6230). 
- Montane graslanden komen in Nederland niet voor, maar ze worden voldoende vergelijkbaar geacht met Stroomdalgraslanden (6230) en met de twee subtypen van Glanshaver- en vossenstaarthooilanden (6510; glanshaver en grote vossenstaart), vooral wat betreft de oligotrafente soorten.

- De empirische data voor Hoogvenen zijn vergeleken met de direct passende typen Actieve hoogvenen (7110; beide subtypen: hoogveenlandschap en heideveentjes) en Herstellende hoogvenen (7120). Daarbij worden de resultaten gebruikt van zowel de studie in het Verenigd Koninkrijk als van de studie in Noorwegen.

- De Atlantische Eikenbossen uit Ierland zijn nauw verwant aan de in Nederland voorkomende Oude eikenbossen (9190) en een deel van de Beuken-eikenbossen met hulst (9120). Ze zijn echter ook vergeleken met de minder verwante Duinbossen, subtype droog (2180-A) en vochtig (2180-B), de Veldbies-beukenbossen (9110), en de beide subtypen van de Eiken-haagbeukenbossen (9160; hogere zandgronden en heuvelland).

De empirische dosis-effectrelaties bestaan altijd uit datasets met aantallen soorten die voorkomen bij een depositie-interval. In de meeste gevallen is er een onderverdeling naar deelverzamelingen beschikbaar; ook deze zijn gebruikt voor validatie en worden apart weergegeven. De empirische waarden zijn, met het bijbehorende 95\%-betrouwbaarheidsinterval, uitgezet in een figuur, waarbij het klassenmidden van de depositie-intervallen is gebruikt als verklarende variabele (x-as). De statistische responscurven zijn feitelijk dimensieloos, waardoor een directe vergelijking met de empirische data niet mogelijk is. Daarom worden de statistische responscurven vermenigvuldigd met een constante factor, zodanig dat, na vermenigvuldiging, Lin's concordance correlation coëfficiënt $\rho$ (Lin, 1989) tussen de empirische waarden en de vermenigvuldigde waarden maximaal is. Lin's coëfficiënt is een veelgebruikte maat om de overeenstemming tussen twee variabelen te bepalen. Voor twee identieke variabelen is Lin's coëfficiënt gelijk aan 1 . Na deze vermenigvuldiging is de responscurve in dezelfde figuur geplot.

De mate van overeenstemming tussen de empirische waarden en de vermenigvuldigde responscurven is beoordeeld door de auteurs. Daarbij is ook gebruikgemaakt van de reacties die enkele leden van de begeleidingscommissie hebben gegeven. In de figuren (zie de volgende paragraaf) is het eindoordeel met een grote stip aangegeven, met kleurcoderingen groen voor goed, geel voor matig en rood voor slecht. De vijf kleine stippen geven de beoordelingen door afzonderlijke experts. Uiteindelijk heeft de berekening volgens Lin's coëfficiënt de doorslag gegeven. Bijvoorbeeld: als er twee of drie beoordelingen matig zijn en de andere goed en de Lin's coëfficiënt is hoog, dan is het eindoordeel goed.

\section{C.3 Resultaten}

Voor 23 habitattypen met een statistische responscurve voor stikstofdepositie is een vergelijking gemaakt met 7 verschillende vegetatietypen waarvoor empirische dosis-effectrelaties beschikbaar zijn. Voor een aantal typen is een vergelijking gemaakt voor alle soorten in de opnamen en voor een deelverzameling van soorten. In totaal levert dit 41 combinaties op die beoordeeld zijn. De mate van overeenstemming (goed, matig, slecht) tussen de responscurve en de empirische data is gegeven in Tabel 14. Figuur 64 tot en met Figuur 70 bevatten een grafische representatie van de vergelijking uit Tabel 14, waarin ook de beoordeling via de kleurcodering wordt gegeven.

De empirische waarden voor Droge duingraslanden zijn vergeleken met de responscurven voor alle drie de subtypen voor Grijze duinen (2130; kalkrijk, kalkarm en heischraal, Figuur 64abc). De drie responscurven voor de drie subtypen, die nauwelijks van elkaar afwijken, lopen door de betrouwbaarheidsintervallen van de empirische waarden. Het aantal en de range van de empirische stikstofdeposities zijn helaas beperkt, waardoor er boven de $15 \mathrm{~kg} / \mathrm{ha} / \mathrm{j}$. geen vergelijking mogelijk is. De trend wordt voor alle subtypen goed weergegeven. De daling van de curve zet zich door tot vrijwel de hoogste depositie van $55 \mathrm{~kg} / \mathrm{ha} / \mathrm{j}$., waarbij de curve dus een min of meer constante geleidelijke daling laat zien, met een lichte afvlakking bij zeer hoge deposities. 
De empirische waarden voor Droge heiden zijn in Figuur 64d vergeleken met de responscurve voor Duinheiden met kraaihei (droog, 2140B). De geschatte responscurve volgt de empirische waarden en geeft naast de daling bij lagere deposities ook het begin van de afvlakking bij hogere depositie. $\mathrm{Na}$ een vrij steile daling tot $20 \mathrm{~kg} / \mathrm{ha} / \mathrm{j}$. vlakt de curve af en wordt het aantal soorten niet meer lager.

De empirische waarden voor Droge heiden zijn in Figuur 64e vergeleken met de responscurve voor Duinheiden met struikhei (2150), die een vergelijkbare responscurve heeft als Duinheiden met kraaihei. De responscurve volgt vrijwel exact de empirische data. Na een snelle daling wordt een stabiel minimum bereikt bij ongeveer $30 \mathrm{~kg} / \mathrm{ha} / \mathrm{j}$. stikstofdepositie.

Voor Stuifzandheiden met struikhei is het beeld vrijwel gelijk aan die voor de duinheiden met Kraaihei en struikhei, zie Figuur 64f. De lijn volgt de empirische data vrij nauwkeurig. In het gedeelte bij hoge deposities, waar geen empirische data meer beschikbaar zijn, gaat de responscurve enigszins omhoog.

Droge heide (4030) zelf geeft een responscurve die iets verder daalt dan de empirische waarden voor Calluna-heide, net als bij Duinheiden met kraaihei (droog, 2140B; zie Figuur 65a). Het verschil is echter klein. Net als Stuifzandheiden met struikhei zit er een klein knikje in de curve omhoog, die daarna weer afvlakt.

De empirische waarden voor Kalkgraslanden zijn vergeleken met de responscurve voor Pionierbegroeiingen op rotsbodem (6110; Figuur 65bcd). De responscurve volgt de empirische waarden vrij goed voor de deelverzameling van Mesobromion-soorten van de studie uit de Atlantische regio, vooral bij de laagste deposities (a). De curve duikt vrij steil naar beneden tussen de één na hoogste en hoogste empirische depositiewaarden, waar de empirische depositie dat nog niet doet. Er is geen overeenstemming met de empirische waarden van de totale soortenrijkdom (b), omdat deze vrijwel geen relatie met depositie laat zien. De relatie voor het totaalaantal soorten van de dataset uit het Verenigd Koninkrijk (c) heeft een lagere $\rho$ in vergelijking met de Mesobromion-soorten, ook al is er op het oog niet zoveel verschil.

De empirische waarden voor Kalkgraslanden (6210) zijn vergeleken met beide beschikbare datasets voor de empirische waarden (UK en BEGIN), waarbij de BEGIN-dataset naast het totaalaantal soorten ook een aparte lijst heeft voor Mesobromion-soorten (Figuur 65ef en Figuur 66a). De responscurve voor kalkgrasland volgt de empirische data goed tot zeer goed. Net als voor Pionierbegroeiingen op rotsbodem (Fig. 65d) gaat de curve vrij steil naar beneden met een snelle afname bij hogere deposities. Dit ligt echter buiten de range waarvoor empirische data beschikbaar zijn. Opvallend is dat zowel de curve als de empirische data na een eerste daling een soort plateau vertonen.

De empirische waarden voor Heischraal grasland (6230) zijn gebruikt om de responscurve voor Heischrale graslanden (6230) mee te vergelijken, voor het totaalaantal soorten en voor de deelverzameling kruiden (Figuur 66bc). Zowel de soortaantallen als de responscurve vertonen een dalende lijn bij hogere depositie. De curve volgt de empirische waarden goed, zowel voor het totaalaantal soorten als voor het totaalaantal kruiden. De overeenkomst met het totaalaantal soorten is het best. Dat zou verklaard kunnen worden uit het feit dat de statistische responscurve bepaald wordt door meer soorten dan alleen kruiden.

De empirische waarden voor De dataset met Montane graslanden (6520) zijn vergeleken met de responscurve voor de vergelijking met drie Nederlandse habitat(sub)typen: Stroomdalgraslanden (6120, Figuur 66de), Glanshaver- en vossenstaarthooilanden (glanshaver, 6510-A, Figuur 66f en Figuur 67a) en Glanshaver- en vossenstaarthooilanden (grote vossenstaart, 6510-B, Figuur 67bc). Daarbij zijn steeds eerst de resultaten gepresenteerd van de deelverzameling van 'oligotrofe soorten' (soorten van de voor Montane graslanden kenmerkende, voedselarme omstandigheden). De overeenkomst tussen de responscurven en de empirische data is in de meeste gevallen slecht. Alleen de Stroomdalgraslanden volgen de empirische gegevens van het totaalaantal soorten goed genoeg. Dit bevestigt het in Deel B gegeven oordeel dat de soortenselectie voor Glanshaver- en vossenstaarthooilanden te breed is geweest, waardoor een te vlakke responscurve ontstaat. 
Voor hoogveen zijn twee datasets met empirische waarden beschikbaar, een uit Noorwegen en een uit het Verenigd Koninkrijk. Beide zijn gebruikt voor de vergelijking met de responscurven voor Actieve hoogvenen (hoogveenlandschap, 7110-A, Figuur 67de), Actieve hoogvenen (heideveentjes, 7110-B, Figuur 67f en Figuur 68a) en Herstellende hoogvenen (7120, Figuur 68bc). Alle drie de responscurven geven een goede overeenkomst met de empirische waarden uit de Noorse dataset, al gaat het hier maar om drie waarnemingen. Daarnaast ligt de laagste empirische waarneming in het gebied van de depositie waar voor de responscurve extrapolatie plaatsvindt (gestippelde deel van de lijn). De responscurven komen slechts matig overeen met de dataset uit het Verenigd Koninkrijk. Bij deze empirische gegevens werd er geen significant verband aangetoond tussen de soortenrijkdom en de verschillende depositieniveaus, mogelijk om toevallige redenen (zie Deel A). Het is dan ook niet verwonderlijk dat de dalende responscurve daar slechts een matige overeenkomst mee vertoont: het ligt voor de hand dat de responscurven de daadwerkelijke trend beter weergeven dan de empirische waarden uit het Verenigd Koninkrijk.

De empirische waarden Atlantische eikenbossen (91A0) zijn gebruikt om een vergelijking te maken met een groot aantal bostypen: Duinbossen (droog, 2180-A, Figuur 68de), Duinbossen (vochtig, 2180-B, Figuur 68f en Figuur 69a), Veldbies-beukenbossen (9110, Figuur 69bc), Beuken-eikenbossen met hulst (9120, Figuur 69de), Eiken-haagbeukenbossen hogere zandgronden (9160-A, Figuur 69f en Figuur 70a), Eiken-haagbeukenbossen (heuvelland, 9160-B, Figuur 70bc) en Oude eikenbossen ( 9190 , Figuur 70de). De Atlantische eikenbossen-dataset bevat ook een subset van indicatorsoorten. De responscurven voor de bostypen Oude eikenbossen en de Duinbossen (droog) volgen de empirische waarden slecht. De curven zijn vrijwel vlak, waar de empirische data een dalende trend vertonen. Ook Beuken-eikenbossen met hulst hebben een beperkt dalende responscurve, maar ze volgen wat beter de empirische data ('matig'), vooral voor het totaalaantal soorten. Veldbies-beukenbossen, Eikenhaagbeukenbos (beide subtypen) en Duinbossen (vochtig) volgen de empirische waarden goed en geven eenzelfde dalende trend. Dat is opmerkelijk, omdat deze habitat(sub)typen floristisch minder verwant zijn aan Atlantische eikenbossen dan de drie eerstgenoemde habitat(sub)typen. 
2130-A

Grijze duinen (kalkrijk)

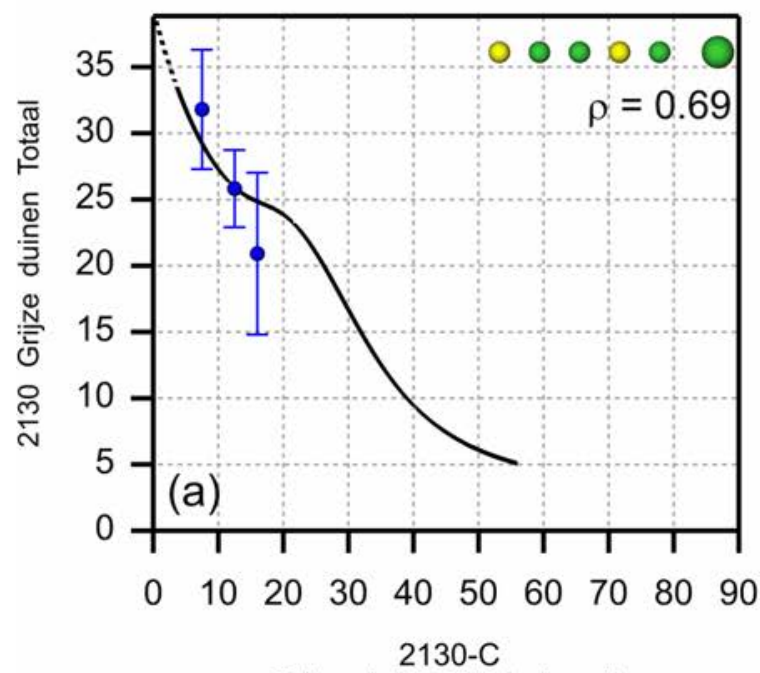

Grijze duinen (heischraal)

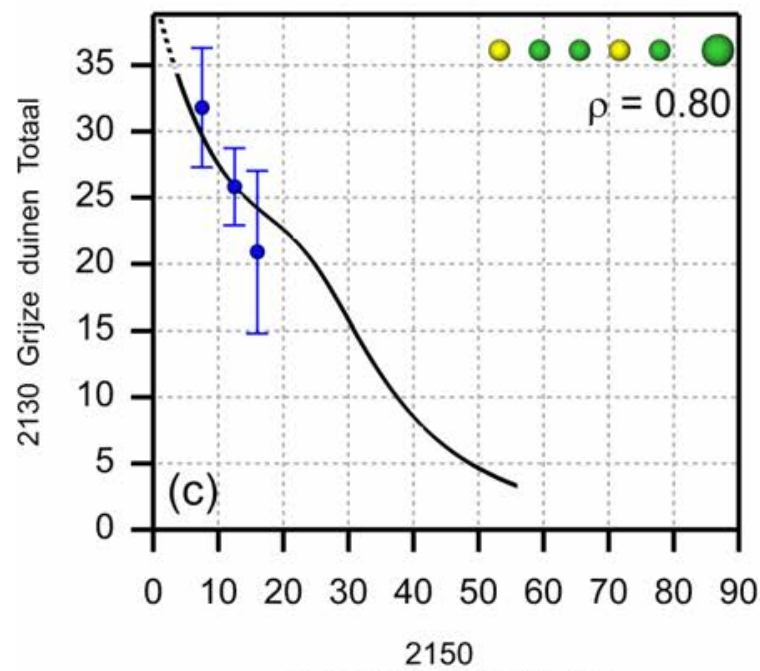

Duinheide met struikhei

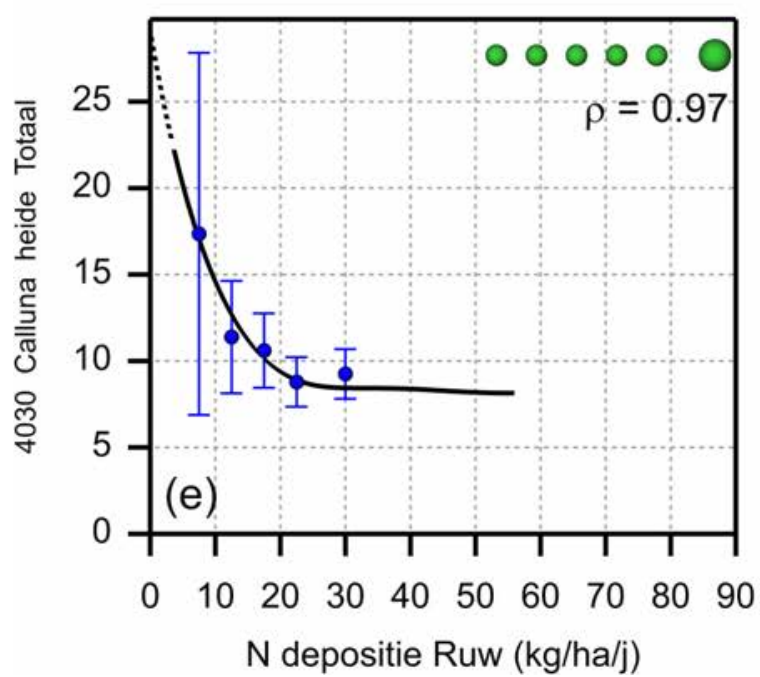

2130-B

Grijze duinen (kalkarm)

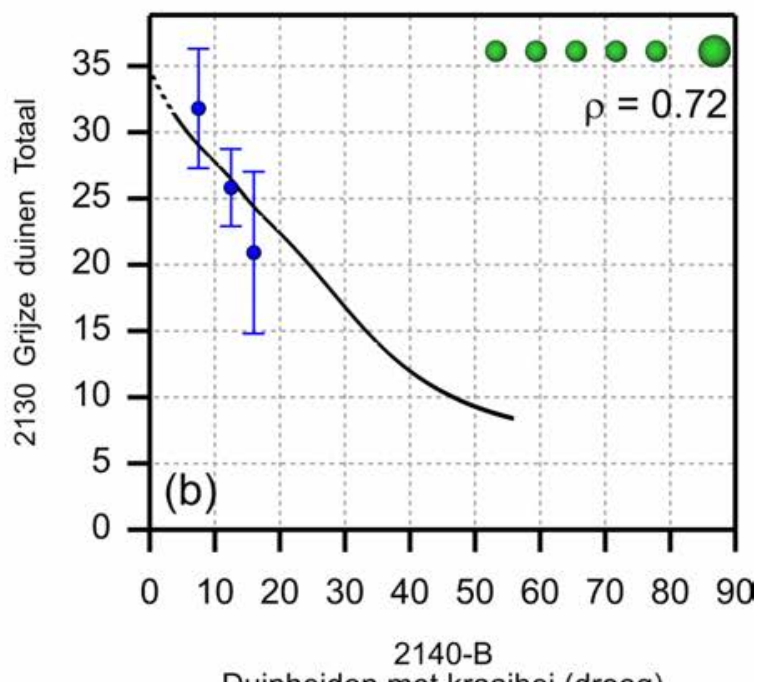

Duinheiden met kraaihei (droog)

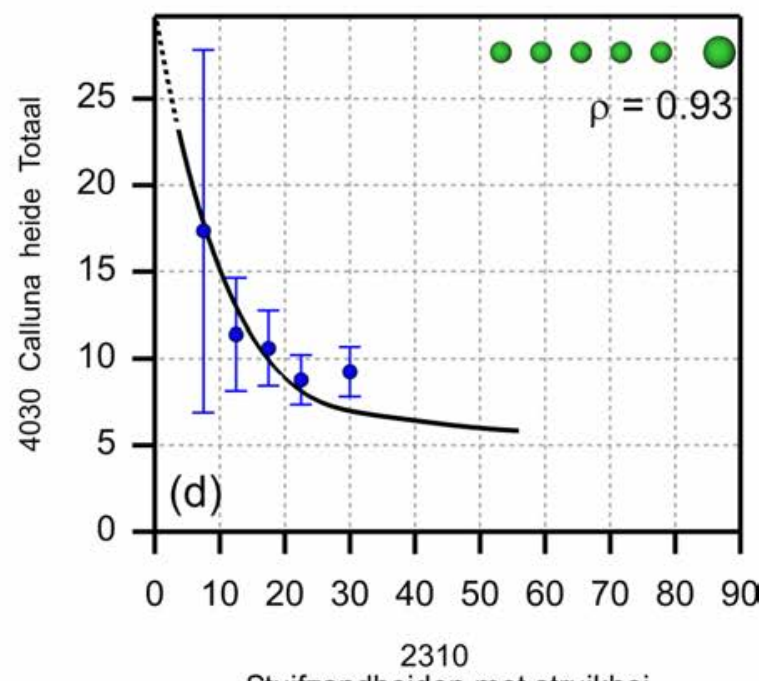

Stuifzandheiden met struikhei

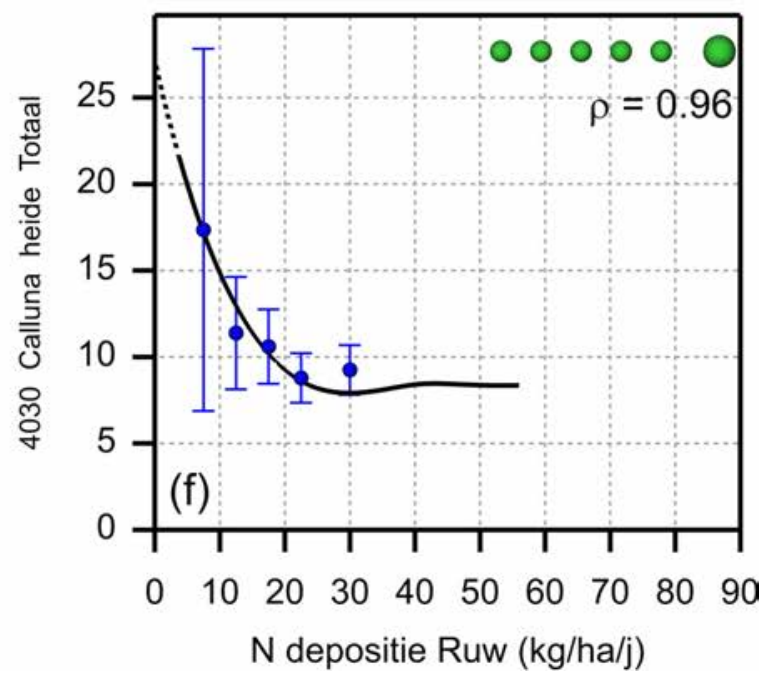

Figuur 61 Vergelijking, per habitattype, tussen empirische effecten (inclusief 95\%betrouwbaarheidsinterval, blauw) van stikstofdepositie op het aantal soorten en de vermenigvuldigde statistische responscurve. De kleurcoderingen geven de mate van overeenstemming aan zoals gegeven door een vijftal experts in Tabel 14 (groen=goed, geel=matig, rood=slecht), waarbij het eindoordeel groter is weergegeven. De $\rho$ geeft Lin's correlation coefficient of concordance tussen de empirische data en de responscurve. 


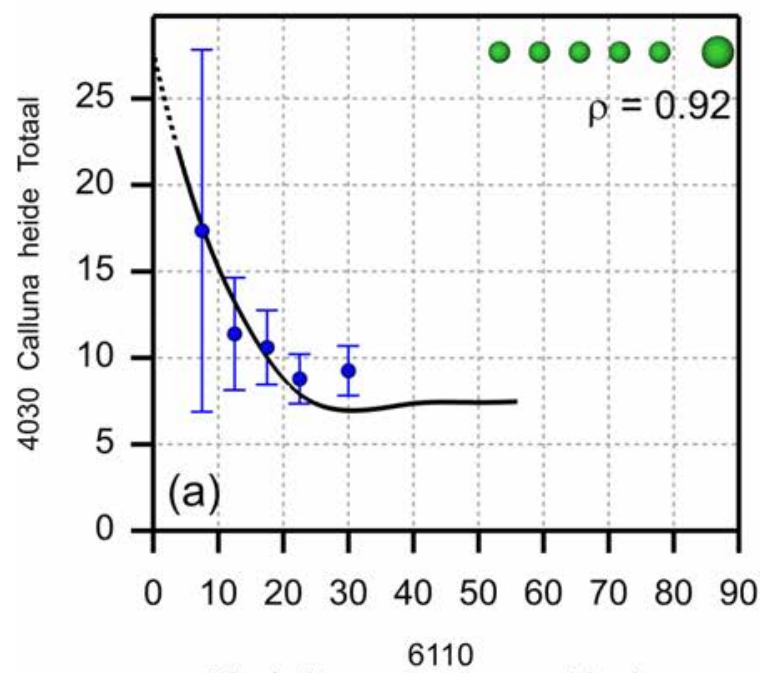

Pionierbegroeiingen op rotsbodem
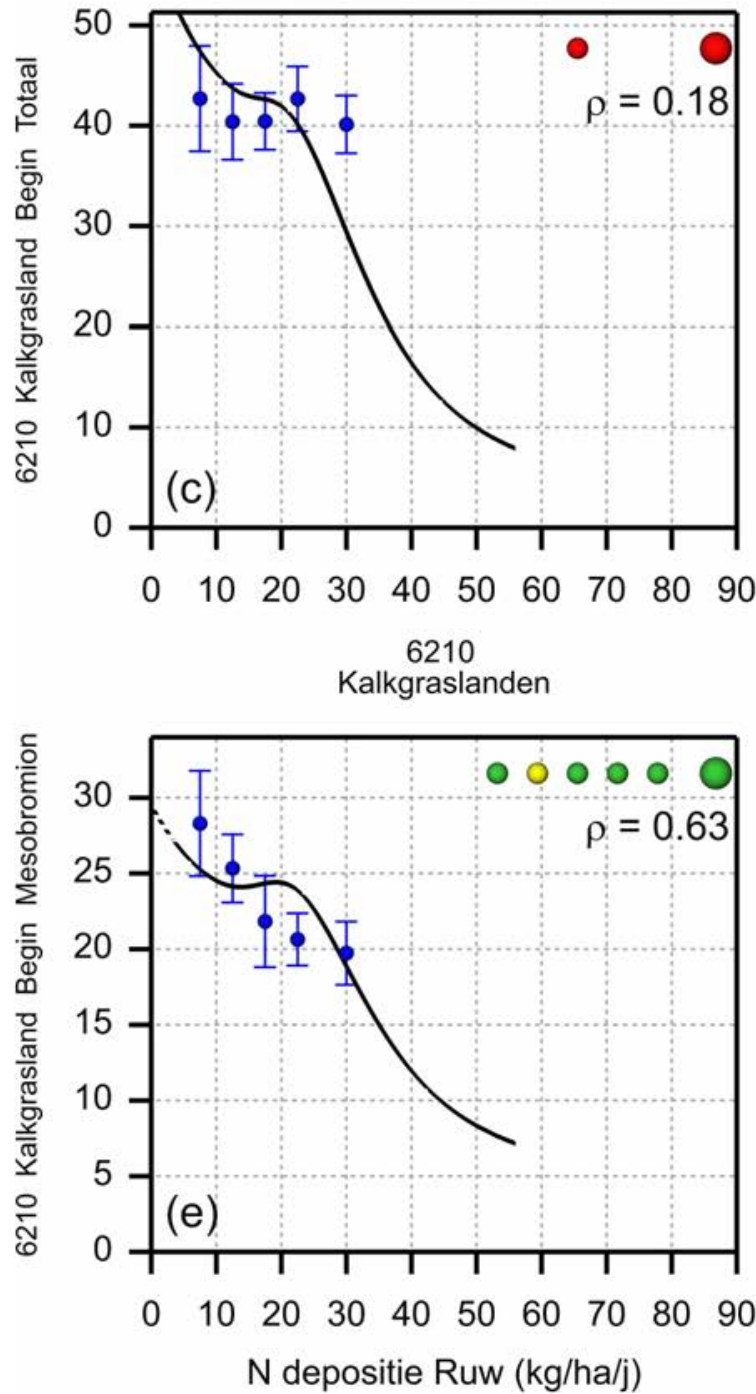

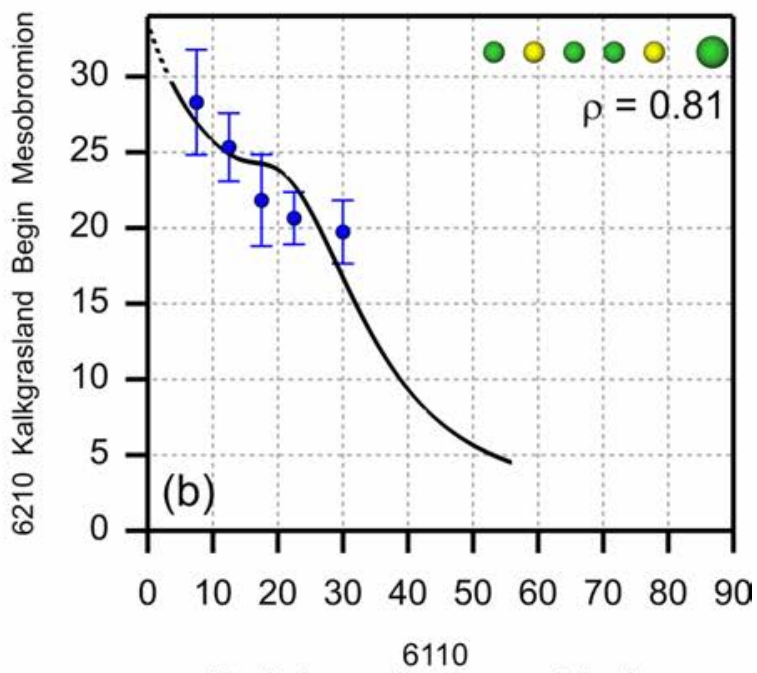

Pionierbegroeiingen op rotsbodem
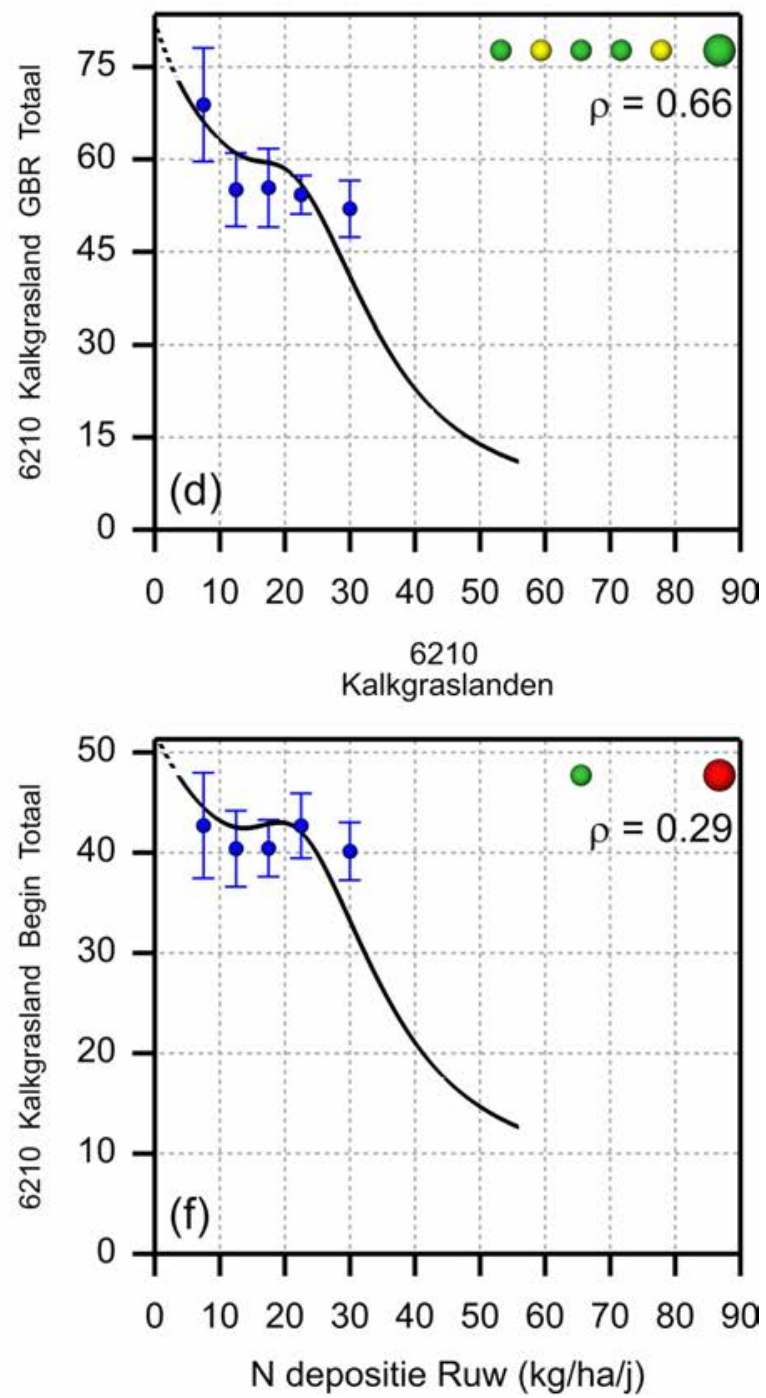

Figuur 62 Vergelijking, per habitattype, tussen empirische effecten (inclusief 95\%betrouwbaarheidsinterval, blauw) van stikstofdepositie op het aantal soorten en de vermenigvuldigde statistische responscurve. De kleurcoderingen geven de mate van overeenstemming aan zoals gegeven door een vijftal experts in Tabel 14 (groen=goed, geel=matig, rood=slecht), waarbij het eindoordeel groter is weergegeven. De $\rho$ geeft Lin's correlation coefficient of concordance tussen de empirische data en de responscurve. 


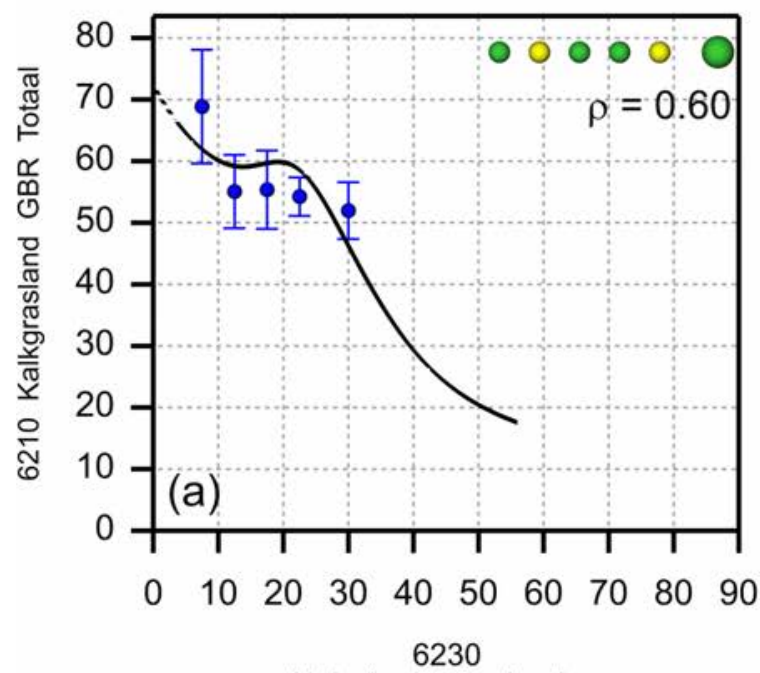

Heischrale graslanden
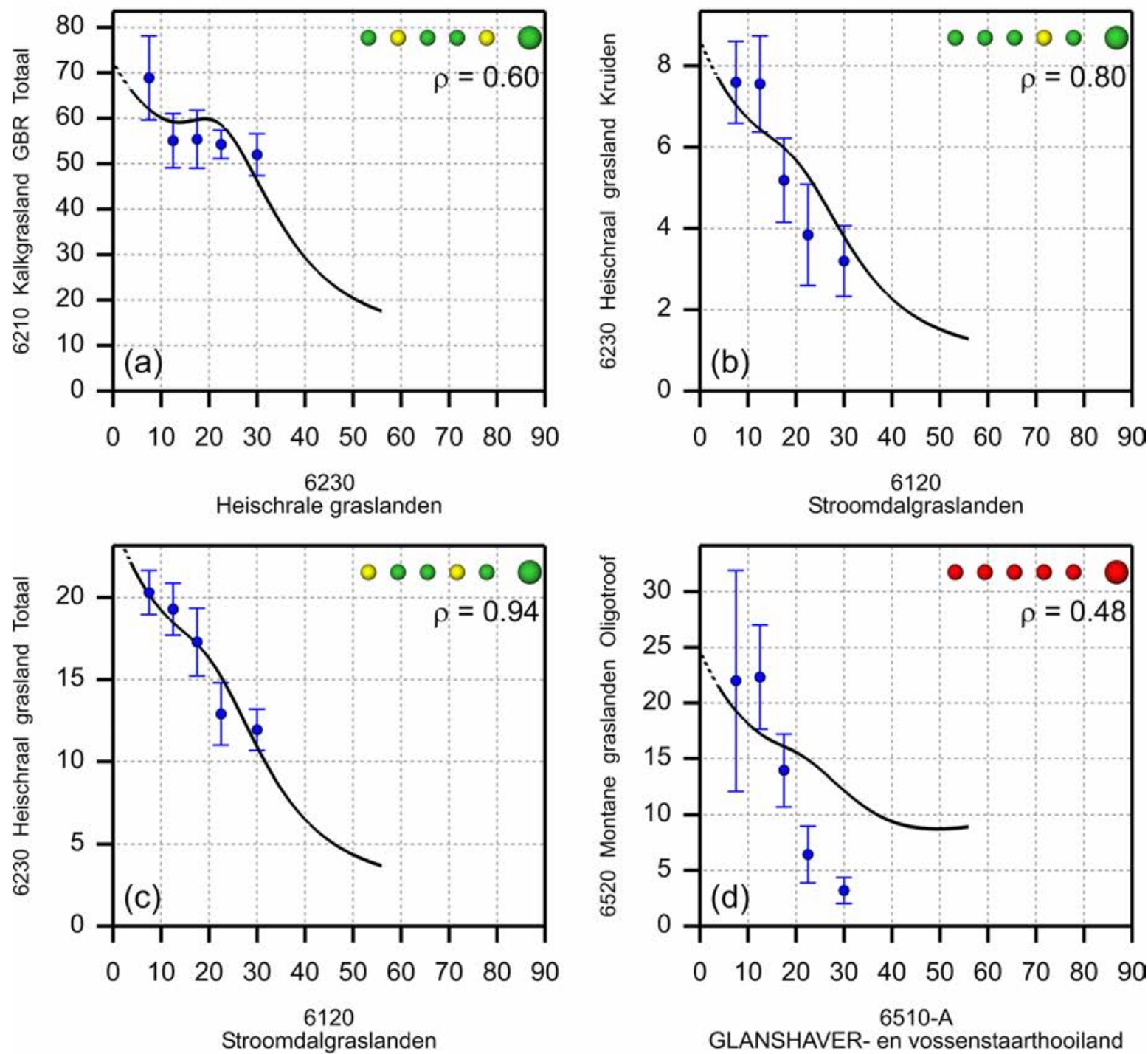

Stroomdalgraslanden
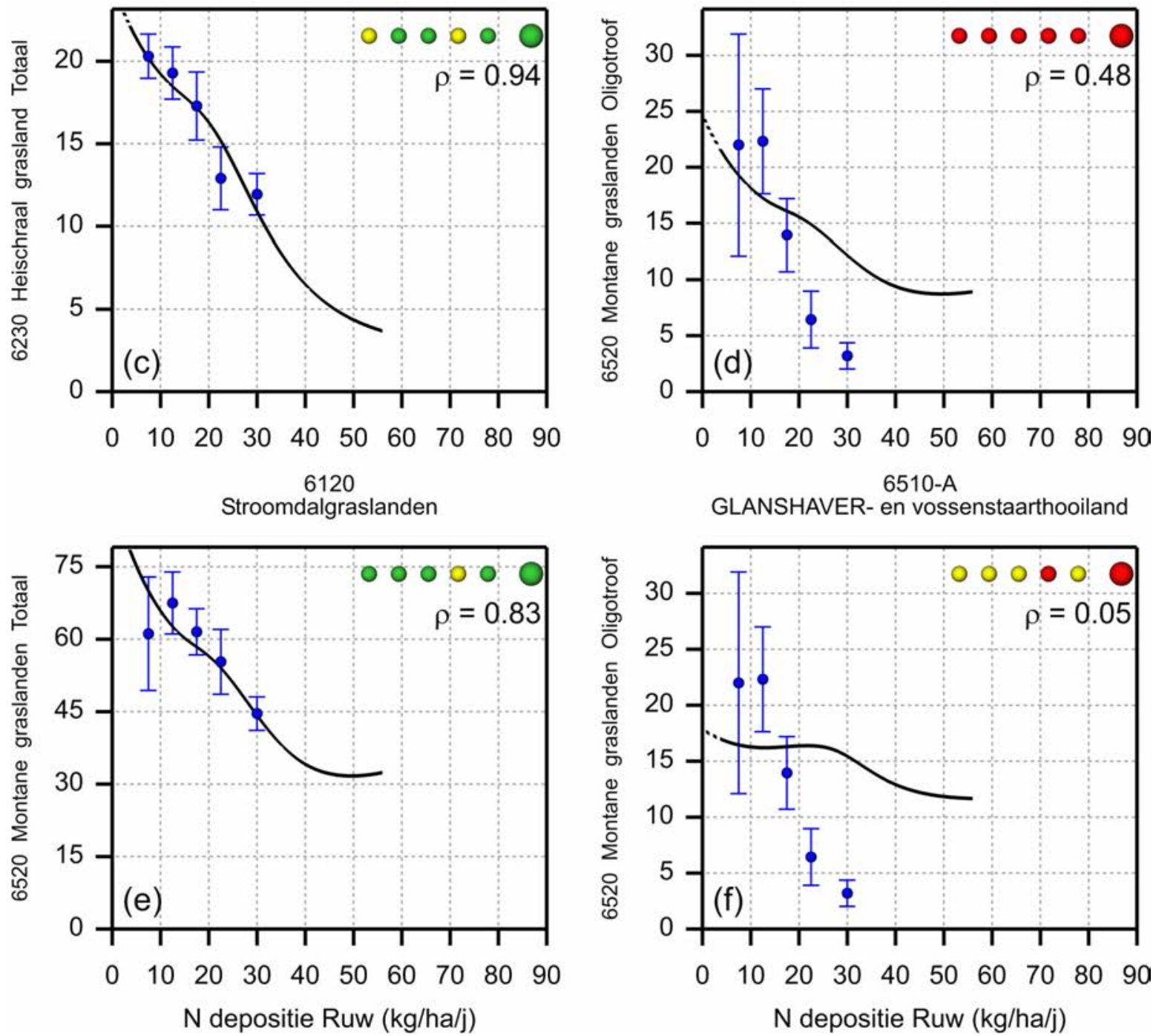

Figuur 63 Vergelijking, per habitattype, tussen empirische effecten (inclusief 95\%betrouwbaarheidsinterval, blauw) van stikstofdepositie op het aantal soorten en de vermenigvuldigde statistische responscurve. De kleurcoderingen geven de mate van overeenstemming aan zoals gegeven door een vijftal experts in Tabel 14 (groen=goed, geel=matig, rood=slecht), waarbij het eindoordeel groter is weergegeven. De $\rho$ geeft Lin's correlation coefficient of concordance tussen de empirische data en de responscurve. 

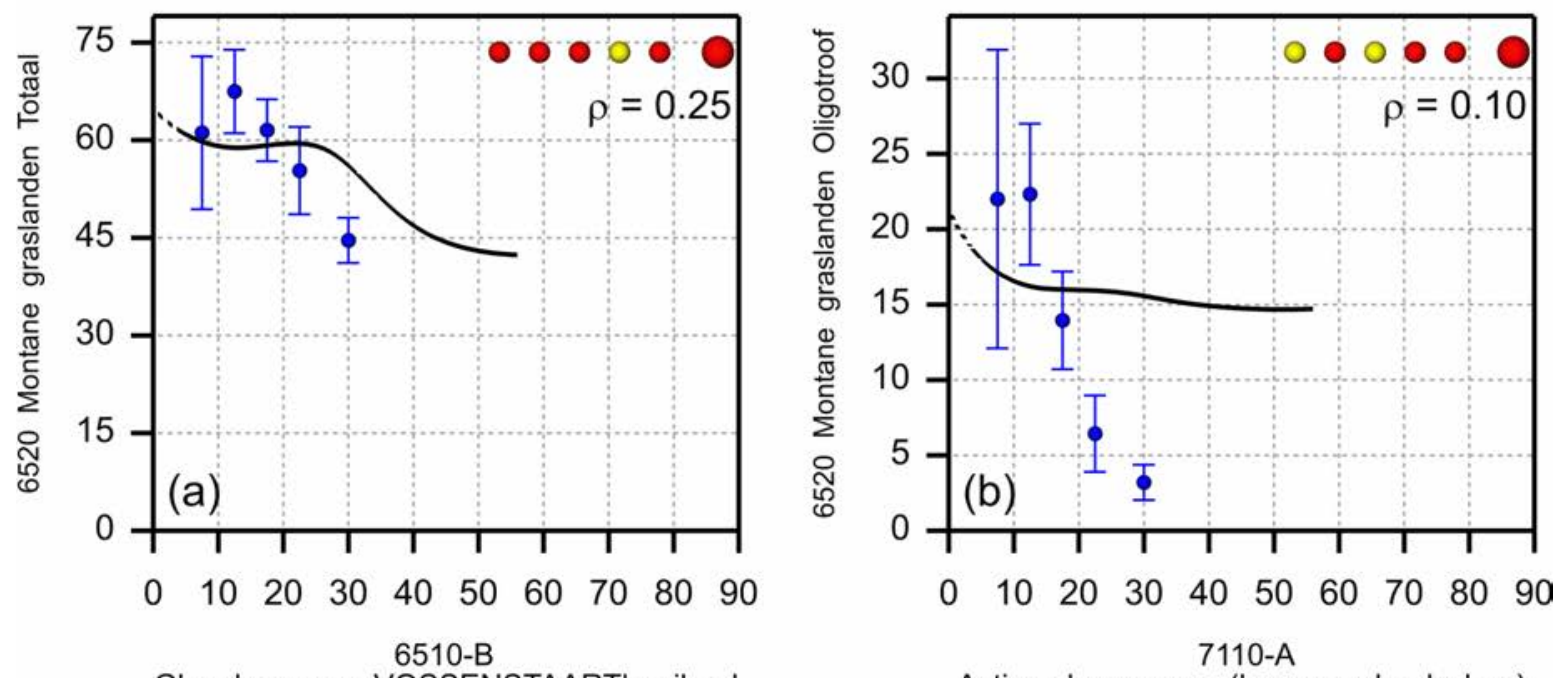

Glanshaver- en VOSSENSTAARThooiland
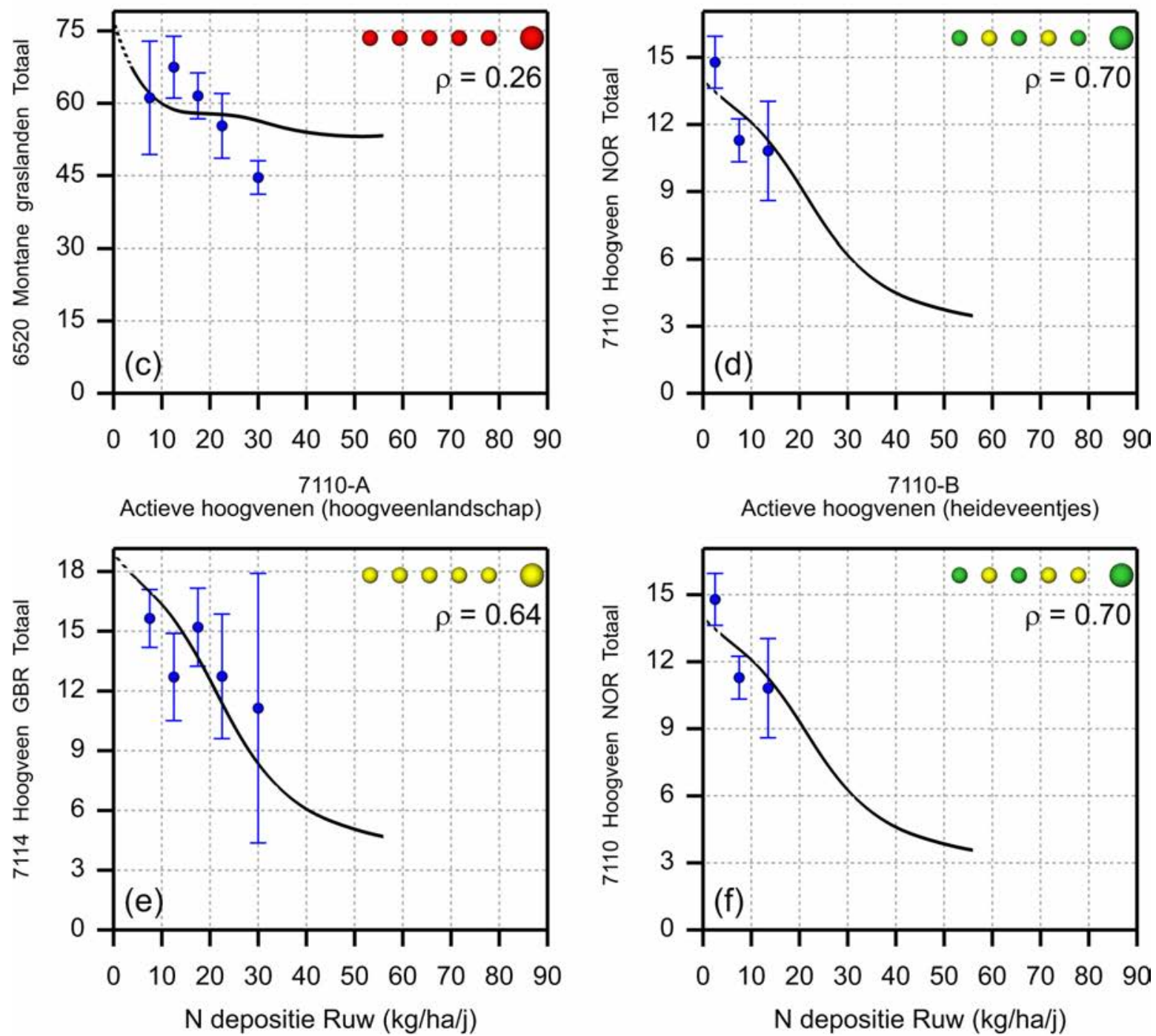

Figuur 64 Vergelijking, per habitattype, tussen empirische effecten (inclusief 95\%betrouwbaarheidsinterval, blauw) van stikstofdepositie op het aantal soorten en de vermenigvuldigde statistische responscurve. De kleurcoderingen geven de mate van overeenstemming aan zoals gegeven door een vijftal experts in Tabel 14 (groen=goed, geel=matig, rood=slecht), waarbij het eindoordeel groter is weergegeven. De $\rho$ geeft Lin's correlation coefficient of concordance tussen de empirische data en de responscurve. 
7110-B

Actieve hoogvenen (heideveentjes)

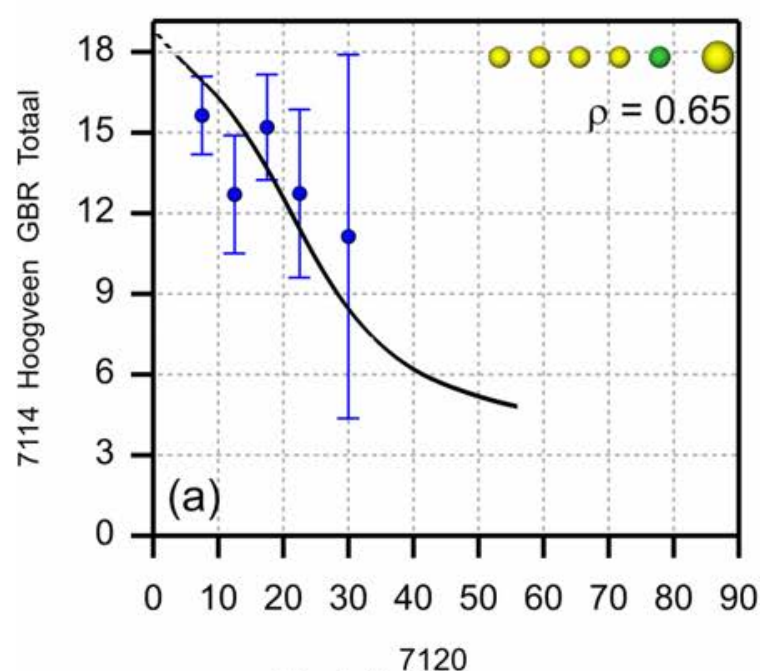

Herstellende hoogvenen
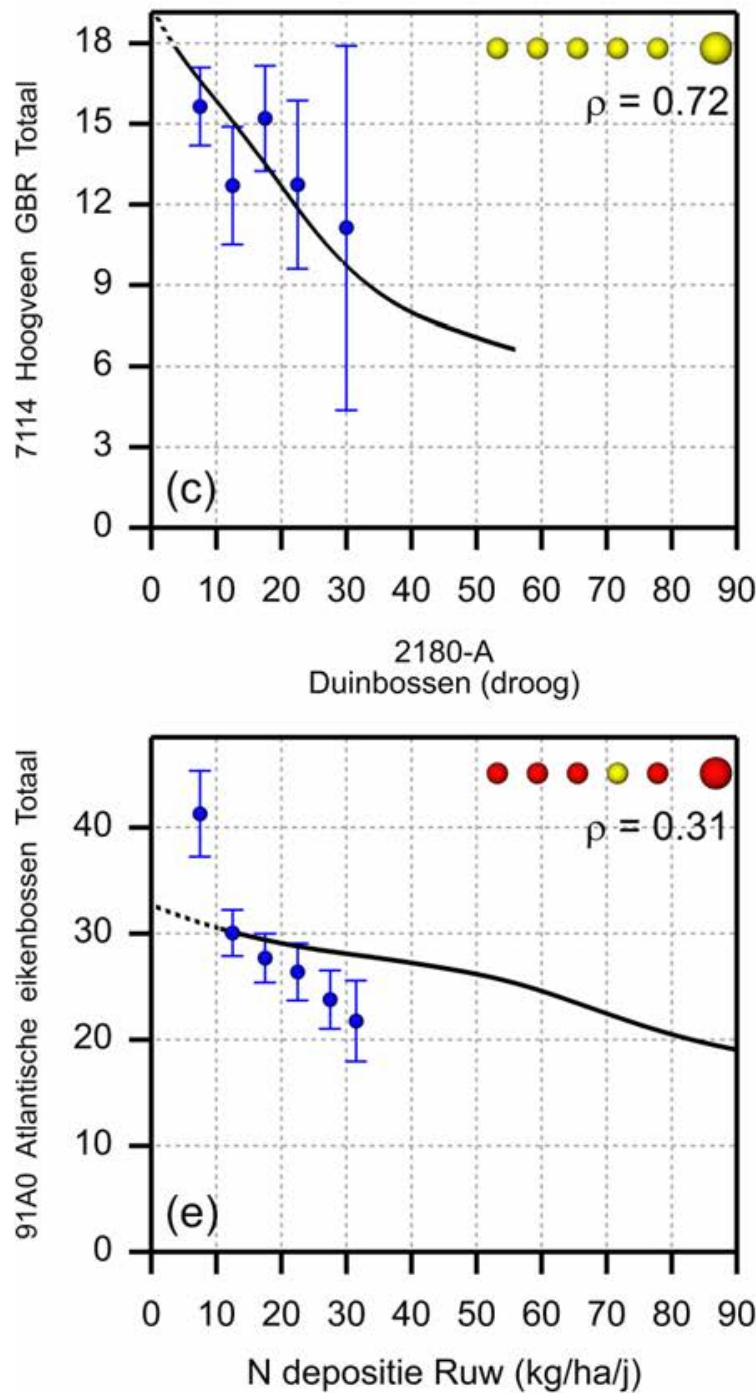

7120

Herstellende hoogvenen

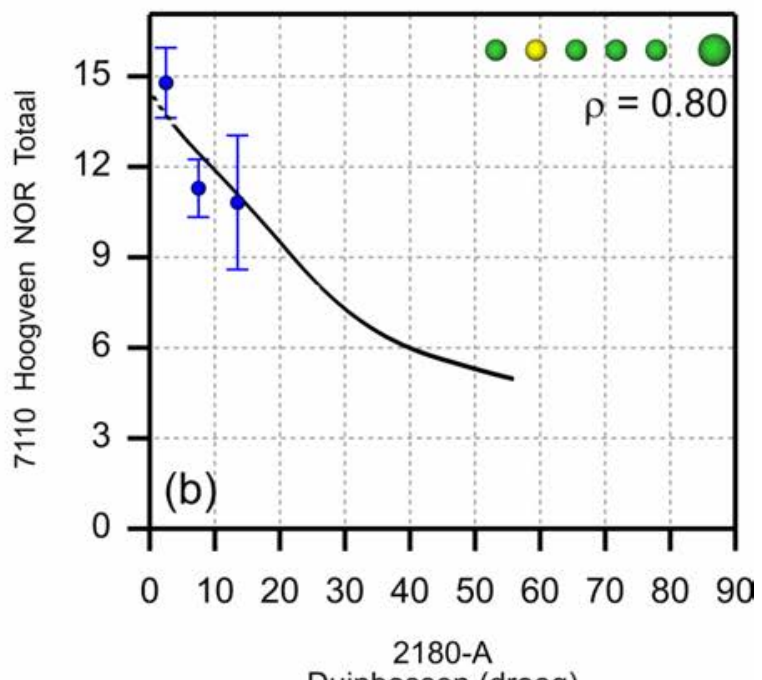

Duinbossen (droog)
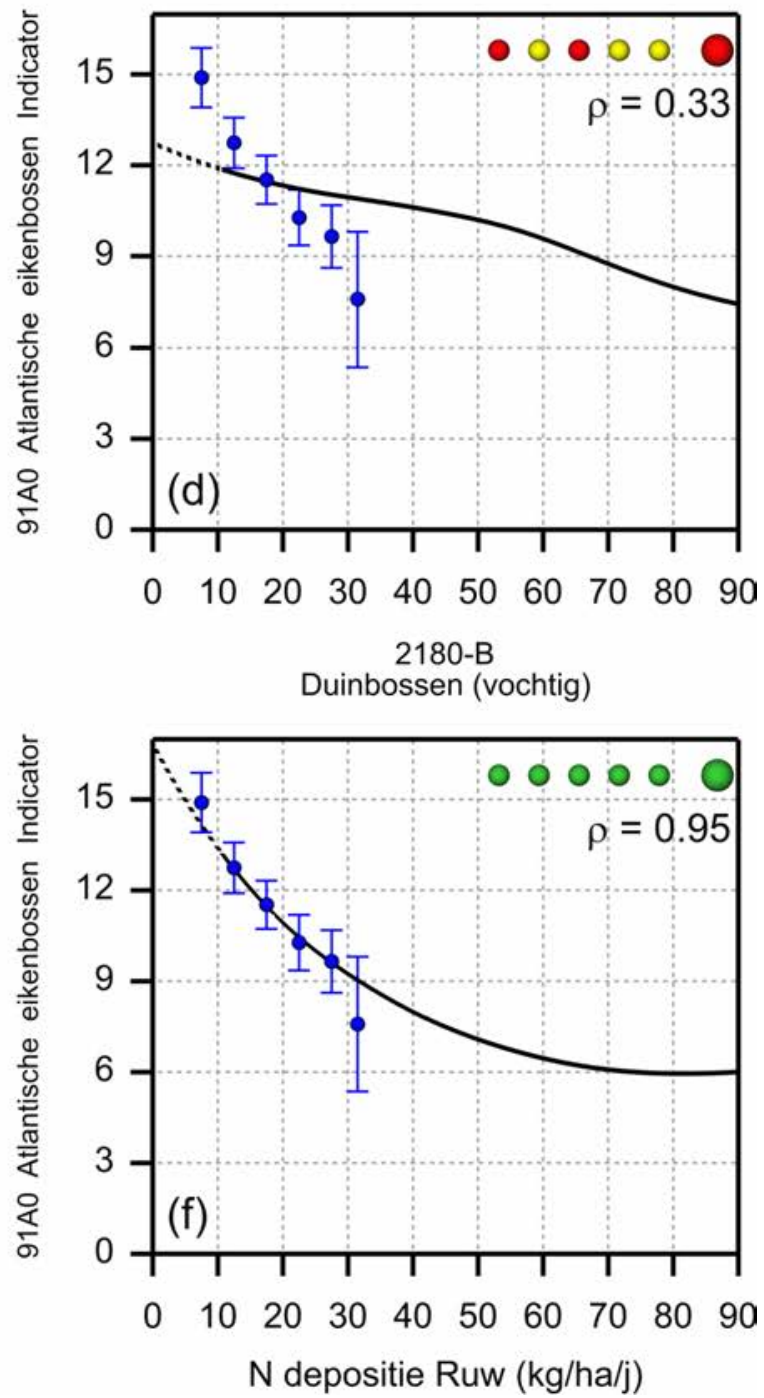

Figuur 65 Vergelijking, per habitattype, tussen empirische effecten (inclusief 95\%betrouwbaarheidsinterval, blauw) van stikstofdepositie op het aantal soorten en de vermenigvuldigde statistische responscurve. De kleurcoderingen geven de mate van overeenstemming aan zoals gegeven door een vijftal experts in Tabel 14 (groen=goed, geel=matig, rood=slecht), waarbij het eindoordeel groter is weergegeven. De $\rho$ geeft Lin's correlation coefficient of concordance tussen de empirische data en de responscurve. 
2180-B

Duinbossen (vochtig)

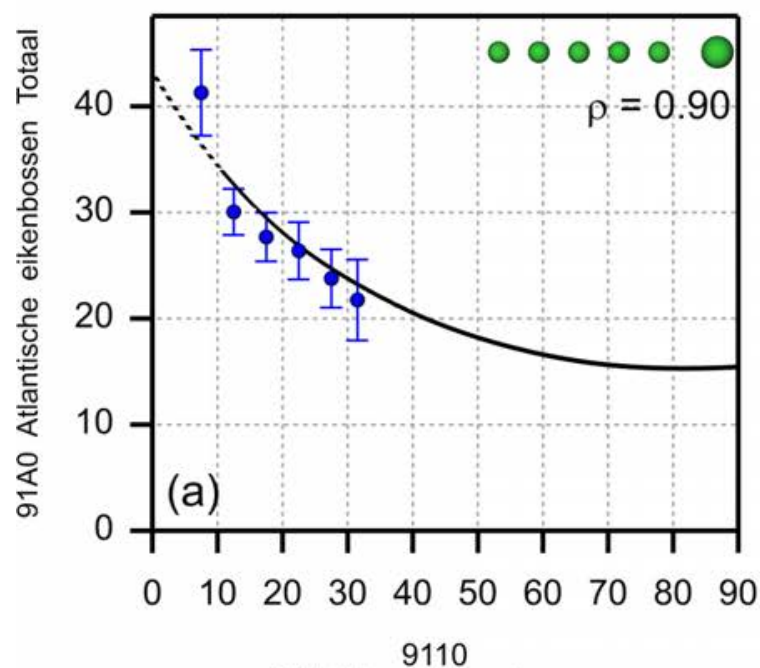

Veldbies-beukenbossen
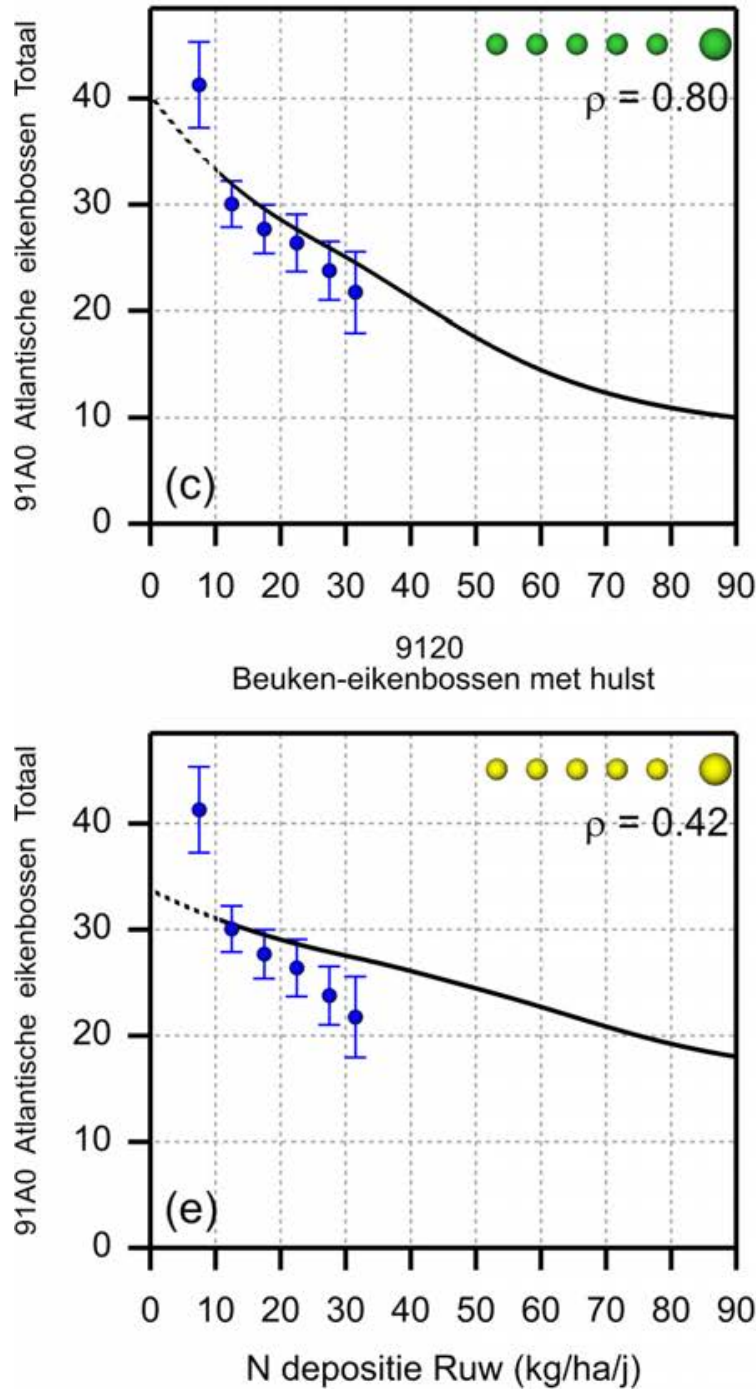

9110

Veldbies-beukenbossen

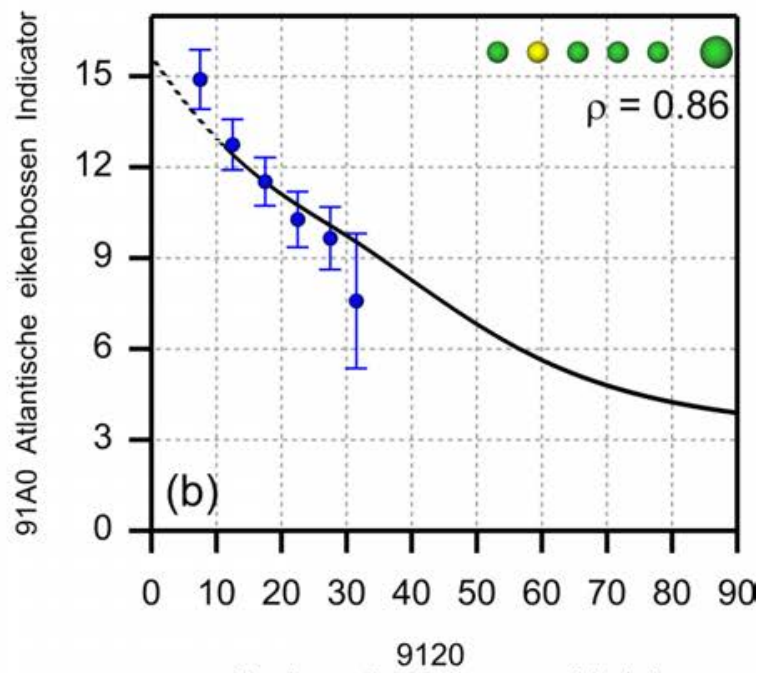

Beuken-eikenbossen met hulst

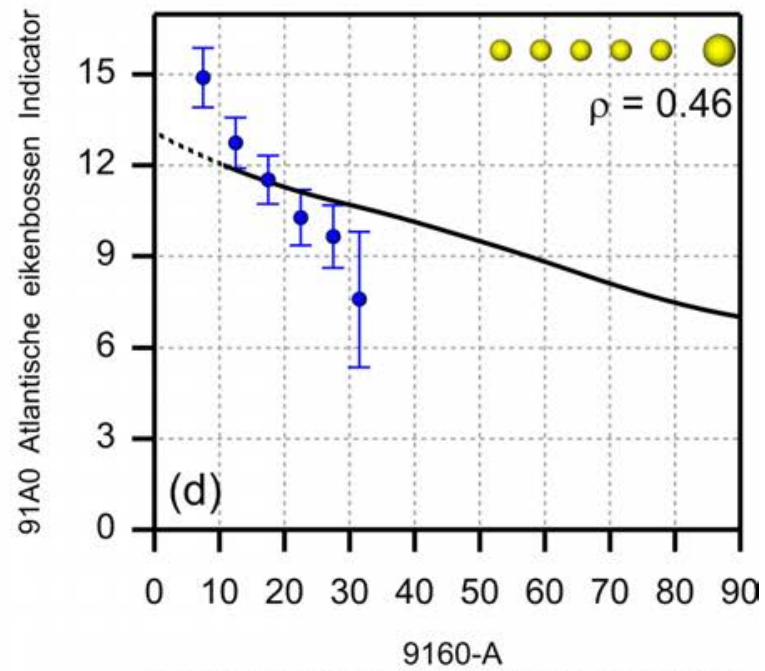

Eiken-haagbeukbos (hogere zandgronden)

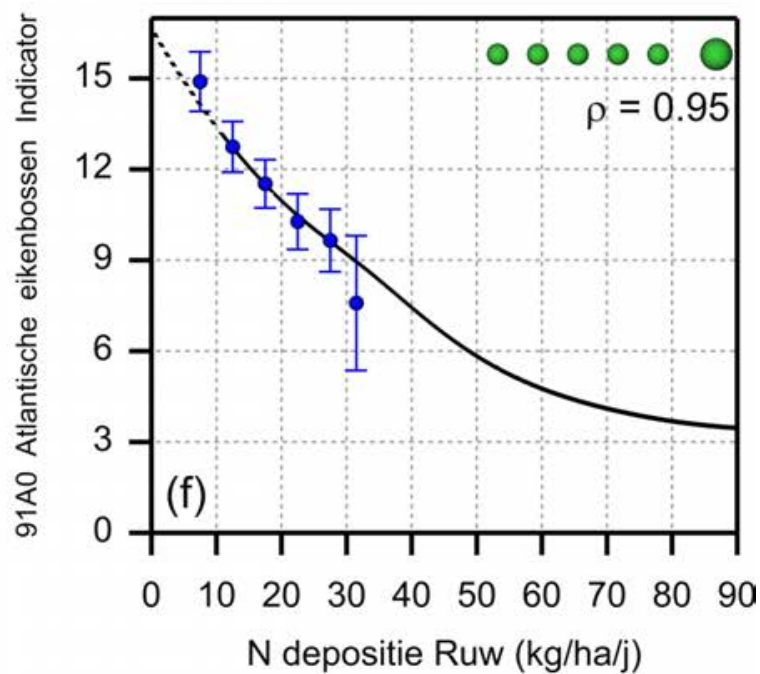

Figuur 66 Vergelijking, per habitattype, tussen empirische effecten (inclusief 95\%betrouwbaarheidsinterval, blauw) van stikstofdepositie op het aantal soorten en de vermenigvuldigde statistische responscurve. De kleurcoderingen geven de mate van overeenstemming aan zoals gegeven door een vijftal experts in Tabel 14 (groen=goed, geel=matig, rood=slecht), waarbij het eindoordeel groter is weergegeven. De $\rho$ geeft Lin's correlation coefficient of concordance tussen de empirische data en de responscurve. 
9160-A

Eiken-haagbeukbos (hogere zandgronden)

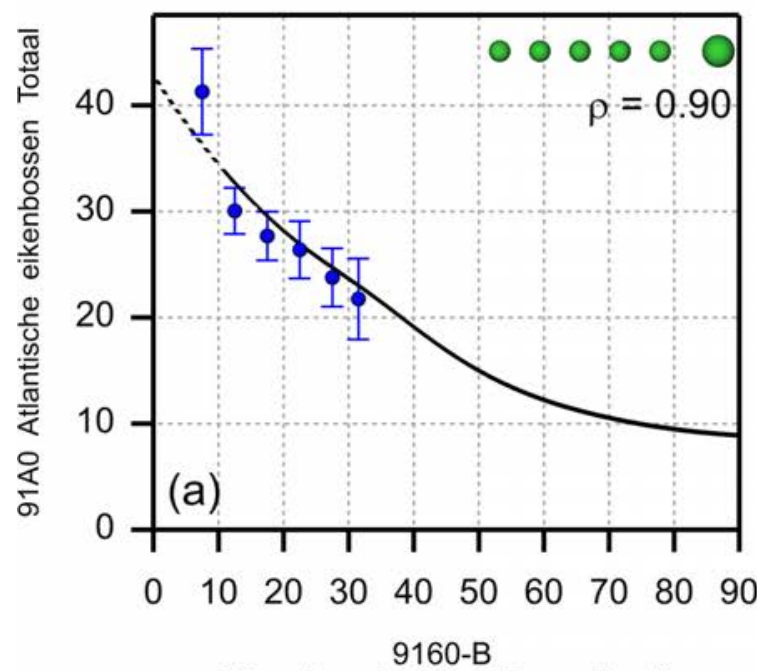

Eiken-haagbeukbos (heuvelland)

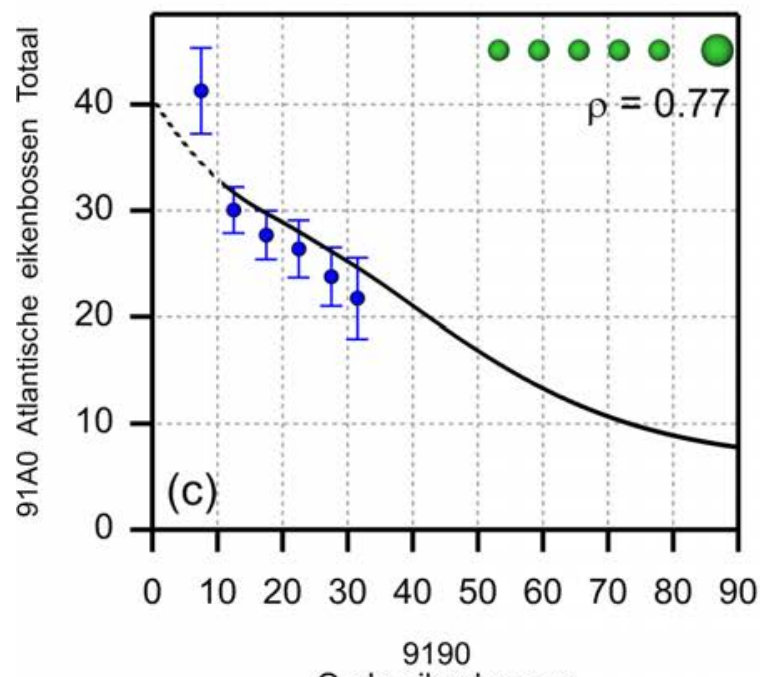

Oude eikenbossen

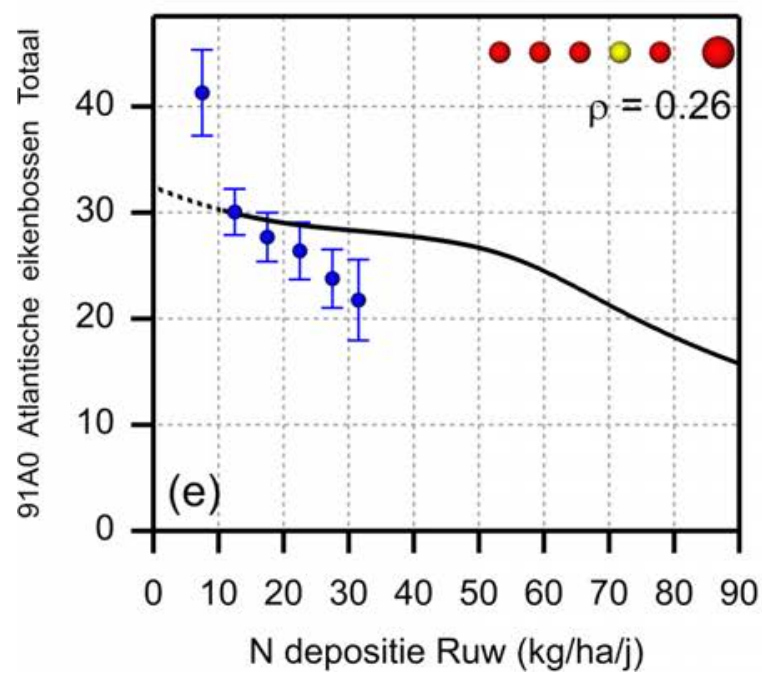

9160-B

Eiken-haagbeukbos (heuvelland)

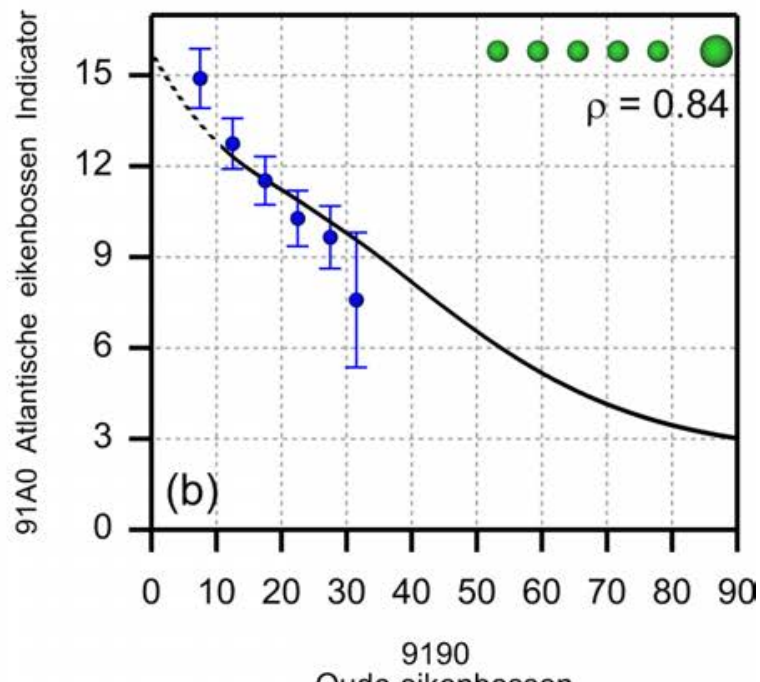

Oude eikenbossen

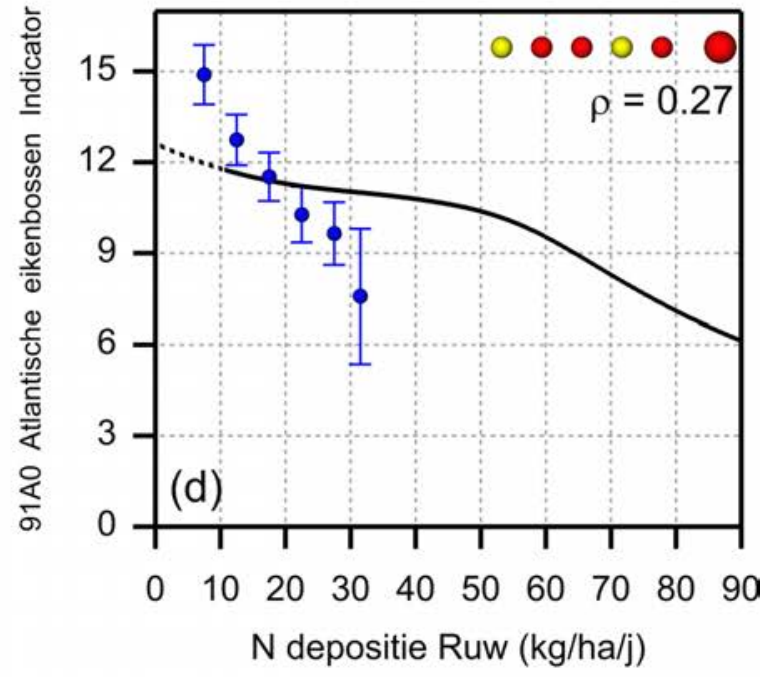

Figuur 67 Vergelijking, per habitattype, tussen empirische effecten (inclusief 95\%betrouwbaarheidsinterval, blauw) van stikstofdepositie op het aantal soorten en de vermenigvuldigde statistische responscurve. De kleurcoderingen geven de mate van overeenstemming aan zoals gegeven door een vijftal experts in Tabel 14 (groen=goed, geel=matig, rood=slecht), waarbij het eindoordeel groter is weergegeven. De $\rho$ geeft Lin's correlation coefficient of concordance tussen de empirische data en de responscurve. 


\section{C.4 Beoordeling van de integratie}

De vergelijking tussen responscurven en empirische data laat uiteenlopende resultaten zien. In 25 gevallen is de overeenkomst goed, in 5 gevallen matig en in 11 gevallen slecht (Tabel 14). De matig en slecht scorende combinaties worden hieronder verder besproken.

Voor alle combinaties met de empirische waarden voor de Montane graslanden is de score matig tot slecht, behalve voor de combinatie met stroomdalgraslanden en dan alleen voor de empirische waarden van de deelverzameling van oligotrofe soorten. Een mogelijke verklaring hiervoor is dat dit type, dat in Nederland niet voorkomt, niet goed past bij de geselecteerde Nederlandse habitattypen. Daar staat tegenover dat de curven van de Nederlandse typen die matig of slecht scoren ook een niet verwacht beeld geven. De Glanshaver- en vossenstaarthooilanden hebben responscurven die nauwelijks reageren op de stikstofdepositie. Alleen het subtype glanshaver vertoont enige overeenkomst met het totaalaantal soorten voor montane graslanden. De geringe of afwezige daling van de responscurve voor de Glanshaver- en Grote vossenstaarthooilandtypen zijn als slecht aangemerkt in paragraaf B.2.3, en dat wordt min of meer bevestigd door de vergelijking met empirische data. Voor het subtype, Glanshaver- en Grote vossenstaarthooilanden A (glanshaver), is verder onderzocht waarom de responscurve niet aan de verwachting voldoet. Voor dit type zijn 36 kwalificerende soorten geselecteerd. Daarvan geven er 14 een daling te zien bij hogere depositie, zijn 11 soorten min of meer indifferent over het gehele traject (inclusief 6 soorten die een optimumcurve hebben) en 11 soorten die toenemen bij hogere depositie. Tabel 13 geeft de soorten per categorie. Alle soorten die toenemen, zijn soorten die door de FLORON-verspreidingsatlas (www.verspreidingsatlas. $\mathrm{nl}$ ) als onveranderd of toegenomen zijn gecategoriseerd (op basis van de gegevens van de Rode Lijst). Het zijn zeer algemene soorten, waarvan het geen verbazing wekt dat ze toenemen bij een toenemende bemesting of stikstofdepositie. Van de soorten die afnemen, staan er vier op de Rode Lijst en hebben er vier een negatieve trend sinds 1950 zonder al zeldzaam te zijn geworden (met 25-50\% afname; Groot streepzaad, Echte kruisdistel, Gewone margriet en Goudhaver). De andere soorten vertonen volgens FLORON geen negatieve trend. Binnen de groep van soorten met een dalende responscurve bevinden zich overigens drie soorten waarvoor dat niet werd verwacht: Jacobskruiskruid (toenemend), Veldlathyrus (voedselrijke omstandigheden) en Bermooievaarsbek (een sterk toegenomen soort uit zuidelijke streken). Van de soorten die niet echt duidelijk reageren of die eerst toenemen en dan weer afnemen ('neutrale curve'), zoals Peen, Smalle weegbree, Knoopkruid en Glad walstro, zou de geschatte responscurve kunnen kloppen. De (zeer) algemene soorten met een stijgende curve, ten slotte, drukken zo'n groot stempel op de responscurve van het habitat(sub)type dat de responscurve voor het habitattype nauwelijks daalt met toenemende stikstofdepositie. Een logisch resultaat op basis van de soortensamenstelling en de reactie van die soorten, maar niet overeenkomend met de empirische gegevens. De verschillen worden dus waarschijnlijk veroorzaakt door de samenstelling van de soortenlijst: een groot deel van de geselecteerde soorten komt ook buiten het habitattype voor, vooral onder voedselrijke omstandigheden. Ze komen inderdaad ook frequent voor in het habitattype, maar behoren daar niet tot de soorten die kenmerkend zijn voor de goede kwaliteit. Een deel van de soorten die een stijgende curve laat zien, behoort zelfs tot de (type-eigen) verdringingssoorten.

Deze analyse geeft aan dat het resultaat van de gebruikte methode om kwaliteitssoorten te selecteren te weinig overeenkomt met de definitie die voor deze soorten was opgesteld. Die definitie luidt: soorten die diagnostisch zijn voor de plantengemeenschappen met een goede kwaliteit van een bepaald habitat(sub)type en die dus het verschil aangeven met plantengemeenschappen die niet behoren tot de goede kwaliteit van het habitat(sub)type). Deze conclusie geldt in ieder geval voor het onderzochte habitat(sub)type 6510A, maar geldt waarschijnlijk ook voor meer typen. 
Tabel 13 Soorten die een dalende, een min of meer neutrale en een stijgende responscurve voor stikstofdepositie geven voor Glanshaver- en vossenstaarthooilanden (glanshaver, 6510A), een type waarvan de responscurve als slecht is beoordeeld (R.L. = Rode Lijst).

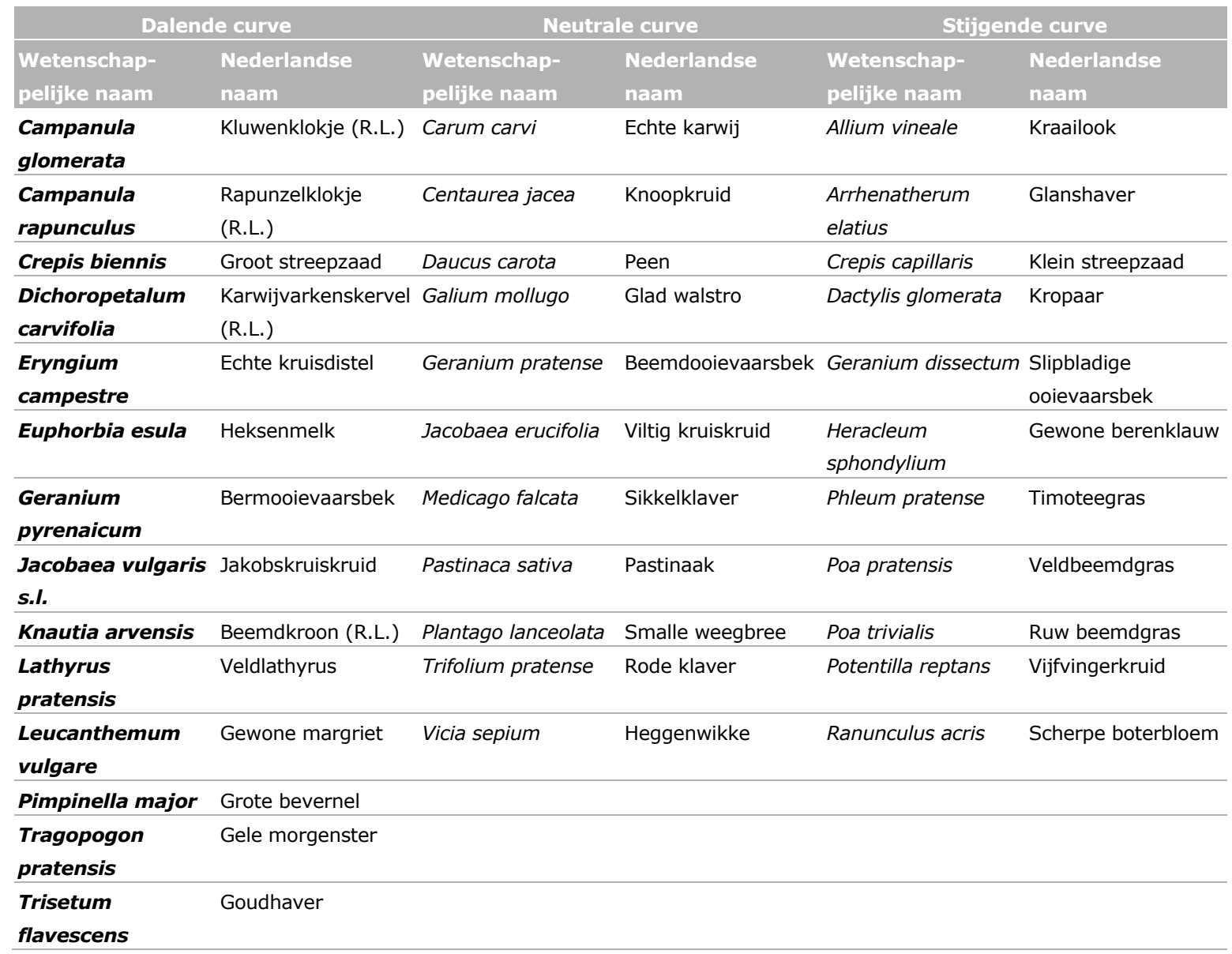

Wanneer de hoogveentypen vergeleken worden met de (beperkte) Noorse dataset, geven de responscurven eenzelfde beeld als de empirische depositiewaarden: een dalende trend. Voor de empirische data uit het Verenigd Koninkrijk is het beeld anders. Zoals hierboven al werd vermeld, werd er bij die dataset geen significant verband aangetoond tussen de soortenrijkdom en de verschillende depositieniveaus. Een matige overeenkomst is dan ook logisch.

De overige matige en slechte overeenkomsten tussen empirische data en responscurven gelden voor drie van de bostypen die zijn vergeleken met de Atlantische eikenbossen. Ook hier geldt dat de responscurven nauwelijks tot geen dalende lijn vertonen als gevolg van stikstofdepositie, terwijl de empirische waarden dat wel doen. De responscurven voor beide typen zijn als slecht aangemerkt in paragraaf B.2.3. Dat oordeel wordt bevestigd door de vergelijking met empirische data. 
Tabel 14 Beoordeling van de responscurven per habitattype op basis van de empirische dosiseffectrelaties. Hierin is $\rho$ Lin's correlation coëfficiënt of concordance. De experts (vijf in getal) hebben de overeenkomst beoordeeld in goed ( $G$, groen), matig ( $M$, geel) en slecht ( $S$, rood). De kolom Eind geeft het eindoordeel. Het eindoordeel is gebaseerd op Lin's coëfficiënt en de experts, waarbij bij twijfel Lin's coëfficiënt de doorslag geeft als onafhankelijke objectieve maat. De tabel geeft een overzicht van de in de figuren al gepresenteerde gegevens, er staan geen nieuwe gegevens in.

\begin{tabular}{|c|c|c|c|c|c|c|c|c|c|}
\hline Empirische data & Respons & Responscurve habitattype & Lin's p & & . & $m$ & xpe & & Eind \\
\hline habitattype & Code & Habitattype & & 1 & 2 & 3 & 4 & 5 & \\
\hline Grijze duinen & $2130-A$ & Grijze duinen (kalkrijk) & 0,69 & M & G & G & M & G & G \\
\hline Grijze duinen & 2130-B & Grijze duinen (kalkarm) & 0,72 & G & G & G & G & G & G \\
\hline Grijze duinen & $2130-C$ & Grijze duinen (heischraal) & 0,80 & M & G & G & M & G & G \\
\hline Droge heiden & $2140-B$ & Duinheiden met kraaihei (droog) & 0,93 & G & G & G & G & G & G \\
\hline Droge heiden & 2150 & Duinheide met struikhei & 0,97 & G & G & G & G & G & G \\
\hline Droge heiden & 2310 & Stuifzandheiden met struikhei & 0,96 & G & G & G & G & G & G \\
\hline Droge heiden & 4030 & Droge heiden & 0,92 & G & G & G & G & G & G \\
\hline $\begin{array}{l}\text { Kalkgraslanden BEGIN } \\
\text { Mesobromion }\end{array}$ & 6110 & Pionierbegroeiingen op rotsbodem & 0,81 & G & M & G & G & M & G \\
\hline Kalkgraslanden BEGIN & 6110 & Pionierbegroeiingen op rotsbodem & 0,18 & & & $\mathrm{~s}$ & & & s \\
\hline Kalkgraslanden (6210) UK & 6110 & Pionierbegroeiingen op rotsbodem & 0,66 & G & M & G & G & M & G \\
\hline $\begin{array}{l}\text { Kalkgrasland (6210) BEGIN } \\
\text { Mesobromion }\end{array}$ & 6210 & Kalkgraslanden & 0,63 & G & M & G & G & G & G \\
\hline Kalkgrasland (6210) BEGIN & 6210 & Kalkgraslanden & 0,29 & & & G & & & s \\
\hline Kalkgrasland VK & 6210 & Kalkgraslanden & 0,60 & G & M & G & G & M & G \\
\hline Heischraal grasland kruiden & 6230 & Heischrale graslanden & 0,80 & G & G & G & M & G & G \\
\hline Heischraal grasland totaal & 6230 & Heischrale graslanden & 0,94 & M & G & G & M & G & G \\
\hline $\begin{array}{l}\text { Montane graslanden } \\
\text { Oligotrofe soorten }\end{array}$ & 6120 & Stroomdalgraslanden & 0,48 & s & S & $\mathrm{S}$ & S & S & S \\
\hline Montane graslanden totaal & 6120 & Stroomdalgraslanden & 0,83 & G & G & G & M & G & G \\
\hline $\begin{array}{l}\text { Montane graslanden } \\
\text { Oligotrofe soorten }\end{array}$ & $6510-A$ & $\begin{array}{l}\text { Glanshaver- en vossenstaart-hooilanden } \\
\text { (glanshaver) }\end{array}$ & 0,05 & M & M & M & $\mathrm{S}$ & M & S \\
\hline Montane graslanden totaal & $6510-A$ & $\begin{array}{l}\text { Glanshaver- en vossenstaart-hooilanden } \\
\text { (glanshaver) }\end{array}$ & 0,25 & $\mathrm{~S}$ & S & $\mathrm{S}$ & M & $\mathrm{S}$ & $\mathrm{s}$ \\
\hline $\begin{array}{l}\text { Montane graslanden } \\
\text { Oligotrofe soorten }\end{array}$ & $6510-B$ & $\begin{array}{l}\text { Glanshaver- en vossenstaart-hooilanden } \\
\text { (grote vossenstaart) }\end{array}$ & 0,10 & M & $\mathrm{s}$ & M & S & S & $\mathrm{s}$ \\
\hline Montane graslanden totaal & $6510-B$ & $\begin{array}{l}\text { Glanshaver- en vossenstaart-hooilanden } \\
\text { (grote vossenstaart) }\end{array}$ & 0,26 & $\mathrm{~s}$ & s & $\mathrm{S}$ & S & $\mathrm{S}$ & S \\
\hline Hoogvenen Noorwegen & $7110-A$ & $\begin{array}{l}\text { Actieve hoogvenen } \\
\text { (hoogveenlandschap) }\end{array}$ & 0,70 & G & M & G & M & G & G \\
\hline Hoogvenen VK & $7110-A$ & $\begin{array}{l}\text { Actieve hoogvenen } \\
\text { (hoogveenlandschap) }\end{array}$ & 0,64 & M & M & M & M & M & M \\
\hline Hoogvenen Noorwegen & 7110-B & Actieve hoogvenen (heideveentjes) & 0,70 & G & M & G & M & M & G \\
\hline Hoogvenen VK & $7110-B$ & Actieve hoogvenen (heideveentjes) & 0,65 & M & M & M & M & G & M \\
\hline Hoogvenen Noorwegen & 7120 & Herstellende hoogvenen & 0,80 & G & M & G & G & G & G \\
\hline Hoogveen VK & 7120 & Herstellende hoogvenen & 0,72 & M & M & M & M & M & M \\
\hline $\begin{array}{l}\text { Atlantische eikenbossen } \\
\text { indicatorsoorten }\end{array}$ & $2180-A$ & Duinbossen (droog) & 0,33 & $\mathrm{~s}$ & M & $\mathrm{S}$ & M & M & $\mathrm{S}$ \\
\hline $\begin{array}{l}\text { Atlantische eikenbossen } \\
\text { totaal }\end{array}$ & $2180-A$ & Duinbossen (droog) & 0,31 & s & s & $\mathrm{S}$ & M & $\mathrm{s}$ & S \\
\hline $\begin{array}{l}\text { Atlantische eikenbossen } \\
\text { indicatorsoorten }\end{array}$ & $2180-B$ & Duinbossen (vochtig) & 0,95 & G & G & G & G & G & G \\
\hline $\begin{array}{l}\text { Atlantische eikenbossen } \\
\text { totaal }\end{array}$ & $2180-B$ & Duinbossen (vochtig) & 0,90 & G & G & G & G & G & G \\
\hline $\begin{array}{l}\text { Atlantische eikenbossen } \\
\text { indicatorsoorten }\end{array}$ & 9110 & Veldbies-beukenbossen & 0,86 & G & M & G & G & G & G \\
\hline $\begin{array}{l}\text { Atlantische eikenbossen } \\
\text { totaal }\end{array}$ & 9110 & Veldbies-beukenbossen & 0,80 & G & G & G & G & G & G \\
\hline $\begin{array}{l}\text { Atlantische eikenbossen } \\
\text { indicatorsoorten }\end{array}$ & 9120 & Beuken-eikenbossen met hulst & 0,46 & M & M & M & M & M & M \\
\hline
\end{tabular}




\begin{tabular}{|c|c|c|c|c|c|c|c|c|c|}
\hline \multirow{2}{*}{$\begin{array}{l}\text { Empirische data } \\
\text { vegetatietype } \\
\text { habitattype }\end{array}$} & \multirow{2}{*}{$\begin{array}{l}\text { Respons } \\
\text { curve } \\
\text { Code }\end{array}$} & \multirow{2}{*}{$\begin{array}{l}\text { Responscurve habitattype } \\
\text { Habitattype }\end{array}$} & \multirow[t]{2}{*}{ Lin's p } & \multicolumn{3}{|c|}{ Beoordeling } & \multicolumn{2}{|c|}{ Experts } & \multirow[t]{2}{*}{ Eind } \\
\hline & & & & 1 & 2 & 3 & 4 & 5 & \\
\hline $\begin{array}{l}\text { Atlantische eikenbossen } \\
\text { totaal }\end{array}$ & 9120 & Beuken-eikenbossen met hulst & 0,42 & M & M & M & M & M & M \\
\hline $\begin{array}{l}\text { Atlantische eikenbossen } \\
\text { indicatorsoorten }\end{array}$ & $9160-A$ & $\begin{array}{l}\text { Eiken-haagbeukenbossen (hogere } \\
\text { zandgronden) }\end{array}$ & 0,95 & G & G & G & G & G & G \\
\hline $\begin{array}{l}\text { Atlantische eikenbossen } \\
\text { totaal }\end{array}$ & $9160-A$ & $\begin{array}{l}\text { Eiken-haagbeukenbossen (hogere } \\
\text { zandgronden) }\end{array}$ & 0,90 & G & G & G & G & G & G \\
\hline $\begin{array}{l}\text { Atlantische eikenbossen } \\
\text { indicatorsoorten }\end{array}$ & $9160-B$ & Eiken-haagbeukenbossen (heuvelland) & 0,84 & G & G & G & G & G & G \\
\hline $\begin{array}{l}\text { Atlantische eikenbossen } \\
\text { totaal }\end{array}$ & $9160-B$ & Eiken-haagbeukenbossen (heuvelland) & 0.77 & G & G & G & G & G & G \\
\hline $\begin{array}{l}\text { Atlantische eikenbossen } \\
\text { indicatorsoorten }\end{array}$ & 9190 & Oude eikenbossen & 0,27 & M & S & $\mathrm{S}$ & M & S & $\mathrm{S}$ \\
\hline $\begin{array}{l}\text { Atlantische eikenbossen } \\
\text { totaal }\end{array}$ & 9190 & Oude eikenbossen & 0,26 & $\mathrm{~S}$ & S & $\mathrm{s}$ & M & S & $\mathrm{S}$ \\
\hline
\end{tabular}




\section{Literatuur}

Amann M, Bertok I, Borken-Kleefeld J, Cofala J, Heyes C, Höglund-Isaksson L, Klimont Z, Nguyen B, Posch M, Rafaj P, Sandler R, Schöpp W, Wagner F, Winiwarter W, 2011. Cost-effective control of air quality and greenhouse gases in Europe: Modeling and policy applications. Environmental Modelling \& Software 26(12): 1489-1501; DOI: 10.1016/j.envsoft.2011.07.012

Anonymus. 2014. Leeswijzer Natura 2000 profielen. Geheel herziene versie september 2014. Ten behoeve van de profielen behorende bij de aanwijzing van de Natura 2000-gebieden in de EEZ. Programmadirectie Natura 2000, Ministerie van Economische Zaken, Den Haag.

Armitage, H.F., A. J. Britton, R. van der Wal \& S. J. Woodin (2014). The relative importance of nitrogen deposition as a driver of Racomitrium heath species composition and richness across Europe. Biological Conservation 171, 224-231.

Berdowski, J.J.M. 1987. Transition from heathland to grassland initiated by the heather beetle. Vegetatio 72: 167-173. https://doi.org/10.1007/BF00039838.

Bobbink R. \& J.P. Hettelingh (eds.) (2011). Review and revision of empirical critical loads and doseresponse relationships. Coordination Centre for Effects, National Institute for Public Health and the Environment (RIVM), RIVM report 680359002/2011 (244 pp).

Chytrý, M., Hennekens. S.M., Jiménez-Alfaro B., ... \& Yamalov, S. 1996. European Vegetation Archive (EVA): an integrated database of European vegetation plots. Applied Vegetation Science 19: 173.180. https://doi.org/10.1111/avsc.12191.

Chytrý, M., Tichý, L., Hennekens. S.M., ... \& Schaminée, J.H.J. 2020. EUNIS Habitat Classification: Expert system, characteristic species combinations and distribution maps of European habitats. Applied Vegetation Science 28: 648 - 675.

Caporn, S.J.M., Carroll, J.A., Dise, N.B., Payne, R.J. (2014). Impacts and indicators of nitrogen deposition in moorlands: results from a national pollution gradient study. Ecolological Indicators 45, 227-234.

Clark, C.M., Simkin, S.M., Allen, E.B., ... \& Waller, D.M. 2019. Potential vulnerability of 348 herbaceous species to atmospheric deposition of nitrogen and sulfur in the United States. Nat. Plants 5, 697705. https://doi.org/10.1038/s41477-019-0442-8.

Cornes, R., van der Schrier, G., van den Besselaar, E.J.M. and Jones, PD. 2018: An ensemble Version of the E-Obs Temeprature and Precipitation Datasets, J. Geophys. Res. Atmos. 123.

Dorland, E., R. Bobbink, S. Rotthier, \& M.B. Soons (2011). Heischrale graslanden: nu en in de toekomst bedreigd door overmaat aan stikstof! De Levende Natuur, 112(6), 220-224.

During, H.J. \& J.H. Willems (1986). The Impoverishment of the bryophyte and lichen flora of the Dutch chalk grasslands in the thirty years 1953-1983. Biological Conservation 36, 143-158.

EUNIS. www. eunis.eea.europa.eu last visited 12/12/2020

Field, C.D., Dise, N.B., Payne, R.J., Britton, A.J., Emmett, B.A., Helliwell, R.C., Hughes, S., Jones, L., Lees, S., Leake, J.R., Leith, I.D., Phoenix, G.K., Power, S.A., Sheppard, L.J., Southon, G.E., Stevens, C.J., Caporn, S.J.M. (2014). The role of nitrogen deposition in widespread plant community change across semi-natural habitats. Ecosystems 17 (5), 864-877.

Fremstad, E., Paal, J. \& Möls, T. 2005. Impacts of increased nitrogen supply on Norwegian lichen-rich alpine communities: A 10-year experiment. Journal of Ecology 93: 471-481.

Hastie, T.J. \& Tinshirani, R.J. 1990. Generalized Additive Models. Chapman and Hall. London.

Hennekens, S.M., Ozinga, W.A. \& Schaminée, J.H.J. 2017. BioScore 3 - Plants. Background and preprocessing of distribution data. Statutory Research Tasks Unit for Nature \& the Environment (WOT Natuur \& Milieu), WOt-technical report 106.

Henry, J., Aherne, J., 2014. Nitrogen deposition and exceedance of critical loads for nutrient nitrogen in Irish grasslands. Sci. Total Environ. 470-471, 216-223.

Jokerud, M. (2012). Impact of Nitrogen Deposition on Species Richness and Species Composition of Ombrotrophic Mires in Western Norway. Master Thesis, Department of Biology, University of Bergen, Norway. 
Levy, P.E., Smith, R.I., Tang, Y.S., Stedman, J.R. (2020). Deposition of nitrogen, sulphur and base cations to the UK (1986-2012). NERC Environmental Information Data Centre. (Dataset). https://doi.org/10.5285/8e7644fe-9f17-4fc3-8e4e-8b10a42d5d50

Lin, L.I.K. 1989. A concordance correlation coefficient to evaluate reproducibility. Biometrics 45 : 255-268. https://doi.org/10.2307/2532051.

Kupper, T., Bonjour, C., Achermann, B., Zaucker, F., Rihm, B., Nyfeler-Brunner, A.,Leuenberger, C., Menzi, H., 2010. Ammoniakemissionen in der Schweiz: Neu-berechung 1990-2007, Prognose bis 2020. Bundesamt für Umwelt, Bern.

Oosterlynck, Patrik, Steven De Saeger, An Leyssen, Sam Provoost, Arno Thomaes, Bart Vandevoorde, Jan Wouters, \& Desiré Paelinckx (2020). Criteria Voor De Beoordeling Van De Lokale Staat Van Instandhouding Van De Natura 2000 Habitattypen In Vlaanderen. Instituut voor Natuur- en Bosonderzoek, Brussel. DOI: doi.org/10.21436/inbor.14061248. https://pureportal. inbo.be/portal/files/18656674.

Payne, R.J., Campbell, C., Stevens, C.J., ... \& Dise, N.B. 2020. Disparities between plant community responses to nitrogen deposition and critical loads in UK semi-natural habitats. Atmospheric Environment 239: 117478.

Poikolainen, J., Piispanen, J., Karhu, J. \& Kubin, E. 2009. Long-term changes in nitrogen deposition in Finland (1990-2006) monitored using the moss Hylocomium splendens. Environmental Pollution 157: 3091-3097.

Rihm, B., Kurz, D., 2001. Deposition and critical loads of nitrogen in Switzerland.Water Air Soil Pollut. 130, 1223-1228.

Roth, T., Kohli, L., Rihm, B. \& Achermann, B. (2013). Nitrogen deposition is negatively related to species richness and species composition of vascular plants and bryophytes in Swiss mountain grassland. Agriculture, Ecosystems and Environment 178, 121-126.

Roth, T., Kohli, L., Rihm, B., Meier, R. \& Achermann, B. (2017). Using change-point models to estimate empirical critical loads for nitrogen in mountain ecosystems. Environmental Pollution 220, 1480-1487.

Rosén, K., Gundersen, P., Tegnhammar, L., Johansson, M. \& Frogner, T.1992. Nitrogen Enrichment of Nordic Forest Ecosystems: The Concept of Critical Loads. Ambio 21: 364-368.

Schaminée, J.H.J., Stortelder, A.H.F., Weeda, E.J. \& Westhoff, V. 1995-1998. De Vegetatie van Nederland, deel 1-4. Opulus, Uppsala/Leiden.

Schöpp W, Posch M, Mylona S, Johansson M, 2003. Long-term development of acid deposition (1880-2030) in sensitive freshwater regions in Europe. Hydrology and Earth System Sciences 7(4): 436-446; DOI: 10.5194/hess-7-436-2003

Simpson D, Benedictow A, Berge H, Bergström R, Emberson LD, Fagerli H, Flechard CR, Hayman GD, Gauss M, Jonson JE, Jenkin ME, Nyiri A, Richter C, Semeena VS, Tsyro S, Tuovinen J-P, Valdebenito A, Wind P, 2012. The EMEP MSC-W chemical transport model - technical description. Atmospheric Chemistry and Physics 12: 7825-7865; DOI: 10.5194/acp-12-7825-2012.

Simpson D, Andersson C, Christensen JH, Engardt M, Geels C, Nyiri A, Posch M, Soares J, Sofiev M, Wind $P$, Langner J, 2014. Impacts of climate and emission changes on nitrogen deposition in Europe: a multi-model study. Atmospheric Chemistry and Physics 14: 6995-7017; DOI: 10.5194/acp-14-6995-2014.

Smits, N. A. C., Mucher, C. A., Ozinga, W. A., de Waal, R. W., \& Wamelink, G. W. W. (2016). Procesindicatoren PAS: rapportage 2016. (Wageningen Environmental Research rapport; No. 2771). Wageningen: Wageningen Environmental Research. https://doi.org/10.18174/401546 Bijlage 1 sheet 5 .

Soons, M.B., M.M. Hefting, E. Dorland, L.P.M. Lamers, C. Versteeg \& R. Bobbink (2017). Nitrogen effects on plant species richness in herbaceous communities are more widespread and stronger than those of phosphorus. Biological Conservation 227, 390-397.

Southon, G.E., Field, C., Caporn, S.J.M., Britton, A.J., Power, S.A., 2013. Nitrogen deposition reduces plant diversity and alters ecosystem functioning: field-scale evidence from a nationwide survey of UK heathlands. Plos One 8(4), e59031.

Sparrius, L.B. 2011. Inland dunes in The Netherlands: soil, vegetation, nitrogen deposition and invasive species. Ph.D. thesis, University of Amsterdam. 165 pp.

Stevens, C.J., C. Duprè, E. Dorland, C. Gaudnik, D.J.G. Gowing, A. Bleeker, M.Diekmann, D. Alard, R. Bobbink, D. Fowler, E. Corcket, J.O. Mountford, V. Vandvik, P. A. Aarrestad, S. Muller, N.B. Dise 
(2010). Nitrogen deposition threatens species richness of grasslands across Europe. Environmental Pollution, 158, 2940-2945.

Stevens, C.J., P. Manning, L.J.L. van den Berg, M.C.C. de Graaf, G.W.W. Wamelink, A.W. Boxman, A. Bleeker, P. Vergeer, M. Arroniz-Crespo, J. Limpens, L.P.M. Lamers, R. Bobbink \& E. Dorland. 2011. Ecosystem responses to reduced and oxidised nitrogen inputs in European terrestrial habitats. Environmental Pollution 159: 665-676.

Stevens, C.J., C. Duprè, E. Dorland, C. Gaudnik, D.J.G. Gowing, A. Bleeker, M. Diekmann, D. Alard, R. Bobbink, D. Fowler, E. Corcket, J.O. Mountford, V. Vandvik, P. A. Aarrestad, S. Muller, N.B. Dise 2011a. The impact of nitrogen deposition on acid grasslands in the Atlantic region of Europe. Environmental Pollution 159, 2243-2250.

Stevens, C., C. Duprè, C. Gaudnik, E. Dorland, N. Dise, D. Gowing, A. Bleeker, D. Alard, R. Bobbink, D. Fowler, V. Vandvik, E. Corcket, J.O. Mountford, P. A. Aarrestad, S. Muller \& M. Diekmann 2011 b. Changes in species composition of European acid grasslands observed along a gradient of nitrogen deposition. Journal of Vegetation Science 22, 207-215.

Tsyro S, Aas W, Solberg S, Benedictow A, Fagerli H, Posch M, 2018. Chapter 2: Status of transboundary air pollution in 2016. In: Fagerli $\mathrm{H}$, et al. (eds): Transboundary particulate matter, photo-oxidants, acidifying and eutrophying components. EMEP Status Report 1/2018, Norwegian Meteorological Institute, Oslo, Norway, pp.15-40; ISSN 1504-6109 (print); www.emep.int/mscw

Tsyro S, Aas W, Solberg S, Benedictow A, Fagerli H, Scheuschner T, 2019. Chapter 2: Status of transboundary air pollution in 2017. In: Fagerli H, et al. (eds): EMEP Status Report 1/2019, Norwegian Meteorological Institute, Oslo, Norway, pp.17-42; ISSN 1504-6109 (print); www.emep.int/mscw

Van den Berg, L.J.L., Vergeer, P., Rich, T.C.G., Smart, S.M., Guest, D. \& Ashmore, M.R. (2011). Direct and indirect effects of nitrogen deposition on species composition change in calcareous grasslands. Global Change Biology 17, 1871-1883.

Van Dobben, H.F, E.P.A.G. Schouwenberg, J. P. Mol, H.J.J. Wieggers, M.J.M. Jansen, J. Kros \& W. de Vries. 2004. Simulation of critical loads for nitrogen for terrestrial plant communities in The Netherlands. Alterra-rapport 953. Alterra, Wageningen.

Van Dobben, H. \& van Hinsberg, A. 2008. Overzicht van kritische depositiewaarden voor stikstof, toegepast op habitattypen en Natura 2000-gebieden. Alterra rapport 1654. Alterra, Wageningen.

Van Dobben, H.F., R. Bobbink, D. Bal \& A. van Hinsberg (2012). Overzicht van kritische depositiewaarden voor stikstof, toegepast op habitattypen en leefgebieden van Natura 2000. Alterra-rapport 2397, Wageningen.

Van Dobben, H.F., Posch, M., Wamelink, G.W.W., Hettelingh, J.P. \& De Vries, W. 2015. Plant species diversity indicators for use in the computation of critical loads and dynamic risk assessments. In: de Vries W., Hettelingh J-P., Posch M. (eds). Critical Loads and Dynamic Risk Assessments: Nitrogen, Acidity and Metals in Terrestrial and Aquatic Ecosystems. Springer, Dordrecht, Netherlands, pp. 59-81

Van Dobben, H.F., Wamelink, G.W.W., Slim, P.A. Kamiński, J. \& Piórkowski, H. 2017. Species-rich grassland can persist under nitrogen-rich but phosphorus-limited conditions. Plant Soil 411: 451-466. https://doi.org/10.1007/s11104-016-3021-z.

Van Dobben, H.F., Quik, C., Wamelink, G.W.W. \& Lantinga ET. 2019. Vegetation composition of Lolium perenne-dominated grasslands under organic and convential farming. Basic and Applied Ecology, 36, 45-53. https://doi.org/10.1016/j.baae.2019.03.002.

VSN International (2020). GenStat for Windows 21st Edition. VSN International, Hemel Hempstead, UK. https://www.vsni.co.uk/software/genstat.

Wamelink, G.W.W., C.J.F. ter Braak and H.F. van Dobben. 2003. Changes in large-scale patterns of plant biodiversity predicted from environmental. Landscape Ecology 18: 513-527.

Wamelink, W., Van Dobben, H. F., Goedhart, P. W. \& Jones-Walters, L. M. 2018. The Role of Abiotic Soil Parameters as a Factor in the Success of Invasive Plant Species. Emerging Science Journal. 2: 308-365.

Wamelink, G.W.W., J.P. Mol-Dijkstra, G.J. Reinds, J.C. Voogd, L.T.C. Bonten, M. Posch, S.M. Hennekens, W. De Vries. 2020. Prediction of plant species occurrence as affected by nitrogen deposition and climate change on a European scale. Environ. Pollut. 266: 115-257. https://doi.org/10.1016/j.envpol.2020.115257.

Wilkins, K. \& J. Aherne (2016). Vegetation community change in Atlantic oak woodlands along a nitrogen deposition gradient. Environmental Pollution 216, 115-124. 


\section{Bijlage 1 Data Leveranciers uit de EVA- database}

De onderstaande opnamensets uit de EVA-database zijn gebruikt voor dit onderzoek. Alle eigenaren zijn coauteur van dit onderzoek. Veel databases hebben een inschrijving in de 'Global Index of Vegetation-Opname Databases' (GIVD, www.givd.info). Per database wordt het aantal opnamen dat gebruikt is gegeven $(\mathrm{N})$.

\begin{tabular}{|c|c|c|c|}
\hline \multirow[t]{2}{*}{ GIVD code } & (GIVD) database naam & Eigenaar & $\mathbf{N}$ \\
\hline & Coastal database Borja Jiménez-Alfaro & Borja Jiménez-Alfaro & 49 \\
\hline EU-00-016 & Mediterranean Ammophiletea database & Corrado Marcenò & 48 \\
\hline EU-AT-001 & Austrian Vegetation Database & Wolfgang Willner & 6331 \\
\hline \multirow[t]{2}{*}{ EU-00-011 } & $\begin{array}{l}\text { Vegetation-Opname Database of the University of the } \\
\text { Basque Country (BIOVEG) }\end{array}$ & Idoia Biurrun & 5204 \\
\hline & GVRD_Bogs & Ute Jandt & 1328 \\
\hline EU-GB-001 & UK National Vegetation Classification Database & John S. Rodwell & 21036 \\
\hline EU-00-026 & CircumMed Pine Forest database & Gianmaria Bonari & 6 \\
\hline EU-CZ-001 & Czech National Phytosociological Database & Milan Chytrý & 253 \\
\hline EU-DK-002 & National Vegetation Database of Denmark & Jesper Erenskjold Moeslund & 106850 \\
\hline EU-00-027 & European Boreal Forest Vegetation Database & Anni Kanerva Jašková & 513 \\
\hline \multirow[t]{2}{*}{ EU-00-017 } & European Coastal Vegetation Database-A & John Janssen & 13 \\
\hline & European Coastal Vegetation Database-B & Corrado Marcenò & 38 \\
\hline EU-00-022 & European Mire Vegetation Database & Tomáš Peterka & 306 \\
\hline EU-00-022 & European Mire Vegetation Database & Tomáš Peterka & 133 \\
\hline \multirow[t]{3}{*}{ EU-00-028 } & European Weed Vegetation Database & Filip Küzmič & 1361 \\
\hline & European calcareous fens & Borja Jiménez-Alfaro & 664 \\
\hline & Finnish_National_Forest_Inventory & Päivi Merilä & 1727 \\
\hline \multirow[t]{3}{*}{ EU-FR-003 } & SOPHY & Emmanuel Garbolino & 72330 \\
\hline & French National Forest Inventory & $\begin{array}{l}\text { https://inventaire- } \\
\text { forestier.ign.fr/spip.php?rubrique149 }\end{array}$ & 26142 \\
\hline & GVRD_grasslands & Ute Jandt & 10820 \\
\hline EU-DE-014 & German Vegetation Reference Database (GVRD) & Ute Jandt & 25299 \\
\hline EU-DE-013 & VegetWeb Germany & Florian Jansen & 14321 \\
\hline EU-DE-013 & VegetWeb Germany & Friedemann Goral & 4266 \\
\hline EU-DE-013 & VegetWeb Germany & Friedemann Goral & 454 \\
\hline EU-DE-001 & VegMV & Florian Jansen & 2118 \\
\hline EU-DE-020 & German Grassland Vegetation Database (GrassVeg.DE) & Ricarda Pätsch & 5101 \\
\hline EU-00-025 & Gravel bar vegetation database & Veronika Kalníková & 12 \\
\hline EU-HU-003 & CoenoDat Hungarian Phytosociological Database & János Csiky & 1 \\
\hline EU-BE-002 & INBOVEG & Els De Bie & 6645 \\
\hline \multirow[t]{2}{*}{ EU-IE-001 } & Irish Vegetation Database & Úna FitzPatrick & 16916 \\
\hline & Masaryk University Database & Milan Chytrý & 3 \\
\hline EU-NL-001 & Dutch National Vegetation Database & Stephan Hennekens & 124999 \\
\hline EU-NL-003 & Dutch Military Ranges Vegetation Database (DUMIRA) & Iris de Ronde & 9161 \\
\hline EU-00-018 & The Nordic Vegetation Database & Jonathan Lenoir & 2506 \\
\hline \multirow[t]{2}{*}{ EU-00-002 } & Nordic-Baltic Grassland Vegetation Database (NBGVD) & Jürgen Dengler & 511 \\
\hline & Nordicforests Aune & Jonathan Lenoir & 41 \\
\hline \multirow[t]{3}{*}{ EU-PL-001 } & Polish Vegetation Database & Zygmunt Kącki & 18 \\
\hline & Portugal - Estela database & Jan Jansen & 2 \\
\hline & SalineVDB & Daniel Dítě & 147 \\
\hline EU-DE-040 & Database Schleswig-Holstein (Northern Germany) & Joachim Schrautzer & 1131 \\
\hline EU-SK-001 & Slovak Vegetation Database & Milan Valachovič & 72 \\
\hline EU-00-004 & $\begin{array}{l}\text { Iberian and Macaronesian Vegetation Information System } \\
\text { (SIVIM) }\end{array}$ & Xavier Font & 13 \\
\hline
\end{tabular}




\begin{tabular}{llllr} 
GIVD code & (GIVD) database naam & Eigenaar & N \\
EU-00-004 & $\begin{array}{l}\text { Iberian and Macaronesian Vegetation Information System } \\
\text { (SIVIM) }\end{array}$ & Xavier Font & 26 \\
\hline EU-00-004 & $\begin{array}{l}\text { Iberian and Macaronesian Vegetation Information System } \\
\text { (SIVIM) }\end{array}$ & Borja Jiménez-Alfaro & 1 \\
\hline EU-00-023 & $\begin{array}{l}\text { Iberian and Macaronesian Vegetation Information System } \\
\text { (SIVIM) - Deciduous Forests }\end{array}$ & Juan Antonio Campos & 229 \\
\hline EU-00-004 & $\begin{array}{l}\text { Iberian and Macaronesian Vegetation Information System } \\
\text { (SIVIM) }\end{array}$ & Maria Pilar Rodríguez-Rojo & 335 \\
\hline EU-00-004 & $\begin{array}{l}\text { Iberian and Macaronesian Vegetation Information System } \\
\text { (SIVIM) }\end{array}$ & Federico Fernández-González & 68 \\
\hline EU-ES-001 & $\begin{array}{l}\text { Iberian and Macaronesian Vegetation Information System } \\
\text { (SIVIM) - Wetlands }\end{array}$ & Aaron Pérez-Haase & 477 \\
\hline & Swedish_National_Forest_Inventory & https://www.slu.se/nfi & 14259 \\
\hline EU-CH-011 & $\begin{array}{l}\text { Monitoring Effectiveness of Habitat Conservation in } \\
\text { Switzerland }\end{array}$ & Ariel Bergamini & 970 \\
\hline EU-CH-005 & Swiss Forest Vegetation Database & Thomas Wohlgemuth & 1408 \\
\hline & Switzerland grassland database & Unknown & 640 \\
\hline EU-GB-004 & UK Floodplain Meadows Database & Irina Tatarenko & 26265 \\
\hline EU-UA-005 & Halophytic and coastal vegetation database of Ukraine & Tetiana Dziuba & 1 \\
\hline & & &
\end{tabular}




\section{Bijlage 2 Indeling van habitattypen in structuurtypen en ruwheid}

\begin{tabular}{|c|c|c|c|c|}
\hline Habitattype & Code & Structuurtype 1 & Structuurtype 2 & Ruwheid \\
\hline Zilte pionierbegroeiingen (zeekraal) & $1310-\mathrm{A}$ & zout & & laag \\
\hline Zilte pionierbegroeiingen (zeevetmuur) & $1310-B$ & zout & & laag \\
\hline Slijkgrasvelden & 1320 & zout & & laag \\
\hline Schorren en zilte graslanden (buitendijks) & $1330-\mathrm{A}$ & zout & & laag \\
\hline Schorren en zilte graslanden (binnendijks) & $1330-B$ & zout & & laag \\
\hline Embryonale duinen & 2110 & zout & & laag \\
\hline Witte duinen & 2120 & droog grasland & & laag \\
\hline Grijze duinen (kalkrijk) & $2130-A$ & droog grasland & & laag \\
\hline Grijze duinen (kalkarm) & $2130-B$ & droog grasland & & laag \\
\hline Grijze duinen (heischraal) & $2130-C$ & droog grasland & & laag \\
\hline Duinheiden met kraaihei (vochtig) & $2140-A$ & nat dwergstruweel & & laag \\
\hline Duinheiden met kraaihei (droog) & $2140-B$ & droog dwergstruweel & & laag \\
\hline Duinheiden met struikhei & 2150 & droog dwergstruweel & & laag \\
\hline Duindoornstruwelen & 2160 & droog struweel & & hoog \\
\hline Kruipwilgstruwelen & 2170 & nat dwergstruweel & & laag \\
\hline Duinbossen (droog) & $2180-A$ & droog loofbos & & hoog \\
\hline Duinbossen (vochtig) & $2180-B$ & nat loofbos & & hoog \\
\hline Duinbossen (binnenduinrand) & $2180-C$ & droog loofbos & & hoog \\
\hline Vochtige duinvalleien (open water) & $2190-A$ & water & & laag \\
\hline Vochtige duinvalleien (kalkrijk) & $2190-B$ & nat grasland & & laag \\
\hline Vochtige duinvalleien (ontkalkt) & $2190-C$ & nat grasland & & laag \\
\hline Stuifzandheiden met struikhei & 2310 & droog dwergstruweel & & laag \\
\hline Binnenlandse kraaiheibegroeiingen & 2320 & droog dwergstruweel & & laag \\
\hline Zandverstuivingen & 2330 & droog grasland & & laag \\
\hline Zeer zwakgebufferde vennen & 3110 & water & & laag \\
\hline Zwakgebufferde vennen & 3130 & water & & laag \\
\hline Kranswierwateren & 3140 & water & & laag \\
\hline Meren met krabbenscheer en fonteinkruiden & 3150 & water & & laag \\
\hline Zure vennen & 3160 & water & & laag \\
\hline Vochtige heiden (hogere zandgronden) & $4010-A$ & nat dwergstruweel & & laag \\
\hline Vochtige heiden (laagveengebied) & $4010-B$ & nat dwergstruweel & & laag \\
\hline Droge heiden & 4030 & droog dwergstruweel & & laag \\
\hline Jeneverbesstruwelen & 5130 & droog struweel & & hoog \\
\hline Pionierbegroeiingen op rotsbodem & 6110 & droog grasland & & laag \\
\hline Stroomdalgraslanden & 6120 & droog grasland & & laag \\
\hline Zinkweiden & 6130 & droog grasland & & laag \\
\hline Kalkgraslanden & 6210 & droog grasland & & laag \\
\hline Heischrale graslanden & 6230 & droog grasland & & laag \\
\hline Blauwgraslanden & 6410 & nat grasland & & laag \\
\hline Ruigten en zomen (droge bosranden) & $6430-\mathrm{C}$ & droog loofbos & & hoog \\
\hline Glanshaver- en vossenstaarthooilanden (glanshaver) & $6510-A$ & droog grasland & & laag \\
\hline Glanshaver- en vossenstaarthooilanden (grote vossenstaart) & $6510-B$ & droog grasland & & laag \\
\hline Actieve hoogvenen (hoogveenlandschap) & $7110-\mathrm{A}$ & nat dwergstruweel & moeras & laag \\
\hline Actieve hoogvenen (heideveentjes) & 7110-B & nat dwergstruweel & moeras & laag \\
\hline Herstellende hoogvenen & 7120 & nat dwergstruweel & moeras & laag \\
\hline Overgangs- en trilvenen (trilvenen) & $7140-\mathrm{A}$ & moeras & & laag \\
\hline Overgangs- en trilvenen (veenmosrietlanden) & 7140-B & moeras & & laag \\
\hline Pioniervegetaties met snavelbiezen & 7150 & moeras & & laag \\
\hline Galigaanmoerassen & 7210 & moeras & & laag \\
\hline Kalktufbronnen & 7220 & nat loofbos & & hoog \\
\hline Kalkmoerassen & 7230 & nat grasland & & laag \\
\hline Veldbies-beukenbossen & 9110 & droog loofbos & & hoog \\
\hline
\end{tabular}




\begin{tabular}{|c|c|c|c|c|}
\hline Habitattype & Code & Structuurtype 1 & Structuurtype 2 & Ruwheid \\
\hline Beuken-eikenbossen met hulst & 9120 & droog loofbos & & hoog \\
\hline Eiken-haagbeukenbossen (hogere zandgronden) & 9160-A & nat loofbos & & hoog \\
\hline Eiken-haagbeukenbossen (heuvelland) & $9160-B$ & droog loofbos & & hoog \\
\hline Oude eikenbossen & 9190 & droog loofbos & & hoog \\
\hline Hoogveenbossen & 91D0 & nat loofbos & & hoog \\
\hline Vochtige alluviale bossen (zachthoutooibossen) & 91E0-A & nat loofbos & & hoog \\
\hline Vochtige alluviale bossen (essen-iepenbossen) & 91E0-B & nat loofbos & & hoog \\
\hline Vochtige alluviale bossen (beekbegeleidende bossen) & $91 \mathrm{E} 0-\mathrm{C}$ & nat loofbos & & hoog \\
\hline Droge hardhoutooibossen & 91F0 & droog loofbos & & hoog \\
\hline
\end{tabular}




\section{Bijlage 3 Koppeling van EUNIS-typen aan structuurtypen en ruwheid}

\begin{tabular}{|c|c|c|c|c|}
\hline Code & EUNIS-omschrijving & Structuurtype 1 & Structuurtype 2 & Ruwheid \\
\hline C & Surface waters & water & & laag \\
\hline C11a & $\begin{array}{l}\text { Permanent oligotrophic waterbody with very soft-water } \\
\text { species }\end{array}$ & water & & laag \\
\hline C11b & $\begin{array}{l}\text { Permanent oligotrophic to mesotrophic waterbody with } \\
\text { soft-water species }\end{array}$ & water & & laag \\
\hline $\mathrm{C} 12 \mathrm{a}$ & $\begin{array}{l}\text { Permanent oligotrophic to mesotrophic waterbody with } \\
\text { Characeae }\end{array}$ & water & & laag \\
\hline $\mathrm{C} 12 \mathrm{~b}$ & Mesotrophic to eutrophic waterbody with vascular plants & water & & laag \\
\hline C14 & Permanent dystrophic waterbody & water & & laag \\
\hline $\mathrm{C} 15$ & Permanent inland saline and brackish waterbody & zout & & laag \\
\hline $\mathrm{C} 21 \mathrm{a}$ & Base-poor spring and spring brook & stromend water & & laag \\
\hline $\mathrm{C} 21 \mathrm{~b}$ & Calcareous spring and spring brook & stromend water & & laag \\
\hline $\mathrm{C} 22 \mathrm{~b}$ & $\begin{array}{l}\text { Permanent non-tidal, fast, turbulent watercourse of } \\
\text { plains and montane regions with Ranunculus spp. }\end{array}$ & stromend water & & laag \\
\hline $\mathrm{C} 23$ & Permanent non-tidal, smooth-flowing watercourse & stromend water & & laag \\
\hline $\mathrm{C} 24$ & Tidal river, upstream from the estuary & stromend water & & laag \\
\hline $\mathrm{C} 25 \mathrm{a}$ & Temperate temporary running watercourse & stromend water & & laag \\
\hline C35a & $\begin{array}{l}\text { Periodically exposed shore with stable, eutrophic } \\
\text { sediments with pioneer or ephemeral vegetation }\end{array}$ & moeras & & laag \\
\hline C35b & $\begin{array}{l}\text { Periodically exposed shore with stable, mesotrophic } \\
\text { sediments with pioneer or ephemeral vegetation }\end{array}$ & moeras & & laag \\
\hline $\mathrm{C} 35 \mathrm{c}$ & $\begin{array}{l}\text { Periodically exposed saline shore with pioneer or } \\
\text { ephemeral vegetation }\end{array}$ & zout & & laag \\
\hline $\mathrm{H} 32 \mathrm{~b}$ & geen beschrijving beschikbaar & droog grasland & & laag \\
\hline H32c & geen beschrijving beschikbaar & droog grasland & & laag \\
\hline MA & Coastal saltmarshes & zout & & laag \\
\hline MA221 & Atlantic saltmarsh driftline & zout & & laag \\
\hline MA222 & Atlantic upper saltmarsh & zout & & laag \\
\hline MA223 & $\begin{array}{l}\text { Atlantic upper-mid saltmarsh and saline and brackish } \\
\text { reed, rush and sedge bed }\end{array}$ & zout & & laag \\
\hline MA224 & Atlantic mid-low saltmarsh & zout & & laag \\
\hline MA225 & Atlantic pioneer saltmarsh & zout & & laag \\
\hline MA232 & Baltic coastal meadow & zout & & laag \\
\hline N11 & Atlantic, Baltic and Arctic sand beach & zout & & laag \\
\hline N13 & Atlantic and Baltic shifting coastal dune & droog grasland & & laag \\
\hline N15 & Atlantic and Baltic coastal dune grassland (grey dune) & droog grasland & & laag \\
\hline N18 & Atlantic and Baltic coastal Empetrum heath & droog dwergstruweel & & laag \\
\hline N19 & Atlantic coastal Calluna and Ulex heath & droog dwergstruweel & & laag \\
\hline N1A & Atlantic and Baltic coastal dune scrub & droog struweel & & laag \\
\hline N1D & Atlantic and Baltic broad-leaved coastal dune forest & droog loofbos & & hoog \\
\hline $\mathrm{N} 1 \mathrm{H}$ & Atlantic and Baltic moist and wet dune slack & nat grasland & moeras & laag \\
\hline N21 & Atlantic, Baltic and Arctic coastal shingle beach & zout & & laag \\
\hline N31 & Atlantic and Baltic rocky sea cliff and shore & zout & & laag \\
\hline N34 & Atlantic and Baltic soft sea cliff & zout & & laag \\
\hline Q11 & Raised bog & nat dwergstruweel & moeras & laag \\
\hline Q12 & Blanket bog & nat dwergstruweel & moeras & laag \\
\hline Q21 & Oceanic valley mire & nat dwergstruweel & & laag \\
\hline Q22 & Poor fen & moeras & & laag \\
\hline Q24 & Intermediate fen and soft-water spring mire & moeras & & laag \\
\hline Q25 & Non-calcareous quaking mire & moeras & & laag \\
\hline Q3 & Palsa and polygon mires & nat dwergstruweel & & laag \\
\hline Q41 & $\begin{array}{l}\text { Alkaline, calcareous, carbonate-rich small-sedge spring } \\
\text { fen }\end{array}$ & nat grasland & & laag \\
\hline
\end{tabular}




\begin{tabular}{|c|c|c|c|c|}
\hline Code & EUNIS-omschrijving & Structuurtype 1 & Structuurtype 2 & Ruwheid \\
\hline Q42 & Extremely rich moss-sedge fen & moeras & & laag \\
\hline Q43 & Tall-sedge base-rich fen & nat grasland & & laag \\
\hline Q44 & Calcareous quaking mire & moeras & & laag \\
\hline Q45 & Arctic-alpine rich fen & moeras & & laag \\
\hline Q51 & Tall-helophyte bed & moeras & & laag \\
\hline Q52 & Small-helophyte bed & moeras & & laag \\
\hline Q53 & Tall-sedge bed & moeras & & laag \\
\hline Q54 & Inland saline or brackish helophyte bed & zout & & laag \\
\hline Qa & Mires & nat dwergstruweel & & laag \\
\hline $\mathrm{Qb}$ & Wetlands & nat dwergstruweel & & laag \\
\hline $\mathrm{R}$ & Grasslands & $\begin{array}{l}\text { nat en droog } \\
\text { grasland }\end{array}$ & & laag \\
\hline R13 & $\begin{array}{l}\text { Cryptogam- and annual-dominated vegetation on } \\
\text { calcareous and ultramafic rock outcrops }\end{array}$ & droog grasland & & laag \\
\hline R1A & $\begin{array}{l}\text { Semi-dry perennial calcareous grassland (meadow } \\
\text { steppe) }\end{array}$ & droog grasland & & laag \\
\hline R1M & $\begin{array}{l}\text { Lowland to montane, dry to mesic grassland usually } \\
\text { dominated by Nardus stricta }\end{array}$ & droog grasland & & laag \\
\hline R1P & $\begin{array}{l}\text { Oceanic to subcontinental inland sand grassland on dry } \\
\text { acid and neutral soils }\end{array}$ & droog grasland & & laag \\
\hline R1Q & Inland sanddrift and dune with siliceous grassland & droog grasland & & laag \\
\hline R1R & $\begin{array}{l}\text { Mediterranean to Atlantic open, dry, acid and neutral } \\
\text { grassland }\end{array}$ & droog grasland & & laag \\
\hline R1S & Heavy-metal grassland in Western and Central Europe & droog grasland & & laag \\
\hline R21 & Mesic permanent pasture of lowlands and mountains & droog grasland & & laag \\
\hline R22 & Low and medium altitude hay meadow & droog grasland & & laag \\
\hline R35 & Moist or wet mesotrophic to eutrophic hay meadow & nat grasland & & laag \\
\hline R36 & Moist or wet mesotrophic to eutrophic pasture & nat grasland & & laag \\
\hline R37 & $\begin{array}{l}\text { Temperate and boreal moist or wet oligotrophic } \\
\text { grassland }\end{array}$ & nat grasland & & laag \\
\hline R42 & Boreal and Arctic acidophilous alpine grassland & droog grasland & & laag \\
\hline R51 & Thermophilous forest fringe of base-rich soils & droog loofbos & & hoog \\
\hline R52 & Forest fringe of acidic nutrient-poor soils & droog loofbos & & hoog \\
\hline R54 & Pteridium aquilinum vegetation & droog loofbos & & laag \\
\hline R55 & Lowland moist or wet tall-herb and fern fringe & moeras & & laag \\
\hline R57 & Herbaceous forest clearing vegetation & droog loofbos & & laag \\
\hline R63 & Temperate inland salt marsh & zout & & laag \\
\hline S11 & Shrub tundra & droog dwergstruweel & & laag \\
\hline $\mathrm{S} 12$ & Moss and lichen tundra & droog dwergstruweel & & laag \\
\hline S21 & Subarctic and alpine dwarf Salix scrub & nat dwergstruweel & & laag \\
\hline S22 & Alpine and subalpine ericoid heath & droog dwergstruweel & & laag \\
\hline $\mathrm{S} 23$ & Alpine and subalpine Juniperus scrub & droog struweel & & hoog \\
\hline S31 & $\begin{array}{l}\text { Lowland to montane temperate and submediterranean } \\
\text { Juniperus scrub }\end{array}$ & droog struweel & & hoog \\
\hline S32 & Temperate Rubus scrub & droog loofbos & & hoog \\
\hline S33 & $\begin{array}{l}\text { Lowland to montane temperate and submediterranean } \\
\text { genistoid scrub }\end{array}$ & droog struweel & & hoog \\
\hline S35 & Temperate and submediterranean thorn scrub & droog struweel & & hoog \\
\hline S37 & Corylus avellana scrub & droog loofbos & & hoog \\
\hline S38 & Temperate forest clearing scrub & droog loofbos & & hoog \\
\hline S41 & Wet heath & nat dwergstruweel & & laag \\
\hline S42 & Dry heath & droog dwergstruweel & & laag \\
\hline S91 & Temperate riparian scrub & nat loofbos & & hoog \\
\hline S92 & Salix fen scrub & nat loofbos & & hoog \\
\hline Sa & Scrub & struweel & & hoog \\
\hline $\mathrm{Sb}$ & Dwarf-shrub vegetation & droog dwergstruweel & & laag \\
\hline T11 & Temperate Salix and Populus riparian forest & nat loofbos & & hoog \\
\hline T12 & $\begin{array}{l}\text { Alnus glutinosa-Alnus incana forest on riparian and } \\
\text { mineral soils }\end{array}$ & nat loofbos & & hoog \\
\hline
\end{tabular}




\begin{tabular}{|c|c|c|c|c|}
\hline Code & EUNIS-omschrijving & Structuurtype 1 & Structuurtype 2 & Ruwheid \\
\hline T13 & Temperate hardwood riparian forest & nat loofbos & & hoog \\
\hline T14 & Mediterranean and Macaronesian riparian forest & nat loofbos & & hoog \\
\hline T16 & Broadleaved mire forest on acid peat & nat loofbos & & hoog \\
\hline T17 & Fagus forest on non-acid soils & droog loofbos & & hoog \\
\hline T19 & $\begin{array}{l}\text { Temperate and submediterranean thermophilous } \\
\text { deciduous forest }\end{array}$ & droog loofbos & & hoog \\
\hline T1B & Acidophilous Quercus forest & droog loofbos & & hoog \\
\hline $\mathrm{T} 1 \mathrm{C}$ & $\begin{array}{l}\text { Temperate and boreal mountain Betula and Populus } \\
\text { tremula forest on mineral soils }\end{array}$ & droog loofbos & & hoog \\
\hline T1G & Alnus cordata forest & droog loofbos & & hoog \\
\hline $\mathrm{T} 1 \mathrm{H}$ & $\begin{array}{l}\text { Broadleaved deciduous plantation of non site-native } \\
\text { trees }\end{array}$ & droog loofbos & & hoog \\
\hline T27 & Ilex aquifolium forest & droog loofbos & & hoog \\
\hline T29 & $\begin{array}{l}\text { Broadleaved evergreen plantation of non site-native } \\
\text { trees }\end{array}$ & droog loofbos & & hoog \\
\hline T3C & Taxus baccata forest & droog loofbos & & hoog \\
\hline U & Inland sparsely vegetated & droog grasland & & laag \\
\hline U23 & Temperate, lowland to montane siliceous scree & droog grasland & & laag \\
\hline V39 & Mesic perennial anthropogenic herbaceous vegetation & droog loofbos & & hoog \\
\hline
\end{tabular}




\section{Bijlage 4 EUNIS-typen waarvoor de vertaling naar structuurtype niet eenduidig is}

\begin{tabular}{|c|c|c|c|}
\hline EUNIS & EUNIS_src & Structuur & \#opnamen \\
\hline$A 25 c$ & new & $?$ & 2 \\
\hline$A 25 c$ & old & zout & 98 \\
\hline $\mathrm{C} 14$ & new & water & 38 \\
\hline $\mathrm{C} 14$ & old & $?$ & 1 \\
\hline C16b & new & $?$ & 134 \\
\hline $\mathrm{C} 16 \mathrm{~b}$ & old & water & 25 \\
\hline $\mathrm{C} 22 \mathrm{a}$ & new & $?$ & 176 \\
\hline $\mathrm{C} 22 \mathrm{a}$ & old & stromend water & 11 \\
\hline C24 & new & stromend water & 69 \\
\hline $\mathrm{C} 24$ & old & $?$ & 3 \\
\hline $\mathrm{C} 35 \mathrm{c}$ & new & zout & 59 \\
\hline $\mathrm{C} 35 \mathrm{c}$ & old & $?$ & 1 \\
\hline C35d & new & $?$ & 32 \\
\hline C35d & old & moeras & 27 \\
\hline $\mathrm{H}$ & new & $?$ & 42 \\
\hline $\mathrm{H}$ & old & droog grasland & 186 \\
\hline $\mathrm{H} 21$ & new & $?$ & 3 \\
\hline $\mathrm{H} 21$ & old & droog grasland & 13334 \\
\hline $\mathrm{H} 25$ & new & $?$ & 21 \\
\hline $\mathrm{H} 25$ & old & droog grasland & 101 \\
\hline $\mathrm{H} 26 \mathrm{a}$ & new & $?$ & 22 \\
\hline $\mathrm{H} 26 \mathrm{a}$ & old & droog grasland & 143 \\
\hline I1 & new & $?$ & 1 \\
\hline I1 & old & droog grasland & 22 \\
\hline IE51 & new & $?$ & 23 \\
\hline IE51 & old & droog grasland & 735 \\
\hline
\end{tabular}




\section{Bijlage 5 Afleiding van de dataset voor een soort}

Voor alle soorten in een habitat(sub)type is een dataset afgeleid die specifiek is voor het bij het habitat(sub)type behorende structuurtype. Stel bijvoorbeeld dat habitattype $\mathrm{H}$ behoort tot structuurtypen S1 en S2 en dat soort A een kwalificerende soort is voor $\mathrm{H}$. De afgeleide dataset voor soort A bevat dan allereerst alle enen van soort A in plots van structuurtypen S1 of S2. Het denkbeeldige verspreidingsgebied van soort A (in S1 en S2) wordt gevormd door de doorsnede van de cirkels van straal $25 \mathrm{~km}$ rond die plots. Aan de dataset worden vervolgens nullen toegevoegd voor die S1- of S2-plots binnen het denkbeeldige verspreidingsgebied. Tabel 15 geeft een hypothetisch voorbeeld met 12 opnamen: 6 opnamen van structuurtype S1 en 6 van S2. Veronderstel verder dat soort A behoort tot habitattype $\mathrm{H} 1$ van type $\mathrm{S} 1$, dat A ook behoort tot habitattype $\mathrm{H} 2$ van type $\mathrm{S} 2$, en tevens dat $A$ behoort tot habitattype $\mathrm{H} 3$ van type $\mathrm{S} 1$ en $\mathrm{S} 2$. De afstanden van de nulwaarnemingen tot de dichtstbijzijnde één-waarneming van S1 en S2 zijn gegeven door de Afstand-kolommen inclusief het minimum van deze twee afstanden. De procedure geeft dan de 0/1 data in Tabel 15 voor soort A in de drie habitattypen $\mathrm{H} 1, \mathrm{H} 2$ en $\mathrm{H} 3$.

Tabel 15 Constructie van datasets voor soort A behorende tot habitattype H1, H2 en H3, zie tekst.

\begin{tabular}{|c|c|c|c|c|c|c|c|c|}
\hline $\mathrm{Nr}$ & Struct & A & $\begin{array}{l}\text { Afstand } \\
\text { tot S1 }\end{array}$ & $\begin{array}{l}\text { Afstand } \\
\text { tot } 52\end{array}$ & $\begin{array}{l}\text { Afstand } \\
\text { Minimum }\end{array}$ & $\begin{array}{c}\text { Data H1 } \\
\text { (S1) }\end{array}$ & $\begin{array}{c}\text { data H2 } \\
\text { (S2) }\end{array}$ & $\begin{array}{c}\text { data H3 } \\
\text { (S1 en S2) }\end{array}$ \\
\hline 1 & $\mathrm{~S} 1$ & 1 & 0 & 10 & 0 & 1 & & 1 \\
\hline 3 & $\mathrm{~S} 1$ & 0 & 10 & 10 & 10 & 0 & & 0 \\
\hline 4 & $\mathrm{~S} 1$ & 0 & 10 & 100 & 10 & 0 & & 0 \\
\hline 6 & $\mathrm{~S} 1$ & 0 & 100 & 100 & 100 & & & \\
\hline 11 & $\mathrm{~S} 2$ & 1 & 10 & 0 & 0 & & 1 & 1 \\
\hline 12 & $\mathrm{~S} 2$ & 1 & 100 & 0 & 0 & & 1 & 1 \\
\hline 13 & $\mathrm{~S} 2$ & 0 & 10 & 10 & 10 & & 0 & 0 \\
\hline 14 & $\mathrm{~S} 2$ & 0 & 10 & 100 & 10 & & & 0 \\
\hline
\end{tabular}

Deze methode impliceert dat per soort waar nodig meerdere responscurven geschat moeten worden, namelijk specifiek voor het bij een habitattype behorende structuurtype. De soort Rhynchospora alba, (Witte snavelbies) komt bijvoorbeeld voor in de volgende vier habitattypen met bijbehorende structuurtypen tussen accolades:
1. 3160
Zure vennen
\{water\}
2. 7110-B Actieve hoogvenen (heideveentjes)
\{nat dwergstruweel, moeras
3. 7120
Herstellende hoogvenen
4. 7150
Pioniervegetaties met snavelbiezen
$\{$ nat dwergstruweel, moeras\}
\{moeras\}

Voor deze soort worden dus drie responscurven aangepast en wel voor de drie genoemde (combinaties van) structuurtypen. 


\section{Bijlage 6 Bilineaire Interpolatie}

Veronderstel dat een functiewaarde $f(\cdot)$ is gegeven op vier punten $\left(x_{1}, y_{1}\right),\left(x_{1}, y_{2}\right),\left(x_{2}, y_{1}\right)$ en $\left(x_{2}, y_{2}\right)$, op een rechthoekig grid. Bilineaire interpolatie kan dan gebruikt worden om de functiewaarde in een punt $(x, y)$ binnen de rechthoek te benaderen. De benadering gaat als volgt. Er wordt allereerst horizontaal lineair geïnterpoleerd in de $x$-richting, zowel voor $y_{1}$ als voor $y_{2}$ :

(1a) $\quad f\left(x, y_{1}\right) \approx(1-\lambda) f\left(x_{1}, y_{1}\right)+\lambda f\left(x_{2}, y_{1}\right)$

(1b) $\quad f\left(x, y_{2}\right) \approx(1-\lambda) f\left(x_{1}, y_{2}\right)+\lambda f\left(x_{2}, y_{2}\right)$

waarin $\lambda=\left(x-x_{1}\right) /\left(x_{2}-x_{1}\right)$

Vervolgens worden de zo verkregen functiewaarden lineair geïnterpoleerd in de $y$-richting:

(2)

$$
f(x, y) \approx(1-\mu) f\left(x, y_{1}\right)+\mu f\left(x, y_{2}\right)
$$

waarin $\mu=\left(y-y_{1}\right) /\left(y_{2}-y_{1}\right)$

Invullen van (1a) en (1b) in vergelijking (2) geeft het resultaat van de bilineaire interpolatie:

$$
f(x, y) \approx(1-\lambda)(1-\mu) f\left(x_{1}, y_{1}\right)+\lambda(1-\mu) f\left(x_{2}, y_{1}\right)+(1-\lambda) \mu f\left(x_{1}, y_{2}\right)+\lambda \mu f\left(x_{2}, y_{2}\right)
$$

Hetzelfde resultaat wordt verkregen door eerst te interpoleren in de $y$-richting en dan in de $x$-richting. Zie ook http://en.wikipedia.org/wiki/Bilinear_interpolation. 


\section{Bijlage 7 Onderbouwing van gemaakte keuzes bij het bepalen van de responscurven voor habitattypen}

Met name bij het schatten van responscurven voor habitattypen op basis van kwalificerende soorten zijn veel methodische keuzes gemaakt. In de hoofdtekst zijn die al aan de orde gekomen, maar in deze bijlage worden ze, vanwege het grote aantal en vanwege het feit dat er veel discussie over is gevoerd met de begeleidingscommissie, nog eens op een rijtje gezet en van een onderbouwing voorzien.

Voor welke habitattypen wordt een respons op stikstofdepositie geschat?

Responscurven worden geschat voor 61 in Nederland voorkomende habitattypen waarvoor de kritische depositiewaarde (KDW) beschikbaar is en die dus gevoelig zijn voor stikstofdepositie.

Welke gegevens worden gebruikt om de respons van habitattypen op de stikstofdepositie te bepalen? Vegetatieopnamen in de EVA-database met de daarbij behorende stikstofdepositie worden gebruikt voor het schatten van de responscurven voor habitattypen.

Onderbouwing: De EVA-database is de compleetste, systematisch opgezette database met vegetatieopnamen in Europa.

Hoe worden responscurven voor habitattypen bepaald op basis van kwalificerende soorten? De respons van een habitattype op stikstofdepositie wordt hier afgeleid van geschatte responscurven voor de bij het habitattype behorende kwalificerende soorten.

Onderbouwing: Het rechtstreeks schatten van responscurven voor habitattypen uit vegetatieopnamen is niet mogelijk, omdat er geen tool beschikbaar is om op Europese schaal vegetatieopnamen toe te kennen aan habitattypen.

Hoe zijn de soorten geselecteerd voor elk habitattype?

Voor elk habitattype is een lijst van zogenaamde kwalificerende soorten opgesteld op basis van de principes en de database achter 'De Vegetatie van Nederland'. Daarbij zijn twee criteria gehanteerd:

(1) het percentage voorkomen van een soort (presentie) en (2) de trouwgraad van een soort. Aan deze lijst zijn de typische soorten, indien niet al geselecteerd door de rekenregels, toegevoegd.

Onderbouwing: Kwalificerende soorten zijn soorten die planten-sociologisch bij een plantengemeenschap horen. Omdat habitattypen gedefinieerd worden op basis van (met name) plantengemeenschappen, kan op basis hiervan een lijst worden samengesteld van soorten die de goede kwaliteit indiceren.

Waarom worden de habitattypen onderverdeeld in structuurtypen?

Een deel van de plantensoorten komt in verschillende habitattypen voor. Omdat de responscurve voor een habitattype gebaseerd wordt op de responscurven van de bijbehorende kwalificerende soorten, is het van belang om de responscurve voor een soort zo veel mogelijk specifiek voor een habitattype te maken. Het is bijvoorbeeld wenselijk om aparte responscurven te schatten voor kraaihei in 'Duinheiden met kraaihei (vochtig)' en voor kraaihei in 'Vochtige duinvalleien (ontkalkt)'. Daartoe zouden alle vegetatieopnamen die gebruikt worden om de responscurven voor soorten te schatten, toegewezen moeten worden aan een habitattype. Op Europese schaal is het echter nog niet mogelijk om een koppeling te leggen tussen vegetatieopnamen en habitattype. Het is wel mogelijk om opnamen in te delen in elf zogenaamde vegetatiestructuurtypen en tevens de habitattypen in te delen in dezelfde structuurtypen. Op deze wijze kunnen voor soorten die in verschillende structuurtypen voorkomen afzonderlijke responscurven worden geschat per structuurtype.

Onderbouwing: De elf gekozen structuurtypen worden gekenmerkt door een combinatie van een bepaalde vegetatiestructuur en een bepaald vocht- en zoutgehalte van de bodem. Ze kunnen zowel 
gebruikt worden om de habitattypen in te delen, alsook de vegetatieopnamen in de EVA-database. Deze indeling is niet perfect, maar doet zo veel mogelijk recht aan de data. De indeling wordt flexibel gebruikt: sommige habitattypen zijn gekoppeld aan twee structuurtypen.

Welke vegetatieopnamen worden gebruikt?

Alle vegetatieopnamen in de EVA-database uit een voor dit onderzoek gedefinieerd selectiegebied zijn gebruikt. Dat selectiegebied omvat de zogenoemde Atlantische zone, aangevuld met de rest van Duitsland, de rest van Frankrijk, het noordoosten van Spanje, de lage delen van Oostenrijk en Zwitserland en Scandinavië (met uitzondering van het deel boven de poolcirkel). Opnamen boven $500 \mathrm{~m}$ hoogte en boven de poolcirkel worden niet gebruikt. Ook opnamen met een onbekende locatie of een onbekend jaar van opname worden niet gebruikt.

Onderbouwing: Dit is een groter gebied dan de Atlantische klimaatzone. Er is gekozen voor een groot gebied opdat ook voldoende informatie beschikbaar is over zeldzame soorten en lage stikstofdeposities. Het gekozen gebied heeft (klimatologische) omstandigheden die voldoende vergelijkbaar zijn met Nederland. Opnamen buiten het geselecteerde gebied liggen in duidelijk afwijkende klimaatzones. De locatie en het jaar van opname zijn beide nodig om de stikstofdepositie van de opnamen te kunnen bepalen alsmede de gemiddelde temperatuur en neerslag én het bodemtype.

\section{Welke jaren worden meegenomen?}

Alle vegetatieopnamen vanaf 1950 worden meegenomen.

Onderbouwing: Een grote range aan stikstofdeposities is wenselijk om de responscurven goed te kunnen schatten. Door ook vroege opnamen - dat wil zeggen vanaf 1950 - te gebruiken, worden meer opnamen met lage depositiewaarden geselecteerd. Dat heeft als potentieel nadeel dat de depositie in het (verre) verleden minder goed bekend is.

Hoe worden vegetatieopnamen ingedeeld in structuurtypen?

Habitat-specifieke responscurven voor de bij het habitattype behorende soorten zijn mogelijk door de koppeling 'habitattype $\longleftrightarrow$ structuurtype $\longleftrightarrow$ vegetatieopname'. Elke opname is eerst, op basis van expertregels, ingedeeld in een EUNIS-type en vervolgens, middels een vertaaltabel, in een structuurtype. Opnamen waaraan geen EUNIS-type kon worden toebedeeld, zijn niet gebruikt.

Onderbouwing: Andere indelingen van de opnamen in de EUNIS-typen zijn zeker mogelijk en ook de conversie naar structuurtypen is voor discussie vatbaar. In een vervolg zou het effect getest kunnen worden.

Hoe is de stikstofdepositie van een vegetatieopname bepaald?

Voor de stikstofdepositie zijn EMEP-gegevens op een grid van $5 \times 5 \mathrm{~km}$ gebruikt; deze zijn geïnterpoleerd naar de coördinaten van de opname. Vervolgens is het gemiddelde genomen van de deposities in het jaar van opname en de vier jaren daarvoor. De depositie is gecorrigeerd voor de ruwheidsfactor van de opname, waardoor hoge vegetaties zoals bossen ook een hogere depositie krijgen.

Onderbouwing: Sommige landen, zoals Nederland en Groot-Brittannië, hebben nauwkeurigere depositiekaarten. Deze zijn niet altijd eenvoudig beschikbaar en sluiten bovendien niet aan bij de landsgrenzen. Daarom is gekozen voor het uniforme modelmatige EMEP-programma. Een periode van vijf jaar is gekozen als compromis tussen het effect op langlevende soorten (zoals bomen) en op eenjarige soorten. Een wat langere of kortere tijdsperiode heeft waarschijnlijk een gering effect op de uitkomsten, aangezien naastliggende jaren een vergelijkbare depositie hebben. In plaats van een gemiddelde depositie over vijf jaar zou ook gewerkt kunnen worden met de depositiesom vanaf 1950. Dat zou wellicht theoretisch een betere maat zijn, maar hierover is nog niet veel bekend en het sluit ook niet aan bij de bestaande literatuur.

Welke aanvullende kenmerken van een opname worden gebruikt?

De gemiddelde temperatuur en de gemiddelde jaarlijkse neerslagsom over vijf jaar is geschat op basis van gegevens van weerstations in Europa. De vijf jaar betreffen opnieuw het jaar van opname en de vier jaren daarvoor. Het bodemtype van een opname is gebaseerd op de 'Soil Atlas of Europe'. Het daar gegeven bodemtype is verder vereenvoudigd tot klei (inclusief zout), zand (inclusief löss), veen, jonge bodems en water. Opnamen met bodemtypen menselijk en rotsig zijn verder niet gebruikt. 
Onderbouwing: Het PROPS-model gebruikt dezelfde weergegevens. De Soil Atlas of Europe is de best beschikbare bodemkaart op Europese schaal. Veel landen, waaronder Nederland, hebben gedetailleerdere bodemkaarten, maar deze zijn niet altijd goed vergelijkbaar. De gebruikte atlas lijkt verre van perfect, zo komen volgens de atlas in Nederland geen opnamen op löss voor. Opnamen met bodemtype menselijk zijn afgevallen, omdat zulke opnamen buiten het interessegebied liggen. Opnamen op bodemtypen rotsig zijn voor de Nederlandse habitattypen niet relevant en zijn daarom ook afgevallen.

Wat wordt precies verstaan onder een responscurve voor een soort?

Een responscurve voor een soort is een relatie tussen de kans op voorkomen van een soort en de stikstofdepositie, waarbij de relatie beschreven wordt door een wiskundige functie. Omdat de kans $\pi$ op voorkomen per definitie in het interval $(0,1)$ ligt, wordt vaak een logistische transformatie voor $\pi$ gebruikt. De meest simpele relatie is dan lineair, oftewel $\operatorname{logit}(\pi)=\alpha+\beta$ Ndep met parameters $\alpha$ en $\beta$. Onderbouwing: Een relatie op logistische schaal wordt veel gebruikt. Gebruikelijke curven zijn kwadratisch, met een optimum of een meer flexibele spline curve(n). De responscurve wordt met zogenaamde logistische regressie geschat uit 0/1-gegevens. Een rechtstreekse relatie tussen de kans op voorkomen en de stikstofdepositie negeert andere variabelen die ook van invloed kunnen zijn, zoals de zuurgraad en de grondwaterstand. Deze variabelen zijn lastig te verkrijgen op Europese schaal en worden daarom buiten beschouwing gelaten. Wel wordt er, in het schatten van de relatie, gecorrigeerd voor weergegevens en het bodemtype.

Wat is de geschatte relatie met stikstofdepositie?

Voor de relatie met stikstofdepositie wordt een zogenaamde smoothing spline met twee graden van vrijheid gebruikt.

Onderbouwing: Voor de relatie met stikstofdepositie zou een lineair of kwadratisch model gekozen kunnen worden. Een spline is echter flexibeler en wordt veel gebruikt in het modelleren van responscurven. Vanwege het zeer grote aantal waarnemingen geeft een spline met meer dan twee vrijheidsgraden in het algemeen een statistisch significant betere curve. Splines met meer vrijheidsgraden bewegen echter mee met mogelijk grote verschillen in kans op voorkomen bij naastliggende depositiewaarden, die veroorzaakt kunnen worden door bias in de gebruikte dataselectie. Daarom is gekozen voor een beperkt flexibele spline; deze zou een goed beeld moeten geven van het verloop van de respons over het gehele depositietraject.

Welke dataset wordt gebruikt voor het schatten van een responscurve voor een soort? De dataset voor een soort wordt gebaseerd op een geschat verspreidingsgebied van een soort. Dit gebied wordt gevormd door cirkels van $25 \mathrm{~km}$ rond opnamen waar de soort voorkomt, met als extra eis dat de opnamen moeten behoren tot het relevante structuurtype. De opnamen binnen dit gebied genereren een dataset met enen (opnamen waar de soort aanwezig is) en nullen (opnamen waar de soort afwezig is).

Onderbouwing: Het geschatte verspreidingsgebied voorkomt dat opnamen waar een soort van nature niet voorkomt, meegenomen worden. Er is gekozen voor een straal van $25 \mathrm{~km}$, omdat een veel grotere straal een te groot gebied lijkt te geven en met een veel kleinere straal soms nauwelijks opnamen worden geselecteerd waar een (zeldzame) soort niet voorkomt. De precieze waarde van de straal blijft enigszins arbitrair. Het gebruik van structuurtypen zorgt ervoor dat de geschatte responscurve specifieker is voor een structuurtype en dus ook voor een habitattype. Merk op dat zonder nulwaarnemingen geen responscurve voor de kans op voorkomen kan worden geschat.

Wordt er voor elke soort een responscurve geschat?

Er wordt alleen een curve geschat voor soorten met minimaal 100 opnamen waarin de soort aanwezig is.

Onderbouwing: Met weinig positieve waarnemingen wordt de responscurve met een te grote onzekerheid geschat. Bij een hogere grenswaarde dan 100 presenties vallen te veel zeldzame soorten af. Dat is onwenselijk, omdat dit onderzoek zich richt op de kwaliteit van habitattypen, die voor een belangrijk deel bestaat uit zeldzame soorten. Het minimale aantal van 100 is een compromis. 
Voor welke covariabelen wordt gecorrigeerd bij het schatten van de responscurven?

Er wordt gecorrigeerd voor temperatuur en neerslag én hun interactie, en tevens voor bodemtype.

Onderbouwing: Er zijn verschillende combinaties van de genoemde covariabelen vergeleken. De verschillen tussen de modellen ten aanzien van de relatie met stikstofdepositie, bleek daarbij gering te zijn, waarbij de verschillen vooral bepaald werden door het wel of niet corrigeren voor de weergegevens. $\mathrm{Er}$ is uiteindelijk gekozen voor het meest uitgebreide model. In een aanvullende analyse is ook gecorrigeerd voor verschillen tussen landen, om zo veronderstelde verschillen in bijvoorbeeld herstelbeheer te verdisconteren. Dat gaf echter onbegrepen resultaten en is daarom terzijde geschoven en verder niet onderzocht.

Voor welke covariabelen is niet gecorrigeerd bij het schatten van de responscurve?

De responscurve is niet gecorrigeerd voor onder andere beheer, historie, bodem-pH, beschikbaarheid van nutriënten en grondwaterstand.

Onderbouwing: Het is bekend dat bovengenoemde variabelen een (soms grote) invloed hebben op de mate van voorkomen van soorten. Toch zijn ze niet meegenomen, met name omdat de gegevens op Europese schaal ontbreken of omdat ze niet goed bepaald kunnen worden (zoals beheer). Dit is een negatieve keuze die uit nood is geboren. Idealiter wordt een multipele regressieanalyse uitgevoerd en daaruit komen de belangrijkste bepalende variabelen die als covariabelen worden geselecteerd. Dit is voor het PROPS-model wel op beperkte schaal gedaan en daaruit kwamen temperatuur en neerslag, $\mathrm{pH}$ en stikstofdepositie als belangrijkste naar voren. Alleen $\mathrm{pH}$ zit niet in het hier gebruikte model, maar pH en nutriëntenbeschikbaarheid worden mede bepaald door bodemtype, dat wél als covariabele wordt meegenomen. Het beheer is ook deels verdisconteerd in de habitattypen (en structuurtypen) zelf. Voor sommige habitattypen is immers een bepaalde vorm van beheer nodig om het type in stand te kunnen houden, bijvoorbeeld maaien en/of begrazing van graslanden. Het beheer binnen een habitattype kán echter behoorlijk variëren (met name het al dan niet toepassen van herstelmaatregelen in overbelaste situaties) en daarvoor kan niet worden gecorrigeerd.

Hoe wordt een responscurve verkregen alleen als functie van de depositie en niet van de covariabelen?

In het geschatte logistische regressiemodel worden de gemiddelde temperatuur en neerslagsom (over de laatste tien jaar in Nederland) ingevuld. Tevens wordt gewogen gemiddeld over de bodemtypen, naar rato van het voorkomen van de bodemtypen in Nederland.

Onderbouwing: Op deze wijze wordt een responscurve voor een soort verkregen die meer specifiek is voor de Nederlandse situatie. Daarna kunnen de covariabelen buiten beschouwing blijven.

Hoe wordt de responscurve voor een habitattype afgeleid uit de curven voor de bijbehorende soorten? De responscurven voor de soorten worden eerst genormaliseerd door te delen door het oppervlak onder de curve. Vervolgens worden de genormaliseerde curven gemiddeld tot de respons voor het habitattype. De gebruikte soortcurven zijn specifiek voor het habitattype via het structuurtype.

Onderbouwing: De som van de responscurven zelf geeft een schatting van het aantal aanwezige soorten als functie van de depositie. Algemene soorten, met een hoge kans op voorkomen, domineren echter de som, waardoor zeldzame soorten nauwelijks invloed hebben op de gesommeerde curve. De oppervlaktenormalisatie zorg ervoor dat de soorten een gelijk gewicht krijgen. De zogenaamde 'Habitat Suitability Index' (HSI) is een alternatieve normalisatie die regelmatig in de literatuur gebruikt wordt. Bij een test bleek dat de HSI algemene soorten zwaarder weegt dan de oppervlaktenormalisatie. Omdat we met name geïnteresseerd zijn in de zeldzame soorten, is de HSI niet gebruikt. Een gedegen vergelijking zou alsnog kunnen worden uitgevoerd.

Hoe wordt rekening gehouden met de range van stikstofdeposities in de data?

Voor elk structuurtype, en daarmee voor elk habitattype, is de relevante range van stikstofdeposities grofweg bepaald op basis van het $1 \%$ - en $99 \%$-percentiel van de soort-specifieke deposities. Deze range is ook gebruikt voor de oppervlaktenormalisatie.

Onderbouwing: Hiermee wordt voorkomen dat de responscurven worden geëxtrapoleerd naar stikstofdeposities waarvoor geen waarnemingen zijn. Extrapolatie kan een fout beeld geven van de respons. 
Wat is het belangrijkste bezwaar tegen de verkregen responscurven per habitattype?

De responscurven zijn uiteindelijk gebaseerd op het wel of niet voorkomen van soorten in de EVA-

database met vegetatieopnamen. Het is mogelijk, en misschien zelfs waarschijnlijk, dat deze database gevuld is met opnamen waarvoor 'selection bias' geldt. Immers, ecologen zijn geneigd om de vegetatie op te nemen op interessante plekken met een bijzondere soortensamenstelling. Daardoor kan het aantal zeldzame soorten in de database, en dus ook de responscurve, overschat worden en het aandeel algemene soorten wellicht onderschat worden. Dit beïnvloedt met name het niveau van de responscurve en wellicht minder de specifieke vorm van de curve. Dit bezwaar zou niet gelden indien de EVA-database een random steekproef van opnamen bevat, wellicht na stratificering. Daarnaast kunnen de gemaakte keuzes, zoals hierboven toegelicht, zelf ook weer tot (onbedoelde) bias leiden. In hoeverre hier sprake van is en of dat met deels andere keuzes verminderd kan worden, kon in de beschikbare tijd niet nader worden onderzocht. 


\title{
Bijlage 8 Responscurven voor habitattypen en onderliggende kwalificerende soorten per set van covariabelen
}

\author{
A. Responscurven voor habitattypen en onderliggende kwalificerende soorten per set van \\ covariabelen \\ Het zip bestand kwalsoortencovar.zip bevat in totaal 60 pdf-bestanden, namelijk één bestand per \\ habitat(sub)type met daarin op de eerste pagina de genormaliseerde responscurven voor het habitat, \\ gevolgd door genormaliseerde responscurven voor de bij het habitattype behorende kwalificerende \\ soorten. Op de $y$-as van elke grafiek staat steeds de genormaliseerde presentie en op de $x$-as de \\ stikstofdepositie (in $\mathrm{kg} / \mathrm{ha} / \mathrm{j}$.). Boven de responscurve voor het habitattype staat de habitatcodering, \\ de afkorting van het bijbehorende structuurtype en de beschrijving van het habitattype. Elke grafiek \\ bevat vier curven: \\ 1. X (rood) er is niet gecorrigeerd voor covariabelen; \\ 2. W (groen) er is gecorrigeerd voor temperatuur en neerslag en hun interactie; \\ 3. B (blauw) er is gecorrigeerd voor bodemtype; \\ 4. WB (zwart) er is gecorrigeerd voor temperatuur en neerslag en hun interactie én tevens voor \\ bodemtype. Dit is de uiteindelijke responscurve die in het rapport staat.
}

De responscurven gelden voor Nederland en zijn verkregen door, indien nodig, in het logistische regressiemodel de gemiddelde regenval en temperatuur in Nederland in te vullen en tevens gewogen te middelen over de bodemtypen.

In de figuur voor het habitattype is de KDW (Van Dobben et al., 2012) weergegeven als een verticale gestippelde zwarte lijn en de empirische kritische depositiewaarde (Bobbink \& Hettelingh, 2011; Van Dobben et al., 2012) als een grijs gekleurd vlak. Een empirische KDW is niet voor alle habitattypen beschikbaar.

Voor de soorten wordt langs de $y$-as eerst aangegeven of de soort een kwalificerende soort is $(K)$ of een kwalificerende verdringingssoort (KV) en dan de wetenschappelijk naam.

In de figuur wordt, in een regel bovenin, eerst voor Europa aangegeven hoeveel positieve opnamen er zijn (de enen) ten opzichte van het totaalaantal gebruikte opnamen (nullen en enen) alsmede het bijbehorende percentage positieve opnamen. Daarna volgen dezelfde waarden voor de Nederlandse (NL) opnamen. De Nederlandse opnamen vormen een deelverzameling van de Europese opnamen.

De bestandsnamen, zoals $91 D 0$ (01-Kwalific-NdepRuw-X-W-B-WB-2DF-25km).pdf, zijn opgebouwd uit de volgende elementen:

- de codering van het habitattype (91D0);

- het betreft data bestaande uit nullen en enen (01);

- de grafieken zijn voor de kwalificerende soorten (Kwalific);

- de stikstofdepositie is gecorrigeerd voor de ruwheidsfactor (NdepRuw);

- er zijn vier grafieken zoals hierboven aangegeven (X-W-B-WB);

- het aantal vrijheidsgraden voor de spline (2DF);

- de (cirkel)afstand van het geschatte verspreidingsgebied van een soort rond de opnamen waar de soort voorkomt $(25 \mathrm{~km})$. 


\section{B. Kwalificerende en verdringingssoorten per habitattype}

De file Kwalificerende soorten en verdringingssoorten.xIsx bevat voor 61 habitattypen, genoemd in Bijlage 3, de resulterende kwalificerende soorten. Deze zijn gecodeerd door een 1 indien de soort kwalificerend is en door een 2 indien het een kwalificerende soort betreft die tevens een verdringingssoort is. De soorten gecodeerd met een 3 zijn verdringingssoorten die niet kwalificerend zijn. In sheet 1 wordt de toekenning gegeven, daarnaast is er een sheet met uitleg.

\section{Aantal waarnemingen per soort-typecombinatie}

In de file 'aantal waarnemingen soort-type.xIsx' worden de aantallen presenties (vegetatieopnamen) per soort-structuurtypecombinatie gegeven. In sheet 1 staan de gegevens, daarnaast is er een sheet met uitleg. In roodtint is aangegeven welke combinaties minder dan 100 waarnemingen hebben en waarvoor geen curve is geschat. 


\section{Bijlage 9 Python-programma en procesrapport voor het koppelen van EVA-database met covariabelen}

Het Python-script voor het samenvoegen en selecteren van de vegetatieopnamen uit de EVA-database en de covariabelen is te vinden op https://git.wur.nl/roelo008/doren_2019 (mocht de directe link niet werken, dan graag deze link kopiëren en in de browser plakken). Hieronder is het procesrapport te vinden.

Processing report for DOREN created 20210113

Starting @ 202101131523 with 1356336 EVA headers containing 20483 unique species (based on column matched_concept after simplification).

Dropping duplicate PlotObservationsIDs going from 1356336 to 1356335

Applying requirements as follows:

Req 1: <latitude> is niet leeg -2 rows failed

Req 2: <longitude> is niet leeg -3 rows failed

Req 3: plot is in AOI W: \PROJECTS\Doren19\a_brondata \AOI\ne_50m_cntrs_AOI_diss_fin.shp - 503691 rows failed

Req 4: Altitude $<=500 \mathrm{~m}$ based on W: \PROJECTS\Doren19\a_brondata \covariables\DEM\DTM_3035.tif - 331766 rows failed

Req 8: <date_of_recording > is niet leeg - 114942 rows failed

Req 9: <date_of_recording> is jonger dan 1950 - 28714 rows failed

Req 10: plot has species inventory - 10 rows failed

Union between requirements req1, req2, req3, req4, req8, req9, req10 gives 719435 rows that DO NOT meet requirements. Remaining: 636900

Manual overwrite EUNIS type for 508 plots to 542 based on

W: \PROJECTS\Doren19\a_brondata\EVA\delivery_20210112\Calluna_Avenula.cSV

Manual overwrite EUNIS type for 1677 plots to S42 based on

W: \PROJECTS\Doren19\a_brondata\EVA \delivery_20210112\Calluna_Molinea.csv

Manual overwrite EUNIS type for 11 plots to $\mathrm{S} 42$ based on

W: \PROJECTS\Doren19\a_brondata\EVA\delivery_20210112\Empetrum_Avenula.csv

Manual overwrite EUNIS type for 25 plots to S42 based on

W: \PROJECTS\Doren19\a_brondata\EVA \delivery_20210112\Empetrum_Molinea.csv

Manual overwrite EUNIS type for 96 plots to S41 based on

W:\PROJECTS\Doren19\a_brondata\EVA\delivery_20210112\Erica_Avenula.csv

Manual overwrite EUNIS type for 1421 plots to S41 based on

W:\PROJECTS\Doren19\a_brondata\EVA \delivery_20210112\Erica_Molinea.csV

Read 1035 species requested for processing (source: "c: \Users\roelo008\Wageningen University \& Research \DOREN General\DOREN-2020-12-02.xIsx", sheet: "Soorten", column: "wetenschappelijke naam"). 
Simplyfing requested species names to non-subspecies with 988 remaining.

976 are matching with (simplified) species in DOREN EVA column matched_concept

12 not matching with (simplified) species in DOREN EVA column matched_concept

Aronia floribunda no alternatives found

Bidens cernua $\quad$ ['Bidens cernuus']

Blysmus rufus $\quad$ ['Blysmopsis rufa']

Calamagrostis $\times$ calammophila no alternatives found

Evernia prunastra no alternatives found

Festuca arundinacea ['Schedonorus arundinaceus']

Festuca brevipila ['Festuca stricta subsp. trachyphylla']

Helictotrichon pratensis no alternatives found

Nasturtium microphyllum/officinale no alternatives found

Placidium rufescens no alternatives found

Puccinellia pseudodistans no alternatives found

Scirpus lacustris ['Schoenoplectus lacustris']

Added Covariable country from ne_50m_cntrs_sel_buff_diss_2_3035.shp with 636799 plots remaining.

Added Covariable soil_type from WRBLEV1_laea.tif with 561080 plots remaining.

Added Covariable five_yearly_precip from w: \PROJECTS\Doren19\a_brondata\covariables\EObs\2_compiled with 530302 plots remaining.

Added Covariable five_yearly_temp from w:\PROJECTS\Doren19\a_brondata\covariables\EObs \2_compiled with 530302 plots remaining.

Adding doorvertaling van EUNIS type naar structuurtype.

EUNIS codes w/o doorvertaling naar vegtype:

0: H34

1: T1H-T35

2: R1F

3: F41-F42

4: G26

5: T21-T27

6: T3M

7: N16

8: R1E

9: S38-T11

10: S52-S53

11: R55-R57

12: S53-T3A

13: T36-T3M

14: S51 
15: S38-T16

16: T1E-T3M

17: T22

18: T17-T35

19: T17-T1F

20: V

21: S61-S73

22: R23

23: F91

24: S35-S38

25: T16-T3M

26: Т27-Т3А-Т3M

27: ТЗА-ТЗМ

28: T1A

29: E56

30: T1F-T3M

31: T1B-T3M

32: T1F-T27

33: T24

34: R43

35: R55-V39

36: S53-T1A

37: T1B-T1E

38: S31-S61

39: F31b-F91

40: S35-S52

41: Т3J-T3M

42: $\mathrm{H} 32 \mathrm{~d}$

43: T21-T3M

44: T17-T1E

45: N-Qa

46: T19-T22

47: S41-S92

48: S11-S41

49: T3K-Т3M

50: R56

51: V32

52: S32-S35 
53: T1H-T35-T3M

54: R36-R55

55: T3A

56: T37

57: S42-S61

58: R1B

59: N1B

60: U25

61: G12b-G18

62: S33-S35

63: T13-T1E

64: R54-S42

65: T13-T35

66: T3]

67: S11-S42

68: Fa

69: S53

70: V11

71: T17-T3M

72: T1E-T27

73: T1H-T27

74: R12

75: S32-S33

76: S26

77: T18-T27

78: S25-S92

79: T36

80: N-V

81: R44

82: S31-S35

83: H31c

84: T13-T27

85: T1B-T1D

86: S51-S52

87: T35-T3A

88: T31

89: T3K

90: S38-T1E 
91: S53-T36

92: T21

93: V14

94: H31a

95: S31-S32

96: S53-T21

97: R1E!-S61

98: T32-Т35

99: N

100: 536

101: T18-T35

102: T1H-T3M

103: F61a

104: MA253

105: S35-S91

106: T15-T1H

107: E41

108: T27-T3M

109: T27-T3C

110: G3A

111: R1D

112: T1E-T3C

113: S61-S65

114: E13a

115: S62

116: T12-T13

117: T1B-T35

118: S35-S92

119: S32-S92

120: T18-T1B

121: V12

122: U3D

123: S52-S61

124: N19-N1A

125: MA-N

126: S53-T1H

127: V38

128: G1Aa-G1Ab 
129: S31-S33

130: B34a

131: S52

132: S35-S53

133: R61

134: G3B

135: T15-T16

136: R1H

137: Q52-R55

138: V13

139: T1A-T22

140: T11-T12

141: $S 25$

142: F22a-F41-F42

143: S51-S73

144: T32

145: S32-S35-S38

146: R18

147: $\mathrm{Fb}$

148: V33

149: T19-T3M

150: 573

151: T35

152: T11-T1E

153: T35-Т3M

154: S38-T13

155: T22-T3A

156: V15

157: G31b

158: S25-S91

159: R11

160: T18-T3M

161: MA251

162: T1E-T1H

163: E52a

164: R31

165: IE28

166: N-R 
167: T1E-T3A

168: S35-S37

169: T12-T15

170: S74

171: V37

172: T1A-T3A

173: T27-T3A

174: R62

175: S65

176: T1B-T1E-T27

177: R55-V35

178: G3Da

179: S32-S38

180: T1E-T32

181: R21-R55

182: R16

183: C35e

184: R32

185: R56-C21a

186: S51-S61

187: N14

188: S25-S26

189: T19-T35

190: N-Qb

191: T12-T27

192: S32-S37

193: T37-T3M

194: T1B-T27

195: MA252

196: T15-T3M

197: F22a-F41

198: G3F2

199: R34

200: N1J

201: T18-T1E

202: S66

203: T1E-T35

204: T15-T18 
205: R22-R55

206: 593

207: S61-T24

208: F22a-F42

209: T12-T1E

210: 561

211: S31-S52

212: S61-S62

213: S11-S92

214: T1C!-T1C

215: T19-T1E

216: T13-Т3M

217: T1A-T21

218: R37-R55

219:

220: S53-T19

221: N32

De structuurtypes zijn:

moeras

nat loofbos

stromend water

droog struweel

nat dwergstruweel

zout

droog dwergstruweel

droog grasland

droog loofbos

nat grasland

water

Added NDep Single from POSCH: 513850 rows remaining.

Added NDep from POSCH with distinction open-forest: 513850 rows remaining.

Testing dataset integrity

country_label -- no missing data

soil_type_vals -- no missing data

soil_type_label -- no missing data

144 | Wageningen Environmental Research Rapport 3089 


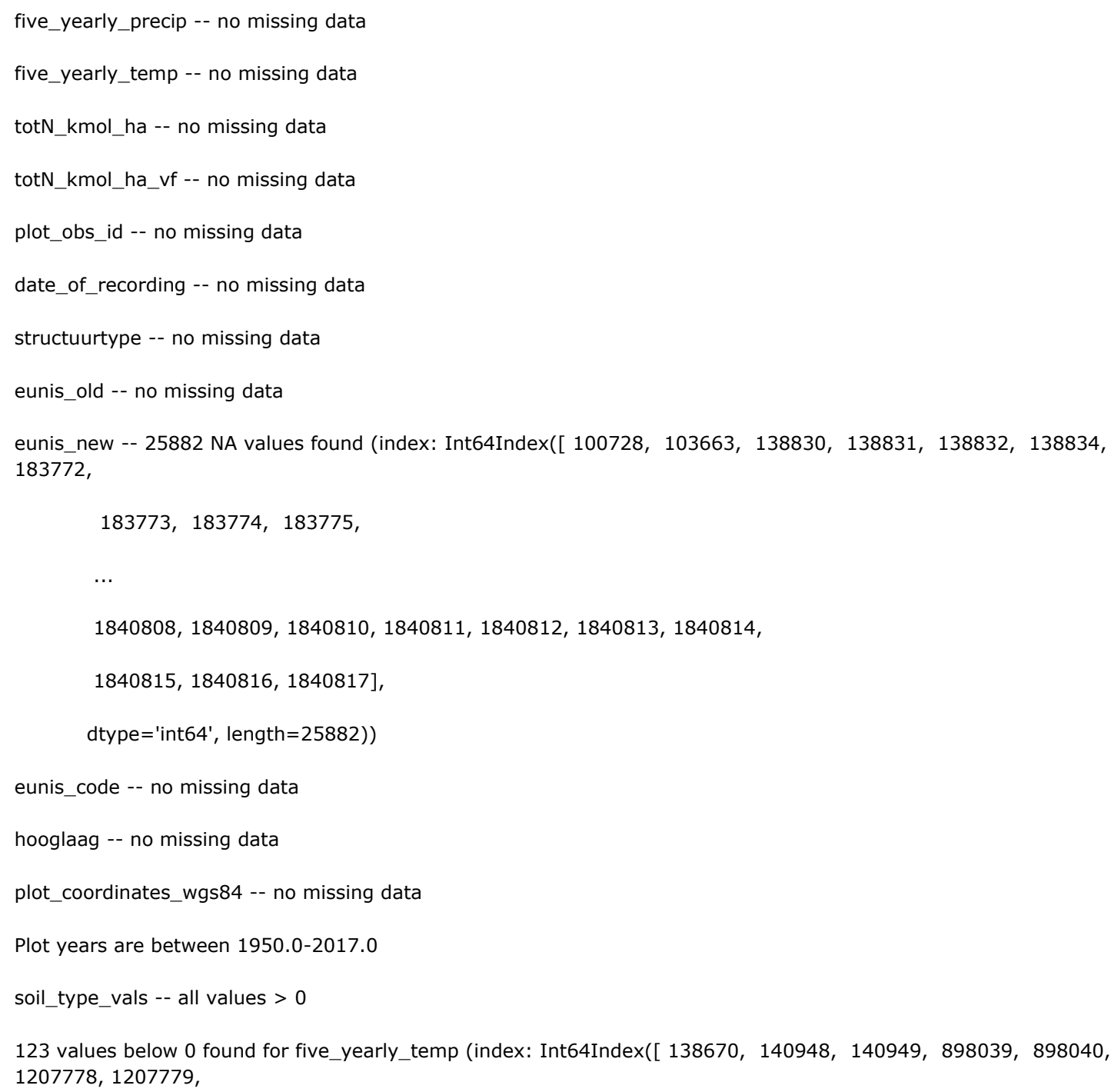




\begin{tabular}{|c|c|c|c|c|c|}
\hline A25c & $\begin{array}{l}2.0 \\
2\end{array}$ & & & & \\
\hline C14 & 1.0 & & & & 38.0 \\
\hline & 2 & & & & \\
\hline C16b & 134.0 & & & & 25.0 \\
\hline & 2 & & & & \\
\hline $\mathrm{C} 22 \mathrm{a}$ & 176.0 & & & 11.0 & \\
\hline & 2 & & & & \\
\hline C24 & 3.0 & & & 69.0 & \\
\hline & 2 & & & & \\
\hline C35c & 1.0 & & & & \\
\hline & 2 & & & & \\
\hline C35d & 32.0 & & 27.0 & & \\
\hline & 2 & & & & \\
\hline $\mathrm{H}$ & 42.0 & 186.0 & & & \\
\hline & 2 & & & & \\
\hline $\mathrm{H} 21$ & 3.0 & 13334.0 & & & \\
\hline & 2 & & & & \\
\hline $\mathrm{H} 25$ & 21.0 & 101.0 & & & \\
\hline & 2 & & & & \\
\hline $\mathrm{H} 26 \mathrm{a}$ & 22.0 & 143.0 & & & \\
\hline & 2 & & & & \\
\hline I1 & 1.0 & 22.0 & & & \\
\hline & 2 & & & & \\
\hline IE51 & 23.0 & 735.0 & & & \\
\hline & 2 & & & & \\
\hline
\end{tabular}

Alle NDep gegevens $>0$

Written plot covar output file: c: \Users\roelo008\OneDrive -

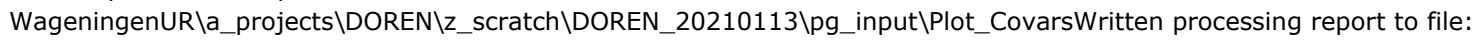
c: \Users \roelo008\OneDrive -

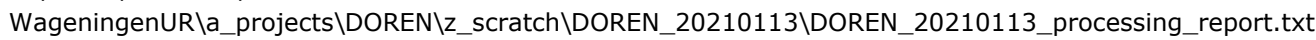

succes: Lysimachia vulgaris present in EVA database

Written single file output for species Lysimachia vulgaris to file:

./c_out/DOREN_20210113/pg_input/Lysimachia_vulgaris_NDep_Nearest succes: Lycopodium clavatum present in EVA database

Written single file output for species Lycopodium clavatum to file:

./c_out/DOREN_20210113/pg_input/Lycopodium_clavatum_NDep_Nearest succes: Palustriella commutata present in EVA database

Written single file output for species Palustriella commutata to file:

./C out/DOREN_20210113/pg_input/Palustriella_commutata_NDep_Nearest succes: Juncus balticus present in EVA database

Written single file output for species Juncus balticus to file:

./c_out/DOREN_20210113/pg_input/Juncus_balticus_NDep_Nearest fail: Festuca brevipila absent in EVA database

succes: Rumex acetosa present in EVA database

Written single file output for species Rumex acetosa to file:

./c_out/DOREN_20210113/pg_input/Rumex_acetosa_NDep_Nearest succes: Ranunculus acris present in EVA database

Written single file output for species Ranunculus acris to file:

./c_out/DOREN_20210113/pg_input/Ranunculus_acris_NDep_Nearest succes: Cytisus scoparius present in EVA database

Written single file output for species Cytisus scoparius to file:

./C_out/DOREN_20210113/pg_input/Cytisus_scoparius_NDep_Nearest succes: Sphagnum tenellum present in EVA database 
Written single file output for species Sphagnum tenellum to file:

./c_out/DOREN_20210113/pg_input/Sphagnum_tenellum_NDep_Nearest succes: Pastinaca sativa present in EVA database

Written single file output for species Pastinaca sativa to file:

./c_out/DOREN_20210113/pg_input/Pastinaca_sativa_NDep_Nearest succes: Epilobium montanum present in EVA database

Written single file output for species Epilobium montanum to file:

./c_out/DOREN_20210113/pg_input/Epilobium_montanum_NDep_Nearest succes: Bellis perennis present in EVA database

Written single file output for species Bellis perennis to file:

./c_out/DOREN_20210113/pg_input/Bellis_perennis_NDep_Nearest succes: Festuca rubra present in EVA database

Written single file output for species Festuca rubra to file:

./C_out/DOREN_20210113/pg_input/Festuca_rubra_NDep_Nearest succes: Circaea x intermedia present in EVA database

Written single file output for species Circaea $\mathrm{x}$ intermedia to file:

./c_out/DOREN_20210113/pg_input/Circaea_x_intermedia_NDep_Nearest succes: Phleum pratense present in EVA database

Written single file output for species Phleum pratense to file:

./c_out/DOREN_20210113/pg_input/Phleum_pratense_NDep_Nearest succes: Vaccinium oxycoccos present in EVA database

Written single file output for species Vaccinium oxycoccos to file:

./c_out/DOREN_20210113/pg_input/Vaccinium_oxycoccos_NDep_Nearest succes: Molinia caerulea present in EVA database

Written single file output for species Molinia caerulea to file:

./C_out/DOREN_20210113/pg_input/Molinia_caerulea_NDep_Nearest succes: Ranunculus sceleratus present in EVA

database

Written single file output for species Ranunculus sceleratus to file:

./c_out/DOREN_20210113/pg_input/Ranunculus_sceleratus_NDep_Nearest succes: Orchis anthropophora present in EVA database

Written single file output for species Orchis anthropophora to file:

./c_out/DOREN_20210113/pg_input/Orchis_anthropophora_NDep_NearestWritten processing report to file:

./c_out/DOREN_20210113/DOREN_20210113_processing_report.txt

Made with Python 3.5 using Pandas by Hans Roelofsen, WEnR team B\&B.

See git for source script: https://git.wur.nl/roelo008/doren_2019. 


\section{Bijlage 10 Genstat-programma voor het schatten van responscurven}

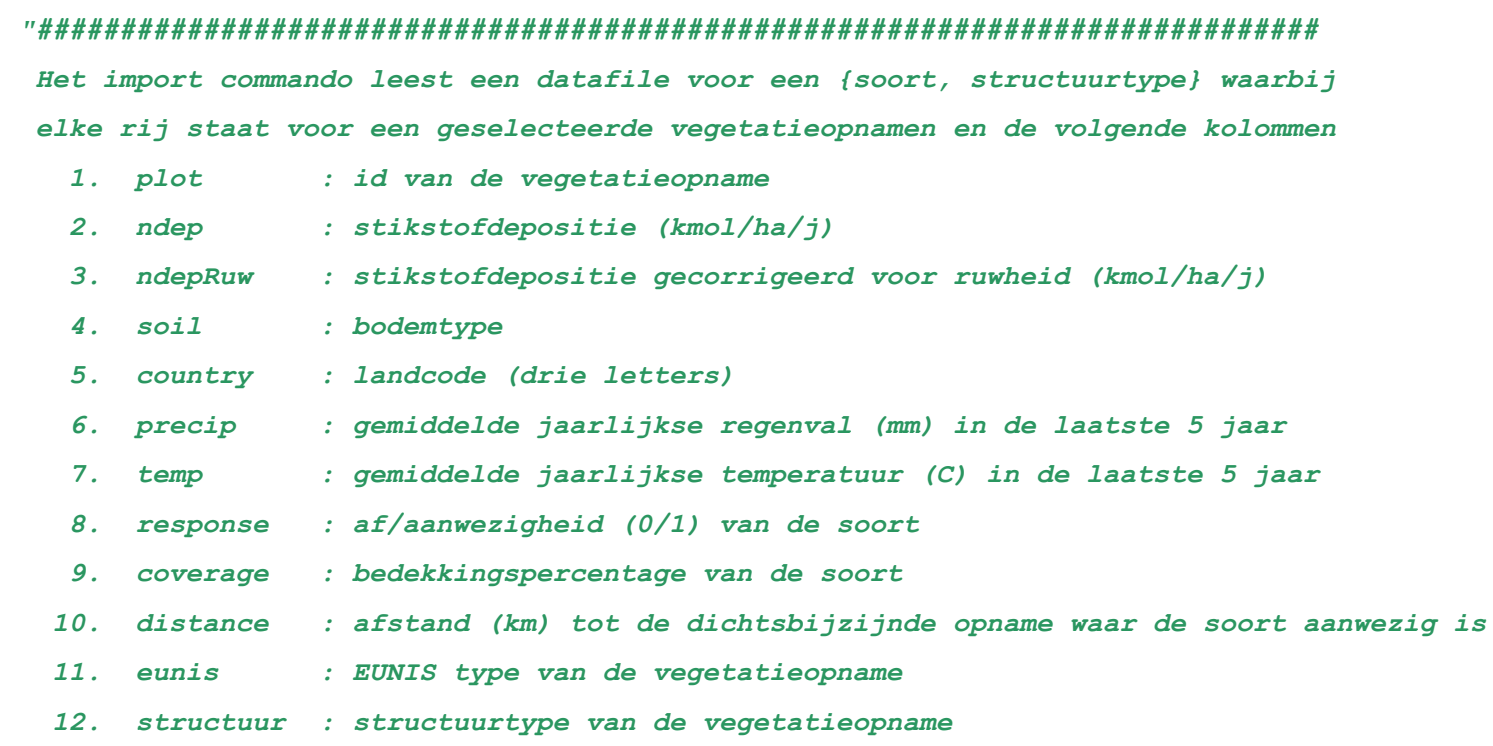

\#\#\#\#\#\#\#\#\#\#\#\#\#\#\#\#\#\#\#\#\#\#\#\#\#\#\#\#\#\#\#\#\#\#\#\#\#\#\#\#\#\#\#\#\#\#\#\#\#\#\#\#\#\#\#\#\#\#\#\#\#\#\#\#\#\#\#"

text dataFile; 'Abietinella_abietina\#droog grasland.csv'

text dataFile; 'Brachythecium_glareosum\#droog grasland.csv'

import dataFile; isave=isave

subset [plot.ne.C('*')] isave[]

calculate ndep, ndepRuw $=14 *$ ndep, ndepRuw

groups [redefine=yes] soil, country, eunis, structuur

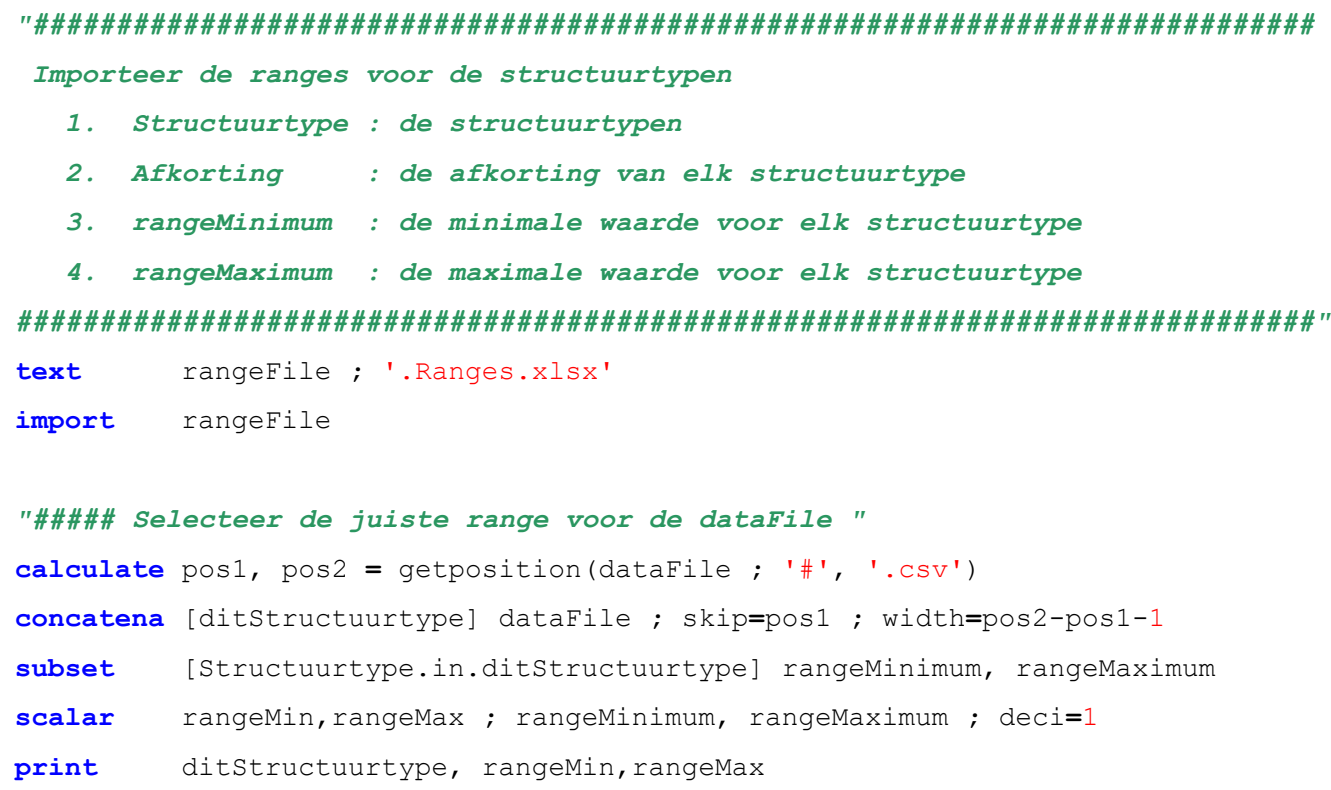

"\#\#\#\# Voeg een grid van stikstofdeposities toe waarvoor predicties worden berekend " "\#\#\#\# Doe dit voor elk voorkomend bodemtype; bereid ook het gewogen gemiddelde voor " scalar mis 


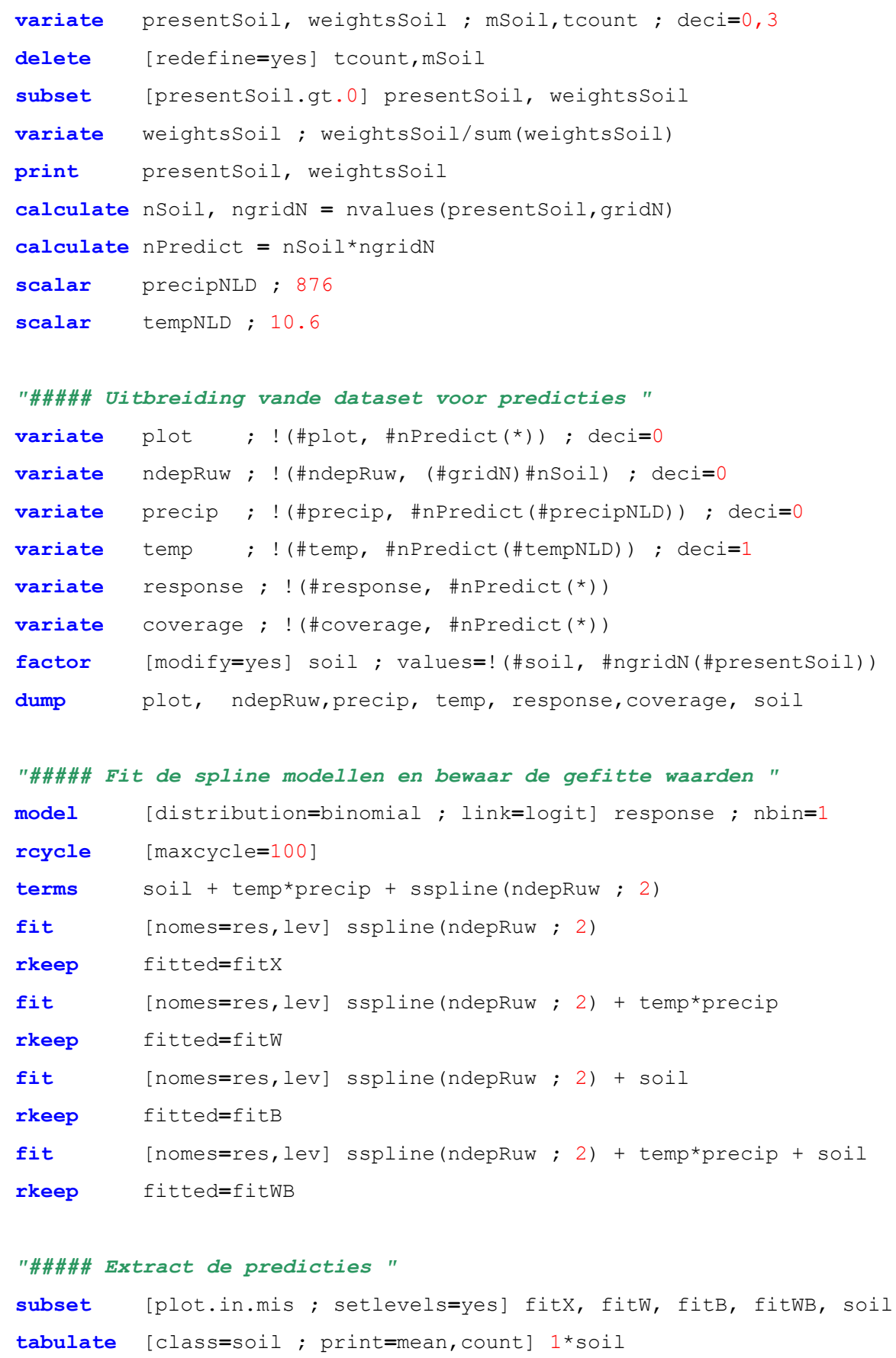


calculate uppery $=1.06 * \max (\operatorname{vmax}(\operatorname{lp}(\operatorname{normX}$, normW, normB, normWB $)))$

"\#\#\#\# Grafiek van genormaliseerde presenties"

fframe $\quad[$ rows=1; columns=1; rupper=0.5; xmlower=0.09; ymlower=0.07]

frame [grid=xy, yx] 1

pen $\quad-1,-3,-5 ;$ size $=0.8$

text colour ; t (red,green, blue, black)

pen $1 \ldots 4 ;$ symbols=0; method=line; linestyle=1; thick=2 ; colour=\#colour

pen $\quad 11 \ldots 14 ;$ symbols=0; method=line; linestyle=2; thick=2 ; colour=\#colour

yaxis 1 ; lower=0 ; upper=upperY ; title='Genormaliseerde presentie'

xaxis 1 ; lower=0 ; upper=max(gridN) ; marks=10; title='N depositie Ruw (kg/ha/j.)'

txreplace dataFile ; title ; oldsub=!t('\#') ; newsub=!t(' / ')

txreplace 2 (title) ; oldsub='.csv', '_' ; newsub=' ', ' '

restrict normX, normW, normB, normWB ; gridN.lt.rangeMin

dgraph [key=0; scr=keep ; title=title] normX, normW, normB, normWB ; gridN ; pen=11...14

restrict normX, normW, normB, normWB ; (gridN.ge.rangeMin).and.(gridN.le.rangeMax)

dgraph [key=0; scr=keep] normX, normW, normB, normWB ; gridN ; pen=1..4

restrict normX, normW, normB, normWB ; (gridN.gt.rangeMax) .and. (gridN.le.(rangeMax+14))

dgraph [key=0; scr=keep] normx, normW, normB, normWB ; gridN ; pen=11..14

restrict normX, normW, normB, normWB 
Wageningen Environmental Research Postbus 47

6700 AA Wageningen

T 0317480700

www.wur.nl/environmental-research

Wageningen Environmental Research Rapport 3089

ISSN 1566-7197
De missie van Wageningen University \& Research is 'To explore the potential of nature to improve the quality of life'. Binnen Wageningen University \& Research bundelen Wageningen University en gespecialiseerde onderzoeksinstituten van Stichting Wageningen Research hun krachten om bij te dragen aan de oplossing van belangrijke vragen in het domein van gezonde voeding en leefomgeving. Met ongeveer 30 vestigingen, 6.500 medewerkers ( $5.500 \mathrm{fte}$ ) en 12.500 studenten behoort Wageningen University \& Research wereldwijd tot de aansprekende kennisinstellingen binnen haar domein. De integrale benadering van de vraagstukken en de samenwerking tussen verschillende disciplines vormen het hart van de unieke Wageningen aanpak. 


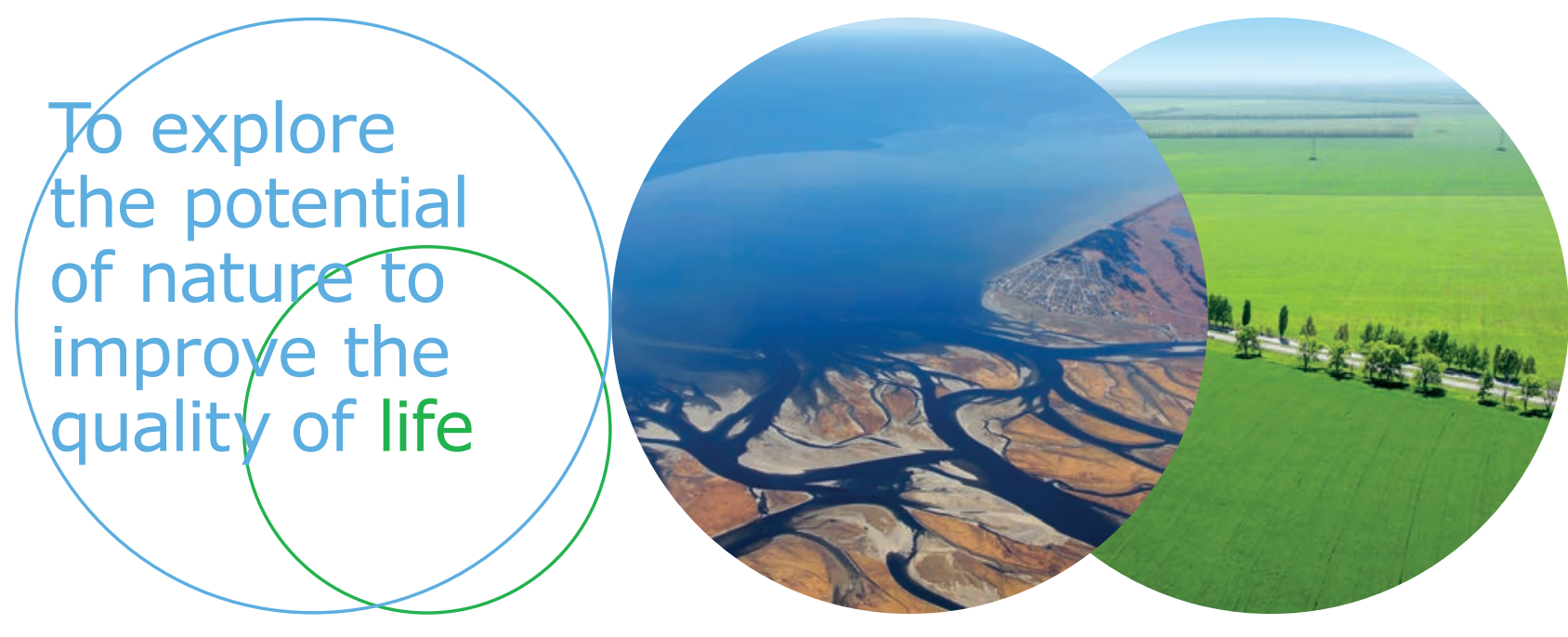

Wageningen Environmental Research Postbus 47

$6700 \mathrm{AB}$ Wageningen

T 317480700

www.wur.nl/environmental-research

Rapport 3089

ISSN 1566-7197
De missie van Wageningen University \& Research is 'To explore the potential of nature to improve the quality of life'. Binnen Wageningen University \& Research bundelen Wageningen University en gespecialiseerde onderzoeksinstituten van Stichting Wageningen Research hun krachten om bij te dragen aan de oplossing van belangrijke vragen in het domein van gezonde voeding en leefomgeving. Met ongeveer 30 vestigingen, 6.500 medewerkers ( $5.000 \mathrm{fte}$ ) en 12.500 studenten behoort Wageningen University \& Research wereldwijd tot de aansprekende kennisinstellingen binnen haar domein. De integrale benadering van de vraagstukken en de samenwerking tussen verschillende disciplines vormen het hart van de unieke Wageningen aanpak. 